\title{
resources
}

\section{Criticality of \\ the Rare Earth \\ Elements: Current and \\ Future Sources and Recycling}

Edited by

Simon M. Jowitt Printed Edition of the Special Issue Published in Resources 


\section{Criticality of the Rare Earth Elements: Current and Future Sources and Recycling}





\section{Criticality of the Rare Earth Elements: Current and Future Sources and Recycling}

Special Issue Editor

Simon M. Jowitt 
Special Issue Editor

Simon M. Jowitt

University of Nevada Las Vegas

USA

Editorial Office

MDPI

St. Alban-Anlage 66

Basel, Switzerland

This is a reprint of articles from the Special Issue published online in the open access journal Resources (ISSN 2079-9276) from 2017 to 2018 (available at: http:/ / www.mdpi.com/journal/resources/special_ issues/criticality_rare_earth_elements)

For citation purposes, cite each article independently as indicated on the article page online and as indicated below:

LastName, A.A.; LastName, B.B.; LastName, C.C. Article Title. Journal Name Year, Article Number, Page Range.

ISBN 978-3-03897-017-0 (Pbk)

ISBN 978-3-03897-018-7 (PDF)

Articles in this volume are Open Access and distributed under the Creative Commons Attribution (CC BY) license, which allows users to download, copy and build upon published articles even for commercial purposes, as long as the author and publisher are properly credited, which ensures maximum dissemination and a wider impact of our publications. The book taken as a whole is (c) 2018 MDPI, Basel, Switzerland, distributed under the terms and conditions of the Creative Commons license CC BY-NC-ND (http:/ / creativecommons.org/licenses/by-nc-nd/4.0/). 


\section{Contents}

About the Special Issue Editor $\ldots \ldots \ldots \ldots \ldots \ldots \ldots \ldots \ldots$

\section{Simon M. Jowitt}

Introduction to a Resources Special Issue on Criticality of the Rare Earth Elements:

Current and Future Sources and Recycling

Reprinted from: Resources 2018, 7,35, doi: 10.3390/resources7020035 . . . . . . . . . . . . . .

\section{Virginia T. McLemore}

Rare Earth Elements (REE) Deposits Associated with Great Plain Margin Deposits (Alkaline-Related), Southwestern United States and Eastern Mexico

Reprinted from: Resources 2018, 7, 8, doi: 10.3390/resources7010008

York R. Smith, Pankaj Kumar and John D. McLennan

On the Extraction of Rare Earth Elements from Geothermal Brines

Reprinted from: Resources 2017, 6, 39, doi: 10.3390/resources6030039

\section{Elizabeth J. Catlos and Nathan R. Miller}

Speculations Linking Monazite Compositions to Origin: Llallagua Tin Ore Deposit (Bolivia)

Reprinted from: Resources 2017, 6, 36, doi: 10.3390/resources6030036 . . . . . . . . . . . . 65

Wei Chen, Huang Honghui, Tian Bai and Shaoyong Jiang

Geochemistry of Monazite within Carbonatite Related REE Deposits

Reprinted from: Resources 2017, 6, 51, doi: 10.3390/resources6040051

\section{Jaroslav Dostal}

Rare Earth Element Deposits of Alkaline Igneous Rocks

Reprinted from: Resources 2017, 6, 34, doi: 10.3390/resources6030034

\section{Claire L. McLeod and Mark. P. S. Krekeler}

Sources of Extraterrestrial Rare Earth Elements: To the Moon and Beyond

Reprinted from: Resources 2017, 6, 40, doi: 10.3390/resources6030040

\section{Erika Machacek, Jessika Luth Richter and Ruth Lane}

Governance and Risk-Value Constructions in Closing Loops of Rare Earth Elements in Global Value Chains

Reprinted from: Resources 2017,6,59, doi: 10.3390/resources6040059 . . . . . . . . . . . . . 138 



\section{About the Special Issue Editor}

Simon M. Jowitt, Assistant Professor in Economic Geology, University of Las Vegas, Nevada, USA, was educated in the UK, acquiring a BSc (Hons) at the University of Edinburgh, an MSc at the Camborne School of Mines, and a PhD at the University of Leicester. Prior to taking up his current position he spent several years at Monash University in Australia working on various aspects of economic geology and igneous petrology, including the supply of critical metals. Simon's current research focuses on the use of geochemistry to unravel geological processes in a variety of settings with direct application to mineralising systems, igneous petrology, mineral exploration, global tectonics, and the links between magmatism and metallogeny. He has extensive expertise in mineral economics and the "economic" side of economic geology, and has several recent publications on global $\mathrm{Cu}, \mathrm{Ni}, \mathrm{Co}, \mathrm{Pb}-\mathrm{Zn}$, rare earth element, and indium resources. He was awarded the Society of Economic Geologists Lindgren Award in 2014 and IoM3 Mann Redmayne Medals in 2013 and 2016. 



\title{
Editorial
}

\section{Introduction to a Resources Special Issue on Criticality of the Rare Earth Elements: Current and Future Sources and Recycling}

\author{
Simon M. Jowitt \\ Department of Geoscience, University of Nevada Las Vegas, 4505 S. Maryland Parkway, Las Vegas, \\ NV 89154-4010, USA; simon.jowitt@unlv.edu; Tel.: +1-702-895-2447, Fax: +1-702-895-4064
}

Received: 14 May 2018; Accepted: 23 May 2018; Published: 26 May 2018

\begin{abstract}
The rare earth elements (REE) are vital to modern technologies and society and are amongst the most important of the critical elements. This special issue of Resources examines a number of facets of these critical elements, current and future sources of the REE, the mineralogy of the REE, and the economics of the REE sector. These papers not only provide insights into a wide variety of aspects of the REE, but also highlight the number of different areas of research that need to be undertaken to ensure sustainable and secure supplies of these critical metals into the future.
\end{abstract}

Keywords: rare earth elements; criticality; critical metals; mineralogy; mineral economics

The rare earth elements (REE) are amongst the most important of the critical elements and have a wide variety of uses (Table 1) within the civilian, energy, and military sectors of the economy. These elements are defined by the International Union of Applied and Pure Chemistry (IUPAC) as the 15 lanthanide elements plus Sc and Y (Table 1) [1]. They have similar electron configurations but also have very distinctive physical and chemical properties that are ideally suited to their usage in a wide variety of technologies and industrial applications. The REE enable or enhance certain magnetic, luminescence, and strength characteristics within end-products, all of which are derived from their partially occupied $4 \mathrm{f}$ electron orbitals [2]. This means these elements have low substitutability and as such are crucial to a wide variety of modern and high technologies in a range of different sectors (Table 1).

Table 1. Common uses of the rare earth elements.

\begin{tabular}{crcr}
\hline Element & Common Uses & Medium-Term Supply Risk & Long-Term Supply Risk \\
\hline $\mathrm{La}$ & Optics, batteries, catalysis & 46.5 \\
$\mathrm{Ce}$ & Chemical applications, coloring, catalysis & 64.2 & 44.0 \\
$\mathrm{Pr}$ & Magnets, lighting, optics & 63.3 & 49.2 \\
$\mathrm{Nd}$ & Magnets, lighting, lasers, optics & 65.1 & 47.5 \\
$\mathrm{Pm}$ & Limited use due to radioactivity, used in paint and atomic & $\mathrm{N}$ & $\mathrm{N} / \mathrm{A}$ \\
$\mathrm{Sm}$ & batteries; very rare in nature & $\mathrm{N} / \mathrm{A}$ & 45.4 \\
$\mathrm{Eu}$ & Magnets, lasers, masers & 63.8 & 48.1 \\
$\mathrm{Gd}$ & Lasers, color TV, lighting, medical applications & 64.7 & 47.9 \\
$\mathrm{~Tb}$ & Magnets, glassware, lasers, X-ray generation, computer & 64.7 & 47.9 \\
$\mathrm{Dy}$ & applications, medical applications & 64.7 & 47.1 \\
$\mathrm{Ho}$ & Lasers, lighting & 64.4 & 47.2 \\
$\mathrm{Er}$ & Magnets, lasers & 64.4 & 48.2 \\
$\mathrm{Tm}$ & Lasers & 64.8 & 46.2 \\
$\mathrm{Yb}$ & Lasers, steelmaking & 64.1 & 46.2 \\
$\mathrm{Lu}$ & X-ray generation & 64.1 & 45.7 \\
$\mathrm{Sc}$ & Lasers, chemical industry applications & N/A \\
$\mathrm{Y}$ & Medical applications, chemical industry applications & $\mathrm{N} / \mathrm{A}$ & 42.1 \\
\hline
\end{tabular}

Adapted from Weng et al. [3] with supply risk scores (out of 100, where 100 is the highest possible risk) from Nasser et al. [4]. N/A = Not available. 
The increase in the number of uses of the REE has also led to a coincident increase in demand for these elements [3]. However, although abundant REE resources have been identified to date [3], it is unclear how many of these resources will be converted into reserves and production. This uncertainty reflects a wide variety of aspects such as challenges over the processing of REE ores and the presence of deleterious elements, such as Th, two of several factors that both currently and in the future may result in some REE resources (e.g., within heavy mineral sands [5]) not being utilized. Social and environmental issues and the uncertainties over the economics of the REE sector of the economy [6], among others, also contribute to the uncertainties over REE resources. The majority of REE demand is met by primary production from mines, dominantly within China (e.g., Bayan Obo). This dominance of supply from one country is an important factor in the criticality of the REE. One factor relating to this heavy reliance on the primary production of the REE is the balance problem, where the primary production is dominated by La and Ce but the majority of REE demand is for Nd or Dy [7,8]. This issue could be overcome by the recycling of REE-bearing end-products that predominantly contain $\mathrm{Nd}$ and Dy rather than other less-in-demand REE. However, currently less than 1\% of the REE within end-products are currently recycled [9]. This lack of recycling reflects the fact that the amount of the REE used in end-products spans several orders of magnitude ( $<\mathrm{mg}$ to several $\mathrm{kg}$ [10]). In addition, the recycling of the REE is hampered by the complexity of the uses of these elements, the difficulties involved in chemically separating the REE into individual elements, and the long lifetime of some of the uses of the REE, among other reasons [9].

All of this means that more needs to be known about the REE in order to ensure that secure and sustainable supplies of these critical elements are available long into the future. The papers within this special issue provide a number of new insights into different aspects of the geology of the REE, the processes that concentrate these critical elements, the potential for the extraction of these elements from unconventional sources, extraterrestrial sources of the REE that may be useful during future space exploration and exploitation, and the economics of the REE.

McLemore provides an outline of REE potential of mineralizing systems associated with the alkaline igneous rocks along the edge of the Basin and Range province, specifically focusing on the alkaline rocks of the Great Plain Margin, New Mexico, USA [11]. This N-S trending belt of alkaline magmatism is associated with crustal thickening between the Basin and Range and the Rocky Mountains and hosts Th-REE-fluorite $( \pm \mathrm{U}, \mathrm{Nb})$ epithermal mineralization. The gold-rich deposits in this region have moderate to low REE concentrations, although the presence of carbonatites in this region and in associated parts of Mexico suggest that there may be potential for carbonatite-hosted REE mineralization in this area [11].

Smith et al. provide an overview of the REE potential of geothermal brines, a potentially significant resource that could yield sustainable supplies of a wide variety of commodities, not just the REE [12]. The potential co-recovery of geothermal energy also makes these geothermal systems attractive targets for future exploitation. The authors provide an outline of the current state of knowledge on the distribution of the REE within geothermal brines as well as current approaches and the overall feasibility of REE recovery from these geothermal systems [12]. Their overall conclusion is that although these geothermal systems contain interesting concentrations of the REE that technically can be recovered, it is not currently economically viable nor strategically significant to pursue this approach for REE extraction [12].

The research presented by Catlos and Miller focuses on the mineralogy and composition of monazite, a light rare earth element (LREE)-bearing mineral, within the Llallagua tin deposit in Bolivia [13]. The monazite associated with the deposit contains low concentrations of radiogenic elements, a key factor in preventing this mineral being used as a source of the REE elsewhere [5]. Previous research in this area suggests that the monazite in this region formed directly from hydrothermal fluids, meaning the composition of this mineral can provide insights into the fluids that formed the deposit. The monazite at Llallagua contains more $U$ than $T h$, as well as very high concentrations of F, an element that forms complexes with the REE in solution [14] and therefore 
potentially enables these critical elements to be mobilized. The Llallagua monazite contains high concentrations of Eu and has positive Eu anomalies, suggesting the deposit formed in a reduced back-arc environment, potentially as a result of the dissolution of pre-existing fluorapatite. All of these data indicate the usefulness of monazite as a recorder of fluid geochemistry, mineral reactions, and the tectonic settings of associated mineral deposits [13].

The paper by Chen et al. [15] also focuses on monazite, this time within carbonatite deposits, one of the world's most important sources of the REE [3]. The authors state that more than 30 known carbonatite-related REE resources are dominated by monazite, an often secondary mineral within these systems that is associated with apatite. Carbonatite-hosted monazite is geochemically variable but is dominated by the Ce-form of this mineral. These monazites are light REE-enriched, heavy REE-depleted, and are free of Eu and Ce anomalies [15]. These minerals also have Sm-Nd isotopic compositions that are similar to their host rocks, although the Th-U-Pb ages for these minerals generally yield thermal or metasomatic disturbance ages rather than primary ages for the associated carbonatite.

Another globally important set of REE resources are associated with alkaline igneous rocks [3]. Dostal [16] provides an overview of the REE deposits genetically linked with this type of magmatism, where REE mineralization is associated with differentiated rocks that range in composition from nepheline syenites and trachytes to peralkaline granites. The alkaline igneous units associated with these REE enrichments are located in continental within-plate tectonic settings. This REE mineralization is located within layered alkaline complexes, granitic stocks, and late-stages dikes, as well as more rarely within trachytic volcanic and volcaniclastic deposits. Dostal [16] indicates that the majority of alkaline igneous rock-related REE mineralization is present as accessory minerals such as bastnäsite, eudialyte, loparite, gittinsite, xenotime, monazite, zircon, and fergusonite. These minerals are concentrated during the later stages of magmatic evolution, a process that generates the REE enrichments associated with this type of magmatism. In addition, this primary REE mineralization is often remobilized and potentially enriched by late-stage magmatic-hydrothermal fluid activity [16].

McLeod and Krekeler [17] move the focus of this special issue to the Moon and beyond, focusing on potential extraterrestrial sources of the REE. Late-stage lunar magmatism generated residual melts that were enriched in K, the REE, and P (i.e., KREEP). Each of the sets of samples we have from the Moon from the Apollo and Luna missions as well as from the lunar meteorite catalogue contain accessory REE minerals such as apatite, merrillite, monazite, yttrobetafite, and tranquillityite, although lunar REE abundances are low compared to similar terrestrial samples. This indicates that it is currently unlikely that the Moon contains economically relevant abundances of the REE [17]. However, the authors suggest that this may be a result of a lack of information about the Procellarum KREEP Terrane, an area of concentrated KREEP magmatism that may yield locally elevated REE concentrations [17]. This suggests that future lunar exploration and mapping may reveal areas containing elevated concentrations of the REE. McLeod and Krekeler [17] also state that Mars and other extraterrestrial materials contain REE-bearing minerals, albeit at low modal abundances. This indicates that these materials may potentially be sources for the REE as a by-product of the production of other commodities vital to space exploration and utilization [17].

The last paper in the special issue, by Macachek et al. [18], focuses on how the REE fit into a circular economy model whereby resources are kept in use for as long as possible before being recycled into new end-products, ensuring the most is made of the REE originally derived from primary sources. The authors present an overview of the risk and value challenges connected to closing value chain loops and the development of a circular economy within the REE sector [18]. This paper presents a new analytical framework and provides several case studies of loop closure within the REE industry. Macachek et al. [18] also identify how risk-value relationships are constructed and how these can impact the closure of REE value chain loops, or rather what prevents these loops being closed as a result of the different motivations of industry and government agencies. The authors conclude that governments need to mediate against the construction of risk-value relationships by facilitating the generation of information on end-of-life materials. This would enable the REE sector to more effectively 
transition into a circular economy, rather than remaining in the current situation where, for example, only very limited amounts of the REE present in end-products are recycled [9].

These papers not only provide insights into a wide variety of aspects of the REE, but also highlight that research needs to continue into various aspects of the REE to ensure we make the most of the resources of these critical metals.

Acknowledgments: I thank the reviewers who provided constructive reviews of all of the papers within this special issue, enabling the timely production of this issue of Resources. I would also like to thank Damien Giurco and the Resources editorial board for the chance to put this special issue together.

Conflicts of Interest: The author declares no conflict of interest.

\section{References}

1. IUPAC. Nomenclature of Inorganic Chemistry—IUPAC Recommendations; International Union of Pure and Applied Chemistry (IUPAC): Cambridge, UK, 2005.

2. Izatt, R.M.; Izatt, S.R.; Bruening, R.L.; Izatt, N.E.; Moyer, B.A. Challenges to Achievement of Metal Sustainability in Our High-Tech Society. Chem. Soc. Rev. 2014, 43, 2451-2475. [CrossRef] [PubMed]

3. Weng, Z.; Jowitt, S.M.; Mudd, G.M.; Haque, N. A Detailed Assessment of Global Rare Earth Resources: Opportunities and Challenges. Econ. Geol. 2015, 110, 1925-1952. [CrossRef]

4. Nassar, N.T.; Du, X.; Graedel, T.E. Criticality of the rare earth elements. J. Ind. Ecol. 2015, 19, 1044-1054. [CrossRef]

5. Mudd, G.M.; Jowitt, S.M. Rare earth elements from heavy mineral sands: Assessing the potential of a forgotten resource. Appl. Earth Sci. 2016, 125, 107-113. [CrossRef]

6. Sykes, J.P.; Wright, J.P.; Trench, A.; Miller, P. An assessment of the potential for transformational market growth amongst the critical metals. Appl. Earth Sci. 2016, 125, 21-56. [CrossRef]

7. Binnemans, K.; Jones, P.T. Rare Earths and the Balance Problem. J. Sustain. Metall. 2015, 1, 29-38. [CrossRef]

8. Elshkaki, A.; Graedel, T.E. Dysprosium, the Balance Problem, and Wind Power Technology. Appl. Energy 2014, 136, 548-559. [CrossRef]

9. Jowitt, S.M.; Werner, T.T.; Weng, Z.; Mudd, G.M. Recycling of the Rare Earth Elements. Curr. Opin. Green Sustain. Chem. 2018, 13, 1-7. [CrossRef]

10. Binnemans, K.; Jones, P.T.; Blanpain, B.; van Gerven, T.; Yang, Y.; Walton, A.; Buchert, M. Recycling of Rare Earths: A Critical Review. J. Clean. Prod. 2013, 51, 1-22. [CrossRef]

11. McLemore, V.T. Rare earth elements (REE) deposits associated with great plain margin deposits (alkaline-related), southwestern united states and eastern Mexico. Resources 2018, 7, 8. [CrossRef]

12. Smith, Y.R.; Kumar, P.; McLennan, J.D. On the Extraction of Rare Earth Elements from Geothermal Brines. Resources 2017, 6, 39. [CrossRef]

13. Catlos, E.J.; Miller, N.R. Speculations Linking Monazite Compositions to Origin: Llallagua Tin Ore Deposit (Bolivia). Resources 2017, 6, 36. [CrossRef]

14. Migdisov, A.A.; Williams-Jones, A.E.; Wagner, T. An experimental study of the solubility and speciation of the Rare Earth Elements (III) in fluoride-and chloride-bearing aqueous solutions at temperatures up to $300 \mathrm{C}$. Geochim. Cosmochim. Acta 2009, 73, 7087-7109. [CrossRef]

15. Chen, W.; Honghui, H.; Bai, T.; Jiang, S. Geochemistry of Monazite within Carbonatite Related REE Deposits. Resources 2017, 6, 51. [CrossRef]

16. Dostal, J. Rare Earth Element Deposits of Alkaline Igneous Rocks. Resources 2017, 6, 34. [CrossRef]

17. McLeod, C.L.; Krekeler, M.P. Sources of Extraterrestrial Rare Earth Elements: To the Moon and Beyond. Resources 2017, 6, 40. [CrossRef]

18. Machacek, E.; Richter, J.L.; Lane, R. Governance and Risk-Value Constructions in Closing Loops of Rare Earth Elements in Global Value Chains. Resources 2017, 6, 59. [CrossRef] 
Article

\title{
Rare Earth Elements (REE) Deposits Associated with Great Plain Margin Deposits (Alkaline-Related), Southwestern United States and Eastern Mexico
}

\author{
Virginia T. McLemore \\ New Mexico Bureau of Geology and Mineral Resources, New Mexico Institute of Mining and Technology, \\ Socorro, NM 87801, USA; Virginia.Mclemore@nmt.edu; Tel.: +1-575-835-5521
}

Received: 13 November 2017; Accepted: 18 January 2018; Published: 23 January 2018

\begin{abstract}
W.G. Lindgren in 1933 first noted that a belt of alkaline-igneous rocks extends along the eastern edge of the Rocky Mountains and Basin and Range provinces from Alaska and British Columbia southward into New Mexico, Trans-Pecos Texas, and eastern Mexico and that these rocks contain relatively large quantities of important commodities such as, gold, fluorine, zirconium, rare earth elements (REE), tellurium, gallium, and other critical elements. In New Mexico, these deposits were called Great Plain Margin (GPM) deposits, because this north-south belt of alkaline-igneous rocks roughly coincides with crustal thickening along the margin between the Great Plains physiographic province with the Basin and Range (including the Rio Grande rift) and Rocky Mountains physiographic provinces, which extends into Trans-Pecos Texas and eastern Mexico. Since 1996, only minor exploration and development of these deposits in New Mexico, Texas, and eastern Mexico has occurred because of low commodity prices, permitting issues, and environmental concerns. However, as the current demand for gold and critical elements, such as REE and tellurium has increased, new exploration programs have encouraged additional research on the geology of these deposits. The lack of abundant quartz in these systems results in these deposits being less resistant to erosion, being covered, and not as well exposed as other types of quartz-rich deposits, therefore additional undiscovered alkaline-related gold and REE deposits are likely in these areas. Deposits of Th-REE-fluorite $( \pm \mathrm{U}, \mathrm{Nb})$ epithermal veins and breccias are found in the several GPM districts, but typically do not contain significant gold, although trace amounts of gold are found in most GPM districts. Gold-rich deposits in these districts tend to have moderate to low REE and anomalously high tungsten and sporadic amounts of tellurium. Carbonatites are only found in New Mexico and Mexico. The diversity of igneous rocks, including alkaline-igneous rocks, and associated mineral deposits along this boundary suggests that this region is characterized by highly fractionated and differentiated, multiple pulses of mantle-derived magmas evolving to lower crustal magmas related to the subduction of the Farallon plate. The differences in incompatible trace elements, including REE and beryllium, between the different granitic to rhyolite rocks are likely related to either differences in the crustal rocks that were assimilated during magmatic differentiation or by potential minor contamination from crustal sources and/or magma mixing. Deep-seated fracture systems or crustal lineaments apparently channeled the magmas and hydrothermal fluids. Once magmas and metal-rich fluids reached shallow levels, the distribution and style of these intrusions, as well as the resulting associated mineral deposits were controlled by local structures and associated igneous rock compositions.
\end{abstract}

Keywords: gold; REE; alkaline-igneous related deposits; alkaline-igneous rocks; carbonatites 


\section{Introduction}

Lindgren [1] first noted that a belt of alkaline-igneous rocks extends along the eastern edge of the Rocky Mountains and Basin and Range provinces from Alaska and British Columbia southward into New Mexico, Trans-Pecos Texas, and eastern Mexico. These rocks are associated with relatively large quantities of gold, fluorine, zirconium, rare earth elements (REE), tellurium, gallium, and other critical elements [2-5] and over the years, many commodities, especially gold and molybdenum, have been produced from the North American Cordilleran alkaline-igneous belt. Deposits within this belt that have produced significant amounts of gold in the United States and Canada include Cripple Creek, Colorado (731 metric tons of gold production) [5], Black Hills, South Dakota (235 metric tons gold production) and Landsky-Zortman, Montana (71 metric tons gold and 586 metric tons silver production) [6]. Although there has been little REE production from these deposits in the past, exploration is occurring and some could be productive in the future, such as the Bear Lodge Mountains carbonatite deposit in Wyoming, where more than 16.3 million metric tons of $3.05 \%$ total REE are reported [7,8].

Rare earth elements (REE) and other critical elements are increasingly becoming more important in our technological society, and because of the chemical and physical properties of REE, they are used in many diverse defense, energy, industrial, and military applications, like cell phones, computers, magnets, batteries, solar panels, and wind turbines [7-12]. REE include the 15 lanthanide elements (atomic number 57 to 71), yttrium (Y, atomic number 39), and scandium (Sc, atomic number 21; Table 1) and are commonly divided into two chemical groups, the light REE (La through Eu) and the heavy REE (Gd through Lu and Y). REE are lithophile elements (or elements enriched in the crust) that have similar physical and chemical properties, and, therefore, occur together in nature. The name REE is misleading; the content of the REE in the earth's crust ranges from $60 \mathrm{ppm}$ for Ce to $\sim 0.5 \mathrm{ppm}$ for Tb and $\mathrm{Lu}$, which is greater than the crustal abundance of silver (Ag). Four REE (Y, La, Ce and Nd) have larger crustal abundances than lead $(\mathrm{Pb})[8,9]$. However, REE are not always concentrated in easily mined economic deposits and only a few deposits in the world account for current production [8-14]. The U.S. once produced enough REE for U.S. consumption, but since 1999 more than $95 \%$ to $100 \%$ of the REE required by U.S. industries have been imported from China [9,14-16]. However, the projected increase in demand for REE in China, India, United States, and other countries $[8,9,12]$ could result in increased exploration and ultimate production from future deposits in the U.S. and elsewhere [16]. REE deposits have been reported and produced from New Mexico [17-19], but were not considered important exploration targets because the demand in past years has been met by other deposits in the world. Also there are potential permitting and environmental issues that hamper exploration and development in the U.S. However, with the projected increase in demand and potential uncertainty of available production from the Chinese deposits, these areas in New Mexico, Texas, and eastern Mexico should be re-examined for their REE potential.

The North American Cordilleran alkaline-igneous belt is a north-south belt of alkaline-igneous rocks and crustal thickening, roughly coinciding with the Great Plains physiographic margin with the Rocky Mountains and the Basin and Range (including the Rio Grande rift) physiographic provinces (Figure 1) [2,3,20-26]. Chapin et al. [27] referred to this zone as the Rocky Mountain front. Other names include the Eastern Alkalic Belt [28] and the Rocky Mountain Gold Province. In New Mexico, the mineral deposits found in the North American Cordilleran alkaline-igneous belt are associated with Eocene-Oligocene alkaline to calc-alkaline rocks that were called Great Plain Margin (GPM) deposits [23,24,29-32]. This term is retained in this paper and extended to include similar deposits in Trans-Pecos Texas and eastern Mexico.

In New Mexico, the GPM portion of the North American Cordilleran alkaline-igneous belt extends near Raton, southward to the Trans-Pecos alkaline belt (Figure 2). The GPM belt continues into Trans-Pecos Texas and northeastern Mexico. The GPM deposits in New Mexico, Texas, and Mexico are east of the Rio Grande rift, along the border with the Great Plains. 
Many authors have used different classification schemes in describing the mineral deposits found in the North American Cordilleran alkaline-igneous belt. Alternative classifications of these mineral deposits by other workers include Au-Ag-Te veins [33-36], alkalic-gold or alkaline-igneous related gold deposits [2,3,20-22,25,37-39], and porphyry gold deposits [39,40]. REE also are associated with peralkaline intrusion-related igneous systems and some are found in the North American Cordilleran alkaline-igneous belt, but not in New Mexico $([8,39,41]$, this report). The U.S. Geological Survey mineral deposit classification system is used in this study with minor modifications [8,32,34,39].

There are nine types of deposits found in GPM districts in New Mexico, Texas, and Mexico (revised from [19,23,24,32]): (1) polymetallic, epithermal to mesothermal veins (USGS model no. 17, 22b, 22c [33,39]), (2) breccia pipes (USGS model no. 10b, 11d [32,33,39]), (3) porphyry copper-molybdenum-gold (USGS model no. 20c, 21a, 16 [32,39,40]), (4) copper, lead-zinc, and/or gold skarns and/or carbonate-hosted replacement deposits (USGS model no. 18b, 18c, 19a [32,39]), (5) iron skarns and replacement bodies (USGS model no. 18d [32,39]), (6) Th-REE-fluorite ( $\pm \mathrm{U}, \mathrm{Nb}$ ) epithermal veins and breccias (USGS model no. 10b, 11d [32,39]), (7) carbonatites (USGS model no. 10 [8,32,39]), (8) peralkaline intrusion-related REE deposits (USGS model no. $11[8,39,41]$ ) and (9) placer gold (USGS model no. 39a [32,39]) (Table 1). Additional types of deposits are locally found spatially (and perhaps genetically) in the vicinity of GPM deposits: fluorspar vein and breccia deposits (USGS model no. 26b [39]), tungsten-bearing veins (USGS model no. 15a [39]), and volcanogenic beryllium deposits [42]. Most of these deposits are proximal magmatic deposits, whereas iron skarns and replacement bodies are more distal magmatic deposits. Placer gold deposits have been weathered from their original source and have either accumulated in place or been transported, generally by water.

Alkaline- to sub-alkaline-igneous rocks are found in all GPM districts, but gold mineralization is locally associated with older, more silica-saturated (monzonite) or oversaturated (quartz monzonite) rocks $[21,24,43-46]$. Alkaline-igneous rocks are enriched in sodium and potassium $\left(\mathrm{Na}_{2} \mathrm{O}, \mathrm{K}_{2} \mathrm{O}\right)$ relative to similar rocks at given silica $\left(\mathrm{SiO}_{2}\right)$ content. Most GPM deposits are associated with Oligocene intrusive rocks, 38-23 Ma (Figure 2; Table 1), except for the deposits in the Jicarilla Mountains and Orogrande districts, which are associated with Eocene intrusive rocks (39.45-45.6 Ma) (Table 1; [45]). The larger, more productive gold deposits are found in northern and central New Mexico (Figure 2; Table 1). Carbonatites, which are the world's largest economic source of REE today [8], are found only at Laughlin Peak (Chico Hills, Colfax County) [44] and in eastern Mexico [47], but are suspected to occur at depth in the Gallinas Mountains (Table 1).

Since 1996, only minor exploration and development of these REE deposits has occurred because of low commodity prices, permitting issues, and environmental concerns. However, one important change is that now there is an increased demand for critical elements like REE, tellurium, niobium, and other elements that are found in the North American Cordilleran alkaline-igneous belt, including New Mexico's GPM districts $[8,10,48]$. In addition, new geochemical and geochronological data are available in many GPM districts in New Mexico, Texas, and eastern Mexico. Many GPM districts in New Mexico have been mapped or re-mapped as part of the New Mexico Bureau of Geology and Mineral Resources (NMBGMR) geologic mapping program, including the Ortiz porphyry belt, Santa Fe County and the southern Lincoln County porphyry belt (Table 1; http:/ /geoinfo.nmt.edu/publications/maps / geologic/ofgm/home.cfml, accessed 21 January, 2018). This new mapping, along with geochemical and geochronological studies, have revised the volcanic stratigraphy and enhanced our knowledge of the timing of magmatic events, mineralogy and geochemistry, and geologic processes forming GPM deposits in New Mexico. New research at the Round Top Mountain deposit at Sierra Blanca, Texas and newly discovered carbonatites in Mexico also have increased our area of economic interest to the south to include Trans-Pecos Texas and eastern Mexico. Thus, the purposes of this paper are to (1) summarize the geology, geochemistry, geochronology and mineral production of Eocene-Oligocene alkaline-igneous related GPM mineral deposits in New Mexico, Texas, and eastern Mexico, (2) discuss the age and formation of these deposits, and (3) comment on the future economic potential of these mineral deposits in New Mexico, Texas and eastern Mexico. Earlier papers $[23,24]$ described the gold 
potential of GPM deposits in New Mexico; this paper focuses on the REE potential of GPM deposits. This work is part of ongoing studies of mineral deposits in New Mexico and includes updates and revisions of prior work $[4,23,24,30,31,48]$.

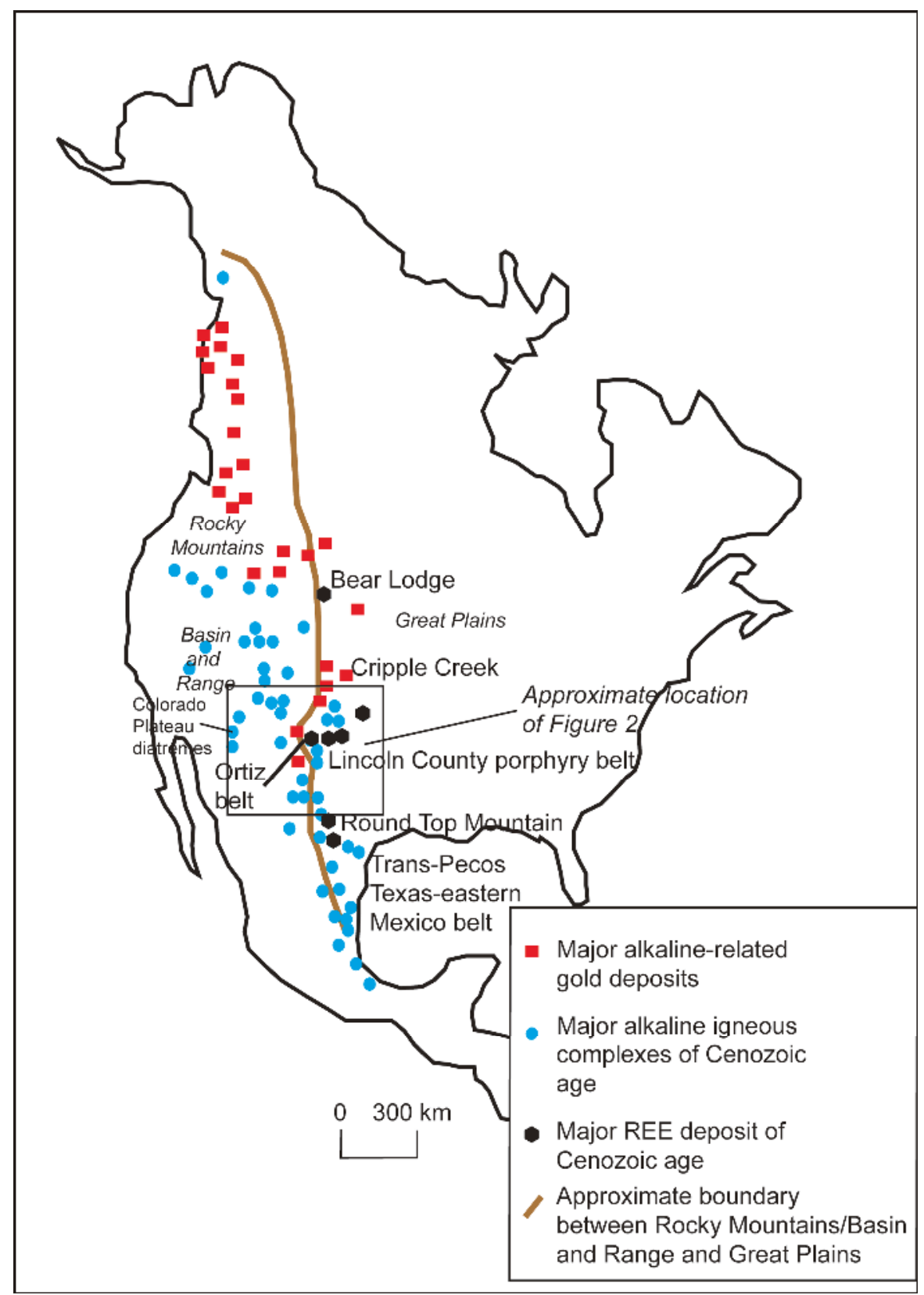

Figure 1. Extent of the North American Cordilleran alkaline-igneous belt [2,3,23,24,49]. 


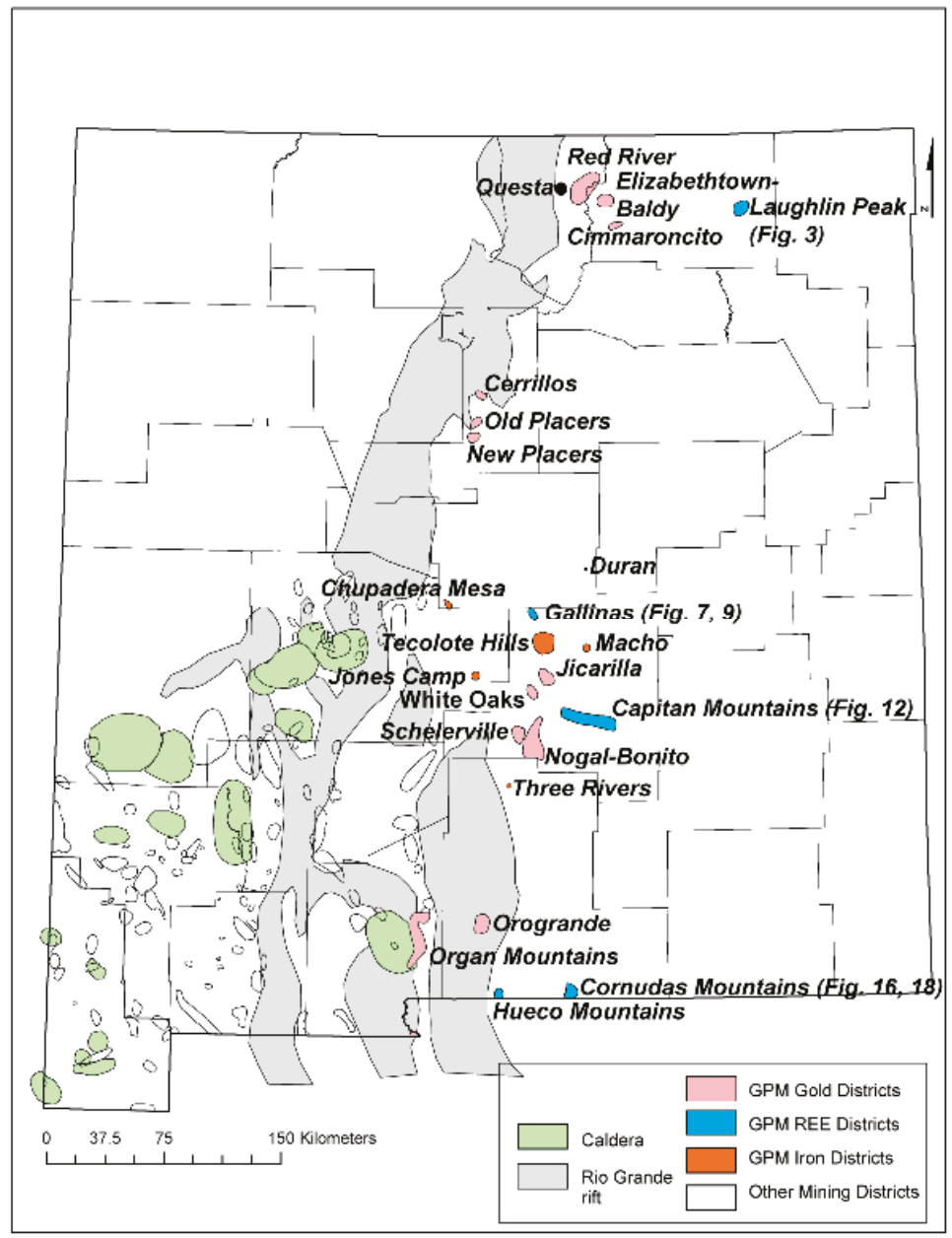

Figure 2. Mining districts related to the North American Cordilleran alkaline-igneous belt (GPM or Great Plains Margin deposits), Rio Grande rift, calderas, and other Eocene-Miocene mining districts in New Mexico [23,24,27,31,32,48-54]. GPM districts are summarized in Table 1. 


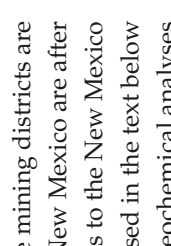

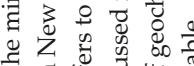

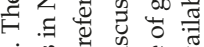

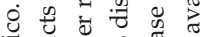

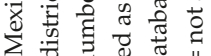

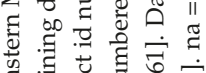

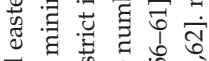
उद्व

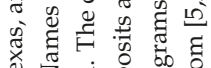

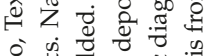
$\therefore$ 음 훙

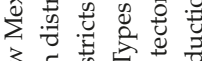

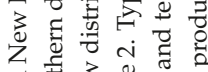

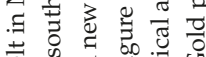
击宫

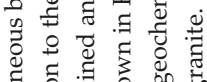
品

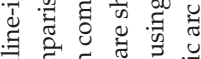

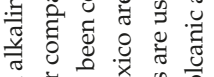

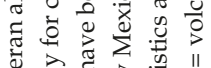

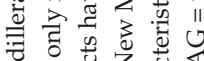

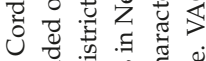

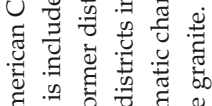

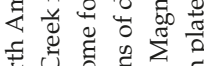
营记

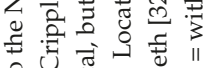

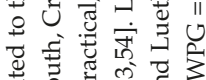

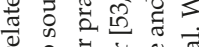

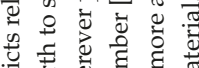

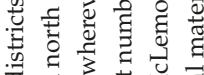

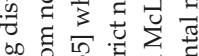

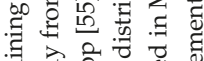

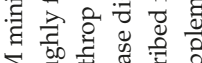

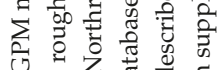

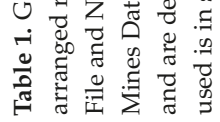

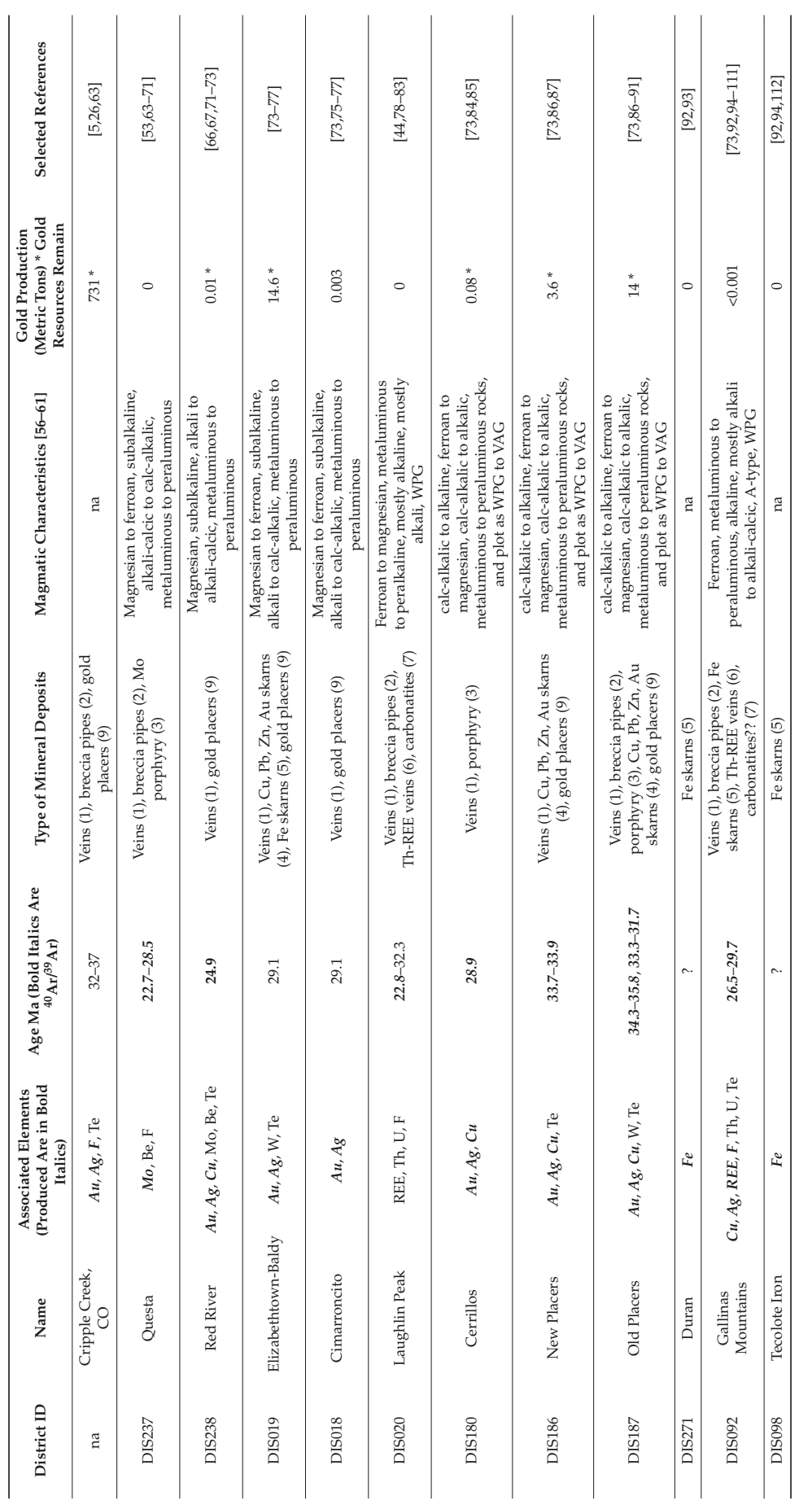




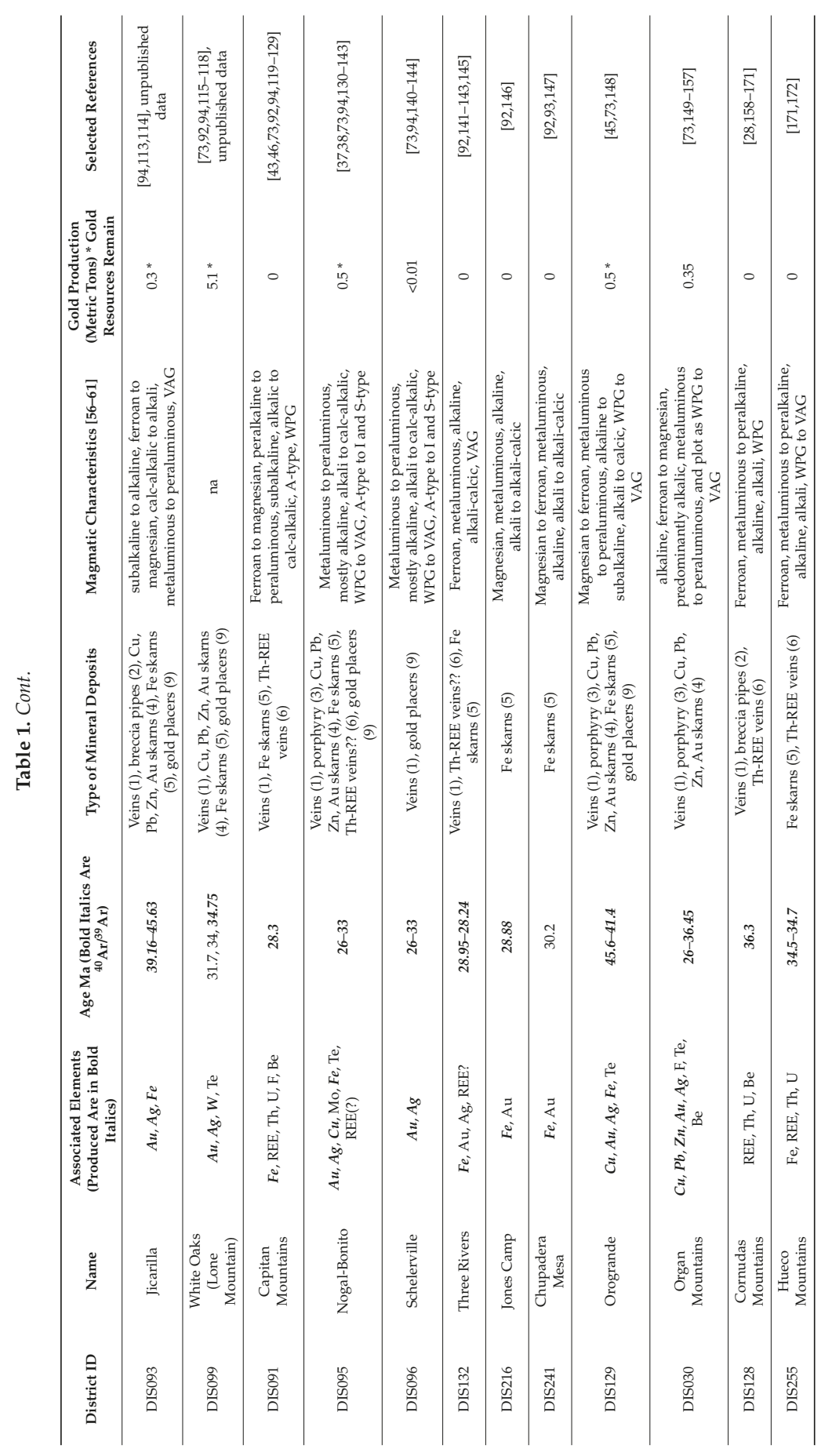


Resources 2018, 7, 8

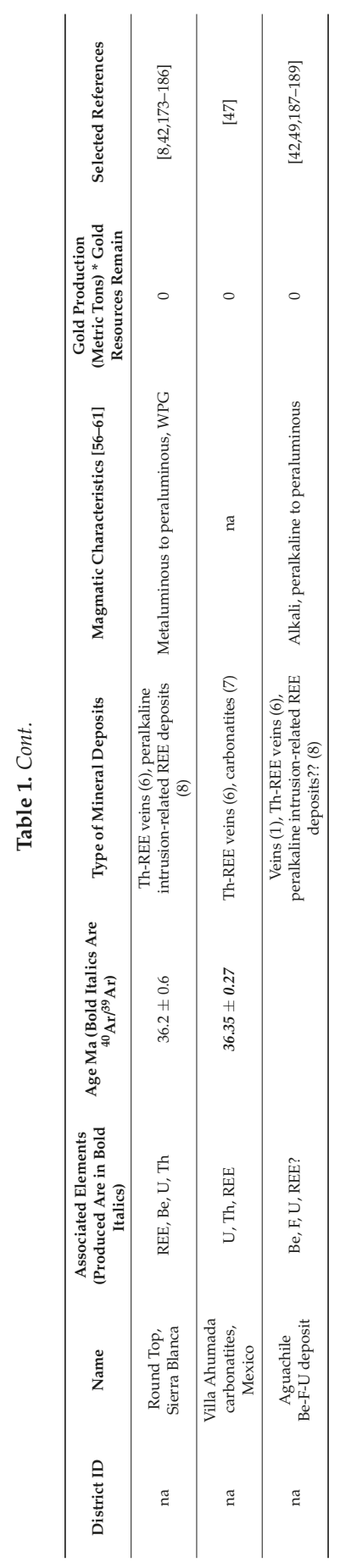




\section{Materials and Methods}

Seven districts containing REE deposits are highlighted in this report and described in Section 3 of this report. Data used in this report have been compiled from a literature review (references cited in Table 1), field examination and mapping by the author, and include the mineralogy, geochemistry, and geochronology of the alkaline-igneous rocks and associated mineral deposits. The geochemical data, analytical precision and accuracy, and analytical methods are described in the various cited reports (Table 1).

Mineral and chemical compositions of igneous rocks in the GPM districts were obtained from numerous reports as cited, as well as unpublished data by the author, and are in the supplemental material. The data were plotted on various standard geochemical and tectonic diagrams [56-61] and compared. These chemical plots are standard methods used to describe and classify igneous rocks and provide a basis for comparisons between areas (Table 1). Only selected plots are shown for space limitations. A variety of nomenclatures for the igneous rocks in these districts were used in previous studies, because the rocks typically are porphyritic in a fine-grained matrix and include shallow intrusions as well as extrusive volcanic rocks. The International classification [190] is used in this report, where the primary classification of igneous rocks is based upon mineralogy and, if too fine-grained to determine mineralogy, by the use of whole-rock geochemical analyses using the TAS (total alkali silica) [190] and R1-R2 [191] diagrams.

Mineral occurrences, deposits, mines, and prospects within GPM districts were compiled from published and unpublished data, summarized in Table 1, plotted on base maps, and entered in the New Mexico Mines Database [53,54,62]. Mineralized areas were examined and sampled during 1980-2017 by the author and during 1982-1993 by the U.S. Bureau of Mines as part of mineral-resource assessments $[82,102,104,119,133,168]$. Arc GIS was used for New Mexico deposits and other regional maps were used for Texas and Mexico.

Any resource or reserve data presented here are historical data and are provided for information purposes only and do not conform to Canadian National Instrument NI 43-101 requirements, unless otherwise stated.

\section{Descriptions of Selected Areas}

\subsection{Laughlin Peak District}

The Laughlin Peak district (DIS091), located within the Laughlin Peak-Chico Hills igneous complex (Figure 3), is in the southern portion of the younger Raton-Clayton volcanic field in northeastern New Mexico, along the Jemez Lineament. The Laughlin Peak-Chico Hills complex was emplaced just before or at the beginning of Rio Grande rift extension (22-37 Ma [44]). The Laughlin Peak-Chico Hills igneous complex consists of a variety of alkaline extrusive (trachyandesite, $32.3 \pm 1.5$, $\mathrm{K} / \mathrm{Ar}$; basalt, trachybasalt, rhyodacite) and intrusive lithologies (Figure 4a), including trachyte $(36.7 \pm 1.3 \mathrm{Ma}, \mathrm{K} / \mathrm{Ar}[78])$, trachyphonolite, trachyandesite, phonotephrite (25.3 $\pm 0.9 \mathrm{Ma}, \mathrm{K} / \mathrm{Ar}$ [79]), Chico Phonolite $\left(22.8 \pm 0.23 ;{ }^{40} \mathrm{Ar} /{ }^{39} \mathrm{Ar}\right.$ [83]), lamprophyre dikes (24.06 $\left.\pm 1.01 \mathrm{Ma}, \mathrm{K} / \mathrm{Ar}[79]\right)$, and carbonatite dikes [44]. Many of the volcanic and intrusive rocks have a porphyritic texture, suggesting emplacement near or at the surface. Associated igneous rocks in the Laughlin Peak district are alkaline (Figure 4b; alkali to calc-alkalic according to Frost and Frost [59]), predominantly ferroan to magnesian, metaluminous to peralkaline and plot as A-type granites and WPG (within-plate granites according to Pearce et al. [57]) (Supplemental Material). The associated igneous rocks exhibit typical light REE-enriched chondrite-normalized REE patterns of alkaline-igneous rocks with no europium anomaly (Figure 4c). Veins are hosted by most volcanic rock types, except the carbonatite dikes. 


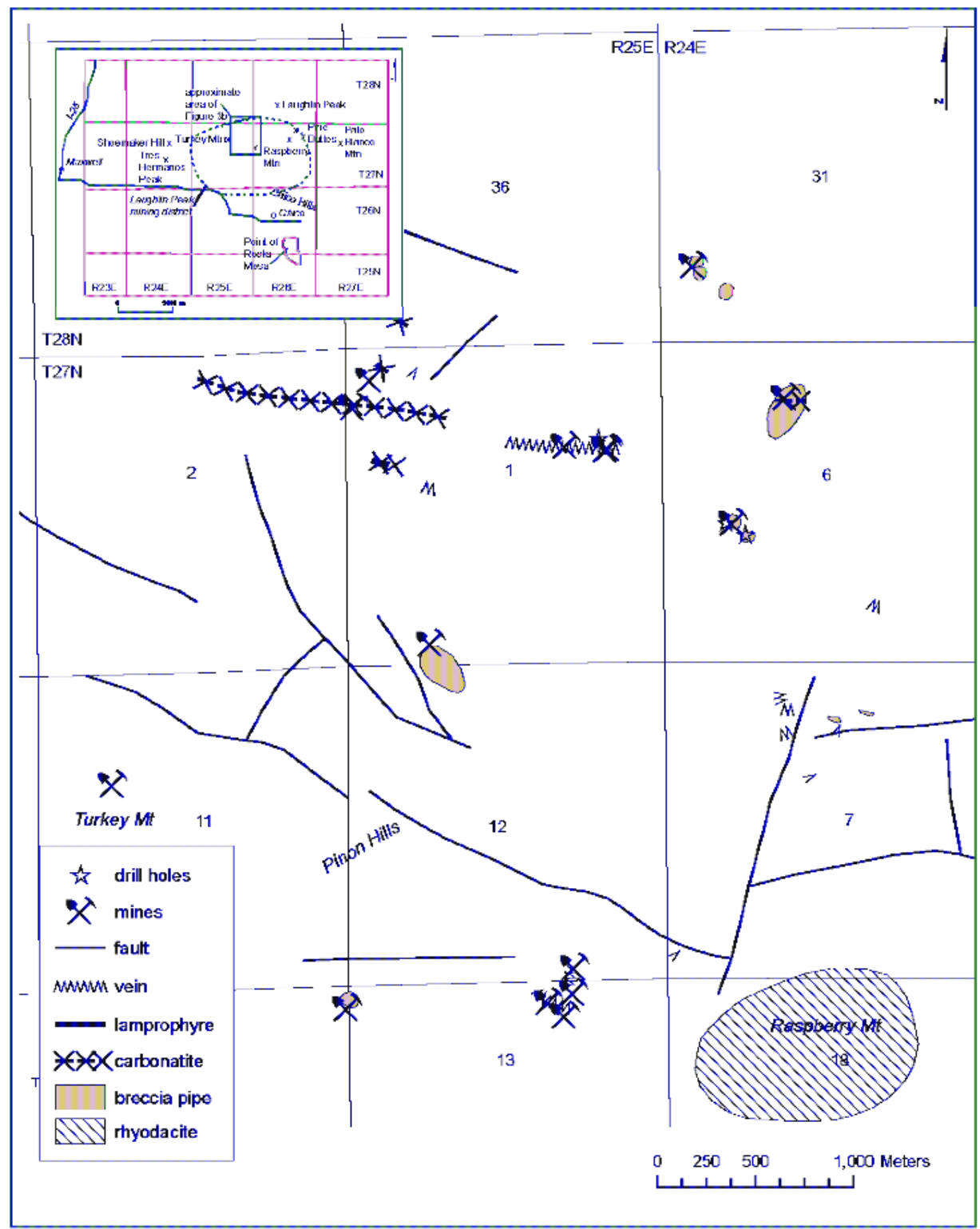

Figure 3. Simplified geologic map of the Laughlin Peak district, Colfax County, New Mexico (simplified from [44,78-80]). Prospects and drill holes are described in McLemore [44]. Gray lines and numbers are township, range and section lines. 


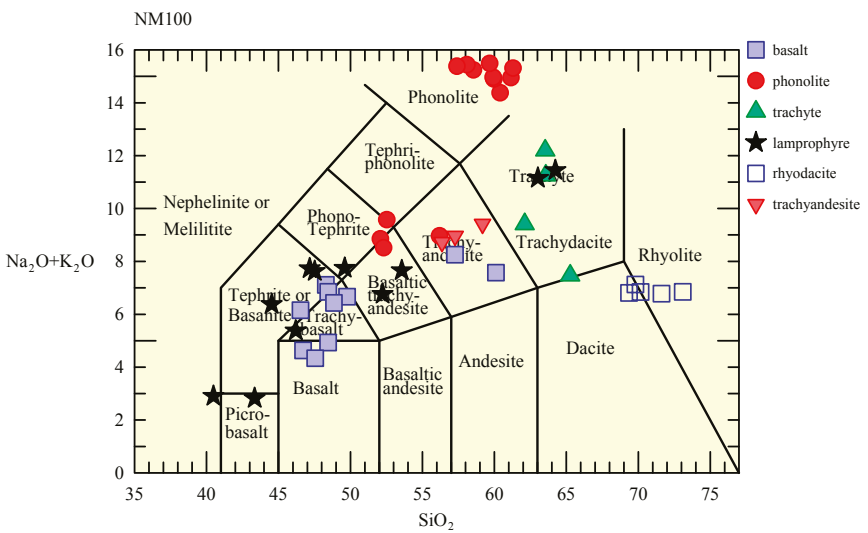

(a)

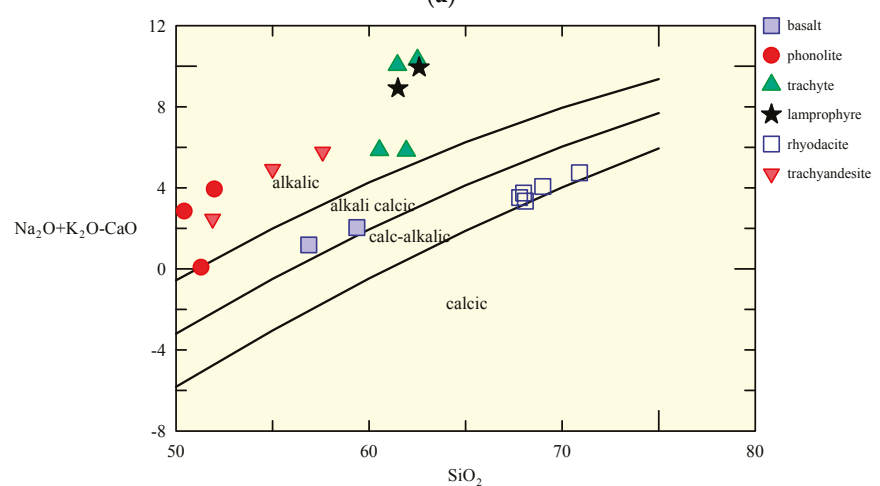

(b)

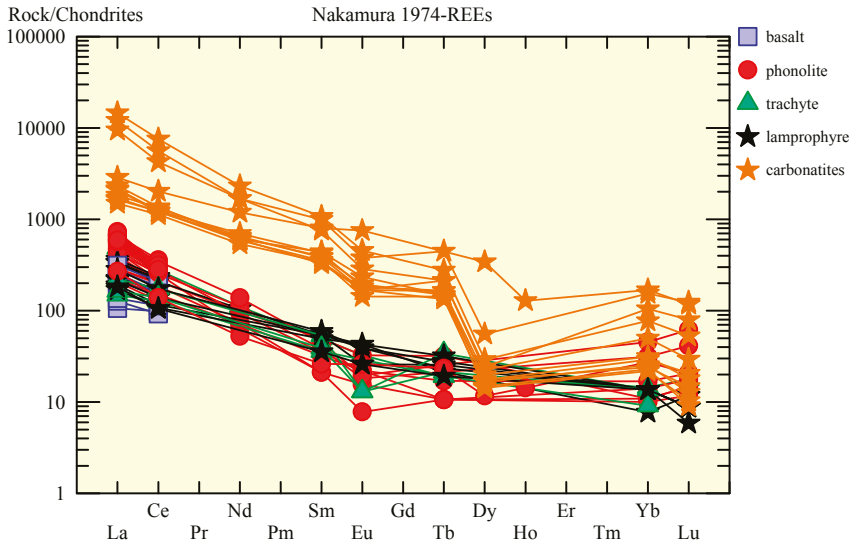

(c)

Figure 4. Chemical plots of igneous rocks from the Laughlin Peak district. Lithological names of samples are from the original data sources ([44,81,82], supplemental material). (a) is the TAS (Total Alkali Silica) diagram [190], (b) is alkaline to calc-alkalic diagram [59], and (c) is a chondrite-normalized REE plot [192]. 
Although there has been no mineral production from the Laughlin Peak district, three types of mineral deposits have been identified: (1) carbonatites, (2) breccia pipe deposits, and (3) Th-REE-fluorite $( \pm \mathrm{U}, \mathrm{Nb})$ epithermal veins and breccias [44]. Carbonatite dikes intrude the Oligocene phonotephrite and are radioactive due to the presence of uranium and thorium minerals $[44,82]$ and have the chemical composition of predominantly calciocarbonatite (Figure 5; also known as calcite carbonatite or sövite; after $[193,194]$ ), with minor ferrocarbonatite and magnesiocarbonatite (also known as dolomite carbonatite or beforsite). The carbonatites are poorly exposed and range in size from $12 \mathrm{~m}$ to $1219 \mathrm{~m}$ long and less than $1 \mathrm{~m}$ wide and consist of predominantly calcite, dolomite, barite, with trace amounts of apatite, goyazite (including REE-rich end member florencite to calcium-rich end member crandallite), bastnaesite, monazite, pyrite, and quartz [44,82]. The Laughlin Peak carbonatites are light-REE enriched and contain $<1.6 \%$ total REE (Figure 6) [44].

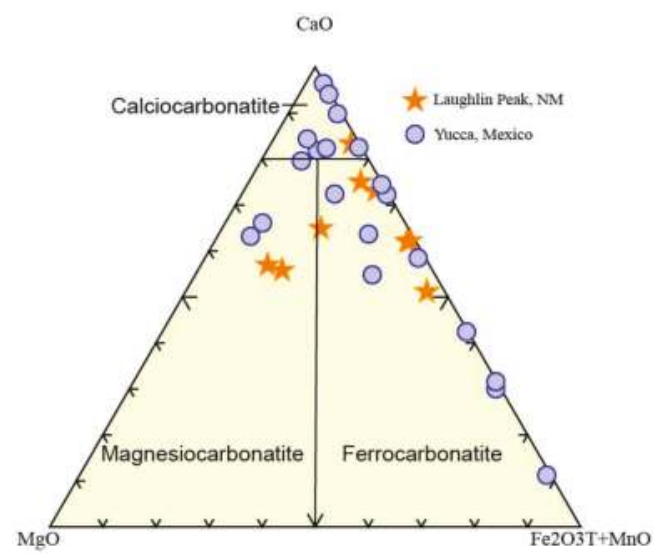

Figure 5. Chemical classification of carbonatites from Laughlin Peak and Mexico. Data from [44,47,82].

The radioactive Th-REE-fluorite $( \pm \mathrm{U}, \mathrm{Nb})$ epithermal veins and breccias cut Cretaceous sedimentary rocks and Tertiary volcanic flows, dikes and sills, strike predominantly west to northwest with steep north or south dips, and are less than $600 \mathrm{~m}$ long and less than $1 \mathrm{~m}$ wide (Figure 3). Minor eat-west faults host veins locally. The veins are in linear zones of brecciated and fractured volcanic and intrusive igneous rocks. Crandallite, xenotime, thorite, and brookite are the predominant REE minerals in a gangue of quartz, calcite, feldspar, and trace amounts of barite, fluorite, rutile, zircon, pyrite, magnetite, and iron and manganese oxides [44,78,82]. The veins are light-REE enriched and contain $<1.2 \%$ total REE (Figure 6 ) and $<165 \mathrm{ppb} \mathrm{Au}([44,82]$, supplemental material). The veins contain as much as 2200 ppm F, 2000 ppm Ba, 532 ppm Nb, 172 ppm U, 75 ppm Ta, and 68 ppm Mo and low or no Te [44].

The radioactive breccia pipes are intrusive and consist of various iron and manganese oxides, angular to subrounded rock fragments (less than $0.6 \mathrm{~m}$ diameter) in a fine-grained siliceous and carbonate matrix of quartz and feldspar. Additional studies are needed to determine the relationship of the carbonate matrix to the carbonatites, if any. The breccia pipes are circular to oval shaped and six of the largest pipes range in size from 46 to $366 \mathrm{~m}$; smaller pipes have been delineated. Quartz, feldspar, and clay are the predominant minerals with trace amounts of gold, niobium rutile (?), pyrite, zircon, xenotime and churchite [44,82]. The total REE is less than $3017 \mathrm{ppm}$ (Figure 6). The breccia pipes also contain as much as 5900 ppm F, 9050 ppm Ba, 535 ppm Nb, 54 ppm U and 82 ppb Au [44,82]. Core from the holes drilled in 1986 consists of predominantly grayish breccia cut by feldspar and iron oxide veinlets. Pyrite and marcasite were disseminated in portions of the core from drill hole 2 . Only low concentrations of gold, silver, and tellurium were found in the core samples [44]. 


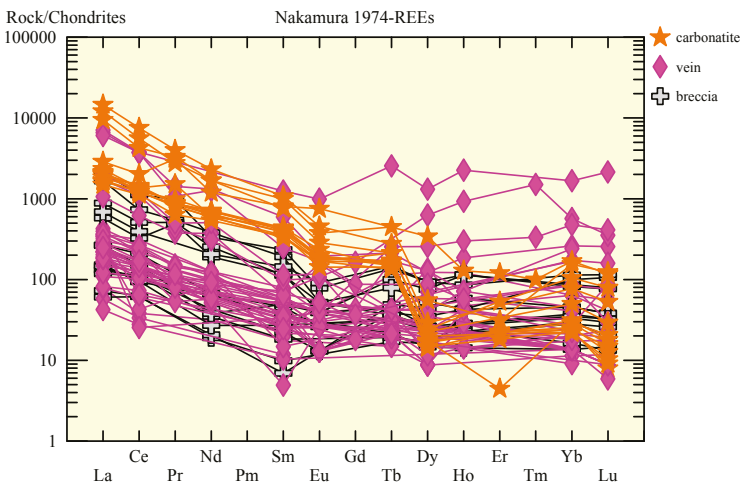

Figure 6. Chondrite-normalized [192] REE plots of veins, breccia pipes, and carbonatites from the Laughlin Peak district. Data are from [44,82].

There is thorium, REE and possibly gold potential in the Laughlin Peak district, but additional drilling is required to more completely understand the mineral-resource potential. The best potential is in the carbonatites and Th-REE-fluorite $( \pm \mathrm{U}, \mathrm{Nb})$ epithermal veins and breccias. However, the Laughlin Peak district is not as faulted (Figure 3) as other GPM districts in New Mexico and this could prevent large, economic deposits from forming. Detailed studies on the mineralogy, geochronology, and paragenesis are still required in the Laughlin Peak district and should be completed before advanced exploration. Such studies will greatly enhance exploration efforts and subsequent processing, should economic deposits be found. Any sampling should include multi-element analyses, especially gold, thorium, REE, niobium, tungsten, and tellurium.

\subsection{Gallinas Mountains District}

The Gallinas Mountains (DIS092) are in northern Lincoln County where a series of alkaline-igneous laccoliths, dikes, and plugs (andesite, porphyritic latite, trachyte/syenite, and rhyolite) have intruded Permian sedimentary rocks (Figure 7) [99,108-110]. The Gallinas Mountains intrusions were emplaced at or just before the beginning of Rio Grande rift extension (27-39 Ma). The oldest intrusion is the porphyritic andesite, which has been dated as $39.74 \pm 0.058 \mathrm{Ma}\left({ }^{40} \mathrm{Ar} /{ }^{39} \mathrm{Ar}\right.$ methods $\left.[110,111]\right)$. The porphyritic latite is $28.178 \pm 0.04 \mathrm{Ma}$. The trachyte intrusion, the largest in the Gallinas Mountains and hosts most of the REE deposits [108], is slightly younger at $27.66 \pm 0.18$ to $29.232 \pm 0.097 \mathrm{Ma}$ $\left({ }^{40} \mathrm{Ar} /{ }^{39} \mathrm{Ar}\right.$ methods $\left.[110,111]\right)$. The syenite lenses within the trachyte are similar in age as the trachyte ( $26.51 \pm 0.15$ to $29.77 \pm 0.16 \mathrm{Ma},{ }^{40} \mathrm{Ar} /{ }^{39} \mathrm{Ar}$ methods $\left.[110,111]\right)$. Brecciation, silicification, chloritization, and fenitization have altered the host rocks $[59,103,104,108]$. Only the trachyte and syenite have been fenitized and has been dated as $\sim 27$ to $\sim 30 \mathrm{Ma}\left({ }^{40} \mathrm{Ar} /{ }^{39} \mathrm{Ar}\right.$ methods [110,111]). Carbonatites are inferred at depth by the presence of fenitization, carbonatization of the breccias, presence of REE (especially bastnaesite) and fluorite, and similarity of the intrusive rocks and mineralization to areas with known carbonatites [108]. Associated igneous rocks (Figure 8a) in the Gallinas Mountains district are alkalic to alkali-calcic (Figure 8b; according to Frost and Frost [59]), predominantly ferroan, metaluminous to peraluminous and plot as A-type granites. The trachyte/syenite and latite samples plot within the within-plate granite (WPA) tectonic field of Pearce et al. ([57]; WPG), whereas the rhyolite samples plots within the volcanic-arc granite field (VAG). Trachyte/syenite and latite are probably related, but the rhyolite could be a separate magmatic event $[108,110]$. The associated igneous rocks exhibit typical light REE-enriched chondrite-normalized REE patterns of alkaline-igneous rocks with no europium anomaly (Figure 8c) (supplemental material).

The fenitization associated with the mineralization in the Gallinas Mountains is found as small, irregular zones that have not been mapped in detailed [104]. The trachyte/syenite, Proterozoic granite 
and granitic gneiss, and magmatic-hydrothermal breccia have been altered locally by two separate periods of fenitization; sodic followed by potassic fenitization. Sodic fenitization is characterized by replacement of feldspars and other minerals by albite. Potassic fenitization is characterized by replacement of feldspars, including older albite, and other minerals by K-feldspar [104].

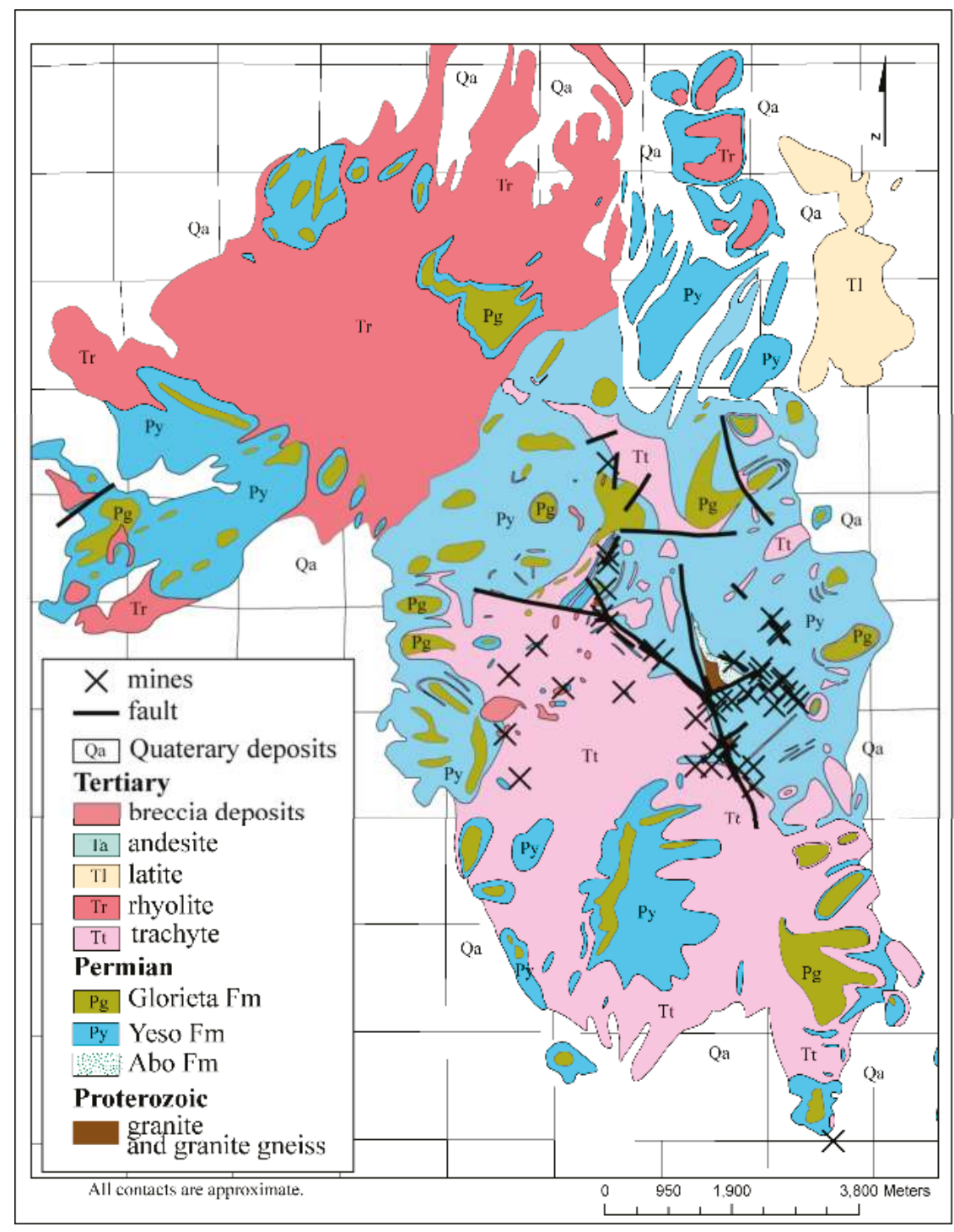

Figure 7. Geologic map of the Gallinas Mountains, Lincoln and Torrance Counties, New Mexico (modified from $[96,98,99,103,104,108]$ ). Fenites are not mapped due to small, irregular zones that would not show at this scale. Gray lines and numbers are township, range and section lines. 


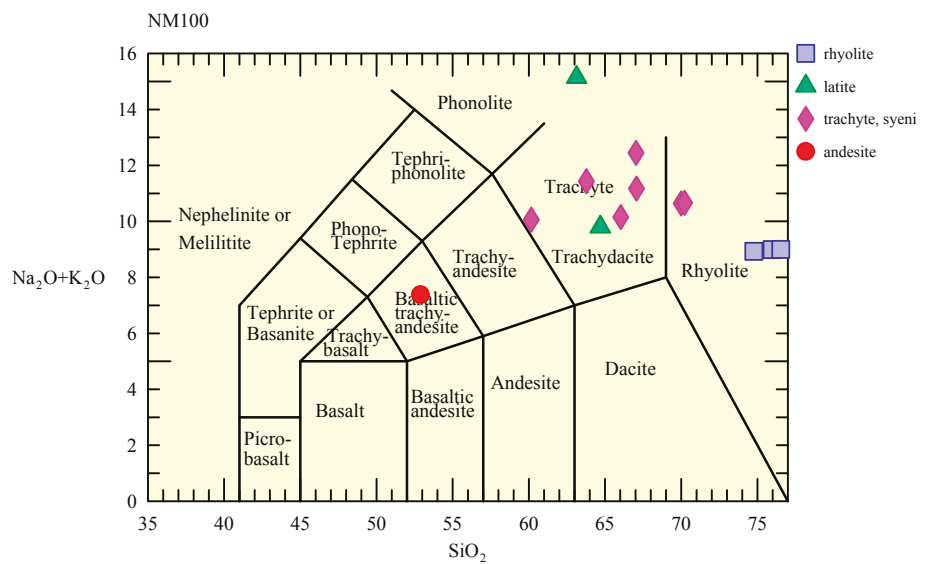

(a)

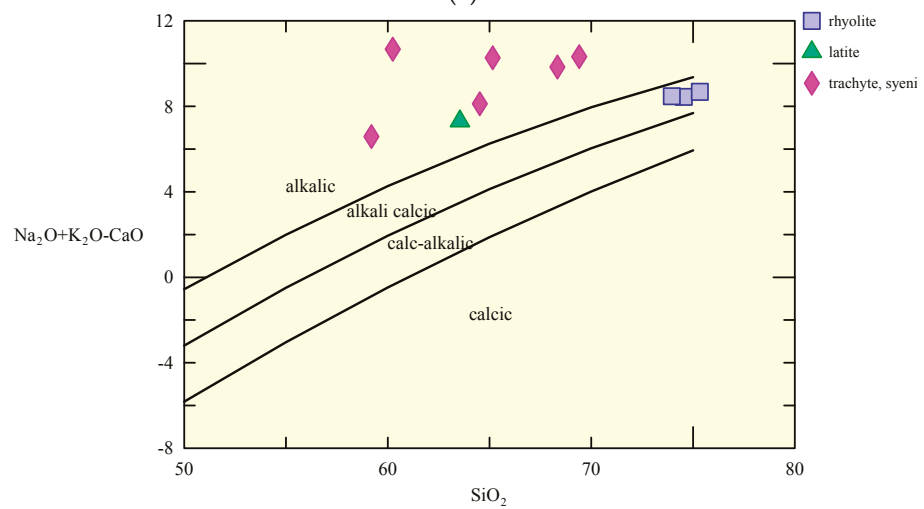

(b)

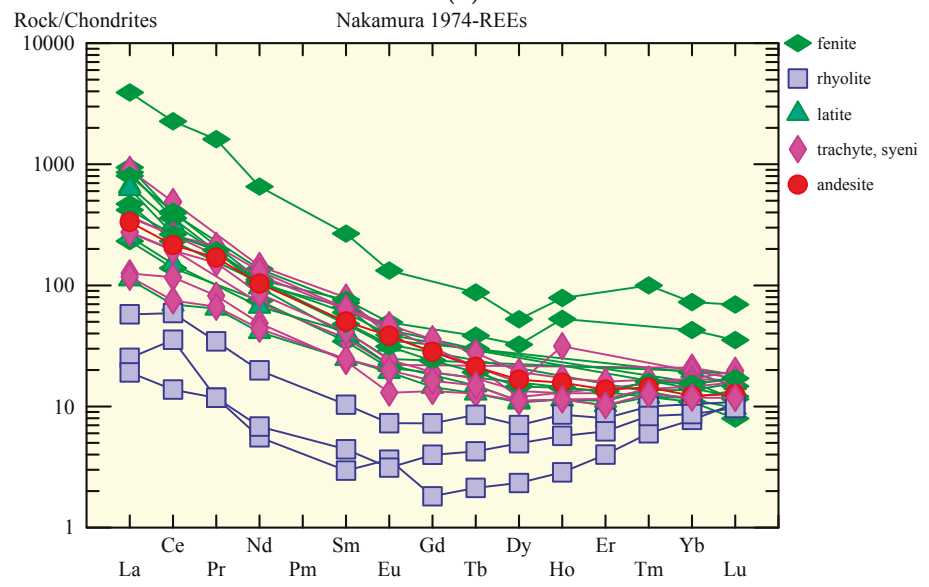

(c)

Figure 8. Chemical plots of igneous rocks from the Gallinas Mountains. Data are from 104, 108, and 110 (supplemental material). (a) is the TAS (Total Alkali Silica) diagram [190], (b) is alkaline to calc-alkalic diagram [59], and (c) is a chondrite-normalized REE plot [192]. 
The Red Cloud, Buckhorn, and Summit mining claims were established in 1881 in the Gallinas Mountains. Iron ore was produced from the American Iron and Red Cliff mines in 1942-1943 [92]. Fluorite was produced from the Red Cloud and Conqueror mines in 1951-1954. Approximately $142,000 \mathrm{lbs}$ of bastnaesite, discovered in the district in 1943 [95,97], was produced from the Red Cloud mine in the 1950s. Exploration was by Phelps Dodge at the Rio Tinto mine in 1980, Molycorp, Inc. in 1980-1981 [104], and Canyon Resources, Hecla Mining Co., American Copper and Nickel, Inc., Romana Resources and Strategic Resources, Inc. in 1989-2015. Production is in Table 2.

Two types of mineral deposits in the Gallinas Mountains are associated with the trachyte/syenite: (1) Th-REE-fluorite $( \pm \mathrm{U}, \mathrm{Nb}$ ) epithermal veins and breccias (REE-F veins, Cu-REE-F veins, and REE-F breccia pipes) and (2) iron skarn deposits [108]. Cu-REE-F ( $\pm \mathrm{Pb}, \mathrm{Zn}, \mathrm{Ag}$ ) veins form center of the district, and are surrounded by REE-F veins (Figure 9). The magmatic-hydrothermal breccia pipe deposits form a belt partially surrounding the veins. Iron skarns formed at the top and edge of the trachyte/syenite body and are likely the earliest stage of mineralization. The iron skarns are probably related to the REE-F veins and breccias because they typically contain bastnaesite and fluorite and are similar in trace element geochemistry. The paragenesis is defined by four stages of brecciation and faulting with three stages of fluorite deposition (Figure 10). REE minerals were deposited during the 1st and 2nd stage of fluorite deposition. Most fenites are more enriched in REE than unaltered igneous rocks $[104,108]$. The mineralogy is diverse and includes fluorite, quartz, barite, pyrite, iron oxides and accessory bastnaesite, calcite, chalcedony, galena, bornite, chalcocite, pyromorphite, anglesite, chrysocolla, malachite, azurite and rare agardite (yttrium-arsenic oxide), mimetite, wulfenite, vanadinite, mottramite, and cerusite [98-101,104]. REE plots of the different types of deposits are shown in Figure 11. Geothermometric fluid-inclusion studies indicate a temperature of formation of $175-185^{\circ} \mathrm{C}[100,106,107]$. Trace-element compositions of fluorites from the Gallinas Mountains are characterized by relatively flat to light REE-enriched chondrite-normalized REE patterns, with no Eu anomaly [107]. The earliest generation of fluorite is similar to the composition of the trachyte/syenite. The fluorite samples plot in the hydrothermal and pegmatitic field [107], which is consistent with a magmatic-hydrothermal origin.

Resources amount to at least 537,000 short tons of 2.95\% total REE (not NI-43-101 compliant; [104,105]. Drilling is required to identify a better resource estimate. The fenites require detailed mapping and evaluation for potential REE.

Table 2. Minerals production from the Gallinas Mountains district, New Mexico.

\begin{tabular}{|c|c|c|c|c|c|}
\hline Mineral Produced & Mine Name & Years of Production & Amount (Short Tons) & Grade \% & Reference \\
\hline Copper & & $1909-1953$ & 192.7 & & [108] \\
\hline Gold & & $1913-1955$ & 6.58 ounces & & [108] \\
\hline Silver & & 1909-1955 & 23,723 ounces & & [108] \\
\hline Zinc & & $1948-1953$ & 8.7 & & [108] \\
\hline \multirow[t]{2}{*}{ Iron ore } & American & $1942-1943$ & 3944 & 55.7 & [92] \\
\hline & Gallinas & 1942 & 6410 & 48.7 & [92] \\
\hline \multirow[t]{3}{*}{ Fluorite } & All American & & 129 & & [195] \\
\hline & Conqueror (Rio Tinto) & & 300 & & [195] \\
\hline & Red Cloud & & 1000 & & [195] \\
\hline \multirow[t]{2}{*}{ Bastnaesite } & Conqueror No. 9 & 1954-1955 & 60 & & [94] \\
\hline & Conqueror No. 10 & 1956 & 11 & & [94] \\
\hline
\end{tabular}




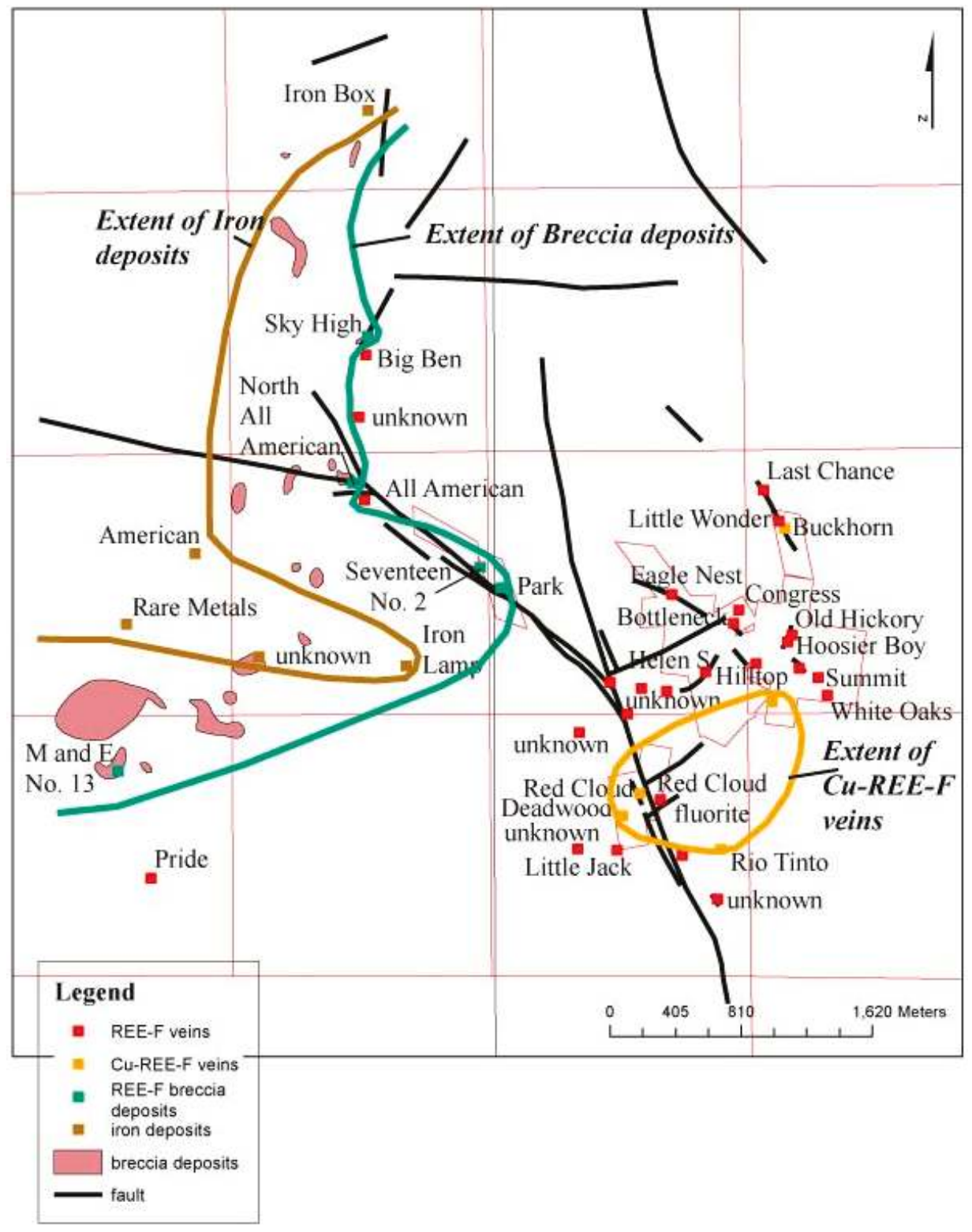

Figure 9. Mineral zoning in the Gallinas Mountains, Lincoln County, New Mexico, based upon predominant mineralogy and chemistry of the known deposits [108]. Fenites are not mapped due to small, irregular zones that would not show at this scale. 


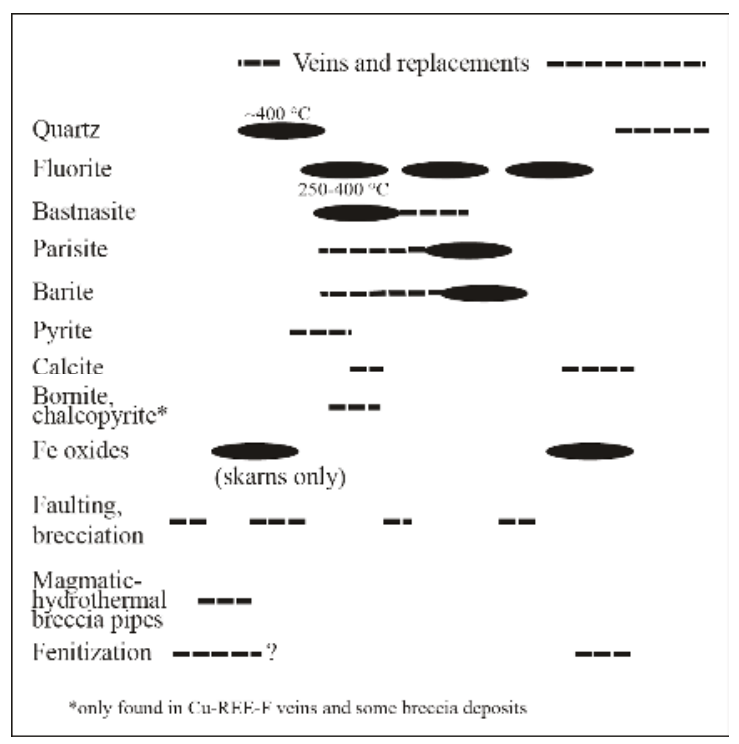

Figure 10. Simplified paragenesis of the REE deposits in the Gallinas Mountains ([108], modified from $[99,104,106])$. Temperature estimates are from [106].

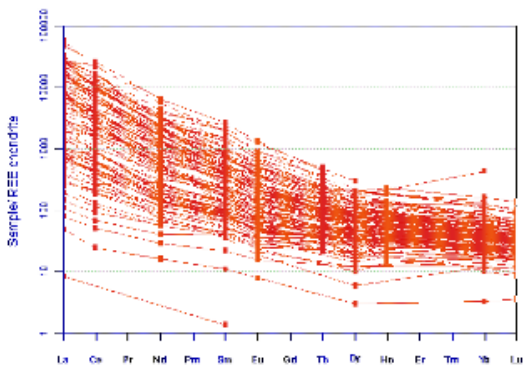

(a)

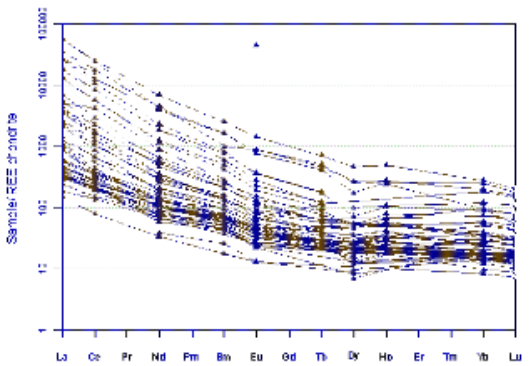

(c)

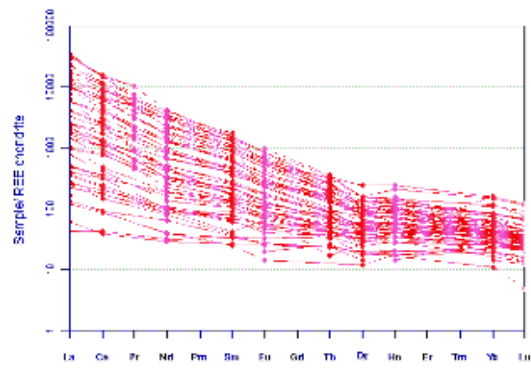

(b)

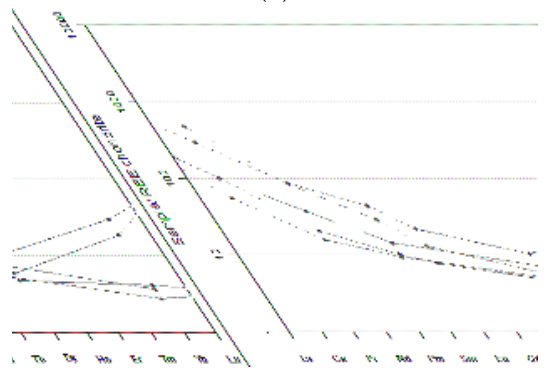

(d)

Figure 11. Chondrite-normalized REE plots [192] (supplemental material) of mineralized samples from the Gallinas Mountains. Data are from 104 and 108. Note the similarity in REE patterns between the different deposit types. (a) REE-F veins (131 samples); (b) Cu-REE-F veins (65 samples); (c) Breccia pipe deposits (58 samples); (d) iron skarns (6 samples). 


\subsection{Capitan Mountains District}

The Capitan Mountains district (DIS091) is associated with the largest exposed Tertiary intrusion in New Mexico, the Capitan pluton, which lies along the east-west trending Capitan lineament (Figure 2) [43,124]. The Capitan Mountains pluton was emplaced during the beginning of Rio Grande rift extension ( $29 \mathrm{Ma})$. The best estimate of the age of the pluton is $28.8 \mathrm{Ma}$, based on ${ }^{40} \mathrm{Ar} /{ }^{39} \mathrm{Ar}$ dating of adularia that is associated with emplacement of the pluton $[43,128]$. The east-west trend of the Capitan pluton reflects the influence the Capitan lineament had on controlling its emplacement. The Capitan pluton hosts Th-REE-fluorite $( \pm \mathrm{U}, \mathrm{Nb})$ epithermal veins and breccias, whereas the Fe skarns and veins and manganese veins and replacement deposits are in limestones adjacent to the Capitan pluton.

The Capitan pluton is a calc-alkaline to subalkaline granite that consists of three textural zones: uppermost granophyric ( 200 m thick), intermediate aplitic ( 200 m), and lower porphyritic $(>1000 \mathrm{~m})$ zones (Figure 12). The textural zones are chemically distinct (Figure 13a-c) suggesting that the zones are related to magmatic and chemical processes, not simple cooling [124]. Chemically the Capitan pluton is ferroan to magnesian, peralkaline to peraluminous, alkalic to calc-alkalic (Figure 13b), and enriched in light REE (Figure 13c). The linear variation in $\mathrm{Na}_{2} \mathrm{O}+\mathrm{K}_{2} \mathrm{O} / \mathrm{SiO}_{2}, \mathrm{SiO}_{2} \mathrm{vs} \mathrm{TiO}_{2}$, and $\mathrm{SiO}_{2}$ vs. $\mathrm{Zr} / \mathrm{TiO}_{2}$, and various major elements confirm that the textural zones are comagmatic [124] (Supplemental Material).

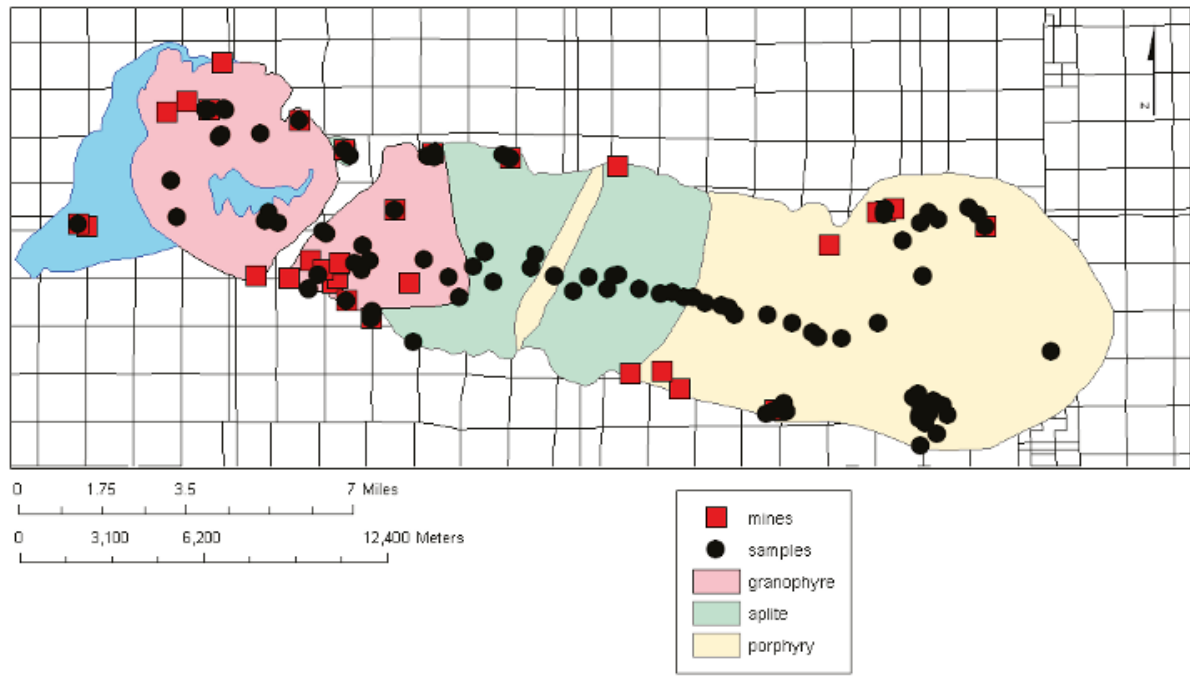

Figure 12. Geologic map of the Capitan Mountains showing the zonation of the Capitan pluton distribution of samples, mines and prospects. Mapping by the author in 1989-1991. The blue zones are Permian sedimentary rocks. The surrounding units (white) are Cretaceous, Permian, and Quaternary sedimentary rocks. Gray lines and numbers are township, range and section lines.

Fine-grained texture, porous zones (i.e., open space fissures and miarolitic cavities) in the granophyric and aplitic zones, and porphyritic texture in the center all suggest a rapid, shallow crystallization of the magma [124,128]. Rare exposures along the northern and southern longitudinal contacts of the pluton with the older Permian sedimentary rocks are slightly dipping away from the pluton. The western and eastern contacts between the pluton and sedimentary rocks dip steeply away from the pluton to vertical. Flat-lying roof pendants of Permian limestone and sills on the western end suggest the pluton is a laccolith or batholith [124]. The sedimentary roof pendants of Permian 
limestone are found west of Capitan Pass (Figure 12). Stoping and assimilation of the sedimentary rocks by the pluton is lacking.

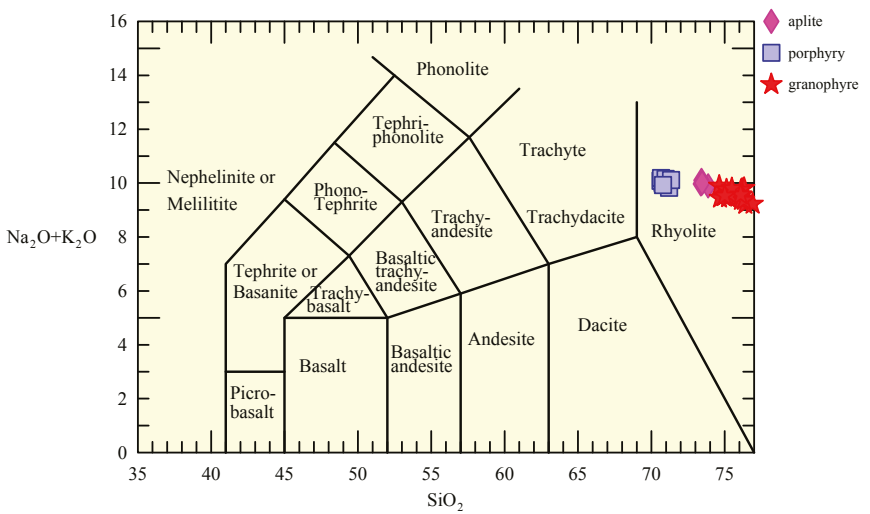

(a)

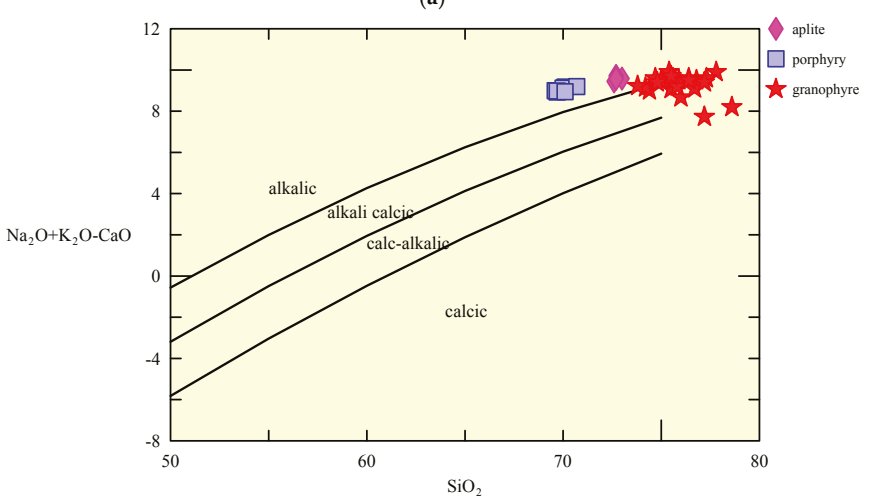

(b)

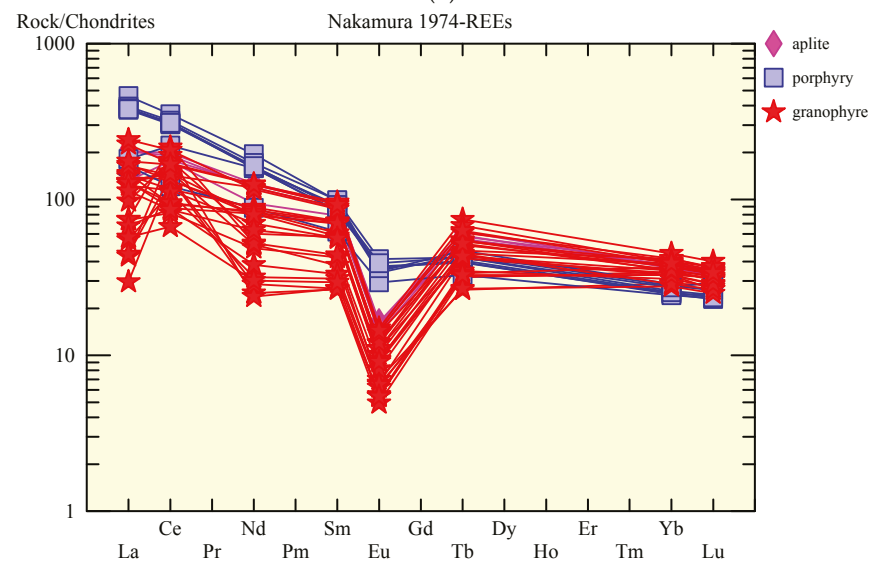

(c)

Figure 13. Chemical plots REE plots of igneous rocks from the Capitan Mountains. Data are from [124,128] (supplemental material). (a) is the TAS (Total Alkali Silica) diagram [190], (b) is alkaline to calc-alkalic diagram [59], and (c) is a chondrite-normalized REE plot [192]. 
The Th-REE-fluorite $( \pm \mathrm{U}, \mathrm{Nb})$ epithermal veins and breccias are exclusively in the granophyric and aplitic zones along the western end of the pluton (Figure 12) and contain trace amounts of gold. Iron skarn and vein deposits are found along the western and northeastern portions of the pluton. Manganese deposits are found along the northeastern portion of the pluton. The Th-REE-fluorite $( \pm \mathrm{U}, \mathrm{Nb})$ epithermal veins and breccias contain quartz, fluorite, adularia, hematite, calcite, fluorite, titanite, allanite, thorite, chlorite, and clay minerals [46]. They probably formed from magmatic fluids as indicated by very highly saline (as much as $80 \%$ eq. $\mathrm{NaCl}$ ) fluid inclusions with homogenization temperatures of $500-600{ }^{\circ} \mathrm{C}[46,120-123,126-128]$. The fluid inclusions contain $\mathrm{Na}, \mathrm{K}, \mathrm{Ca}, \mathrm{Cl}, \mathrm{S}, \mathrm{Fe}, \mathrm{Mn}$, $\mathrm{Zn}$, and light REE as determined from crush-leached samples of quartz and fluorite [123,126]. Similar fluid inclusions are found throughout the granitic rocks of the Capitan pluton [127]. Porous zones are characterized by open spaces, bubble-like features, miarolitic cavities, and fissures along fractures within the granite; are locally associated with Th-REE-fluorite $( \pm \mathrm{U}, \mathrm{Nb})$ epithermal veins and breccias; are found only in the granophyric zone; and are interpreted as pathways that allowed fluids to move through the magma into the outer zones of the pluton, forming the REE-Th-U ( $\pm \mathrm{Au}$ ) veins [128].

Three samples of the Th-REE-fluorite $( \pm \mathrm{U}, \mathrm{Nb})$ epithermal veins and breccias contain higher concentrations of REE than the unaltered/unmineralized Capitan granites and all vein samples are elevated in light REE (Figure 14). One sample from the McCory prospect (\#1784) contained $8133 \mathrm{ppm}$ total REE (Figure 14). A sample from the Fuzzy Nut prospect contained 1110 ppm Th [119]. Staatz [196] reported samples contained less than 0.01 to $1.12 \%$ total REE. Alteration of adjacent rocks to the veins includes minor silicification, hematization, and sericitization. A simplified paragenesis of the REE deposits in the Capitan Mountains is in Figure 15.

The Capitan Mountains REE deposits lie adjacent to a wilderness area and have not been examined for minerals resources, because of potential environmental concerns and permitting issues. However, the Th-REE-fluorite $( \pm \mathrm{U}, \mathrm{Nb})$ epithermal veins and breccias require detailed mapping and sampling to properly assess their economic potential.

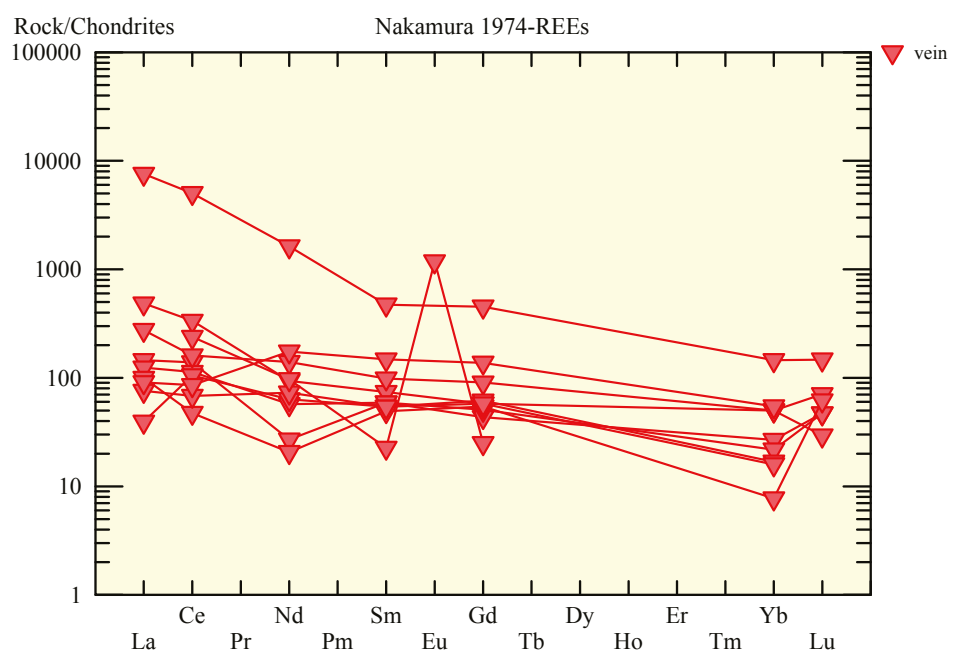

Figure 14. Chondrite-normalized [192] REE plots of Th-REE-fluorite $( \pm \mathrm{U}, \mathrm{Nb})$ epithermal veins and breccias in the Capitan Mountains (supplemental material). Eu was not analyzed in most vein samples, thus the significance of the Eu anomaly is unknown until more analyses are obtained. Note the samples have flat to slightly enriched light REE. 


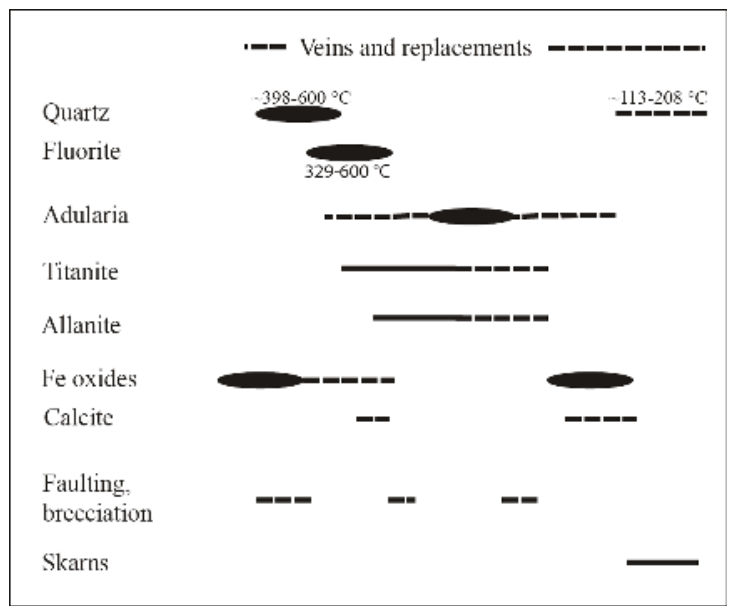

Figure 15. Simplified paragenesis of the REE vein deposits in the Capitan Mountains (modified from [121]). Temperature estimates from [121].

\subsection{Cornudas Mountains District}

The Cornudas Mountains (DIS128) are in southern Otero County, New Mexico and northern Huspeth County, Texas (Figure 2) and form the northern extent of the Trans-Pecos alkaline magmatic province. The Cornudas Mountains pluton was emplaced at or during the beginning of Rio Grande rift extension ( $\sim 33-36 \mathrm{Ma})$. The Cornudas Mountains consist of 10 larger sills, plugs, and laccoliths and smaller dikes and plugs (Table 3, Figure 16) that intrude relatively flat-lying limestones and other sedimentary rocks of the Hueco Limestone and Bone Spring Limestone (Permian). Other dikes, sills, and plugs are buried by sedimentary cover, as indicated by subsurface drilling [197], geophysical surveys, and structural anomalies (i.e., folds, synclines, faults) in the overlying sedimentary rocks. Associated igneous rocks (Figure 17a) in the Cornudas Mountains are alkaline, alkali (Figure 17b; according to Frost and Frost [59]), ferroan, metaluminous to peralkaline and plot as A-type granites and WPG (within-plate granites according to Pearce et al. [57]) (supplemental material). The host igneous rocks exhibit typical light REE-enriched chondrite-normalized REE patterns of alkaline-igneous rocks with no europium anomaly (Figure 17c). The Cornudas Mountains have been examined for potential deposits of Th-REE-fluorite ( $\pm \mathrm{U}, \mathrm{Nb}$ ) epithermal veins and breccias (with associated $\mathrm{REE}, \mathrm{Au}, \mathrm{Ag}$ ) and nepheline syenite as specialty, dimension and crushed stone [167-170]; but there has been no production except for test shipments of nepheline syenite for use as sand-blasting material in 1995.

Table 3. Description of igneous intrusive bodies within the Cornudas Mountains. Bodies shown in Figure 16.

\begin{tabular}{|c|c|c|c|c|}
\hline Name & Form & Predominant Lithology & Age Ma & References \\
\hline Alamo Mountain & $\begin{array}{l}\text { phonolite, foliated } \\
\text { porphyritic nepheline } \\
\text { syenite }\end{array}$ & discordant sheet or sill & $36.8 \pm 0.6(\mathrm{~K} / \mathrm{Ar}$ on biotite $)$ & {$[165,166]$} \\
\hline Flat Top Mountain & $\begin{array}{l}\text { phonolite, augite syenite } \\
\text { dike }\end{array}$ & sill & - & [165] \\
\hline Cornudas Mountain & $\begin{array}{l}\text { quartz-bearing syenite, } \\
\text { syenite, trachyte }\end{array}$ & plug or laccolith & $34.6 \pm 1.5(\mathrm{~K} / \mathrm{Ar}$ on biotite $)$ & {$[165,166]$} \\
\hline Wind Mountain & $\begin{array}{c}\text { nepheline syenite, } \\
\text { phonolite, porphyritic } \\
\text { nepheline syenite }\end{array}$ & Laccolith or plug & $\begin{array}{c}36.32 \pm 0.15\left({ }^{40} \mathrm{Ar} /{ }^{39} \mathrm{Ar}\right. \\
\text { NMBMMR Geochronology } \\
\text { Laboratory). }\end{array}$ & {$[163,165,170,193]$} \\
\hline
\end{tabular}


Table 3. Cont.

\begin{tabular}{|c|c|c|c|c|}
\hline Name & Form & Predominant Lithology & Age Ma & References \\
\hline San Antonio Mountain & nepheline syenite & laccolith & - & [165] \\
\hline $\begin{array}{l}\text { Deer Mountain (Little } \\
\text { Wind Mountain) }\end{array}$ & nepheline syenite & plug or laccolith & $33.0 \pm 1.4(\mathrm{~K} / \mathrm{Ar}$ on biotite $)$ & {$[165,166]$} \\
\hline Chatfield Mountain & phonolite & sill & - & [165] \\
\hline Black Mountain & $\begin{array}{l}\text { porphyritic nepheline } \\
\text { syenite }\end{array}$ & sill & - & [165] \\
\hline Washburn Mountain & $\begin{array}{l}\text { porphyritic nepheline } \\
\text { syenite }\end{array}$ & sill & - & [165] \\
\hline Unnamed hill & $\begin{array}{l}\text { nepheline-bearing augite } \\
\text { syenite }\end{array}$ & plug & $36.8 \pm 0.6(\mathrm{~K} / \mathrm{Ar}$ on biotite $)$ & {$[165,166]$} \\
\hline
\end{tabular}

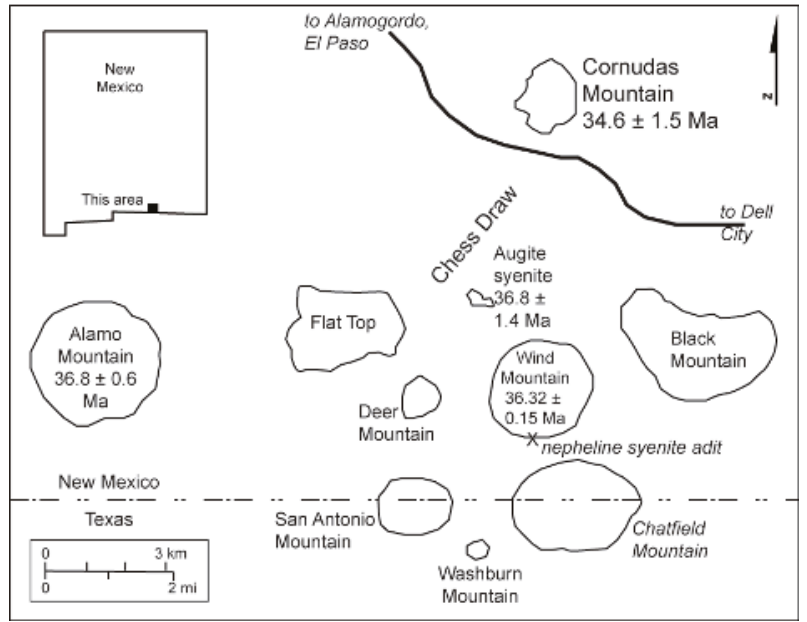

Figure 16. Locations of various igneous plutons in the Cornudas Mountains, New Mexico. See Table 3 for a summary of their lithology and age.

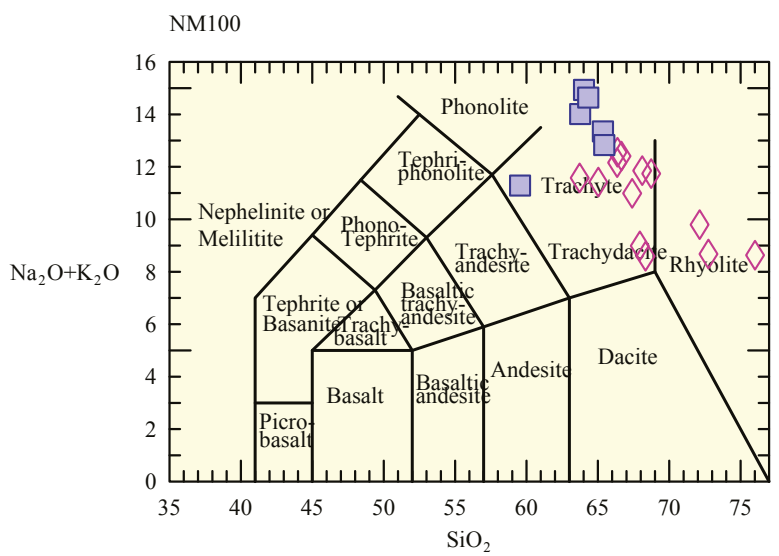

(a)

Figure 17. Cont. 


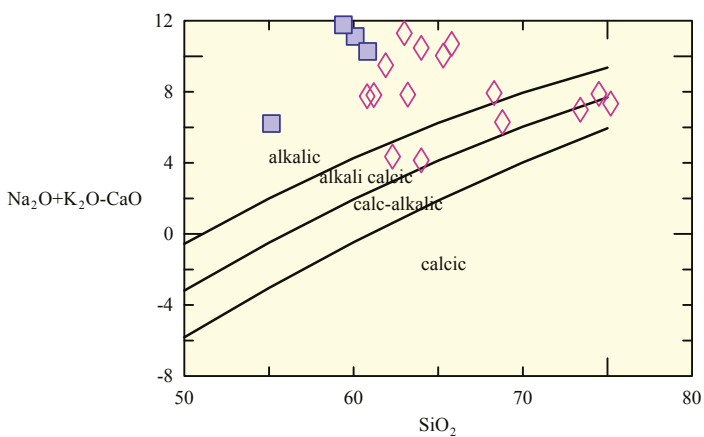

(b)

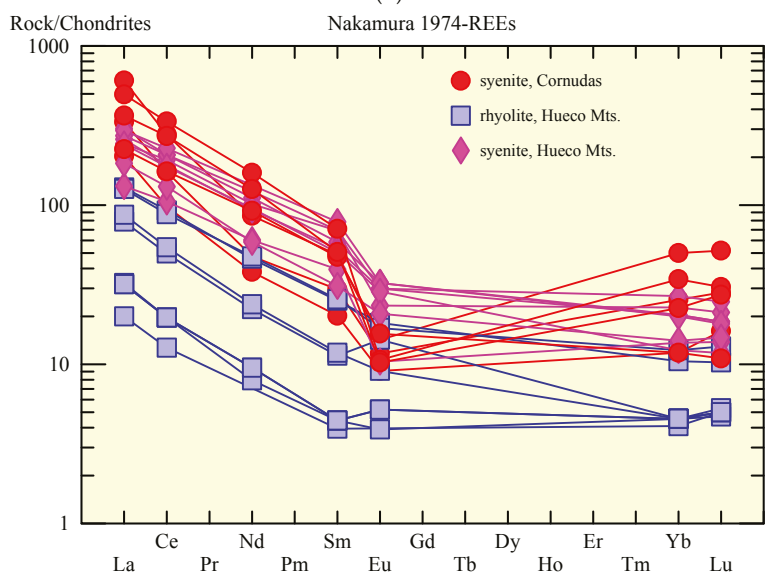

(c)

Figure 17. Chemical plots of igneous rocks from the Cornudas and Hueco Mountains. Data are from $([28,169,171,172]$, supplemental material). (a) is the TAS (Total Alkali Silica) diagram [190], (b) is alkaline to calc-alkalic diagram [59], and (c) is a chondrite-normalized REE plot [192].

In the 1950s, prospectors located several areas of anomalously high radioactivity in the Cornudas Mountains and attributed it to the presence of uranium. Shallow prospect pits were dug on many of the claims in the area; but, assay results were low and the claims were later dropped with no production. In 1956, the U.S. Atomic Energy Commission examined the area to evaluate the potential for uranium [162]. No further work was recommended. Beryllium was first reported from the Cornudas Mountains during the 1940s [163]. A few companies have examined the Cornudas Mountains unsuccessfully for high concentrations of REE, niobium, zirconium, and titanium. In 1984, Leonard Minerals Co. in conjunction with U.S. Borax Corp. conducted an exploration program for REE, niobium, and zirconium. Mapping, sampling, and drilling in the Chess Draw area failed to discover any significant mineralized zones (NMBGMR files). In 1992-1993, Addwest Minerals, Inc. examined the Wind Mountain nepheline syenite laccolith for use in glass and ceramics and delineated 10 million short tons of resources [168,169]. Geovic Mining Corp. acquired property in the Cornudas Mountains about 2010, and conducted a sampling and drilling program. Results are unknown.

The Wind Mountain laccolith consists of three major mineralogical and textural zones (Figure 18) [168,169]. The laccolith is typically gray to cream colored and weathers to darker colors. Accessory minerals form dark-colored aggregates dispersed throughout the rock. The margin of the laccolith is foliated. The foliation dips steeply away from the center of the intrusive body. Chemical 
variations among the individual map units within the laccolith cannot be readily discerned by utilizing major element analyses [168,169]. These chemical analyses of the Wind Mountain laccolith suggests that the zonation appears to be controlled by crystal fractionation, volatile separation, and cooling history, not different pulses of magma [168,169]. Feldspar crystallization under initially subsolvus conditions can account for most of the variations in the zones. The feldspar-rich solid forms at or migrates towards the top of the magma chamber and forms a capping syenite. Differential cooling of the magma resulted in the textural variations at Wind Mountain.

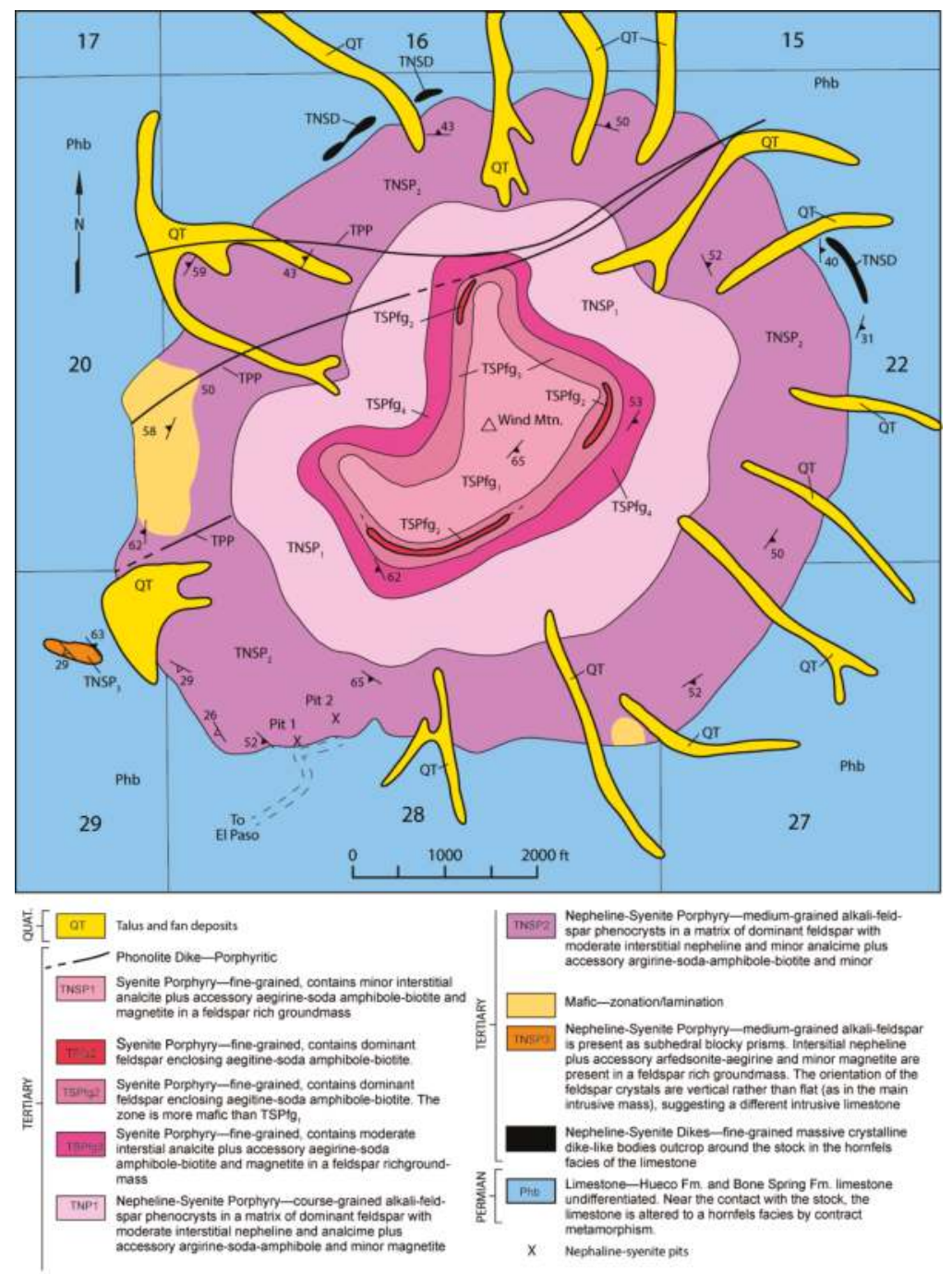

Figure 18. Geologic map of Wind Mountain showing geological zonation [169]. See Figure 16 for location of Wind Mountain in the Cornudas Mountains. Mapping by P. Graeah in 1992.

In the Chess Draw area (northwest of Wind Mountain), a few radioactive dikes and Th-REE-fluorite $( \pm \mathrm{U}, \mathrm{Nb})$ epithermal veins and breccias have been examined for mineral-resource potential. Uranium 
and thorium are found disseminated within the dikes, veins, and breccias but are not economic. Assays ranged from 0 to $0.8 \% \mathrm{U}_{3} \mathrm{O}_{8}$ [162] and 13-351 ppm Th [168]. Past exploration for Be in the Cornudas Mountains was inconclusive. A few samples assayed as much as $0.2 \% \mathrm{BeO}$ [163]. Beryllium is found in feldspar, nepheline, aegirine, and eudialite within dikes, sills, and laccoliths in the Cornudas Mountains; no Be minerals have been identified. U.S. Borax sampled and drilled in the Chess Draw area, but their assays were low (Figure 19; up to $0.06 \%$ total REE oxides, 10-1400 ppm Nb, 10-3000 ppm $\mathrm{Zr}, 230-13,000 \mathrm{ppm}$ F). An analysis of a dike [17,18] contained 1235 ppm Ce, 700 ppm La, 270 ppm $\mathrm{Nd}$, and $242 \mathrm{ppm} \mathrm{Y} \mathrm{(sample} \mathrm{\# 7368).} \mathrm{Other} \mathrm{analyses} \mathrm{[168]} \mathrm{also} \mathrm{are} \mathrm{low} \mathrm{and} \mathrm{subeconomic:} \mathrm{as} \mathrm{much}$ as 3790 ppm total REE, 2332 ppm Nb, 92 ppm Be, and 3137 ppm F. Reconnaissance mapping of the area reveals no additional deposits and the limited geophysical surveys are inconclusive [170], but detailed mapping of the areas surrounding Wind Mountain is required to properly assess the economic potential. Still, additional mineral-resource potential in the Cornudas Mountains is probably limited $[168,170]$, but detailed geochemical, geophysical, and other exploration techniques are required to properly evaluate this area, especially in dikes and along intrusive contacts with the limestones.

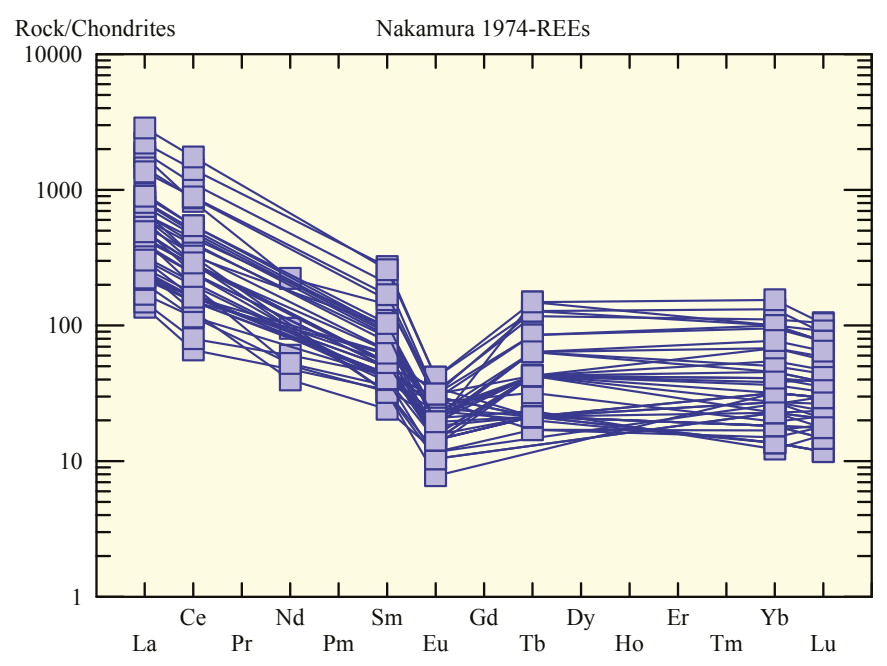

Figure 19. Chondrite-normalized [192] REE plots of mineralized veins and breccias from the Cornudas Mountains. Data are from ([168], supplemental material).

\subsection{Sierra Blanca (Round Top Mountain)}

Sierra Blanca, Texas is south of the Cornudas and Hueco Mountains, New Mexico, and is part of the Trans-Pecos alkaline magmatic province (Figures 1 and 20). Sierra Blanca consists of five rhyolite domes or laccoliths (Round Top, Little Round Top, Little Blanca, Sierra Blanca and Triple Hill) that host peralkaline intrusion-related REE deposits [41]. The rhyolites are peralkaline to peraluminous [198], 36.2 Ma [166], and enriched in Li, Be, F, Zn, Rb, Y, Zr, Nb, Sn, REE, and Th [175,176]. Fluorspar replacement bodies, enriched in $\mathrm{Be}, \mathrm{Zr}, \mathrm{REE}$, and other elements are found at the contacts of the laccoliths and Cretaceous limestones [173-176,183,184]. 


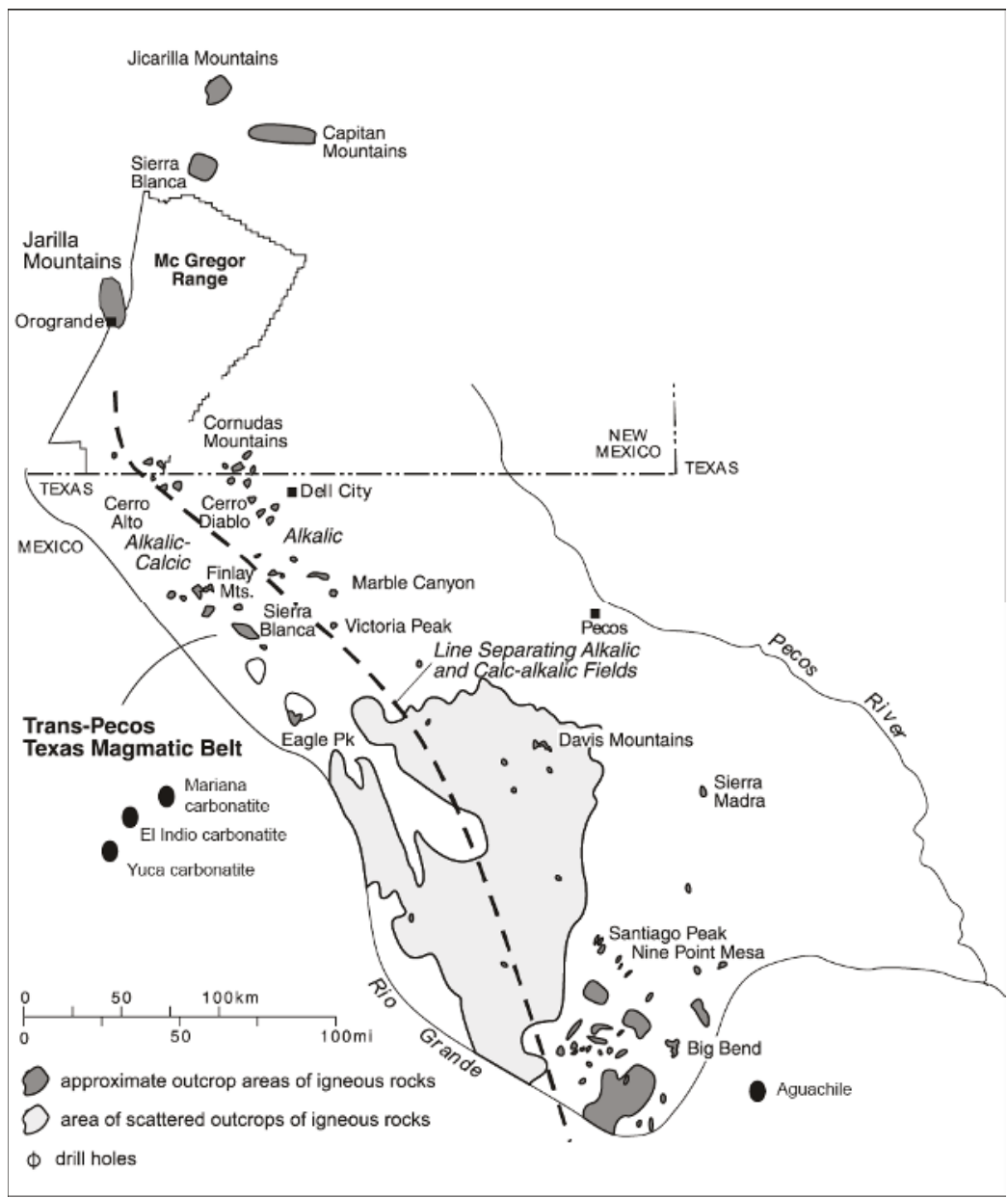

Figure 20. Trans-Pecos magmatic province, New Mexico, Texas, and eastern Mexico (modified from $[165,179])$.

In 1984-1985, Cabot Corporation drilled and found Be-F veins and replacements of limestone adjacent to the rhyolite dome at Round Top Mountain. A 38-m decline was constructed by Cyprus Sierra Blanca, Inc., successor to Cabot Corporation, and the West End structure was reported to contain 300,000 short tons of $1.9 \% \mathrm{BeO}$ at a cutoff grade of $0.5 \%$. The entire project area was reported to contain 25 million pounds of $\mathrm{BeO}$ [180]. In 1993, Cyprus merged with Amax becoming Cyprus-Amax, which subsequently merged with Phelps Dodge in 1999. Grades exceeding 1\% U are found in the deposits. In 2007, Standard Silver Corp. acquired the Round Top Mountain deposits and in 2011, changed their name to Texas Rare Earth Resources Corp. The deposit contains an estimated 231.0 Mt of rare-earth mineral resources at the Measured level, with an average grade of $0.06 \mathrm{wt} \%$ total rare-earth oxide (TREO), 298.0 Mt of resources at the Indicated level, with an average grade of $0.06 \%$ TREO, and an estimated $377.0 \mathrm{Mt}$ of resources at the Inferred level, with an average grade of $0.06 \%$ TREO.

The Round Top Mountain rhyolite intruded Cretaceous limestone and was subsequently hydrothermally altered (fluoritization, kaolinization). The rhyolite is gray, fine grained with visible local flow banding and contains a variety of minerals [198]. Nearby Sierra Blanca rhyolite 
is $36.2 \pm 0.6 \mathrm{Ma}(\mathrm{K} / \mathrm{Ar}$, biotite, 166) and Round Top Mountain rhyolite is likely similar in age. The rhyolite domes at Sierra Blanca are enriched in $\mathrm{Li}, \mathrm{Be}, \mathrm{F}, \mathrm{Zn}, \mathrm{Rb}, \mathrm{Y}, \mathrm{Zr}, \mathrm{Nb}, \mathrm{Sn}, \mathrm{REE}$, and Th and depleted in $\mathrm{Mg}, \mathrm{Ca}$, and Ti relative to typical calc-alkaline rhyolites [175]. Chemically, the rhyolite is alkaline, peralkaline to peraluminous and similar to topaz-bearing rhyolites. The Sierra Blanca pluton was emplaced just before the beginning of Rio Grande rift extension ( 36 Ma). Chondrite-normalized enriched REE patterns exhibit depleted light REE patterns with a negative Eu anomaly (Figure 21). REE minerals include Y-bearing fluorite, bastnaesite, xenotime, and fluocerite $[184,186]$. Beryllium occurs mostly in contact metasomatic veins and replacements in limestones as behoite $\left(\mathrm{Be}(\mathrm{OH})_{2}\right)$, with lesser amounts of berborite $\left(\mathrm{Be}_{2}\left(\mathrm{BO}_{3}\right)(\mathrm{OH}, \mathrm{F}) \cdot \mathrm{H}_{2} \mathrm{O}\right)$, bertrandite, chrysoberyl, phenakite, fluorite and garnet $[175,176,179]$. The mineralization appears to be formed by high-temperature, volatile-rich vapor release during the late stages of fractional crystallization [198].

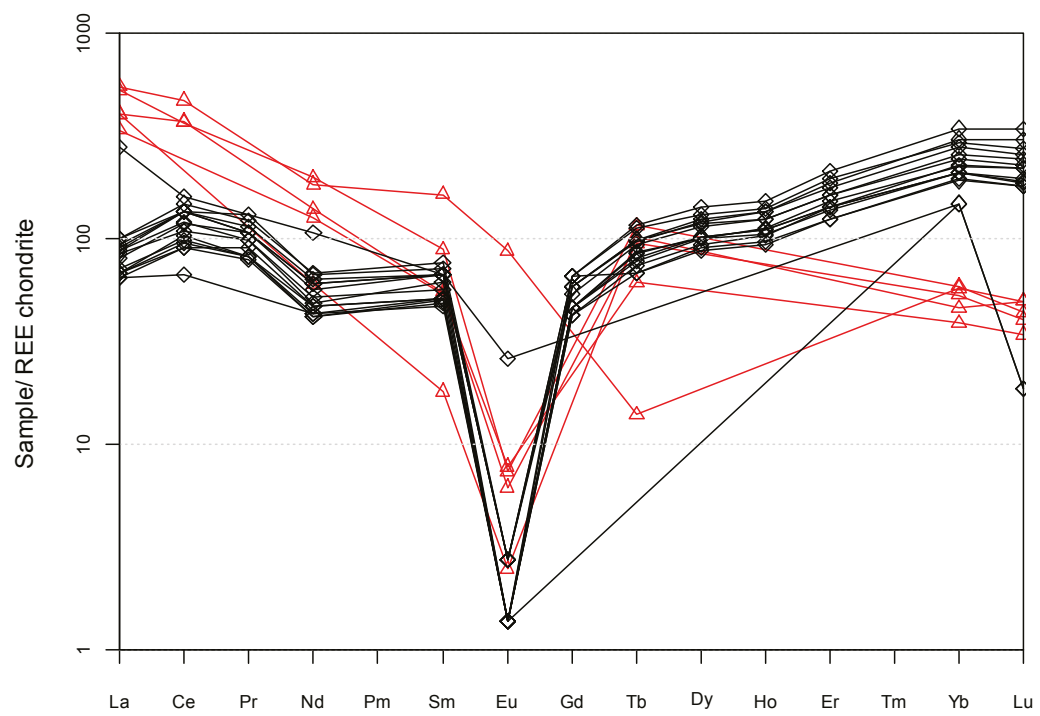

Figure 21. Chondrite-normalized [192] REE plots of the Sierra Blanca (black diamonds) and Aguachile (red triangles) rhyolites ([179,189], supplemental material).

\subsection{Aguachile, Coahuila, Mexico}

The Aguachile Be-F-U deposit in Coahuila, east of Big Bend National Park, Texas, is one of the eastern-most of the fluorite deposits in Mexico [42,49,187-189] and is part of the Trans-Pecos alkaline magmatic province (Figures 1 and 20). The Aguachile Mountain pluton was emplaced at or during the beginning of Rio Grande rift extension ( 33-36 Ma). Aguachile Mountain is a collapse caldera and is surrounded by rhyolite domes with a plug of microsyenite that intruded Cretaceous limestones. Rhyolite and basanite ring dikes surround the dome and plug. Be-U-F veins, breccias, and replacements are found in limestone adjacent to the rhyolite dikes and contain fluorite, calcite, quartz, hematite, limonite, and minor amounts of aragonite, powellite, adularia, kaolinite, gypsum, sericite, and bertrandite $[186,188]$. The major ore body at Aguachile contains $0.1-0.3 \% \mathrm{BeO}$ and beryllium is found only in the immediate Aguachile area, however the presence of peralkaline intrusion-related REE deposits is possible. Three periods of fluoritization are recognized [188]. Chemically the rhyolite is alkaline, peralkaline to slightly peraluminous and similar to topaz-bearing rhyolites. Chondrite-enriched REE patterns exhibit enriched light REE patterns with a negative Eu anomaly (Figure 21). The ore fluids had a $\mathrm{pH}$ of $3-5$, Eh of +0.2 to -0.1 , and a temperature of above $150{ }^{\circ} \mathrm{C}[189]$. 


\subsection{Villa Ahumada Carbonatites, Mexico}

Carbonatites have been found in three areas a few kilometers west of Villa Ahumada in southern Chihuahua, Mexico (Figure 20) [47]. The Yucca, Mariana, and El Indio carbonatites occur as stocks, breccias, and dikes that intrude limestones, granitic intrusions, and rhyolite tuffs. Calcite, Fe-calcite, and hematite are the major minerals found in the carbonatites with minor dolomite, garnet, and other accessory minerals. These carbonatites are mostly classified as calciocarbonatite (sövite) and ferrocarbonatite (Figure 5; according to the classification by 193); magnesio-carbonatites are less abundant. Chondrite-enriched REE patterns exhibit enriched light REE and negative Eu anomaly (Figure 22). Associated igneous rocks include a porphyritic latite dated as $37.00 \pm 0.19 \mathrm{Ma}$ and Crest Tuff dated as $35.61 \pm 0.54 \mathrm{Ma}$. The carbonatite yielded an age of $36.35+0.27 \mathrm{Ma}$ [47]. Detailed mapping and ultimately drilling is required to properly assess the economic potential. The area is currently being examined for REE.

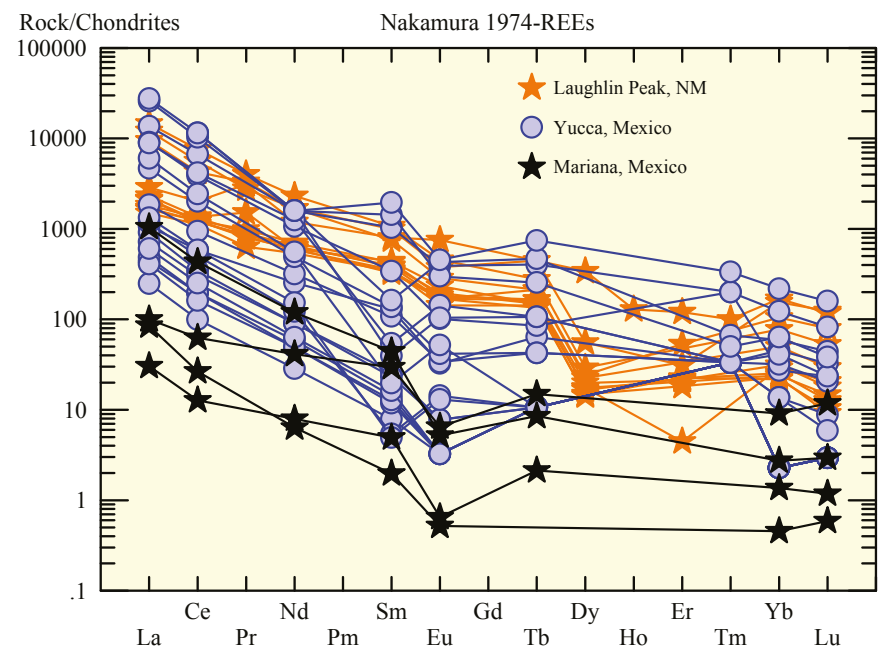

Figure 22. Chondrite-normalized [192] REE plot of carbonatites from Laughlin Peak, New Mexico and Villa Ahumada, Mexico ([47], supplemental material).

\section{Discussion and Conclusions}

\subsection{Age and Geochemistry of Associated Igneous Rocks}

The GPM mineral deposits in New Mexico, Trans-Pecos Texas, and eastern Mexico are associated with Eocene to Oligocene alkaline-igneous rocks and found in small- to medium-sized volcanic fields or porphyry systems, with ages ranging from 22 to $46 \mathrm{Ma}$ (Figure 23; Table 1). The GPM mineral deposits are younger than most alkaline-related REE and gold deposits elsewhere in the North American Cordilleran alkaline-igneous belt (Bear Lodge Mountains, 48-50 Ma [7]). Many of the igneous plutons associated with REE are zoned, whereas plutons and laccoliths associated with gold deposits are small to medium bodies that are not zoned. The igneous rocks in GPM districts are typically subalkaline to alkaline, predominantly metaluminous to peraluminous intrusions, with predominantly linear, light REE-enriched patterns with or without an europium anomaly (Table 1 and references therein). 


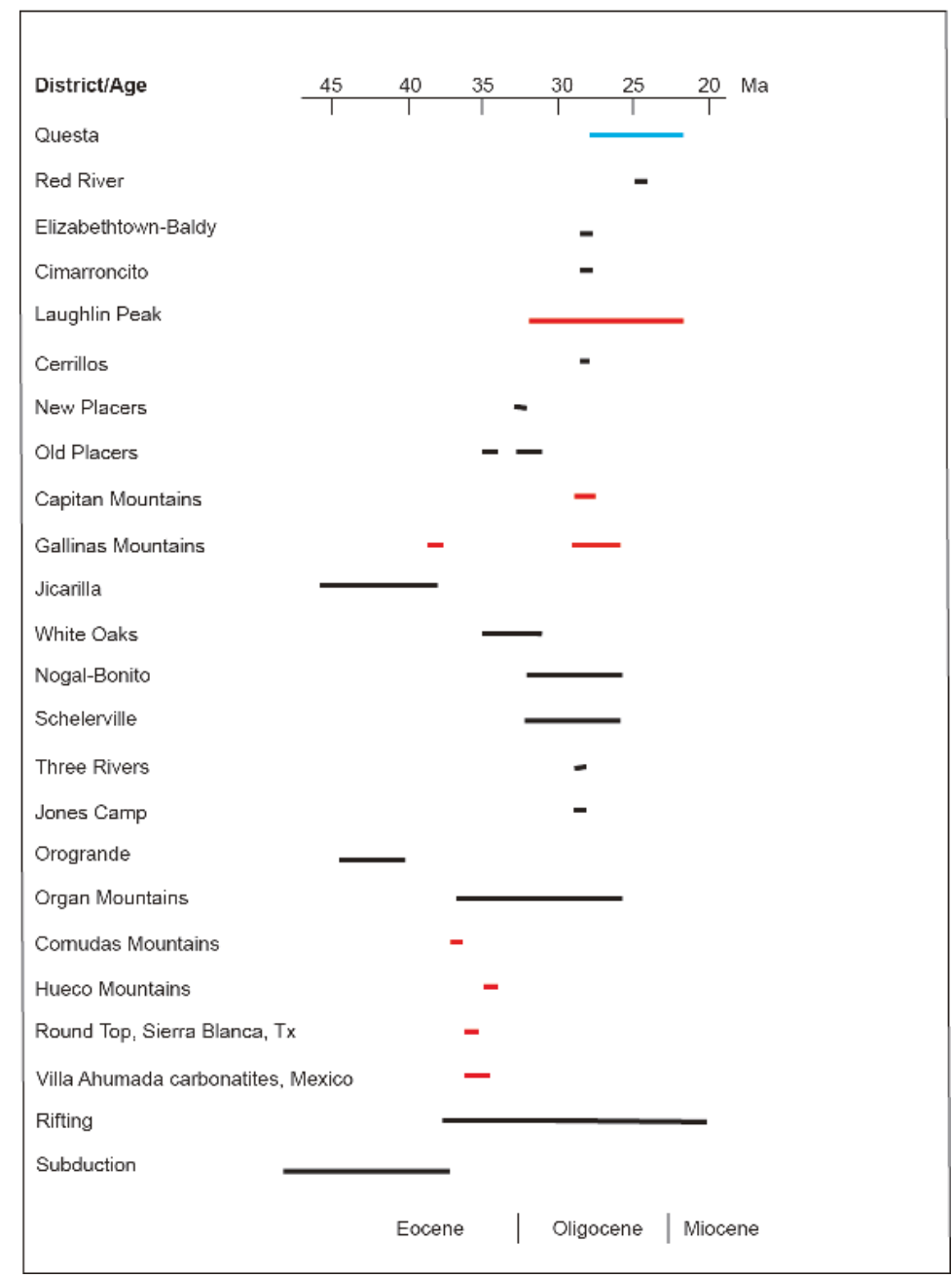

Figure 23. Ages of igneous rocks associated with GPM districts in New Mexico, Texas, and eastern Mexico, arranged from north to south. Ages and references are cited in Table 1. Districts are located in Figures 2 and 20. Blue line represents predominantly porphyry molybdenum district, red line represents predominantly REE districts, and the black lines represents predominantly gold districts. Rifting and subduction lines from [52,199]. Basin and range extension is approximately the same age as the rifting. There is a porphyry molybdenum deposit found in the Nogal-Bonito district, but the age is uncertain.

Igneous rocks in three of the GPM districts associated with predominantly REE deposits (Laughlin Peak, Gallinas Mountains, and Cornudas Mountains) are ferroan, alkali-calcic to alkali. Igneous rocks associated with the predominantly gold and molybdenum GPM districts are predominantly ferroan to magnesian, calc-alkalic to alkali-calcic to alkalic. The oldest igneous rocks in gold-rich Jicarilla Mountains and Orogrande district are mostly magnesian (with some ferroan in the Jicarilla Mountains), alkali-calcic to alkalic. Geochemically, the GPM rocks plot as WPG (within-plate granites) to VAG (volcanic arc granites) according to Pearce et al. [57], and active continental margins, according to 
Schandl and Gordon [60]. In contrast, igneous rocks associated with the Colorado Mineral Belt are magnesian, alkali-calcic to calc-alkalic and metaluminous to peraluminous [200].

$\mathrm{Sr}$ and $\mathrm{Nd}$ isotopes of igneous rocks associated with GPM districts are similar, and imply a lower to upper mantle, homogeneous source (Table 4). There are no correlations with age or spatial relationships. Nd isotopes of GPM deposits (epsilon Nd of -0.3 to -5.5 , Table 4 ) are higher than those of igneous intrusions associated with the Colorado Mineral Belt, where a crustal source is envisioned (epsilon Nd of -7 to -9 ) [200,201].

Table 4. Compilation of $\mathrm{Sr}$ and Nd isotopes of some GPM deposits. See Table 1 for reference of the age of the igneous systems. See Figure 2 for locations of areas. These isotopes are similar and imply a similar, lower to upper mantle, homogeneous source.

\begin{tabular}{|c|c|c|c|c|c|}
\hline District ID & Name & Age & Sr Isotopes & $\mathrm{Nd}\left(\mathrm{CHUR}_{\mathrm{T}}\right)$ & Isotope Reference \\
\hline DIS237 & Questa & $22-28$ & $0.7076-0.7069$ & & {$[64]$} \\
\hline DIS020 & Laughlin Peak & $22.8-32.3$ & $0.7044,0.7039-0.7060$ & & [202] \\
\hline DIS019 & Elizabethtown-Baldy & 29.1 & 0.70617 & & [77] \\
\hline DIS092 & Gallinas Mountains & $26.5-29.74$ & 0.7061 & -2.8 & [125] \\
\hline DIS095 & Nogal-Bonito & 26-33 & 0.7067 & -0.3 & [125] \\
\hline DIS091 & Capitan Mountains & 28.3 & 0.70801 & -5 & [125] \\
\hline DIS216 & Jones Camp & 28.88 & 0.70715 & -5.5 & [125] \\
\hline DIS098 & Tecolote Iron & & $0.70490-0.70513$ & & [125] \\
\hline DIS030 & Organ Mountains & $26-36$ & 0.7085 to 0.7060 & -5 & [156] \\
\hline DIS099 & White Oaks & $31.7-34.7$ & 0.70673 & -3.7 & [125] \\
\hline DIS128 & Cornudas Mountains & 36.3 & 0.7041 & & [165] \\
\hline DIS093 & Jicarilla & $39.1-45.6$ & $0.70565-0.70578$ & -4.8 & [125] \\
\hline
\end{tabular}

The similar compositions of GPM igneous rocks (Tables 1 and 4) suggest that the magmas had a similar origin and were produced from similar source regions. Subtle differences are probably related to differences in fractional crystallization, especially of minerals such as garnet, zircon, and apatite, and water-rock interactions accounts for variations in $\mathrm{K}_{2} \mathrm{O}, \mathrm{Na}_{2} \mathrm{O}, \mathrm{Ba}, \mathrm{Rb}$, and $\mathrm{Sr}$. Alternatively, these differences could represent differences in crustal host rocks, especially in areas where crustal xenoliths are common (such as in the Organ pluton [156] and Jicarilla igneous intrusions). Collectively, the geochemical and isotopic data (Tables 1 and 4 ) are consistent with the older rocks (Jicarilla Mountains, Orogrande) and Cornudas Mountains having an asthenospheric source and the younger rocks having a source in the lower crust with more contamination from the upper crust.

The youngest ages of igneous rocks associated with GPM deposits (22-24 Ma) are in northern New Mexico (Questa, Red River, and Laughlin Peak districts). Only three districts have associated igneous rocks older than $36 \mathrm{Ma}$ (Old Placers, Jicarilla, and Orogrande districts) and they are in central and southern New Mexico. Note that intrusions in the Tecolote and Duran districts remain undated.

Detailed ${ }^{40} \mathrm{Ar} /{ }^{39} \mathrm{Ar}$ studies in several districts suggest tighter constraints in timing of magmatic activity, emphasizing the need for additional detailed ${ }^{40} \mathrm{Ar} /{ }^{39} \mathrm{Ar}$ and $\mathrm{U} / \mathrm{Pb}$ geochronological studies. In the Ortiz porphyry belt, detailed ${ }^{40} \mathrm{Ar} /{ }^{39} \mathrm{Ar}$ studies indicate an early calc-alkaline (34.29-35.79 Ma) phase and younger, slightly alkaline (31.68-33.27 Ma) phase [87]. Cross cutting relations at Carache Canyon in the Ortiz porphyry belt suggest that the $31.56-32.20 \mathrm{Ma}{ }^{40} \mathrm{Ar} /{ }^{39} \mathrm{Ar}$ range of ages of adularia is the age of mineralization [87]. The total duration of volcanic and intrusive activity at the Questa caldera was 9.2 m.y., beginning at 28.5 and ending at 19.3 Ma [71]. The Organ caldera complex was emplaced between 36.45 and $36.03 \mathrm{Ma}$, followed by intrusion of exposed post-caldera plutons between 36.1 and $35.7 \mathrm{Ma}$. Reheating events suggest additional unexposed, post-caldera plutons in the Organ Mountains at $34 \mathrm{Ma}, 32-30 \mathrm{Ma}$, and $26 \mathrm{Ma}$, for a total duration of magmatic activity of $10.45 \mathrm{~m}$.y. [157]. Other areas, especially those associated with REE deposits, are shorter periods of magmatic activity (such as the Capitan and Cornudas Mountains). Mineralization appears to be related to magmatic activity as evidenced by field relationships, isotopic data, and fluid inclusion data. The enrichment of beryllium and REE in the Round Top laccolith, Texas was the result of removal of compatible elements 
from the magma chamber by emplacement of earlier igneous intrusions [186], suggesting that the longer duration of magmatic activity enhances the possibility of forming larger REE deposits.

\subsection{Geology, Geochemistry and Style of Mineralization of GPM Districts}

Detailed geologic mapping of several districts in the GPM portion of the North American Cordilleran alkaline-igneous belt have documented evidence of local structural control of intrusive rocks and mineral deposits [78-80,87,108,122,170]. REE deposits are typically found along local faults (Figures 3, 7 and 9). Regional structures such as the Capitan lineament appear to be important [43]. Generally, gold-bearing magmatic-hydrothermal breccia pipes and porphyry deposits are older than Th-REE-fluorite $( \pm \mathrm{U}, \mathrm{Nb})$ epithermal veins and breccias and Fe skarns $[90,108]$. General paragenesis includes early base-metal veins or skarns followed by gold veins and subsequently Th-REE-fluorite $( \pm \mathrm{U}, \mathrm{Nb})$ epithermal veins and breccias $[90,108,136,137]$.

Gold/silver ratios in GPM deposits are generally higher than other deposits in New Mexico and also have high gold/base-metal ratios, unlike other metal deposits in the state $[2,23,24,29,30]$. Geochemical analyses of many samples from GPM districts exhibit low silver, copper, lead, and zinc concentrations (relative to other metal deposits in western New Mexico [29-32]); only deposits in the Cerrillos, Organ and Gallinas Mountains have significant silver, copper, lead, and zinc production [23,24]. Deposits of REE also are found in several GPM districts in New Mexico, Texas, and eastern Mexico (Figure 2, Table 1, Laughlin Peak and Gallinas, Capitan, and Cornudas Mountains, Sierra Blanca, Mexican carbonatites), but are typically not found with significant gold deposits, although trace amounts of gold are locally present $[24,82,102,104,108,119,168]$. The most significant REE deposits in terms of future potential are found throughout the GPM belt and show no common location, age or composition characteristics.

In New Mexico, the style of mineralization differs from that found in Colorado. Fluorine and gold are common in both areas. Tellurium is found in most of the Colorado districts, but most GPM districts in New Mexico have tungsten and iron skarns, with only trace amounts to no tellurium $[4,26,31,32]$. Carbonatites are only found in New Mexico and Mexico. Iron skarns with local concentrations of gold and REE are found in many GPM districts in New Mexico (Table 1 [62]) and most are associated with elevated REE and gold. However, in Texas and eastern Mexico, tellurium, tungsten and iron skarns are absent. However, tellurium analyses of samples from the GPM districts are limited and tellurium could be found in specific mineralizing zones within New Mexico, Texas, and eastern Mexico districts. More detail mapping and mineral and chemical analyses are required.

\subsection{Origin of GPM Deposits}

These new studies have not resolved the origin of the alkaline-igneous complexes nor the associated mineral deposits, but have provided a better understanding of their origin and provide insights beneficial for exploration. Supporting evidence for a magmatic-hydrothermal origin of GPM mineral deposits include the following: (1) fluid inclusion data, age determinations, and stable isotopic evidence from the Capitan quartz veins [122,126-128] and Nogal-Bonito deposits [136-138,140], (2) nature of stockwork molybdenum deposits at Sierra Blanca [131], (3) close spatial association of the nine types of deposits with igneous rocks $[44,108,125],(4)$ presence of skarn deposits along the contacts of the igneous rocks $[44,108]$, (5) similar age determinations between igneous intrusions and associated mineralization and alteration [23,24], (6) geochemistry, fluid inclusion and geochemical modeling studies in the Gallinas Mountains district [106-110] and (7) similarity of New Mexico deposits to other deposits at Cripple Creek, Colorado and elsewhere where a magmatic origin is favored [26,35,89,90,201]. GPM are found along a long, linear, cratonic boundary (Great Plains and Rocky Mountains) that has a geologic history spanning hundreds of million years [24,27]. The Rio Grande rift formed in close proximity and parallels this boundary. This cratonic boundary formed a pathway that allowed the generation of alkaline and more silicic magmas and hydrothermal fluids that led to the formation of the GPM deposits. The diversity of igneous rocks, including alkaline-igneous 
rocks, and associated mineral deposits along this boundary suggests that this region is characterized by highly fractionated and differentiated, multiple pulses of mantle-derived magmas evolving to lower crustal magmas related to the subduction of the Farallon plate. The differences in incompatible trace elements, including REE and beryllium, between the different granitic to rhyolite rocks are likely related to either differences in the crustal rocks that were assimilated during magmatic differentiation or by potential minor contamination from crustal sources and/or magma mixing.

The presence of carbonatites is important in understanding the origin of GPM deposits. The carbonatites at Laughlin Peak and in Mexico are best described as carbonatites associated with potassic and sodic plutonic rocks [203]. This type of carbonatites typically represents low-temperature, low-pressure, fractional-crystallization derivatives of diverse alkaline parental magmas derived from metasomatized lithospheric mantle [203-205]. Thus, both upper mantle and lower to upper crustal source rocks are involved in forming GPM deposits, which is supported by the geochemical and isotopic evidence (Tables 1 and 4 ).

Many REE deposits associated with igneous rocks are found in extensional settings where thinning of the crust allows for melting of upper mantle magmas [206]. Several studies have attributed changes in the chemistry and source of the magmas to the tectonic transition between Eocene-early Oligocene subduction (Laramide, 36-75 Ma) and mid-Tertiary extension (20-36 Ma) $[124,199,200]$ that was triggered by changes in the subducting Farallon plate. As the Farallon slab fragmented [166,207], the asthenosphere filled gaps between the sinking slab and overlying lithosphere, producing magmas and thereby accounting for slight differences between chemical compositions of the exposed igneous rocks within the GPM belt. The source regions shifted from asthenosphere (with some minor enrichment or metasomatism) with some contamination from the upper crust during Eocene-early Oligocene to lower crust during the late Oligocene [199]. The alkaline-igneous rocks within the GPM districts are likely derived from partial melting within the lithosphere mantle and lower crust, possibly reflecting metasomatism of the upper mantle $[2,3,24,208]$. Rollback of the Farallon flat slab occurred about 23-37 Ma and resulted in a tremendous pulse of calc-alkaline ignimbrite eruptions in southwestern New Mexico and central Mexico west of the GPM deposits [50,52,207].

Deep-seated fracture systems or crustal lineaments probably channeled the magmas and hydrothermal fluids [43]. Once magmas and metal-rich fluids reached shallow levels, local structures and wall rock compositions determined distribution of and final style of intrusions and resulting mineral deposits.

\section{Resources and Future Exploration Potential}

Although a few alkaline-related mineral deposits are large (like Cripple Creek gold deposit and Bear Lodge Mountains REE deposit) [209], most of the GPM deposits are quite small [24], although most in New Mexico, west Texas, and eastern Mexico have not been explored at depth. However, the repetitive occurrence of carbonatites with Th-REE-fluorite $( \pm \mathrm{U}, \mathrm{Nb})$ vein deposits suggests that similar REE-rich carbonatites are likely in the subsurface of some of these systems, which could be indicative of larger REE deposits [7]. The presence of iron skarns containing minor amounts of gold and REE could also be an indicator of additional REE deposits in the subsurface. The lack of abundant quartz in these systems results in these deposits being less resistant to erosion, being covered, and not as well exposed as other types of quartz-rich deposits [209], therefore requiring detailed mapping, geochemical and geophysical studies and ultimately drilling to properly define their extent.

Gold and molybdenum resources in New Mexico have been summarized before [24,31,32,62]. There is REE potential in Th-REE-fluorite $( \pm \mathrm{U}, \mathrm{Nb})$ epithermal veins and breccias in the Laughlin Peak, Gallinas Mountains, Capitan Mountains, Cornudas Mountains, Round Top, and Villa Ahumada districts $[8,19,47]$ and exploration, including drilling, has recently occurred in the Gallinas Mountains, Cornudas Mountains, Round Top, and Villa Ahumada areas. In 1991-1992, U.S. Bureau of Mines calculated an inferred resource of 0.487 million metric tons of total REE (grade of $2.95 \%$ total REE) in the Gallinas Mountains district [105]. The Round Top Mountain, Sierra Blanca, Texas, contains an 
estimated 231.0 Mt of rare-earth mineral resources at the Measured level, with an average grade of $0.06 \mathrm{wt} \%$ total rare-earth oxide (TREO), $298.0 \mathrm{Mt}$ of resources at the Indicated level, with an average grade of $0.06 \%$ TREO, and an estimated $377.0 \mathrm{Mt}$ of resources at the Inferred level, with an average grade of $0.06 \%$ TREO $[8,180,185]$. Since the model for peralkaline intrusion-related REE deposits (USGS model no. $11[8,39,41])$ is now better understood, those peralkaline-igneous rocks in GPM districts (Table 1) and those found in the Tran-Pecos belt [165,166,179], many without any surface indications of mineral deposits, should be re-examined for REE, gold, and other critical elements deposits, requiring detailed mapping and geochemical studies in most areas. In addition, some of the GPM districts could have potential for other critical elements (as defined by [10]), such as fluorine, zirconium, scandium, niobium, gallium, beryllium and tellurium.

Supplementary Materials: The following are available online at http://www.mdpi.com/2079-9276/7/1/8/s1, Table S1. Chemical analyses of igneous and mineralized rocks. Major elements are in weight percent. Trace elements are in ppm, except for Au which is in ppb.

Acknowledgments: This report is part of on-going studies of mineral resources and the geology of carbonatites and alkaline-igneous rocks in New Mexico, supported and funded by the New Mexico Bureau of Geology and Mineral Resources, Nelia Dunbar, Director and State Geologist. I would like to thank many colleagues who contributed to and reviewed manuscripts over the years much of this work is based upon, especially Robert North, Felix Mutschler, Karen Kelley, Steve Ludington, and Miles Silverman. Many graduate studies provided boots-on-the-ground in many of these districts that I have summarized and their work is greatly appreciated. The New Mexico Geological Society funded portions of the graduate students work. Visits to the Mexican deposits were made possible in 1997 by Steve Ludington of the USGS and members of the Consejo de Recursos Minerales (funded by the USGS). Matt Heizler, Lisa Peters and Rich Esser carried out the mineral separations and ${ }^{40} \mathrm{Ar} /{ }^{39} \mathrm{Ar}$ age determinations at the New Mexico Geochronology Laboratory at the New Mexico Bureau of Geology and Mineral Resources over the years and their help in understanding the temporal relationships of the mineral deposits is appreciated. Special thanks to two anonymous reviewers who provided thoughtful comments. Finally, I thank my husband, James McLemore, for his assistance in the field and patience while working on these projects.

Author Contributions: The author contributed the literature search, field mapping, chemical data, mineralogical data and interpretation and writing of the text.

Conflicts of Interest: The author declares no conflict of interest.

\section{References}

1. Lindgren, W. Mineral Deposits, 4th ed.; McGraw-Hill: New York, NY, USA, 1913; 930p.

2. Mutschler, F.E.; Griffin, M.E.; Stevens, D.S.; Shannon, S.S., Jr. Precious metal deposits related to alkaline rocks in the North American Cordillera-An interpretive review. Trans. Geol. Soc. Am. 1985, 88, 355-377.

3. Mutschler, F.E.; Mooney, T.C.; Johnson, D.C. Precious metal deposits related to alkaline igneous rocks-a space-time trip through the Cordillera. Miner. Eng. 1991, 43, 304-309.

4. McLemore, V.T. Tellurium Deposits in New Mexico: SME Annual Meeting Preprint 13-104. Littleton, CO, USA, 2013. Available online: http://geoinfo.nmt.edu/staff/mclemore/projects/ mineralresources/documents/13-104.pdf (accessed on 20 January 2018).

5. Kelley, K.D.; Sry, P.G. Critical Elements in Alkaline Igneous Rock-Related Epithermal Gold Deposits: Chapter 9 InRare Earth and Critical Elements in Ore Deposits; Reviews in Economic Geology 18; Verplanck, P.L., Hitzman, M.W., Eds.; Society of Economic Geologists: Littleton, CO, USA, 2016; pp. 195-216.

6. Maehl, W.C. Zortman and Landusky with 20/20 Hindsight. 2000. Available online: https:// fs.ogm.utah. gov/pub/MINES/AMR_Related/NAAMLP/EnDesign/Maehl.pdf (accessed on 20 January 2018).

7. Millonig, L.J.; Groat, L.A. Carbonatites in western North America-Occurrences and metallogeny. In Tectonics, Metallogeny, and Discovery: The North American Cordillera and Similar Accretionary Settings; Special Publication 17; Colpron, M., Bissig, T., Rusk, B.G., Thompson, J.F.H., Eds.; Society of Economic Geologists: Littleton, CO, USA, 2013; pp. 245-264.

8. Van Gosen, B.S.; Verplanck, P.L.; Seal, R.R., II; Long, K.R.; Gambogi, J. Rare-earth elements, chap. O. In Critical Mineral Resources of the United States-Economic and Environmental Geology and Prospects for Future Supply; U.S. Geological Survey Professional Paper 1802; Schulz, K.J., DeYoung, J.H., Jr., Seal, R.R., II, Bradley, D.C., Eds.; United States Geological Survey: Reston, VA, USA, 2017; pp. O1-O31. 
9. Du, X.; Graedel, T.E. Global in-use stocks of the rare earth elements: A first estimate. Environ. Sci. Technol. 2011, 45, 4096-4101. [CrossRef] [PubMed]

10. Schulz, K.J.; De Young, J.H., Jr.; Bradley, D.C.; Seal, R.R., II. Critical mineral resources of the United States-An introduction, chap. A. In Critical Mineral Resources of the United States-Economic and Environmental Geology and Prospects for Future Supply; Professional Paper 1802; Schulz, K.J., DeYoung, J.H., Jr., Seal, R.R., II, Bradley, D.C., Eds.; U.S. Geological Survey: Reston, VA, USA, 2017; pp. A1-A14.

11. Naumov, A.V. Review of the world market of rare-earth metals. Russ. J. Non-Ferrous Met. 2008, 49, 14-22.

12. Committee on Critical Mineral Impacts of the U.S. Economy. Minerals, Critical Minerals, and the U.S. Economy: Committee on Earth Resources; National Research Council: Washington, DC, USA, 2008; 264p, ISBN 0-309-11283-4.

13. Hedrick, J.B. Rare Earths (Advanced Release): 2007 Minerals Yearbook; U.S. Geological Survey: Reston, VA, USA, 2009; 20p. Available online: http://www.usmagneticmaterials.com/documents/USGS-RE-MineralsYearbook.pdf (accessed on 22 January 2018).

14. Haxel, G.B.; Hedrick, J.B.; Orris, G.J. Rare Earth Elements_Critical Resources for High Technology; Fact Sheet; U.S. Geological Survey: Reston, VA, USA, 2002.

15. Guyonnet, D.; Planchon, M.; Rollat, A.; Escalon, V.; Tuduri, J.; Charles, N.; Vaxelaire, S.; Didier, D.; Fargier, H. Material flow analysis applied to rare earth elements in Europe. J. Clean. Prod. 2015, 107, 215-228. [CrossRef]

16. Chakhmouradian, A.R.; Wall, F. Rare earth elements: Minerals, mines, magnets (and more). Elements 2012, 8, 333-340. [CrossRef]

17. McLemore, V.T.; North, R.M.; Leppert, S. Rare-earth elements (REE), niobium and thorium districts and occurrences in New Mexico. In New Mexico Bureau of Mines and Mineral Resources; Open-file Report OF-324; AGI: Harrisburg, PA, USA, 1988; 28p.

18. McLemore, V.T.; North, R.M.; Leppert, S. Rare-earth elements (REE) in New Mexico. N. M. Geol. 1988, 10, 33-38.

19. Long, K.R.; van Gosen, B.S.; Foley, N.K.; Cordier, D. The Principle Rare Earth Elements Deposits of the United States-A Summary of Domestic Deposits and a Global Perspective; Scientific Investigations Report 2010-5220; U.S. Geological Survey: Reston, VA, USA, 2010.

20. Bonham, H.F., Jr. Models for volcanic-hosted epithermal precious metal deposits. In Bulk Mineable Precious Metal Deposits of the Western United States; Geological Society of Nevada: Reno, NV, USA, 1988; pp. 259-271.

21. Thompson, T.B. Genesis of gold associated with alkaline igneous rocks (abstr.). Geol. Soc. Am. Abstr. Programs 1991, 23, 99-100.

22. Richards, J.P. Magmas, fluids, and ore deposits. In Alkalic-Type Epithermal Gold Deposits-A Review; Short Course Series; Thompson, J.F.H., Ed.; Mineralogical Association of Canada: Québec City, QC, Canada, 1995; Volume 23, pp. 367-400.

23. McLemore, V.T. Great Plains Margin (alkalic-related) gold deposits in New Mexico. In Geology and Ore Deposits of the American Cordillera; Cyner, A.R., Fahey, P.L., Eds.; Geological Society of Nevada: Reno/Sparks, NV, USA, 1996; pp. 935-950.

24. McLemore, V.T. Great Plains Margin (alkaline-related) gold deposits in New Mexico: Twenty years later. In New Concepts and Discoveries, 2015 Symposium Volume; Geological Society of Nevada: Reno/Sparks, NV, USA, 2015; Volume II, pp. 1305-1328.

25. Jensen, E.P.; Barton, M.D. Gold Deposits Related to Alkaline Magmatism; Society of Economic Geologists: Littleton, CO, USA, 2000; Volume 13, pp. 279-314.

26. Kelley, K.D.; Luddington, S. Cripple creek and other alkaline-related gold deposits in the southern Rocky Mountains, USA: Influence of regional tectonics. Miner. Depos. 2002, 37, 38-60. [CrossRef]

27. Chapin, C.E.; Kelley, S.A.; Cather, S.M. The Rocky Mountain front, southwestern USA. Geosphere 2014, 10, 1043-1060. [CrossRef]

28. Potter, L.S. Chemical variation along strike in feldspathoidal rocks of the eastern alkali belt, Trans-Pecos magmatic province, Texas and New Mexico. Can. Miner. 1996, 34, 241-264.

29. North, R.M.; McLemore, V.T. Silver and Gold Occurrences in New Mexico; Resource Map 15; Scale 1:1,000,000; New Mexico Bureau of Mines and Mineral Resources: Socorro, NM, USA, 1986; 32p. 
30. North, R.M.; McLemore, V.T. A Classification of the Precious Metal Deposits of New Mexico. In Bulk Mineable Precious Metal Deposits of the Western United States Symposium Volume, Proceedings of the Geological Society of Nevada, Reno, Nevada, 6-8 April 1987; Geological Society of Nevada: Reno/Sparks, NV, USA, 1988; pp. 625-660.

31. McLemore, V.T. Silver and Gold Resources in New Mexico; Resource Map 21; New Mexico Bureau of Mines and Mineral Resources: Socorro, NM, USA, 2001; 60p.

32. McLemore, V.T.; Lueth, V. Metallic Mineral Deposits. In Energy and Mineral Deposits in New Mexico; McLemore, V.T., Timmons, S., Wilks, M., Eds.; New Mexico Bureau of Geology and Mineral Resources Memoir 50 and New Mexico Geological Society Special Publication: Socorro, NM, USA, 2017; Volume 13, 79p.

33. Cox, D.P.; Bagby, W.C. Descriptive models of Au-Ag-Te veins. In Mineral Deposit Models: U.S. Geological Survey, Bulletin 1693; Cox, D.P., Singer, D.A., Eds.; U.S. Geological Survey: Reston, VA, USA, 1986; p. 124.

34. Bliss, J.D.; Sutphin, D.M.; Moiser, D.L.; Allen, M.S. Grade-tonnage and Target-area Models of Au-Ag-Te Veins Associated with Alkalic Rocks; OF 92-208; U.S. Geological Survey: Reston, VA, USA, 1992; 15p.

35. Kelley, K.D.; Romberger, S.B.; Beaty, D.W.; Pontius, J.A.; Snee, L.W.; Stein, H.J.; Thompson, T.B. Geochemical and geochronological constraints on the genesis of Au-Te deposits at Cripple Creek, Colorado. Econ. Geol. 1998, 93, 981-1012. [CrossRef]

36. Fulp, M.S.; Woodward, L.A. Mineral deposits of the New Mexico alkalic province (abstr.). Geol. Soc. Am. Abstr. Programs 1991, 23, 23.

37. Fulp, M.S.; Woodward, L.A. The Mudpuppy-Waterdog Prospect, an Alkalic Copper-Gold Porphyry System in the NOGAL-Bonito Mining District; Guidebook 42; New Mexico Geological Society: Socorro, NM, USA, 1991; pp. 327-328.

38. Thompson, T.B. The Bonito-Nogal district, Lincoln County, New Mexico (abstr.). Geol. Soc. Am. Bull. Abstr. Programs 1991, 23, 99.

39. Cox, D.P.; Singer, D.A. (Eds.) Mineral Deposit Models; Bulletin 1693; U.S. Geological Survey: Reston, VA, USA, 1986; 379p.

40. Rytuba, J.J.; Cox, D.P. Porphyry Gold: A Supplement to U.S. Geological Survey Bulletin 1693; Open-File Report 91-116; U.S. Geological Survey: Reston, VA, USA, 1991; 7p. Available online: http://pubs.usgs.gov/of/ 1991/0116/report.pdf (accessed on 20 January 2018).

41. Verplanck, P.L.; Van Gosen, B.S.; Seal, R.R.; McCafferty, A.E. A Deposit Model for Carbonatite and Peralkaline Intrusion-Related Rare Earth Element Deposits: Chapter J in Mineral Deposit Models for Resource Assessment; Scientific Investigations Report 2010-5070-J; U.S. Geological Survey: Reston, VA, USA, 2014; 58p.

42. Foley, N.K.; Hofstra, A.H.; Lindsey, D.A.; Seal, R.R., II; Jaskula, B.; Piatak, N.M. Occurrence model for volcanogenic beryllium deposits, chap. F. In Mineral Deposit Models for Resource Assessment; Scientific Investigations Report 2010-5070-F; U.S. Geological Survey: Reston, VA, USA, 2012; 43p.

43. McLemore, V.T.; Zimmerer, M. Magmatic Activity and Mineralization along the Capitan; In Santa Rita, and Morenci Lineaments in the Chupadera Mesa Area, Central New Mexico. Guidebook 60; New Mexico Geological Society: Socorro, NM, USA, 2009; pp. 375-386.

44. McLemore, V.T. Geology and Mineral Resources of the Laughlin Peak Mining District; Guidebook 66; New Mexico Geological Society: Socorro, NM, USA, 2015; pp. 277-288.

45. McLemore, V.T.; Dunbar, N.; Heizler, L.; Heizler, M. Geology and Mineral Deposits of the Orogrande Mining District; Guidebook 65; New Mexico Geological Society: Socorro, NM, USA, 2014; pp. 247-259.

46. McLemore, V.T.; Phillips, R.S. Geology of Mineralization and Associated Alteration in the Capitan Mountains; Guidebook 42; New Mexico Geological Society: Socorro, NM, USA, 1991; pp. 291-298.

47. Nandigam, R. Geology and Geochemistry of Newly Discovered Tertiary Carbonatite Occurrences near Villa Ahumada Area, Basin and Range Province, Chihuahua, Northern Mexico. Ph.D. Thesis, University of Texas at El Paso, El Paso, TX, USA, 2000.

48. McLemore, V.T. Rare Earth Elements Deposits in New Mexico. In Arizona Geological Survey Special Paper \#9; Chapter 3, Proceedings of the 48th Annual Forum on the Geology of Industrial Minerals, Phoenix, Arizona, 30 April-4 May 2012; Conway, F.M., Ed.; 2014; pp. 1-16. Available online: http://repository.azgs.az.gov/uri_ gin/azgs/dlio/1568 (accessed on 20 January 2018).

49. Woolley, A.R. Alkaline Rocks and Carbonatites of the World, Part 1: North and South America; University of Texas Press: Austin, TX, USA, 1987. 
50. Chapin, C.E.; Jahns, R.H.; Chamberlin, R.M.; Osburn, G.R. First day road log from Socorro to Truth or Consequences via Magdalena and Winston. In Field Guild to Selected Caldrons and Mining Districts of the Datil-Mogollon Volcanic Field, New Mexico; Special Publication No. 7; New Mexico Geological Society: Socorro, NM, USA, 1978; pp. 17-19.

51. Sims, P.K.; Stein, H.J.; Finn, C.A. New Mexico structural zone-An analogue of the Colorado mineral belt. Ore Geol. Rev. 2002, 21, 211-225. [CrossRef]

52. Chapin, C.E.; Wilks, M.; McIntosh, W.C. Space-Time Patterns of Late Cretaceous to Present Magmatism in New Mexico; Comparison with Andean Volcanism and Potential for Future Volcanism; InTectonics, Geochronology and Volcanism in the Southern Rocky Mountains and Rio Grande rift: New Mexico Bureau of Geology and Mineral Resources; Bulletin 160; Socorro, NM, USA, 2004; pp. 13-40. Available online: http:/ /geoinfo.nmt. edu/publications/monographs/bulletins/160/downloads/02chapin.pdf (accessed on 20 January 2018).

53. McLemore, V.T.; Hoffman, G.; Smith, M.; Mansell, M.; Wilks, M. Mining Districts of New Mexico; Open-file Report [CD-ROM]; New Mexico Bureau of Mines and Mineral Resources: Socorro, NM, USA, 2005.

54. McLemore, V.T.; Krueger, C.B.; Johnson, P.; Raugust, J.S.; Jones, G.E.; Hoffman, G.K.; Wilks, M. New Mexico Mines Database. Miner. Eng. 2005, 27, 42-49.

55. File, L.; Northrop, S.A. County, Township, and Range Locations of New Mexico's Mining Districts; Circular 84; New Mexico Bureau of Mines and Mineral Resources: Socorro, NM, USA, 1966; 66p.

56. Irvine, T.N.; Baragar, W.R.A. A guide to the chemical classification of the common volcanic rocks. Can. J. Earth Sci. 1971, 8, 523-548. [CrossRef]

57. Pearce, J.A.; Harris, N.B.W.; Tindle, A.G. Trace element discrimination diagrams for the tectonic interpretation of granitic rocks. J. Petrol. 1984, 24, 956-983. [CrossRef]

58. Frost, B.D.; Barnes, C.G.; Collins, W.J.; Arculus, R.J.; Ellis, D.J.; Frost, C.D. A geochemical classification for granitic rocks. J. Petrol. 2001, 42, 2033-2048. [CrossRef]

59. Frost, B.D.; Frost, C.D. A geochemical classification for feldspathic igneous rocks. J. Petrol. 2008, 49, 1955-1969. [CrossRef]

60. Schandl, E.S.; Gorton, M.P. Application of high field strength elements to discriminate tectonic settings in VMS environments. Econ. Geol. 2002, 97, 629-642. [CrossRef]

61. Whalen, J.B.; Currie, K.L.; Chappell, B.W. A-Type granites: Geochemical characteristics, discrimination and petrogenesis. Contrib. Miner. Petrol. 1987, 95, 407-419. [CrossRef]

62. McLemore, V.T. Mining Districts and Prospect Areas of New Mexico; Resource Map 24; Scale 1:1,000,000; New Mexico Bureau of Geology and Mineral Resources: Socorro, NM, USA, 2017; 65p.

63. Lipman, P.W. Incremental assembly and prolonged consolidation of Cordilleran magma chambers: Evidence from the Southern Rocky Mountain volcanic field. Geosphere 2007, 3, 42-70. [CrossRef]

64. Laughlin, A.W.; Rehrig, W.A.; Mauger, R.L. K-Ar chronology and sulfur and strontium isotope ratios at the Questa mine, New Mexico. Econ. Geol. 1969, 64, 903-909. [CrossRef]

65. Dillet, B.; Czamanske, G.K. Aspects of the Petrology, Mineralogy, and Geochemistry of the Granitic Rocks Associated with Questa Caldera, Northern New Mexico; Open-File Report 87-0258; U.S. Geological Survey: Reston, VA, USA, 1987; 238p.

66. Johnson, C.M.; Czamanske, G.K.; Lipman, P.W. Geochemistry of intrusive rocks associated with the Latir volcanic field, New Mexico, and contrasts between evolution of plutonic and volcanic rocks. J. Contrib. Miner. Petrol. 1989, 103, 90-109. [CrossRef]

67. Czamanske, G.K.; Allen, J.C. The ${ }^{40} \mathrm{Ar} /{ }^{39} \mathrm{Ar}$ Chronology of Caldera Formation, Intrusive Activity and Mo-Ore Deposition Near Questa, New Mexico; InTectonic Development of the Southern Sangre de Cristo Mountains, New Mexico; Guidebook 41; Bauer, P.W., Lucas, S.G., Mawer, C.K., McIntosh, W.C., Eds.; New Mexico Geological Society: Socorro, NM, USA, 1990; pp. 355-358.

68. Ross, P.S.; Jebrak, M.; Walker, B.M. Discharge of hydrothermal fluids from a magma chamber and concomitant formation of a stratified breccia zone at the Questa porphyry molybdenum deposit, New Mexico. Econ. Geol. 2002, 97, 1679-1699. [CrossRef]

69. McLemore, V.T. Geologic Setting and Mining History of the Questa Mine; Open-file report 515; New Mexico Bureau of Geology and Mineral Resources: Socorro, NM, USA, 2009; 29p.

70. Rowe, A. Ore Genesis and Fluid Evolution of the Goat Hill Orebody, Questa Climax-Type Porphyry-Mo System, New Mexico and Its Comparison to the Climax-Type Deposits of the Colorado Mineral Belt. Ph.D. Thesis, New Mexico Institute Mining Technology, Socorro, NM, USA, 2012. 
71. Zimmerer, M.J.; McIntosh, W.C. The geochronology of volcanic and plutonic rocks at the Questa caldera: Constraints on the origin of caldera-related silicic magmas. Geol. Soc. Am. 2012, 124, 1394-1408. [CrossRef]

72. Roberts, T.T.; Parkison, G.A.; McLemore, V.T. Geology of the Red River District, Taos County, New Mexico; Guidebook 41; New Mexico Geological Society: Socorro, NM, USA, 1990; pp. 375-380.

73. Lindgren, W.; Graton, L.C.; Gordon, C.H. The Ore Deposits of New Mexico; Professional Paper 68; U.S. Geological Survey: Reston, VA, USA, 1910; 361p.

74. Lee, W.T. The Aztec Gold Mine, Baldy, New Mexico; Bulletin 620; U.S. Geological Survey: Reston, VA, USA, 1916; pp. 325-330.

75. Pettit, R.F. Mineral Resources of Colfax County, New Mexico; Open-file Report 15; New Mexico Bureau of Mines and Mineral Resources: Socorro, NM, USA, 1946; 73p.

76. Pearson, J.B. A New Mexico Gold Story-The Elizabethtown-Red River area. Ph.D. Thesis, University Texas, Austin, TX, USA, 1955; pp. 1-534.

77. Kish, S.A.; Ragland, P.C.; Cannon, R.P. Petrochemistry of the Palisades Sheet, Cimarron Pluton, Northern New Mexico; Guidebook 41; New Mexico Geological Society: Socorro, NM, USA, 1990; pp. 341-347.

78. Staatz, M.H. Geology and Description of the Thorium and Rare-Earth Veins in the Laughlin Peak Area, Colfax County, New Mexico; Professional Paper 1049-E; U.S. Geological Survey: Reston, VA, USA, 1985; 32p.

79. Staatz, M.H. Geologic Map of the Pine Buttes Quadrangle, Colfax County, New Mexico; Quadrangle Map GQ-1591; Scale 1:24,000; U.S. Geological Survey: Reston, VA, USA, 1986.

80. Staatz, M.H. Geologic Map of the Tres Hermanos Peak Quadrangle, Colfax County, New Mexico; Quadrangle Map GQ-1605; Scale 1:24,000; U.S. Geological Survey: Reston, VA, USA, 1987.

81. Potter, L.S. Petrology and Petrogenesis of Tertiary Igneous Rocks, Chico Hills, New Mexico. Master's Thesis, Iowa State University, Ames, IA, USA, 1988.

82. Schreiner, R.A. Preliminary Investigations of Rare-Earth-Element-Bearing Veins, Breccias, and Carbonatites in the Laughlin Peak Area, Colfax County, New Mexico; U.S. Bureau of Mines: Washington, DC, USA, 1991; pp. 93-99.

83. Stroud, J.R. The Geochronology of the Raton-Clayton Volcanic Field, with Implications for Volcanic History and Landscape Evolution. Master's Thesis, New Mexico Institute of Mining and Technology, Socorro, NM, USA, 1997; pp. 1-70.

84. Wargo, J.G. Geology of a disseminated copper deposit near Cerrillos, New Mexico. Econ. Geol. 1964, 59, 1525-1538. [CrossRef]

85. Giles, D.L. Gold mineralization in the Cerrillos district, New Mexico (abstr.). Geol. Soc. Am. Abstr. Programs 1991, 23, 24.

86. Sauer, R.R. Petrochemistry and Geochronology of Plutons Relative to Tectonics in the San Pedro-Ortiz Porphyry Belt, New Mexico. Master's Thesis, University Colorado, Boulder, CO, USA, 1994.

87. Maynard, S.R. Geology and Mineral Resources of the Ortiz Mine Grant, Santa Fe County, New Mexico; Open-File Report 560; New Mexico Bureau of Geology and Mineral Resources: Socorro, NM, USA, 2014; 178p.

88. Kay, B.D. Vein and Breccia Gold Mineralization and Associated Igneous Rocks at the Ortiz Mine, New Mexic, USA. Master's Thesis, Colorado School of Mines, Golden, CO, USA, 1986.

89. Maynard, S.R.; Martin, K.W.; Nelson, C.J.; Schutz, J.L. Geology and Gold Mineralization of the Ortiz Mountains, Santa Fe County, New Mexico; Preprint No. 89-43; Society of Mining, Metallurgy and Exploration: Littleton, CO, USA, 1989; 9p.

90. Maynard, S.R.; Nelson, C.J.; Martin, K.W.; Schutz, J.L. Geology and gold mineralization of the Ortiz Mountains, Santa Fe County, New Mexico. Miner. Eng. 1990, 42, 1007-1011.

91. Schutz, J.L. Gold Mineralization Associated with Alkaline Intrusives at the Carache Canyon Breccia Pipe Prospect, Ortiz Mountains, New Mexico; Guidebook 46; New Mexico Geological Society: Socorro, NM, USA, 1995; pp. 167-173.

92. Kelley, V.C. Geology and Economics of New Mexico Iron Ore Deposits; University of New Mexico, Publications in Geology: Albuquerque, NM, USA, 1949; 246p.

93. McLemore, V.T. Preliminary Report on the Geology and Mineral-Resource Potential of Torrance County, New Mexico; OF-192; New Mexico Bureau of Mines and Mineral Resources: Socorro, NM, USA, 1984; 211p.

94. Griswold, G.B. Mineral Deposits of Lincoln County, New Mexico; Bulletin 67; New Mexico Bureau of Mines and Mineral Resources: Socorro, NM, USA, 1959; pp. 1-117.

95. Glass, J.J.; Smalley, R.G. Bastnaesite (Gallinas Mountains, New Mexico). Am. Miner. 1945, 30, 601-615. 
96. Kelley, V.C.; Rothrock, H.E.; Smalley, R.G. Geology and Mineral Deposits of the Gallinas District, Lincoln County, New Mexico; Strategic Minerals Investigation Preliminary Map 3-211; Scale 1:62,500; U.S. Geological Survey: Reston, VA, USA, 1946.

97. Soulé, J.H. Exploration of Gallinas Fluorspar Deposits, Lincoln County, New Mexico; Report of Investigations 3854; U.S. Bureau of Mines: Washington, DC, USA, 1946; 25p.

98. Perhac, R.M. Geology and Mineral Deposits of the Gallinas Mountains, New Mexico. Ph.D. Thesis, University of Michigan, Ann Arbor, Michigan, 1961.

99. Perhac, R.M. Geology and Mineral Deposits of the Gallinas Mountains, Lincoln and Torrance Counties, New Mexico; Bulletin 95; New Mexico Bureau of Mines and Mineral Resources: Socorro, NM, USA, 1970; 51p.

100. Perhac, R.M.; Heinrich, E.W. Fluorite-bastnaesite deposits of the Gallinas Mountains, New Mexico and bastnaesite paragenesis. Econ. Geol. 1964, 59, 226-239. [CrossRef]

101. DeMark, R.S. The Red Cloud mines, Gallinas Mountains, New Mexico. Miner. Rec. 1980, 11, 69-72.

102. Korzeb, S.L.; Kness, R.F. Mineral Resource Investigation of the Roswell Resource Area, Chavez, Curry, DeBaca, Guadalupe, Lincoln, Quay and Roosevelt Counties, New Mexico; Open-file Report MLA 12-92; U.S. Bureau of Mines: Washington, DC, USA, 1992; 220p.

103. Woodward, L.A.; Fulp, M.S. Gold Mineralization Associated with Alkali Trachyte Breccias in the Gallinas Mining District, Lincoln County, New Mexico; Guidebook 42; New Mexico Geological Society: Socorro, NM, USA, 1991; pp. 323-325.

104. Schreiner, R.A. Mineral Investigation of the Rare-Earth-Element-Bearing Deposits, Red Cloud Mining District, Gallinas Mountains, Lincoln County, New Mexico; Open-file Report 2-91; U.S. Bureau of Mines: Washington, DC, USA, 1993; 62p.

105. Jackson, W.D.; Christiansen, G. International Strategic Minerals Inventory Summary Report-Rare-Earth Oxides; Circular 930-N; U.S. Geological Survey: Reston, VA, USA, 1993; 76p.

106. Williams-Jones, A.E.; Samson, I.M.; Olivo, G.R. The genesis of hydrothermal fluorite-REE deposits in the Gallinas Mountains, New Mexico. Econ. Geol. 2000, 95, 327-341. [CrossRef]

107. Gagnon, J.E.; Samson, I.M.; Fryer, B.J.; Williams-Jones, A.E. Compositional heterogeneity in fluorite and the genesis of fluorite deposits: Insights from LA-ICP-Ms analysis. Can. Miner. 2003, 41, 365-382. [CrossRef]

108. McLemore, V.T. Geology and Mineral Deposits of the Gallinas Mountains, Lincoln and Torrance Counties, New Mexico; Preliminary Report; Open-File Report OF-532; New Mexico Bureau of Geology and Mineral Resources: Socorro, NM, USA, 2010; 92p.

109. Vance, Z. Mineralogy, Geochemistry and Genesis of the Hydrothermal REE-Fluorite-Ag-Pb-Cu Ore Deposits of the Gallinas Mountains, New Mexico. Master's Thesis, New Mexico Institute of Mining and Technology, Socorro, NM, USA, 2013.

110. Robison, A. ${ }^{40} \mathrm{Ar} /{ }^{39} \mathrm{Ar}$ Geochronology of Magmatism and Alteration in the Gallinas Mountains with Implications for Rare Earth Mineralization. Master's Thesis, New Mexico Institute of Mining and Technology, Socorro, NM, USA, 2017.

111. Robison, A.; McIntosh, W.; Lueth, V.W. ${ }^{40} \mathrm{Ar} /{ }^{39} \mathrm{Ar}$ geochronology of magmatism and alteration in the Gallinas Mountains with implications for rare earth mineralization. In New Mexico Geological Society, Annual Spring Meeting, 7 April 2017; Macey Center, New Mexico Institute Mining Technology: Socorro, NM, USA, 2017; p. 61. Available online: http://nmgs.nmt.edu/meeting/abstracts/view.cfm?aid=540 (accessed on 20 January 2018).

112. Rawson, D.E. Geology of the Tecolote Hills Area, Lincoln County, New Mexico. Master's Thesis, University New Mexico, Albuquerque, NM, USA, 1957.

113. Segerstrom, K.; Ryberg, G.C. Geology and Placer-Gold Deposits of the Jicarilla Mountains, Lincoln County, New Mexico; Bulletin 1308; U.S. Geological Survey: Reston, VA, USA, 1974; 25p.

114. McLemore, V.T.; Ouimette, M.; Eveleth, R.W. Preliminary Observations on the Mining History, Geology and Mineralization of the Jicarilla Mining District, Lincoln County, New Mexico; Guidebook 42; New Mexico Geological Society: Socorro, NM, USA, 1991; pp. 311-316.

115. Grainger, J.R. Geology of the White Oaks Mining District, Lincoln County, New Mexico. Master's Thesis, University New Mexico, Albuquerque, NM, USA, 1974.

116. Ronkos, C.J. Geology, alteration, and gold mineralization in the White Oaks mining district, Lincoln County, New Mexico (abstr.). Geol. Soc. Am. Abstr. Programs 1991, 23, 88. 
117. Koning, D.J.; Kempter, K. Preliminary Geologic Map of the Carrizozo East 7.5-Minute Quadrangle, Lincoln County, New Mexico; Open-File Geologic Map 216; Scale 1:24,000; New Mexico Bureau of Geology and Mineral Resources: Socorro, NM, USA, 2010.

118. Rawling, G.; Koning, D. Geologic Map of the White Oaks South Quadrangle, Lincoln County, New Mexico; Open-File Geologic Map, OF-GM 216; Scale 1:24,000; New Mexico Bureau of Geology and Mineral Resources: Socorro, NM, USA, 2011.

119. Tuftin, S.E. Mineral Investigation of the Capitan Mountains Wilderness Area, Lincoln County, New Mexico; Open-File Report; MLA-20-84; U.S. Bureau Mines: Washington, DC, USA, 1984; 24p.

120. Willis, M.; Campbell, A.; Phillips, R. High salinity fluids associated with allanite mineralization, Capitan Mountains, New Mexico. Geol. Soc. Am. Abstr. Programs 1989, 21, A287.

121. Phillips, R.S. Geochemistry of Hydrothermal Th-U-REE Quartz/Fluorite Veins from the Capitan Pluton. Master's Thesis, New Mexico Institute of Mining and Technology, Socorro, NM, USA, 1990.

122. Phillips, R.S.; Campbell, A.R.; McLemore, V.T. Th-U-REE Quartz-Fluorite Veins, Capitan Pluton, New Mexico: Evidence for a Magmatic-Hydrothermal Origin; Guidebook 42; New Mexico Geological Society: Socorro, NM, USA, 1991; pp. 129-136.

123. Banks, D.A.; Yardley, B.W.D.; Campbell, A.R.; Jarvis, K.E. REE composition of an aqueous magmatic fluid: A fluid inclusion study from the Capitan pluton, New Mexico, USA. Chem. Geol. 1994, 113, 259-272. [CrossRef]

124. Allen, M.S.; McLemore, V.T. The Geology and Petrogenesis of the Capitan Pluton, New Mexico. In Geology of the Sierra Blanca, Sacramento, and Capitan Ranges, New Mexico: New Mexico Geological Society, 42nd Annual Field Conference, Guidebook; Barker, J.M., Kues, B.S., Austin, G.S., Lucas, S.G., Eds.; New Mexico Geological Society: Socorro, NM, USA, 1991; pp. 115-127.

125. Allen, M.S.; Foord, E.E. Geological, geochemical and isotopic characteristics of the Lincoln County porphyry belt, New Mexico: Implications for regional tectonics and mineral deposits. In Geology of the Sierra Blanca, Sacramento, and Capitan Ranges, New Mexico: New Mexico Geological Society, 42nd Annual Field Conference, Guidebook; Barker, J.M., Kues, B.S., Austin, G.S., Lucas, S.G., Eds.; New Mexico Geological Society: Socorro, NM, USA, 1991; pp. 97-113.

126. Campbell, A.R.; Banks, D.A.; Phillips, R.S.; Yardley, B.W.D. Geochemistry of the Th-U-REE mineralizing fluid, Capitan Mountains, New Mexico, USA. Econ. Geol. 1995, 90, 1273-1289. [CrossRef]

127. Ratajeski, K.; Campbell, A.R. Distribution of fluid inclusions in igneous quartz of the Capitan Pluton, New Mexico, USA. Geochim. Cosmochim. Acta. 1994, 58, 1161-1174. [CrossRef]

128. Dunbar, N.W.; Campbell, A.R.; Candela, P.A. Physical, chemical, and mineralogical evidence for magmatic fluid migration within the Capitan pluton, southeastern New Mexico. Geol. Soc. Am. Bull. 1996, 108, 318-333. [CrossRef]

129. Rawling, G.C. Geology of the Capitan and Nogal Quadrangles, Lincoln County, New Mexico; Open-File Report 538; Scale 1:24,000; New Mexico Bureau of Geology and Mineral Resources: Socorro, NM, USA, 2011.

130. Griswold, G.B.; Missaghi, F. Geology and Geochemical Survey of a Molybdenum Deposit near Nogal Peak, Lincoln County, New Mexico; New Mexico Bureau of Mines and Mineral Resources Campus Station: Socorro, NM, USA, 1964; Volume 67, p. 29.

131. Giles, D.L.; Thompson, T.B. Petrology and mineralization of a molybdenum-bearing alkalic stock, Sierra Blanca, New Mexico. Geol. Soc. Am. Bull. 1972, 83, 2129-2148. [CrossRef]

132. Gander, M.J. The Geology of the Northern Part of the Rialto Stock, Sierra Blanca Igneous Complex, New Mexico. Master's Thesis, Colorado State University, Fort Collins, CO, USA, 1982.

133. Briggs, J.P. Mineral Investigation of an Addition to the White Mountain Wilderness, Lincoln County, New Mexico; MLA-33-83; U.S. Bureau of Mines: Washington, DC, USA, 1983; 11p.

134. Ryberg, G.E. Geology of the Vera Cruz Mine and Breccia Pipe, Lincoln County, New Mexico; Guidebook 42; New Mexico Geological Society: Socorro, NM, USA, 1991; pp. 329-332.

135. Douglass, S.E. Characterization of Alkaline Rock-Hosted Precious and Base Metal Mineralization in the Nogal Mining District, Lincoln County, New Mexico. Master's Thesis, New Mexico Institute of Mining and Technology, Socorro, NM, USA, 1992.

136. Douglass, S.E.; Campbell, A.R. Characterization of alkaline rock-related mineralization in the Nogal mining district, Lincoln County, New Mexico. Econ. Geol. 1994, 89, 1306-1321. [CrossRef] 
137. Douglass, S.E.; Campbell, A.R. Characterization of alkaline rock-related mineralization in the Nogal mining district, Lincoln County, New Mexico, Reply. Econ. Geol. 1995, 90, 985-987. [CrossRef]

138. Campbell, A.R.; Porter, J.A.; Scott, E.; Douglass, S.E. Fluid Inclusion Investigation of the Mid-Tertiary Helen Rae Gold Mine, Nogal District, New Mexico; Guidebook 42; New Mexico Geological Society: Socorro, NM, USA, 1991; pp. 317-321.

139. Constantopoulos, J. Geochemistry of the Bonito Lake stock, Lincoln County, New Mexico: Petrogenesis and hydrothermal alteration. Rocky Mt. Geol. 2007, 42, 137-155. [CrossRef]

140. McLemore, V.T.; Goff, F.; McIntosh, W. Geology and Mineral Resources of the Nogal-Bonito Mining District, Lincoln County, New Mexico; Guidebook 65; New Mexico Geological Society: Socorro, NM, USA, 2014; pp. 235-246.

141. Goff, F.; Kelley, S.A.; Lawrence, J.R.; Cikiski, C.; Krier, D.J.; Goff, C.J.; McLemore, V.T. Preliminary Geologic Map of the Nogal Peak Quadrangle, Lincoln and Otero Counties, New Mexico; Open-File Geologic Map OF-GM-134; New Mexico Bureau of Geology and Mineral Resources: Socorro, NM, USA, 2011; 81p.

142. Goff, F.; Roback, R.C.; McIntosh, W.I.; Goff, C.J.; Kluk, E.C. Geochemistry and Geochronology of Intrusive and Volcanic Rocks of the Three Rivers Stock, Sierra Blanca, New Mexico; Guidebook 65; New Mexico Geological Society: Socorro, NM, USA, 2014; pp. 183-196.

143. Kelley, S.; Koning, D.J.; Goff, F.; Cikoski, C.; Peters, L.; McIntosh, W. Stratigraphy of the Northwestern Sierra Blanca Volcanic Field; Guidebook 65; New Mexico Geological Society: Socorro, NM, USA, 2014; pp. 197-208.

144. Cikoski, C.T.; Koning, D.J.; Kelley, S.A.; Zeigler, K.E. Preliminary Geologic Map of the Church Mountain Quadrangle, Lincoln County, New Mexico; Open-File Geologic Map OF-GM-215; Scale 1:24,000; New Mexico Bureau of Geology and Mineral Resources: Socorro, NM, USA, 2011.

145. McLemore, V.T. Geology of the Three Rivers Mining District; Guidebook 65; New Mexico Geological Society: Socorro, NM, USA, 2014; pp. 45-47.

146. Chamberlin, R.M.; McIntosh, W.C.; Peters, L. ${ }^{40} A r /{ }^{\beta 9} A r$ Geochronology of the Jones Camp Dike, Central New Mexico: An Eastward Projection of the Magdalena Radial Dike Swarm from under the Oligocene Socorro-Magdalena Caldera Cluster; Guidebook 60; New Mexico Geological Society: Socorro, NM, USA, 2009; pp. 337-346.

147. Aldrich, M.J., Jr.; Chapin, C.E.; Laughlin, A.W. Stress history and tectonic development of the Rio Grande Rift, New Mexico. J. Geophys. Res. 1986, 91, 6199-9211. [CrossRef]

148. North, R.M. Geology and Ore Deposits of the Orogrande Mining District, Otero County, New Mexico; OF-370; New Mexico Bureau of Mines and Mineral Resources: Socorro, NM, USA, 1982; 23p.

149. Seager, W.R. Geology of the Organ Mountains and Southern San Andres Mountains, New Mexico; Memoir 36; New Mexico Bureau of Mines and Mineral Resources: Socorro, NM, USA, 1981; 97p.

150. Seager, W.R.; McCurry, M. The cogenetic Organ cauldron and batholith, south-central New Mexico: Evolution of a large-volume ash-flow cauldron and its source magma chamber. J. Geophys. Res. 1988, 93, 4421-4433. [CrossRef]

151. Newcomer, R.W., Jr.; Giordano, T.H. Porphyry-type mineralization and alteration in the Organ mining district, south-central New Mexico. N. M. Geol. 1986, 8, 83-86.

152. McLemore, V.T.; Sutphin, D.M.; Hack, D.R.; Pease, T.C. Mining History and Mineral Resources of the Mimbres Resource Area, Doña Ana, Luna, Hidalgo, and Grant Counties, New Mexico; Open-File Report 424; New Mexico Bureau of Mines and Mineral Resources: Socorro, NM, USA, 1996; 251p.

153. Lueth, V.W. Tellurium Mineralization in the Northern Organ District, Dona Ana County, New Mexico; Guidebook 49; New Mexico Geological Society: Socorro, NM, USA, 1998; pp. 265-269.

154. Lueth, V.W.; McLemore, V.T. A Reinterpretation of Ore Zoning in the Organ District, Doña Ana County, New Mexico; Guidebook 49; New Mexico Geological Society: Socorro, NM, USA, 1998; pp. 279-285.

155. Verplanck, P.L.; Farmer, G.L.; McCurry, M.; Mertzman, S.; Snee, L.W. Isotopic evidence on the origin of compositional layering in an epizonal magma body. Earth Planet. Sci. Lett. 1995, 136, 31-41. [CrossRef]

156. Verplanck, P.L.; Farmwe, G.L.; McCurry, M.; Mertzman, S.A. The chemical and isotopic differentiation of an epizonal magma body: Organ Needle pluton, New Mexico. J. Petrol. 1999, 40, 653-678. [CrossRef]

157. Zimmerer, M.J.; McIntosh, W.C. Geochronologic evidence of upper-crustal in situ differentiation: Silicic magmatism at the Organ caldera complex, New Mexico. Geosphere 2013, 9, 155-169. [CrossRef]

158. Zapp, A.D. Geology of the Northeastern Cornudas Mountains, New Mexico. Master's Thesis, University of Texas at Austin, Austin, TX, USA, 1941. 
159. Clabaugh, S.E. Geology of the Northwestern Portion of the Cornudas Mountains, New Mexico. Master's Thesis, University of Texas at Austin, Austin, TX, USA, 1941.

160. Timm, B.C. The Geology of the Southern Cornudas Mountains, Texas and New Mexico, Master's Thesis, University of Texas at Austin, Austin, TX, USA, 1941.

161. Clabaugh, S.E. Eudialyte and eucolite from southern New Mexico (abstr.). Am. Miner. 1950, 35, $279-280$.

162. Collins, G.E. Preliminary Reconnaissance for Uranium in the Cornudas Mountains, Otero County, New Mexico and Hudspeth County, Texas; Report DBO-4-TM-5; U.S. Atomic Energy Commission: Washington, DC, USA, 1958; 16p.

163. Warner, L.A.; Holser, W.T.; Wilmarth, V.R.; Cameron, E.N. Occurrence of Nonpegmatite Beryllium in the United States; Professional Paper; U.S. Geological Survey: Reston, VA, USA, 1959; Volume 318, 198p.

164. Barker, D.S.; Hodges, F.N. Mineralogy of intrusions in the Diablo Plateau, northern Trans-Pecos magmatic province, Texas and New Mexico. Geol. Soc. Am. Bull. 1977, 88, 1428-1436. [CrossRef]

165. Barker, D.S.; Long, L.E.; Hoops, C.K.; Hodges, F.N. Petrology and Rb-Sr isotope geochemistry of intrusions in the Diablo Plateau, northern Trans-Pecos magmatic province, Texas and New Mexico. Geol. Soc. Am. Bull. 1977, 88, 1437-1446. [CrossRef]

166. Henry, C.D.; McDowell, F.W.; Price, J.G.; Smyth, R.C. Compilation of Potassium-Argon Ages of Tertiary Igneous Rocks, Trans Pecos Texas; Geologic Circular 86-2; University of Texas at Austin, Bureau of Economic Geology: Austin, TX, USA, 1986; 34p.

167. McLemore, V.T.; Guilinger, J.R. Geology and Mineral Resources of the Cornudas Mountains, Otero County, New Mexico and Hudspeth County, Texas; Guidebook 44; New Mexico Geological Society: Socorro, NM, USA, 1993; pp. $145-154$.

168. Schreiner, R.A. Mineral Investigation of Wind Mountain and the Chess Draw Area, Cornudas Mountains, Otero County, New Mexico; MLA 26-94; U.S. Bureau of Mines: Washington, DC, USA, 1994; 51p.

169. McLemore, V.T.; Lueth, V.W.; Pease, T.C.; Guilinger, J.R. Petrology and mineral resources of the Wind Mountain laccolith, Cornudas Mountains, New Mexico and Texas. Can. Miner. 1996, 34, 335-347.

170. Nutt, C.J.; O’Neille, J.M.; Kleinkopf, M.D.; Klein, D.P.; Miller, W.R.; Rodriquez, B.D.; McLemore, V.T. Geology and Mineral Resources of the Cornudas Mountains, New Mexico; Open File Report OF97-282; U.S. Geological Survey: Reston, VA, USA, 1997; 46p.

171. New Mexico Bureau of Mines and Mineral Resources; New Mexico State University Southwest Technology Institute; TRC Mariah Associates, Inc. Mineral and Energy Resource Assessment of the McGregor Range (Fort Bliss), Otero County, New Mexico; OF-458; New Mexico Bureau of Mines and Mineral Resources: Socorro, NM, USA, 1998; 543p.

172. McLemore, V.T. Geology and Geochemistry of the Mid-Tertiary Alkaline to Calc-Alkaline Intrusions in the Northern Hueco Mountains and Adjacent Areas, McGregor Range, Southern Otero County, New Mexico; Guidebook 52; New Mexico Geological Society: Socorro, NM, USA, 2002; pp. 129-137.

173. Shannon, W.M. Lithogeochemical Characterization of Intrusive Rocks Comprising the Quitman-Sierra Blanca Igneous Complex, Hudspeth County, Texas. Master's Thesis, University of Texas at El Paso, El Paso, TX, USA, 1986.

174. Shannon, W.M.; Goodell, P.C. Lithogeochemistry of Intrusive Rocks of the Quitman-Sierra Blanca Igneous Complex, Hudspeth County, Texas; Price, J.G., Henry, C.D., Parker, D.F., Barker, D.S., Eds.; In Igneous Geology of Trans-Pecos Texas; Guidebook 23; Texas Bureau of Economic Geology; University of Texas at Austin: Austin, TX, USA, 1986; pp. 225-226.

175. Rubin, J.N.; Price, J.G.; Henry, C.D.; Koppenaal, D.W. Cryolite-bearing and rare metal-enriched rhyolite, Sierra Blanca Peaks, Hudspeth County, Texas. Am. Miner. 1987, 72, 1122-1130.

176. Rubin, J.N.; Price, J.G.; Henry, C.D.; Pinkston, T.L.; Tweedy, S.W.; Koppenaal, D.W.; Peterson, S.B.; Harlan, H.M.; Miller, W.T.; Thompson, R.J.; et al. Mineralogy of Beryllium Deposits Near Sierra Blanca, Texas; InPrecious and Rare Metals Technologies; Torma, A.E., Gundiler, I.H., Eds.; Elsevier: Amsterdam, The Netherlands, 1988; pp. 601-614.

177. Rubin, J.N.; Henry, C.D.; Price, J.G. Hydrothermal zircons and zircon overgrowths, Sierra Blanca Peaks, Texas. Am. Miner. 1989, 74, 865-869.

178. Rubin, J.N.; Price, J.G.; Henry, C.D.; Kyle, J.R. Industrial minerals of the Delaware Basin, Texas and New Mexico. In Geology of the Beryllium-Rare Earth Element Deposits at Sierra Blanca, West Texas; Guidebook 8; Kyle, J.R., Ed.; Society of Economic Geologists: Littleton, CO, USA, 1990; pp. 191-203. 
179. Price, J.G.; Rubin, J.N.; Henry, C.D.; Pinkston, T.L.; Tweedy, S.W.; Koppenaal, D.W. Rare-Metal Enriched Peraluminous Rhyolites in a Continental Arc, Sierra Blanca Area, Trans-Pecos Texas; Chemical Modification by Vapor-Phase Crystallization. In Ore-Bearing Granite Systems; Petrogenesis and Mineralizing Processes; Special Paper 246; Stein, H.J., Hannah, J.L., Eds.; Geological Society of America: Littleton, CO, USA, 1990; pp. 103-120.

180. Standard Silver Corporation, Round Top Beryllium, Uranium, Rare Earth Project: Unpublished Company Report. 2008. Available online: http://www.standardsilvercorp.com/main-sect/uploads/08/round_top_ presentation.pdf (accessed on 3 February 2010).

181. Henry, C.D.; McIntosh, W.; McDowell, F.W.; Lipman, P.W.; Chapin, C.E.; Richardson, M.T. Distribution, timing, and controls of the Mid-Cenozoic ignimbrite flare-up in western North America (abstr.). Geol. Soc. Am. Abstr. Programs 2010, 42, 144.

182. Quintana, A.G. Rare Earth Element Geochemistry of the Sierra Blanca laccoliths, Texas. Master's Thesis, University of Texas at El Paso, El Paso, TX, USA, 2013.

183. Kyger, N. Geology and Geochemistry of the Sierra Blanca Rare Earth Complex, Sierra Blanca, Texas. Master's Thesis, University of Texas at El Paso, El Paso, TX, USA, 2013.

184. Pingitore, N.; Clague, J.; Gorski, D. Round Top Mountain rhyolite (Texas, USA), a massive Y-bearing-fluoritehosted heavy rare earth element (HRRE) deposit. J. Rare Earth. 2014, 32, 90-96. [CrossRef]

185. Hulse, D.E.; Newton, M.C., III. Malhotra, Deepak, Amended NI 43-101 Preliminary Economic Assessment, Round Top Project, Sierra Blanca, Texas, Prepared for Texas Rare Earth Resources: Lakewood, Colo., Gustavson Associates LLC, 28 April 2014. 206p. Available online: http://trer.com/_resources/reports/ Amended_TRER_NI43-101_PEA_FINAL_28April2014.pdf (accessed on 21 January 2018).

186. Elliott, B.A.; O'Neill, L.C.; Kyle, J.R. Mineralogy and crystallization history of a highly differentiated REE-enriched hypabyssal rhyolite: Round Top laccolith, Trans-Pecos, Texas. Miner. Petrol. 2017, 111, 569-592.

187. Levinson, A.A. Beryllium-fluorine mineralization at Aguachile Mountains, Coahuila, Mexico. Am. Miner. 1962, 47, 67-74.

188. McAnulty, W.N.; Sewell, C.R.; Atkinson, D.R.; Raspberry, J.M. Aguachile beryllium-bearing fluorspar district, Coahuila, Mexico. Geol. Soc. Am. Bull. 1963, 74, 735-743. [CrossRef]

189. Simkins, T.H. Geology and Geochemistry of the Aguachile Mountain Fluorspar-Beryllium Mining District, Northern Coahuila, Mexico. Master's Thesis, Sul Ross State University, Alpine, TX, USA, 1983.

190. LeMaitre, R.W. (Ed.) A Classification of Igneous Rocks and Glossary of Terms; Blackwell Scientific Publications: Oxford, UK, 1989; 193p.

191. De la Roche, H.; Leterrier, J.; Grandclaude, P.; Marchal, M. A classification of volcanic and plutonic rocks using R1, R2-diagrams and major element analysis-Its relationships with current nomenclature. Chem. Geol. 1980, 29, 183-210. [CrossRef]

192. Nakamura, N. Determination of $\mathrm{REE}, \mathrm{Ba}, \mathrm{Fe}, \mathrm{Mg}, \mathrm{Na}$, and $\mathrm{K}$ in carbonaceous and ordinary chondrites. Geochim. Cosmochim. Acta 1974, 38, 757-775. [CrossRef]

193. Woolley, A.R.; Kempe, D.R.C. Carbonatites: Nomenclature, average chemical compositions and element distribution. In Carbonatites: Genesis and Evolution; Bell, K., Ed.; Unwin Hyman: London, UK, 1989; pp. 1-14.

194. Gittins, J.; Harmer, R.E. What is a Ferrocarbonatite? A Revised Classification. J. Afr. Earth Sci. 1997, 25, 159-168. [CrossRef]

195. McAnulty, W.N. Fluorspar in New Mexico; Memoir 34; New Mexico Bureau of Mines and Mineral Resources: Socorro, NM, USA, 1978; 64p.

196. Staatz, M.H. Thorium Resources, 1974; Open-File Report 76-690; U.S. Geological Survey: Reston, VA, USA, 1974; 4p.

197. King, W.E.; Harder, V.M. Oil and Gas Potential of the Tularosa Basin-Otero Platform-Salt Basin Graben Area, New Mexico and Texas; Circular 198; New Mexico Bureau of Mines and Mineral Resources: Socorro, NM, USA, $1985 ; 36 \mathrm{p}$.

198. Jowitt, S.M.; Medlin, C.C.; Cas, R.A.F. The rare earth element (REE) mineralisation potential of highly fractionated rhyolites: A potential low-grade, bulk tonnage source of critical metals. Ore Geol. Rev. 2017, 86, 548-562. [CrossRef]

199. McMillan, N.J.; Dickin, A.P.; Haag, D. Evolution of magma source regions in the Rio Grande rift, southern New Mexico. Geol. Soc. Am. 2000, 112, 1582-1593. [CrossRef] 
200. Anthony, E.Y. Source regions of granites and their links to tectonic environment: Examples from the western United States. Lithos 2005, 80, 61-74. [CrossRef]

201. Stein, H.J.; Crock, J.C. Late Cretaceous-Tertiary magmatism in the Colorado mineral belt; rare earth element and samarium-neodymium isotopic studies, in the nature and origin of Cordilleran magmatism. Geol. Soc. Am. Mem. 1990, 174, 195-223.

202. Potter, L.S.; Nordlie, B.; Stormer, J.C. Evolution of the Chico Hills alkalic sill complex, northeast New Mexico: Chemical, mineralogical and isotopic evidence (abstr.). Geol. Soc. Am. Abstr. Programs 1991, $23,57$.

203. Bell, K.; Kjarsgaard, B.A.; Simonett, A. Carbonatites-Into the twenty-first century. J. Petrol. 1999, 39, 1839-1845. [CrossRef]

204. Chapin, C.E. Origin of the Colorado mineral belt. Geosphere 2012, 8, 28-43. [CrossRef]

205. Mitchell, R.H. Carbonatites and carbonatites and carbonatites. Can. Miner. 2005, 43, 2049-2068. [CrossRef]

206. Chakhmouradlan, A.R.; Zaltsev, A.N. Rare earth mineralization in igneous rocks: Sources and processes. Elements 2012, 8, 347-353. [CrossRef]

207. Pilet, S.; Baker, M.B.; Stolper, E.M. Metasomatized lithosphere and the origin of alkaline lavas. Science 2008, 320, 916-919. [CrossRef] [PubMed]

208. Weidendorfer, D.; Schmidt, M.W.; Mattsson, H.B. A common origin of carbonatite magmas. Geology 2017, 45, 507-510. [CrossRef]

209. Sillitoe, R.H. Some metallogenic features of gold and copper deposits related to alkaline rocks and consequences for exploration. Miner. Depos. 2002, 37, 4-13. [CrossRef]

(C) 2018 by the author. Licensee MDPI, Basel, Switzerland. This article is an open access article distributed under the terms and conditions of the Creative Commons Attribution (CC BY) license (http:/ / creativecommons.org/licenses/by/4.0/). 


\title{
On the Extraction of Rare Earth Elements from Geothermal Brines
}

\author{
York R. Smith ${ }^{1, *}$, Pankaj Kumar ${ }^{1}$ and John D. McLennan ${ }^{2,3}$ \\ 1 Metallurgical Engineering Department, University of Utah, Salt Lake City, UT 84115, USA; \\ pankaj.kumar@utah.edu \\ 2 Energy \& Geoscience Institute, University of Utah, Salt Lake City, UT 84108, USA; jmclennan@egi.utah.edu \\ 3 Chemical Engineering Department, University of Utah, Salt Lake City, UT 84112, USA \\ * Correspondence: york.smith@utah.edu; Tel.: +1-801-581-5775
}

Received: 22 July 2017; Accepted: 15 August 2017; Published: 18 August 2017

\begin{abstract}
The availability of rare earth elements from primary resources has come into question in the last two decades. This has sparked various government and industry initiatives to examine potential rare earth element resources apart from virgin ore bodies. Geothermal fluids are potentially significant sources of valuable minerals and metals, while co-recovery with geothermal energy production would be an attractive sustainable system. In this work, we give a brief survey of data collected on rare earth element concentrations in geothermal fluids. A survey of methods and technologies for extracting rare earth elements from geothermal is discussed along with the feasibility of recovering rare earth elements from geothermal brines. Based on the findings of this study, rare earth element extraction from geothermal fluids is technically possible, but neither economically viable nor strategically significant at this time.
\end{abstract}

Keywords: rare earths; geothermal; brine; extraction

\section{Introduction}

Rare earth elements or metals (REE or REM) play a vital role in many current and emerging technologies. Many renewable energy conversion and storage technologies require the use of REE. Alternatives to REE are not likely in the near future, but still remains an area not well investigated. For the time being, the development of widespread sustainable energy systems will depend on the availability and resources of REE and their minerals.

The abundance of most REE in the earth's crust is actually significantly higher than other commonly exploited elements, including platinum group elements and mercury [1]. The supply of any individual REE depends on the geology of its deposit, the costs of the extraction technology employed, and the price of the REEs extracted. However, REE minerals are rarely found in commercially acceptable concentrations [1]. The scarcity of mineral deposits is aggravated by the fact that REEs are never found alone or in equal or predictable distributions. Differential demand for each REE and crustal abundance variations introduce significant challenges to ensuring a stable domestic mineral supply of these elements [2]. As a further obstacle, rare earth milling and processing is a complex, ore-specific operation that has a potential for environmental contamination when not controlled and managed appropriately [2].

Besides mineral ore bodies, REE are often found in geological fluids [3]. Water and steam warmed by the earth's heat are commercially used to generate electricity [4]. This heat is generated within the earth's core and flows outward into cooler rocks, towards the earth's surface. The hot rock heats recirculating meteoric water. Sometimes, this heated water re-emerges as hot springs. Water reaching the surface is not a requirement for a successful geothermal operation. More commonly, heat is conducted or convected from depths where the meteoric water has been heated. This heated water/steam can 
be recovered from moderately shallow (thousands of feet) wells. At the surface, the thermal energy is converted to electric energy if the temperature is high enough; heating and other direct uses are feasible for lower temperature water [5].

Thermal reservoirs that provide water that is hot enough to be used to generate electricity are commonly found at plate boundaries where faults and volcanoes are common, such as the "Ring of Fire" that borders the Pacific Ocean, where oceanic crust of the Pacific plate collides with continental crust. Other areas where volcanic activity is common occur where continental crust is being broken or pulled apart, such as the African Rift Valley or the Basin and Range of the western US. Volcanoes also occur at "hot spots" in places like Yellowstone National Park and Hawaii. These big volcanoes occur despite the fact they are not associated with plate boundaries. Typically, these hot geothermal reservoirs are exploited at depths of 1 to 2 miles below the surface. Larderello, in Italy, was the first geothermal field in the world to be developed. It has been producing electricity commercially since 1913. Other geothermal fields in the United States, New Zealand, and Mexico have been producing electricity for more than 50 years. District heating in Boise, Idaho has operated since 1892 and in Iceland since the 1930 .

There are three main types of geothermal power plants:

- Dry steam plants use steam from geothermal wells to directly spin a turbine, which drives a generator that produces electricity. The Geysers in northern California, the world's largest single source of geothermal power, uses steam technology.

- Flash plants bring hot water to the surface where it boils to produce steam. The hot water (above about $440^{\circ} \mathrm{F}$ ) "flashes" to steam when pressure is reduced in the surface facility. The steam is then sent directly to a turbine to drive the generator. The remaining liquid water is reinjected.

- Binary cycle plants use hot water to boil an organic fluid similar to the fluid used in air conditioners (a working fluid). The water is never directly in contact with the working fluid-heat is exchanged however. The expanding gas produced by boiling this working fluid is used to spin the turbine and drive the generator. All of the water used in the binary plant is injected into the subsurface, where it is naturally reheated and eventually used again.

After heat extraction at the surface, condensed fluids or cooled liquids are typically reinjected into the subsurface reservoir. REEs can exist in the produced geothermal brines. Their speciation depends on temperature, $\mathrm{pH}$, and salinity [6]. Various premium geothermal environments have been evaluated for the occurrence of REE [7-9]. Geothermal fluids interact with the host rocks and consequently become increasingly saturated with various minerals in accordance with the rock composition, fluid chemistry, temperature, pressure and available ligands. Gallup provides a good overview of mineral laden hydrothermal systems (for example, the Salton Sea in California, and oilfield brines associated with salt domes in the United States' Gulf Coast [10]).

Although the concentrations of REE found in geological fluids is far below that of ore grades, extraction of REE from geological fluids presents a potential method to selectively recover REE while avoiding many potential environmental hazards associated with conventional extraction processes, separation and purification (i.e., mining and milling). Due to the mineralogy of REE ores, individual separation of REEs is currently a difficult and costly process. A facile process requiring less reagents and energy with high individual REE selectivity is of high technological interest to REE metallurgy sector. Moreover, extraction of critical commodity materials using inexpensive methods may help to improve the economic viability of geothermal energy plants. The geothermal industry has a unique opportunity to leverage known and unknown extractable materials with attractive revenue streams and reduction in power generation costs. Geothermal power production has started to be successfully integrated with some extraction of marketable byproducts such as silica, lithium, manganese, zinc and sulfur [8].

The process to recover aqueous REE, although much more facile compared to mining, still presents its own technical and environmental challenges. The objective of this work is to give a brief survey of 
REE resources in geothermal fluids and discuss potential methods to recover REE from geothermal fluids and technical viability.

\subsection{Background}

Rare earth elements (REE), as defined by the International Union of Pure and Applied Chemistry (IUPAC), consist of the 15 lanthanide elements (La to Lu), as well as scandium (Sc) and yttrium (Y). Although well known within the scientific community and applied in technologies for some time, REE were rather unknown to the general public till about the late 2000s. Around this time, global availability of REEs appeared to be at substantial risk for a number of reasons. In 2009, 80-90\% of the world's production of REE was from China [11] (which still remains today). With essentially a monopoly on the production of these elements, China changed its position towards the worldwide rare earth market. Introduction of production quotas, export quotas and export taxes, enforced environmental legislation, and granting no new rare earth mining licenses [12,13] caused global market volatility and anxiety among manufacturers of high-tech products containing REE. As a result, there has been increased interest and investigation into non-Chinese REE resources, extraction, separation and purification.

\subsection{Technological Importance}

The commercial significance of REEs is not directly reflected in the volume in which they are used or produced. For example, their annual primary production tonnage is approximately two orders of magnitude less than copper and four orders of magnitude less than iron [14]. However, in 2010, the U.S. Department of Energy released a Critical Materials Strategy report outlining the vital role that REE (and other materials) play in a clean energy economy [15]. This group of elements also plays a vital role in other current technologies such as catalysts, magnets and display technologies.

The U.S. Department of Defense is a large consumer of REE. The military uses REE in precision guidance weaponry, communications, night vision goggles, GPS equipment, batteries, and magnets as well as for metal alloys for armored vehicles and projectiles. In addition, REE are used extensively for communications, photovoltaics, thin-films, medical imaging, and other commercial applications.

The United States led global production of REEs from the 1960s to the 1980s. Since then, processing and manufacturing of the world's supply of REEs - as well as downstream value-added products such as metals, alloys and magnets—-have shifted almost entirely to China [16]. In recent years, there is a renewed focus on advancing the United States' domestic supply of Critical Materials. To comply with the Strategic and Critical Materials Stock Piling Act, every other year, the U.S. Department of Defense reports on stockpile requirements. In 2013, the U.S. Department of Defense studied 76 materials for the National Defense Stockpile (NDS) Requirements Report. Additionally, the five REEs (Dy, Nd, Tb, $\mathrm{Eu}$ and Y) that the U.S. Department of Energy Critical Materials Strategy (2010-2011) deemed to be most critical in the short term for the clean energy economy also appear in the NDS Requirements' Report [17]. For example, magnet and phosphor manufacturers require $\mathrm{Tb}$ and Eu, two of the least abundant REE. These industries will likely be significantly affected in the short term by REE supply issues. Other industries, such as manufacturers of petroleum refining catalysts requiring La and Ce, will be less impacted since those elements are an order of magnitude more abundant [18].

\subsection{Characteristics, Occurrence, Abundance, and Processing}

There are several features in the chemistry of REE, namely lanthanides, which distinguish them from $d$-block metals. Generally, the reactivity of the elements is greater than that of transition metals. A few key features of lanthanides (Ln) are summarized by Cotton [19]:

- Wide range of coordination numbers (generally 6-12, but two, three or four are known).

- Coordination geometries are determined by ligand steric factors rather than crystal field effects.

- They form labile 'ionic' complexes that undergo facile exchange of ligand. 
- The $4 f$ orbits of $\mathrm{Ln}^{3+}$ ions do not participate directly in bonding. Their spectroscopic and magnetic properties are thus largely uninfluenced by the ligand.

- Small crystal field splitting and sharp electronic spectra in comparison with $d$-block metals.

- They prefer anionic ligands with donor atoms of high electronegativity (e.g., $\mathrm{O}, \mathrm{F}$ ).

- They readily form hydrated complexes.

- Insoluble hydroxides precipitate at neutral $\mathrm{pH}$ unless complexing agents are present.

- The chemistry is largely that of one (3+) oxidation state.

- They do not form multiple bonds (e.g., $\mathrm{Ln}=\mathrm{O}$ or $\mathrm{Ln} \equiv \mathrm{N}$ ) of the type known for many transition metals and certain actinides.

- Unlike transition metals, they do not form stable carbonyls and have virtually no chemistry in the 0 oxidation state.

\subsubsection{Occurrences}

In the United States, the major geologic rare earth oxide (REO) occurrences are generally in carbonates and alkaline intrusions, in veins associated with alkaline intrusions, in some iron deposits associated with magmatic-hydrothermal processes, as well as in stream and beach deposits (placers) derived from the erosion of alkaline igneous terranes [20]. Over 100 different REE- bearing minerals are known from REO deposits, 35 of which are outlined in Table 1. The U.S. and world resources are contained primarily in bastnäsite $(\mathrm{Ce}, \mathrm{La})\left(\mathrm{CO}_{3}\right) \mathrm{F}$ and monazite $(\mathrm{Ce}, \mathrm{La}, \mathrm{Nd}, \mathrm{Th})\left(\mathrm{PO}_{4}\right)$. Bastnäsite deposits in China and the United States constitute the largest percentage of the world's rare-earth economic resources, and monazite deposits constitute the second largest segment [21]. A recent work by Weng et al. [22] gives a detailed assessment of REE resources and deposits.

Table 1. A list of some rare earth oxide (REO) minerals. Table modified from Weng et al. [23].

\begin{tabular}{|c|c|c|}
\hline Mineral & Mineral Chemistry & REO wt \% \\
\hline Aeschynite & $(\mathrm{Ce}, \mathrm{Ca}, \mathrm{Fe}, \mathrm{Th})(\mathrm{Ti}, \mathrm{Nb})_{2}(\mathrm{O}, \mathrm{OH})_{6}$ & 36 \\
\hline Allanite (orthite) & $(\mathrm{Ce}, \mathrm{Ca}, \mathrm{Y})_{2}(\mathrm{Al}, \mathrm{Fe}) 3\left(\mathrm{SiO}_{4}\right)_{3}(\mathrm{OH})$ & $3-51$ \\
\hline Ancylite-(Ce) & $\mathrm{SrCe}\left(\mathrm{CO}_{3}\right)_{2}(\mathrm{OH}) \cdot \mathrm{H}_{2} \mathrm{O}$ & $46-53$ \\
\hline Bastnäsite-(Ce) & $(\mathrm{Ce}, \mathrm{La})\left(\mathrm{CO}_{3}\right) \mathrm{F}$ & $70-74$ \\
\hline Britholite-(Ce) & $(\mathrm{Ce}, \mathrm{Ca})_{5}\left(\mathrm{SiO}_{4}, \mathrm{PO}_{4}\right)_{3}(\mathrm{OH}, \mathrm{F})$ & 56 \\
\hline Brockite & $(\mathrm{Ca}, \mathrm{Th}, \mathrm{Ce})\left(\mathrm{PO}_{4}\right) \cdot \mathrm{H}_{2} \mathrm{O}$ & \\
\hline Calcio-ancylite-(Ce) & $(\mathrm{Ca}, \mathrm{Sr}) \mathrm{Ce}_{3}\left(\mathrm{CO}_{3}\right)_{4}(\mathrm{OH})_{3} \cdot \mathrm{H}_{2} \mathrm{O}$ & 60 \\
\hline Cerianite- $(\mathrm{Ce})$ & $\left(\mathrm{Ce}_{4}^{+}, \mathrm{Th}\right) \mathrm{O}_{2}$ & 81 \\
\hline Cerite-(Ce) & $\mathrm{Ce}_{9}{ }^{3+} \mathrm{Fe}^{3+}\left(\mathrm{SiO}_{4}\right)_{6}\left[\mathrm{SiO}_{3}(\mathrm{OH})\right](\mathrm{OH})_{3}$ & 60 \\
\hline Churchite-(Y) & $\mathrm{YPO}_{4} \cdot 2 \mathrm{H}_{2} \mathrm{O}$ & 44 \\
\hline Euxenite-(Y) & $(\mathrm{Y}, \mathrm{Ca}, \mathrm{Ce}, \mathrm{U}, \mathrm{Th})(\mathrm{Nb}, \mathrm{Ta}, \mathrm{Ti})_{2} \mathrm{O}_{6}$ & $<40$ \\
\hline Fergusonite-(Ce) & $(\mathrm{Ce}, \mathrm{La}, \mathrm{Y}) \mathrm{NbO}_{4}$ & 47 \\
\hline Fergusonite- $(\mathrm{Y})$ & $\mathrm{YNbO}_{4}$ & \\
\hline Florencite-(Ce) & $\mathrm{CeAl}_{3}\left(\mathrm{PO}_{4}\right)_{2}(\mathrm{OH})_{6}$ & 32 \\
\hline Fluocerite & $(\mathrm{Ce}, \mathrm{La}) \mathrm{F}_{3}$ & \\
\hline Fluorapatite-(Ce) & $(\mathrm{Ca}, \mathrm{Ce})_{5}\left(\mathrm{PO}_{4}\right)_{3} \mathrm{~F}$ & $0-21$ \\
\hline Gadolinite & $(\mathrm{Ce}, \mathrm{La}, \mathrm{Nd}, \mathrm{Y})_{2} \mathrm{Fe}^{2+} \mathrm{Be}_{2} \mathrm{Si}_{2} \mathrm{O}_{10}$ & 40 \\
\hline Hingganite-(Y) & $\left(\mathrm{Y}, \mathrm{Yb}, \mathrm{Er}_{2}\right)_{2} \mathrm{Be}_{2} \mathrm{Si}_{2} \mathrm{O}_{8}(\mathrm{OH})_{2}$ & \\
\hline Huanghoite-(Ce) & $\mathrm{BaCe}\left(\mathrm{CO}_{3}\right)_{2} \mathrm{~F}$ & 38 \\
\hline Hydroxylbastnäsite-(Ce) & $(\mathrm{Ce}, \mathrm{La})\left(\mathrm{CO}_{3}\right)(\mathrm{OH}, \mathrm{F})$ & 75 \\
\hline Iimoriite- $(\mathrm{Y})$ & $\mathrm{Y}_{2}\left(\mathrm{SiO}_{4}\right)\left(\mathrm{CO}_{3}\right)$ & \\
\hline Kainosite-(Y) & $\mathrm{Ca}_{2}(\mathrm{Y}, \mathrm{Ce})_{2} \mathrm{Si}_{4} \mathrm{O}_{12}\left(\mathrm{CO}_{3}\right) \cdot \mathrm{H}_{2} \mathrm{O}$ & 38 \\
\hline Loparite-(Ce) & $(\mathrm{Ce}, \mathrm{Na}, \mathrm{Ca})(\mathrm{Ti}, \mathrm{Nb}) \mathrm{O}_{3}$ & $32-34$ \\
\hline Monazite-(Ce) & $(\mathrm{Ce}, \mathrm{La}, \mathrm{Nd}, \mathrm{Th}) \mathrm{PO}_{4}$ & $35-71$ \\
\hline Mosandrite & $(\mathrm{Na}, \mathrm{Ca}, \mathrm{Ce})_{3} \mathrm{Ti}\left(\mathrm{SiO}_{4}\right)_{2} \mathrm{~F}$ & $<65$ \\
\hline Parisite-(Ce) & $\mathrm{Ca}(\mathrm{Ce}, \mathrm{La})_{2}\left(\mathrm{CO}_{3}\right)_{3} \mathrm{~F}_{2}$ & 59 \\
\hline Rhabdophane & $(\mathrm{Ce}, \mathrm{La}) \mathrm{PO}_{4} \cdot \mathrm{H}_{2} \mathrm{O}$ & \\
\hline Samarskite-(Y) & $\left(\mathrm{Y}, \mathrm{Ce}, \mathrm{U}, \mathrm{Fe}^{3+}\right)_{3}(\mathrm{Nb}, \mathrm{Ta}, \mathrm{Ti})_{5} \mathrm{O}_{16}$ & 12 \\
\hline Synchysite-(Ce) & $\mathrm{Ca}(\mathrm{Ce}, \mathrm{La})\left(\mathrm{CO}_{3}\right)_{2} \mathrm{~F}$ & $49-52$ \\
\hline Thalénite-(Y) & $\mathrm{Y}_{3} \mathrm{Si}_{3} \mathrm{O}_{10}(\mathrm{OH})$ & 63 \\
\hline Uraninite & $(\mathrm{U}, \mathrm{Th}, \mathrm{Ce}) \mathrm{O}_{2}$ & \\
\hline Vitusite-(Ce) & $\mathrm{Na}_{3}(\mathrm{Ce}, \mathrm{La}, \mathrm{Nd})\left(\mathrm{PO}_{4}\right)_{2}$ & \\
\hline Xenotime- $(\mathrm{Y})$ & $\mathrm{YPO}_{4}$ & $52-67$ \\
\hline Yttrofluorite & $(\mathrm{Ca}, \mathrm{Y}) \mathrm{F}_{2}$ & \\
\hline Yttrotantalite-(Y) & $\left(\mathrm{Y}, \mathrm{U}, \mathrm{Fe}^{2+}\right)(\mathrm{Ta}, \mathrm{Nb}) \mathrm{O}_{4}$ & $<24$ \\
\hline
\end{tabular}


From a geologic perspective, it is no surprise that geothermal fluids can contain measureable quantities of REEs. Geochemists recognize the utility of REEs as powerful tools for tracing geochemical processes within the earth [3]. Numerous studies over the years have reported on the occurrence of REE species in groundwater flow systems. Recently, the work of Neupane and Wendt [24] give a comprehensive collection of geothermal minerals, which will be discussed in more detail in a section to follow. REE also occur in trace amounts in seawater. Elderfield and Greaves [25] report on the distribution of REE in the oceanic water column. The REEs were reported in trace amounts, on the order of $1 \sim 10 \times 10^{-12} \mathrm{~mol} / \mathrm{kg}$.

\subsubsection{Abundance}

Haque et al. [26] report on the crustal abundance, resource tonnage, and years of reserves' estimates. Crustal abundances for REE are in the range of $0.48-68 \mathrm{ppm}$, and resource timeframes of 600 to 57,000 years of supply (Table 2). The resources have been calculated using data on the percentage of rare earths found in various ore deposits and the known resources of rare earth containing ores [27]. According to the 2017 U.S. Geological Survey, the world resources of rare earth oxides is reported as $120 \mathrm{Mt}[21]$.

Table 2. Summary of rare earth element (REE) crustal abundance, resource tonnage, and years of reserves estimates. Date sources $[2,26]$.

\begin{tabular}{ccccc}
\hline Element & Crustal Abundance $(\mathbf{p p m})$ & Resource Tons & Production Tons/Annum & Years of Reserves \\
\hline $\mathrm{La}$ & 32 & $22,600,000$ & 12,500 & 1800 \\
$\mathrm{Ce}$ & 68 & $317,000,000$ & 24,000 & 1300 \\
$\mathrm{Pr}$ & 9.5 & $4,800,000$ & 2400 & 2000 \\
$\mathrm{Nd}$ & 38 & $16,700,000$ & 7300 & 2300 \\
$\mathrm{Pm}$ & $\mathrm{NA}$ & $\mathrm{NA}$ & $\mathrm{NA}$ \\
$\mathrm{Sm}$ & $\mathrm{NA}$ & $2,900,000$ & 700 & 4100 \\
$\mathrm{Eu}$ & 7.9 & 244,333 & 400 & 610 \\
$\mathrm{Gd}$ & 2.1 & $3,622,143$ & 400 & 9100 \\
$\mathrm{~Tb}$ & 7.7 & 566,104 & 10 & 57,000 \\
$\mathrm{Dy}$ & 1.1 & $2,980,000$ & 100 & 29,800 \\
$\mathrm{Ho}$ & 6 & $\mathrm{NA}$ & 10 & $\mathrm{NA}$ \\
$\mathrm{Er}$ & 1.4 & $1,850,000$ & 500 & 3700 \\
$\mathrm{Tm}$ & 3.8 & 334,255 & 50 & 6700 \\
$\mathrm{Yb}$ & 0.48 & $1,900,000$ & 50 & 38,000 \\
$\mathrm{Lu}$ & 3.3 & 395,000 & $\mathrm{NA}$ & $\mathrm{NA}$ \\
$\mathrm{Y}$ & 0.4 & $9,000,000$ & 8900 & 1011 \\
$\mathrm{Sc}$ & 30 & $\mathrm{NA}$ & $\mathrm{NA}$ & $\mathrm{NA}$ \\
\hline
\end{tabular}

The authors note that although this assessment is a simplification, since the life of a particular resources will be influenced by discovery of new deposits, technological efficiency such as use of less specific material per product, extraction efficiency of low grade ore, and finally potentially the stream of recovered metal from recycling [26]. A survey on the recycling of REEs is given by Anderson et al. [28].

\subsubsection{Processing}

Figure 1 shows an abridged diagram of the conventional process route of REE ores to REE metal. The primary steps involved are as follows:

1. Mineral mining and comminution;

2. Physical beneficiation, chemical separation, and concentration from the host material in acidic or alkaline solutions;

3. Separation and purification using solvent extraction or ion exchange, and;

4. Reduction of the individual REOs into pure metals [1].

The first step typically includes crushing the ore and separating the REE-bearing minerals by magnetic, flotation, or gravimetric separation. Since this separation process dramatically increases the 
percentage of REOs, typically from a few weight percent to over $50 \mathrm{wt} \%$ a large amount of waste rock (tailings) is generated and typically must be managed onsite.

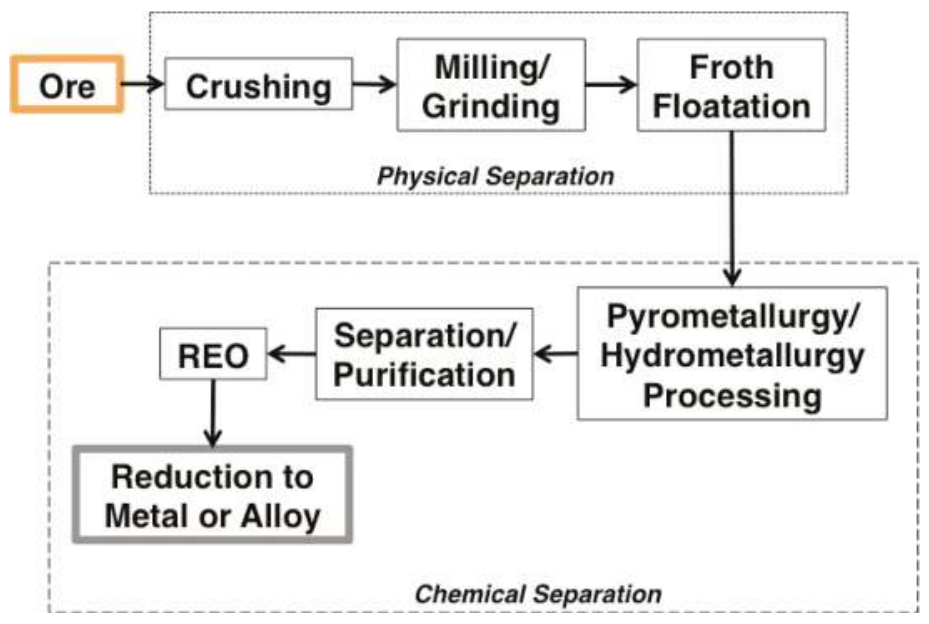

Figure 1. A generalized process flow diagram of rare earth element (REE) processing from ore to final products.

Subsequent steps in the process aim to change the concentrated mineral into more valuable chemical forms with thermal and/or chemical treatments. These typically involve hydrometallurgy (e.g., leaching, extraction, precipitation) or pyrometallurgical techniques (e.g., thermochemical reduction). A fundamental review on REE floatation is given by Anderson et al. [29], while a primer on hydrometallurgical separation of REEs is given by Kronholm et al. [30]. A critical review on solvent extraction of REEs from aqueous solution is given by [31]. Faris et al. reviews the application of ferrous pyrometallurgy for the beneficiation of REE ores [32].

After mineral beneficiation, the most common method of separating REEs is to use ion-exchange resins or solvent extraction methods using tributyl phosphate (TBP) and di-(2-ethylhexyl) phosphoric acid (D2EHPA). Ionic liquids $[33,34]$ have also been investigated for REE separation. After which, the REEs are then often recovered as chlorides, fluorides, or hydroxides. These are then often converted to REOs. The REOs can then be reduced to individual REE metals or an alloy.

It should be noted that the actual REO processing is rather complex and difficulty arises in separation of individual REEs requiring several processing steps. For a more detailed overview of REE extraction and recovery, there are several texts available in the literature (for example, see [35-37]).

\subsection{Environmental Issues in REE Mining and Processing}

The process to recover REEs from geothermal fluids could circumvent some of the significant commercial challenges of conventional rare earth milling and processing. As mentioned, these are complex, ore-specific operations that have the potential for environmental contamination when not controlled and managed appropriately [2]. Weng et al. [23] survey and discuss the environmental impacts of extraction from various types of REE deposits. As noted by Weng et al. [23], there are few published detailed studies on the actual impacts of REE processing. Ali [38] comments on the societal and environmental impacts of the REE industry, suggesting the necessity for a more circular supply chain to lessen such impacts.

Recently, Tharumarajah and Koltun [39] performed Life Cycle Assessment (LCA) on Bayan Obo deposit in China to determine the equivalent greenhouse gas (GHG) emissions for production for 
REOs. Their analysis shows that the production of $\mathrm{Sm}, \mathrm{Eu}$ and $\mathrm{Gd}$ oxides emits around $55 \mathrm{~kg}$ of $\mathrm{CO}_{2}$ equivalent per $\mathrm{kg}$ of oxide produced. These GHG emission values are significantly higher than for $\mathrm{Fe}$ and $\mathrm{Cu}$, for example. Norgate and Haque [40] determined the global warming potential for Fe to be $11.9 \mathrm{~kg}$ of $\mathrm{CO}_{2}$ equivalent emissions per ton of Fe production, or $\mathrm{kg} \mathrm{CO}_{2}-\mathrm{e} / \mathrm{t}$, bauxite to be $4.9 \mathrm{~kg} \mathrm{CO}-\mathrm{e} / \mathrm{t}$ bauxite, and $\mathrm{Cu}$ concentrate to be $628.2 \mathrm{~kg} \mathrm{CO}_{2}-\mathrm{e} / \mathrm{t} \mathrm{Cu}$ concentrate. For $\mathrm{Cu}$ metal, Northey et al. [41] determined $2.6 \mathrm{~kg}$ of $\mathrm{CO}_{2}$ emitted per $\mathrm{kg}$ of produced $\mathrm{Cu}$ metal. A follow-up publication by Koltun and Tharumarajah [42] extended their LCA analysis for REEs produced from the Bayan Obo deposit. In summary, GHG emissions for Light REOs (La-, Ce-, Pr-oxide) to be $32.29 \mathrm{~kg}$ $\mathrm{CO}_{2}$-e/kg REO, Medium REOs (Nd-, Pm-, Sm-oxide) to be $30.29 \mathrm{~kg} \mathrm{CO}_{2}$-e $/ \mathrm{kg} \mathrm{REO}$, and Heavy REOs (Gd-Lu, Sc-, and Y-oxide) to be $34.49 \mathrm{~kg} \mathrm{CO}$-e/ $\mathrm{kg}$ REO. The oxides, $\mathrm{Eu}_{2} \mathrm{O}_{3}, \mathrm{Dy}_{2} \mathrm{O}_{3}, \mathrm{~Tb}_{4} \mathrm{O}_{7}$ and $\mathrm{Sc}_{2} \mathrm{O}_{3}$ have substantially higher GHG emissions when compared to the other REOs. This is a result of a lower extractable mass when reducing these oxides to metals [42]. For all REE processing, REO separation has the highest contribution to GHG emissions when compared to mining and beneficiation, and reduction.

Radionuclides are often associated with REE mineral deposits including $U$ and Th. Mining and processing of radioactive materials necessitates active and comprehensive monitoring of radiation levels and proper protocols for material handling, processing, and disposal. Table 3 gives a summary of potential environmental impacts in REE mining, processing, and recycling.

Table 3. Summary of potential environmental impacts in REE mining, processing, and recycling. Table adapted from [43].

\begin{tabular}{|c|c|c|}
\hline Activity & Emission Source(s) & Primary Pollutants of Concern \\
\hline \multirow{4}{*}{ Mining } & Overburden & Radiological contaminates \\
\hline & Waste rock & Metals \\
\hline & Sub-ore stockpile & Mine influenced waters (e.g., acid/alkaline drainage) \\
\hline & Ore stockpile & Dust and associated pollutants (e.g., PM 2.5) \\
\hline \multirow{6}{*}{ Processing } & Crushing/Grinding & Dust \\
\hline & Tailings & Radiological contaminates \\
\hline & Tailings impoundment & Metals \\
\hline & Separation and Purification & Turbidity \\
\hline & Liquid waste & Organics \\
\hline & & Dust and associated pollutants \\
\hline \multirow{9}{*}{ Recycling } & Collection & Transportation pollutants \\
\hline & Dismantling and separation & Dust and associated pollutants \\
\hline & Scrap waste & Volatile Organic Compounds \\
\hline & Landfill & Metals \\
\hline & Processing & Dust and associated pollutants \\
\hline & & Volatile Organic Compounds \\
\hline & & Dioxins \\
\hline & & Metals \\
\hline & & Organics \\
\hline
\end{tabular}

\section{REEs in Geothermal Brines}

Neupane and Wendt [24] present a recent and comprehensive study on the mineral contents of geothermal brines in the U.S. Data from 8000 entries was compiled and summarized in their study. In regard to REEs, a separate database was also prepared from journal articles published by Wood et al. [44-48] and ongoing Idaho National Laboratory (INL) projects analyzing geothermal/oil and gas well brines of the eastern Snake River Plain, southeastern Idaho, and Wyoming Basin. Figure 2 shows a representation of the data compiled by Neupane and Wendt [24] of total filtered REE concentration (ng $/ \mathrm{kg}$, or parts per trillion) versus well $\mathrm{pH}$. Not all of the data from Neupane and Wendt's study [24] was extracted.

We can see that the majority of the samples collected contain sub-ppb levels of REEs and the fluids are alkaline in nature. For REEs levels above the ppb range, the fluids typically have an acidic $\mathrm{pH}$. REE adsorption is generally favored at near neutral or slightly basic $\mathrm{pH}$. It should to be noted that 
unfiltered samples often contain much higher concentration of RE than filtered samples. Of the REEs present in geothermal fluids, the most abundant REEs typically are La, Ce and Nd.

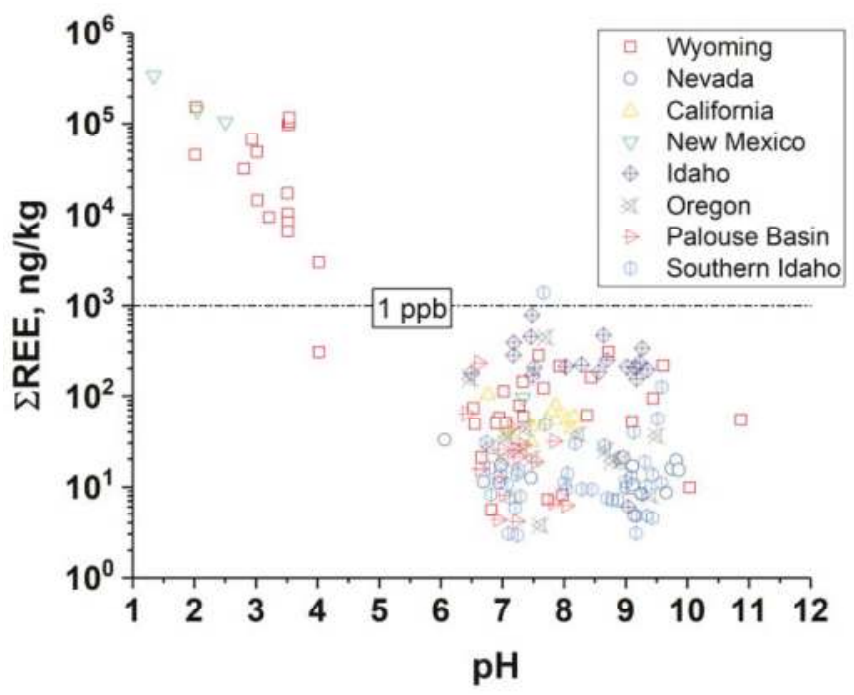

Figure 2. Filtered brine concentration of total REEs in solution plotted versus brine $\mathrm{pH}$. The figure is a representation of the data complied from Neupane and Wendt [24] and not all data was extracted.

\section{Potential Methods of REE Extraction from Geothermal Brines}

Extracting REE at such a low concentration from geothermal brines is challenging. Unknown mineral abundance and cost effective technology for separation from geothermal brine present addition challenges. Recently, significant efforts are being made to develop technologies to extract REE from geothermal brine, since the geothermal brine can be a cost-effective mineral resource [25]. Several technologies have been developed and suggested for the extraction of REEs using geothermal brine as a resource. However, the suggested techniques are still in lab-scale studies, and significant work is required before these are used in real applications. Some of the suggested techniques that can be used to recover REEs from the geothermal brine are discussed.

All of the methods discussed here are fundamentally separation processes. Metrics for the effectiveness of the separation is often measured by the selectivity, energy and water use, and waste production. For viable separation, the total operating cost cannot be greater than the value of recovered REEs. Environmental costs should be accounted for ideally; however, many are hard to quantify monetarily.

\subsection{Adsorption}

Adsorption can be used to recover metal ions from low-concentration sources by means of relatively simple processes. Recovering REEs using adsorbents involves a combination of solid-phase sorbents, water treatment, and established mineral processing unit operations. This approach offers advantages such as environmental friendliness, scalability, and high processing speed. Research to date showed that the new sorbent materials can be integrated into relevant mineral recovery structures such as packed beds, fluidized beds, various filter structures, and various thin membranes. A variety of sorbents show high affinities towards a variety of REEs with good capacities, rapid kinetics, and economics. Although many REE adsorbents have been studied [49-61], to date, there is no adsorbent material in practical use. 
Metal oxide adsorbents such as the oxides of Fe and Mn [62] have been predominantly examined for REE adsorption. Functionalized magnetic nanoparticles, for example [63], have gained considerable interest due to simple recovery of the adsorbent material via magnetic field. In particular, a project at Pacific Northwest National Laboratory (PNNL, Richland, WA) [64,65] examined composite nanoparticles having a core structure of magnetic iron oxide and an active shell structure made of silica or metal organic framework (MOF) sorbent functionalized using chelating ligands selective to REEs. Their process introduces these nanoparticles at a low concentration (about $0.05 \mathrm{wt} \%$ ) into the concentrated geothermal fluid (using plant heat exchanger). The process is designed for a short interaction of concentrated brine with the functionalized nanoparticles to bind REEs on surface of the particles. Separating out the nanoparticles with an electromagnet followed by standard extraction techniques extracts the REEs. The study at PNNL identified the two MOF (i)-SO3-(ii) diethylene triamine (DETA) that can be used to selectively adsorb REE. These MOFs were shown to effectively stripped five REEs in simulated brine solution when the nanoparticles were exposed for $5 \mathrm{~min}$. A 20\% rate of return was showed in the experimental study for REE extraction at PNNL. Functionalized carbons have also been examined for REE extraction. Recently, we have demonstrated the application of recycled tires as an adsorbent for the extraction of aqueous REEs such as Y, La, Ce, Sm and Nd [66].

\subsection{Ion-Exchange}

Ion exchange (IX) is a highly effective separation technique mainly for dilute solutions. Development of synthetic resins in the 1940s marked a significant advance in development of commercial IX processes. Separation of REE into their individual components as part of the Manhattan Project in World War II was a notable achievement of IX [67]. Subsequent development of chelating resins was a significant advancement in applications of IX to metallurgical separations [68]. The use of IX resins and chelation IX resins is common in commercial systems to selectively separate metal ions. Some advantages of IX process includes a simple design, applicable to dilute feeds, has the ability to achieve a high concentration factor, and has virtually no loss of separation media to the environment. The downside to IX is that the method does not work well with concentrated feeds, the kinetics are usually slow, and depending on the separation agent used selectivity can be limited. For IX, selectivity is based on the metal ion charge, while for chelation IX, high selectivity is achieved with ligands [68]. Selective adsorbents may improve the economics of extraction over IX resins. Generally adsorbents can tolerate a wider domain of operating conditions, whereas IX requires more pretreatment.

\subsection{Solvent Extraction (SX)}

Solvent extraction involves transfer of a solute from one liquid phase to another immiscible or partially immiscible liquid that is in contact with the first phase [68]. The first phase (aqueous) contains the metal to be concentrated into the second phase. The second phase consists of an organic liquid containing an active extractant and appropriate modifiers dissolved in a solvent (diluent). The leach solution and the organic liquid form immiscible phases and must have low mutual solubilities. Upon contact, the dissolved metal or metal complex ions and the extractant molecules undergo chemical exchange reactions [69]. The metal ions are then recovered through a stripping process of the organic phase. In the metal industry, $\mathrm{SX}$ is extensively used in recovery of $\mathrm{Cu}$ from ore leach solutions, amounting to approximately a quarter of global Cu production [67]. Limitations of SX arise from the use of organic volatile, combustible, and toxic solvents. Often, traces of solvent components are carried into effluent streams, which necessitate environmental abatement. A review on SX for REEs is given by Xie at al. [31].

\subsection{MRT-Molecular Recognition Technology}

This process, termed molecular recognition technology (MRT), is effective at various stages in metal life cycles [70,71]. The MRT process is based on selective recognition of specific metal ion guests 
by supported ligand hosts allowing highly selective individual separation and recovery of metals from complex matrices present in industrial feed solutions.

An early application of molecular recognition to selective host-guest interactions was the pioneering work of Pedersen, for which he shared the Nobel Prize in 1987 [72]. Pedersen synthesized a large number of cyclic polyethers [73] and observed that certain number of these had remarkable selectivity for specific alkali metal ions. This selective host-guest interaction was quantitated and its range expanded to other macrocycles by Izatt et al. [74,75] and others [76]. Early work by Izatt and coworkers with selective transport of metal ions in supported liquid membrane systems [77] led to the development of solid supported SuperLig ${ }^{\circledR}$ systems (IBC Advanced Technologies, American Fork, UT, USA) in which the metal-selective ligand was attached by a tether to a solid support, such as silica gel [78]. This achievement made large scale, selective metal separations possible [79]. After passing several volumes of brine, the species of interest can be stripped and concentrated using aqueous ethylenediaminetetraacetic acid/ $\mathrm{HCl}$ solution. The MRT procedure is described [79] and examples are given of its commercial use, environmental, procedural, economic, metal conservation, and metal resource preservation benefits associated with the use of green chemistry principles are discussed.

\subsection{Extraction Using Engineered Microbes}

Metals leaching using microbes is an established technique for metals extraction from liquid media [80]. The approach is based on the fact that some microorganisms such as bacteria bind with metal ions. An early study made an assessment for metal binding capacities of bacteria based on a dry weight basis, and estimated that binding capacity of bacteria is quite comparable to the binding capacities of commercial ion exchangers $\left(10^{-5}\right.$ to $\left.10^{-3} \mathrm{~mol} \mathrm{metal} / \mathrm{g}\right)$ [81]. In various studies, several mesophilic bacteria have been engineered to show the metal-binding motifs on their cell surface with increased binding capacity and selectivity [82-86]. For example, binding of $\mathrm{Gd}^{3+}$ with the bacteria has been demonstrated [87]. Following that, a selective bioleaching technique is recently proposed to recover REE metals from geothermal fluid based on the lab scale experiment [88]. In the study, Geobacillus stearothermophilus was used as a biosorbent and SbsB protein as a surface layer (S-layer) scaffold to recover the Gd in geothermal fluid. In the approach, the S-layer modification by mesophile Escherichia coli was suggested. With the engineered S-layer, the binding efficiency of $\mathrm{Gd}^{3+}$ ions was increased up to $80 \%$ in $\mathrm{nM}$ concentration of $\mathrm{Gd}$ in geothermal brine. A review on the biosorption and bioaccumulation of valuable metals from geothermal brine is presented by Lo et al. [89]. These data demonstrate that the bioleaching can be a possible technique to recover REEs from the geothermal fluid present in trace levels; however, to establish this as a viable technique, a significant amount of research is required. Although such an approach may have a low capital cost, the kinetics may be lagging.

\subsection{Magnetic Segregation}

O'Brian [90] describes in a patent a magnetic segregation method that can be used to recover REEs from the geothermal fluids. The method involves collection of the hot geothermal brine in a heat exchanger followed by cooling the hot fluid down. As the fluid cools down, REEs in the brine condense out of the fluid, forming a condensate. The condensate is then accelerated by applying a physical force (gravity or centrifuge), followed by applying a magnetic force simultaneously. Due to combinations of both physical and magnetic forces, the components of condensate segregate differently. The segregated REEs can be collected and removed from the condensate. The process can be optimized by varying the duration, intensity, time and constancy of the two forces to for the segregation of the REEs from other components of the condensates.

\section{Discussion}

The possibility of extracting minerals from the geothermal brines has been a great interest to the geothermal communities including private sector and various government agencies [91-94]. 
Numerous studies, ranging from the brine characterization to operation at pilot level to extract minerals from the geothermal brines have been reported [94-96]. Over the years, several technologies to extract minerals such as precious minerals ( $\mathrm{Ag}, \mathrm{Au}, \mathrm{Pd}, \mathrm{Pt}, \mathrm{Cs}$ and $\mathrm{Sr}$ ), $\mathrm{Cu}, \mathrm{Sn}, \mathrm{Li}, \mathrm{Mg}$, from geothermal brine are developed. The precious metals (PMs) extraction from the geothermal brine has gained considerable interest. PMs are present in the geothermal brines in the $0.1-10 \mathrm{ppb}$ range, whereas the concentrations of PMs in scale are found to be higher, in the 100-1000 s of ppb range. Since the price of the PMs is orders of magnitude greater than that of REEs (i.e., 10,000 \$/ kg for PMs vs. 1-100 $\$ / \mathrm{kg}$ for REOs), economic benefits have long been identified. The well-established extraction technologies to extract some of the PMs from geothermal brine and scale are summarized in Table 4.

Table 4. Extraction technologies for precious metals (PMs) from geothermal brines.

\begin{tabular}{ccc}
\hline Minerals & Extraction Technology & Reference \\
\hline \multirow{2}{*}{$\mathrm{Ag}$} & Sulphidization & {$[97]$} \\
& Precipitation by metallic iron & {$[93]$} \\
& Deposition in steel vessel & {$[98]$} \\
\hline \multirow{3}{*}{$\mathrm{Au}$} & Scale deposition & {$[99]$} \\
& Deposition in extraction vessel & {$[98]$} \\
$\mathrm{Pt}$ & Bioleaching & {$[100]$} \\
$\mathrm{Sr}$ & Carbon interaction with brine & {$[100]$} \\
& Evaporative extraction & {$[101]$} \\
\hline
\end{tabular}

The extraction of PMs from geothermal brine has been demonstrated to have economical benefit using essentially the same technologies/methods as that would be used for REE extraction. However, extraction of REEs is not viable due to economic constrains and a much higher volume of demand. To compare, the U.S. consumption of all REE metals and compounds was estimated to be $17,000 \mathrm{t}$ of REO in 2014 [102]. In the same year for $\mathrm{Au}$, the U.S. produced around $200 \mathrm{t}$ and consumption was reported to be $150 \mathrm{t}$ [103]. If we average all of the data points (total of 160 data points) in Figure 2, for a rough estimation of total REEs in the resources, the REE concentration is around $0.17 \mathrm{ppm}$. In contrast, REO ore grades in conventional mining are typically $0.05-0.5 \%$ or $500-5000 \mathrm{ppm}$.

Due to the low concentration and low price, economic extraction of REE from geothermal brine alone does not appear to be viable. If we assume a typical geothermal power plant operates at a flow rate of $20 \mathrm{~kg} / \mathrm{s}$ of brine for $1 \mathrm{MW}_{\mathrm{e}}$ power $\left(200{ }^{\circ} \mathrm{C}\right.$ reservoir) [104], a typical $20 \mathrm{MW}$ facility passes around $1.26 \times 10^{10} \mathrm{~kg}$ /year of brine through its facility. If we assume the brine to have a REE content of approximately $100 \mathrm{ppb}$ REEs, this comes to around $1261 \mathrm{~kg}$ of extractable REEs. Now, if we assume the distribution of REEs in the brine to have a similar REE distribution as that of Mountain Pass ore (49.6\% Ce, $32.4 \% \mathrm{La}, 12.37 \% \mathrm{Nd}$, assume balance with gangue) and a $90 \%$ recovery, $358 \mathrm{~kg} \mathrm{of} \mathrm{La}_{2} \mathrm{O}_{3}$, $563 \mathrm{~kg}$ of $\mathrm{CeO}_{2}$, and $140 \mathrm{~kg}$ of $\mathrm{Nd}_{2} \mathrm{O}_{3}$ for a total of around $1071 \mathrm{~kg}$ REEs recovered per year could be expected. If we assume market prices (buying) of 2, 2 and $42 \$ / \mathrm{kg}$ for $\mathrm{CeO}_{2}, \mathrm{La}_{2} \mathrm{O}_{3}$ and $\mathrm{Nd}_{2} \mathrm{O}_{3}$, respectively, only around $\$ 7700$ worth of REEs can be viably collected. Note that this does not take into account processing costs of the REEs. This one processing plant would contribute to approximately $0.006 \%$ of REE domestic demand.

Geothermal energy production cost is around $0.04-0.10 \$ / \mathrm{kWh}$, with capital cost estimates of around $2500 \$ / \mathrm{kW}$ installed. If we again assume the base case of a $20 \mathrm{MW}$ facility, the capital cost of the power plant is approximately $\$ 50,000,000$ with an annual operating cost of $\$ 7,000,000$ at $0.04 \$ / \mathrm{kWh}$. If REE extraction will help reduce operating costs by an additional revenue stream, the selling of REOs would contribute to $0.11 \%$ or less of the operating budget. To be noted, the revenue calculated for REOs does not account for any processing costs of the REOs. Given this crude analysis with several assumptions, REE extraction from geothermal brine only seems feasible if extracted with other co-products. Neupane and Wendt [24] concluded in their study that certain value can be extracted 
from geothermal brines, namely from silica and lithium. Given today's market value and technology, silica and lithium are currently the only economical extractable minerals.

\section{Conclusions}

This work has made an attempt to briefly summarize studies on REEs in geothermal fluids and technologies for the extraction thereof. Recovering REEs from geothermal fluids presents many advantages, but these are not met with out technical challenges and economical constraints. The following conclusions can be drawn from this study:

- REEs are present in measureable quantities in geothermal fluids using modern analytical techniques

- A number of technologies exist for extraction of REEs from geothermal fluids

- Due to the low concentration of REEs in the fluid, REEs recovered from geothermal fluids does not present itself as a resource able to meet current domestic demand

- Economic constraints hinders the viability for REE extraction alone

- Co-recovery with other valuable metals and minerals will improve the overall economic feasibility.

Acknowledgments: This work was supported in part by the Dawn and Roger Crus Renewable Energy Center, College of Mines and Earth Sciences, University of Utah, Salt Lake City, UT, USA. The authors would like to thank Pamela Bogust for assistance in preparing this work.

Author Contributions: Y.R.S. developed the concept. P.K. and Y.R.S. wrote on technologies for extraction, and J.D.M wrote on mineral resources and geothermal energy. Y.R.S. and J.D.M discussed and analyzed the data. Y.R.S. wrote the remaining sections of the manuscript. All authors reviewed a final version.

Conflicts of Interest: The authors declare no conflict of interest.

\section{References}

1. Gupta, C.; Krishnamurthy, N. Extractive metallurgy of rare earths. Int. Mater. Rev. 1992, 37, 197-248. [CrossRef]

2. Reisman, D.J.; Weber, R.J. Rare Earth Elements: A Review of Production, Processing, Recycling, and Associated Environmental Issues; U.S. Environmental Protection Agency: Cincinnati, OH, USA, 2012.

3. Johannesson, K.H. Rare Earth Elements in Groundwater Flow Systems; Springer Science \& Business Media: Dordrecht, The Netherlands, 2006.

4. DiPippo, R. Geothermal Power Generation: Developments and Innovation; Woodhead Publishing: Cambridge, UK, 2016.

5. Moore, J.N.; Simmons, S.F. More power from below. Science 2013, 340, 933-934. [CrossRef] [PubMed]

6. Lewis, A.J.; Komninou, A.; Yardly, B.W.D.; Palmer, M.R. Rare earth element speciation in geothermal fluids from Yellowstone National Park, Wyoming, USA. Geochim. Cosmochim. Acta 1988, 62, 657-663. [CrossRef]

7. Fowler, A.P.; Zierenberg, R.A. Rare earth element concentrations in geothermal fluids and epidote from the Reykjanes geothermal system, Iceland. In Proceedings of the World Geothermal Congress 2015, Melbourne, Australia, 19-25 April 2015.

8. Bakane, P. Overview of extraction of minerals/metals with the help of geothermal fluid. In Proceedings of the 38th Workshop on Geothermal Reservoir Engineering Stanford University, Stanford, CA, USA, 11-13 February 2013.

9. Segneri, B.; Deprizio, J.; Reinhardt, T. Geologic provenance of rare earth elements in the united states, and their potential collocation with geothermal resources. In Proceedings of the Thirty-Ninth Workshop on Geothermal Reservoir Engineering Stanford University, Stanford, CA, USA, 24-26 February 2014.

10. Gallup, D.L. Geochemistry of geothermal fluids and well scales, and potential for mineral recovery. Ore Geol. Rev. 1998, 12, 225-236. [CrossRef]

11. Jacoby, M.; Jiang, J. Securing the supply of rare earths. Chem. Eng. News 2010, 88, 9-12. [CrossRef]

12. Gschneidner, K.A., Jr. The rare earth crisis-The supply/demand situation for 2010-2015. Mater. Matters 2011, 6, 32-37.

13. Voncken, J.H.L. The Rare Earth Elements: An Introduction; Springer: Berlin/Heidelberg, Germany, 2015.

14. USGS. National Minerals Information Center. Available online: http://minerals.usgs.gov/minerals/ (accessed on 5 October 2014). 
15. Bauer, D.; Diamond, D.; Li, J.; Sandalow, D.; Telleen, P.; Wanner, B. 2010 Critical Materials Strategy; U.S. Department of Energy: Washington, DC, USA, 2010.

16. Grasso, V.B. Rare Earth Elements in National Defense: Background, Oversight Issues, and Options for Congress; U.S. Environmental Protection Agency: Cincinnati, OH, USA, 2013.

17. Office of the Under Secretary of Defense for Acquisition, Technology and Logistics. Strategic and Critical Materials 2013 Report on Stockpile Requirements; U.S. Department of Defense: Arlington, VA, USA, 2013.

18. Jordens, A.; Cheng, Y.P.; Waters, K.E. A review of the beneficiation of rare earth element bearing minerals. Miner. Eng. 2013, 41, 97-114. [CrossRef]

19. Cotton, S. Lanthanide and Actinide Chemistry; John Wiley \& Sons: Hoboken, NJ, USA, 2013.

20. Long, K.R.; Van Gosen, B.S.; Foley, N.K.; Cordier, D. The Principal Rare Earth Elements Deposits of the United States: A Summary of Domestic Deposits and A Global Perspective; Springer: Berlin/Heidelberg, Germany, 2012.

21. Ober, J.A. Mineral Commodity Summaries 2017; U.S. Geological Survey: Reston, VA, USA, 2017.

22. Weng, Z.; Jowitt, S.M.; Mudd, G.M.; Haque, N. A detailed assessment of global rare earth element resources: Opportunities and challenges. Econ. Geol. 2015, 110, 1925-1952. [CrossRef]

23. Weng, Z.; Jowitt, S.; Mudd, G.; Haque, N. Assessing rare earth element mineral deposit types and links to environmental impacts. Appl. Earth Sci. 2013, 122, 83-96. [CrossRef]

24. Neupane, G.; Wendt, D.S. Assessment of mineral resources in geothermal brines in the us. In Proceedings of the 42nd Workshop on Geothermal Reservoir Engineering, Stanford University, Stanford, CA, USA, 13-15 February 2017.

25. Elderfield, H.; Greaves, M.J. The rare earth elements in seawater. Nature 1982, 296, 214-219. [CrossRef]

26. Haque, N.; Hughes, A.; Lim, S.; Vernon, C. Rare earth elements: Overview of mining, mineralogy, uses, sustainability and environmental impact. Resources 2014, 3, 614-635. [CrossRef]

27. Humphries, M. Rare earth elements: The global supply chain. Congr. Res. Serv. 2012, 2011, 7-5700.

28. Anderson, C.; Anderson, C.; Taylor, P. Survey of recycled rare earths metallurgical processing. Can. Metall. Q. 2013, 52, 249-256. [CrossRef]

29. Anderson, C.D.; Taylor, P.R.; Anderson, C.G. Rare Earth Floatation Fundamentals: A Review. In Proceedings of the XXVIII International Mineral Processing Congress 2016, Quebec City, QC, Canada, 11-15 September 2016.

30. Kronholm, B.; Anderson, C.G.; Taylor, P.R. A primer on hydrometallurgical rare earth separations. JOM 2013, 65, 1321-1326. [CrossRef]

31. Xie, F.; Zhang, T.A.; Dreisinger, D.; Doyle, F. A critical review on solvent extraction of rare earths from aqueous solutions. Miner. Eng. 2014, 56, 10-28. [CrossRef]

32. Faris, N.; Ram, R.; Tardio, J.; Bhargava, S.; McMaster, S.; Pownceby, M.I. Application of ferrous pyrometallurgy to the beneficiation of rare earth bearing iron ores-A review. Miner. Eng. 2017, 110, 20-30. [CrossRef]

33. Guo, L.; Chen, J.; Shen, L.; Zhang, J.; Zhang, D.; Deng, Y. Highly selective extraction and separation of rare earths(III) using bifunctional ionic liquid extractant. ACS Sustain. Chem. Eng. 2014, 2, 1968-1975. [CrossRef]

34. Sun, X.; Waters, K.E. Development of industrial extractants into functional ionic liquids for environmentally friendly rare earth separation. ACS Sustain. Chem. Eng. 2014, 2, 1910-1917. [CrossRef]

35. Krishnamurthy, N.; Gupta, C.K. Extractive Metallurgy of Rare Earths; CRC Press: Boca Raton, FL, USA, 2004.

36. Eyring, L. Progress in the Science and Technology of the Rare Earths; Elsevier: Amsterdam, The Netherlands, 2013.

37. Lucas, J.; Lucas, P.; Le Mercier, T.; Rollat, A.; Davenport, W.G. Rare Earths: Science, Technology, Production and Use; Elsevier: Amsterdam, The Netherlands, 2014.

38. Ali, S. Social and environmental impact of the rare earth industries. Resources 2014, 3, 123-134. [CrossRef]

39. Tharumarajah, R.; Koltun, P. Cradle to gate assessment of environmental impact of rare earth metals. In Proceedings of the 7th Australian Conference on Life Cycle Assessment, Melbourne, Australia, 9-10 March 2011.

40. Norgate, T.; Haque, N. Energy and greenhouse gas impacts of mining and mineral processing operations. J. Clean. Prod. 2010, 18, 266-274. [CrossRef]

41. Northey, S.; Haque, N.; Mudd, G. Using sustainability reporting to assess the environmental footprint of copper mining. J. Clean. Prod. 2013, 40, 118-128. [CrossRef]

42. Koltun, P.; Tharumarajah, A. Life cycle impact of rare earth elements. ISRN Metall. 2014, 2014. [CrossRef]

43. Gammons, C.H.; Wood, S.A.; Jonas, J.P.; Madison, J.P. Geochemistry of the rare-earth elements and uranium in the acidic Berkeley Pit lake, Butte, Montana. Chem. Geol. 2003, 198, 269-288. [CrossRef] 
44. Van Middlesworth, P.E.; Wood, S.A. The aqueous geochemistry of the rare earth elements and yttrium. Part 7. REE, Th and U contents in thermal springs associated with the idaho batholith. Appl. Geochem. 1998, 13, 861-884. [CrossRef]

45. Nelson, B.J.; Wood, S.A.; Osiensky, J.L. Rare earth element geochemistry of groundwater in the Palouse Basin, northern Idaho-eastern Washington. Geochem. Explor. Environ. Anal. 2004, 4, 227-241. [CrossRef]

46. Wood, S.A. The aqueous geochemistry of the rare-earth elements and yttrium: 1. Review of available low-temperature data for inorganic complexes and the inorganic ree speciation of natural waters. Chem. Geol. 1990, 82, 159-186. [CrossRef]

47. Wood, S.A.; Shannon, W.M. Rare-earth elements in geothermal waters from Oregon, Nevada, and California. J. Solid State Chem. 2003, 171, 246-253. [CrossRef]

48. Araki, K.; Yoshida, M.; Uezu, K.; Goto, M.; Furusaki, S. Lanthanide-imprinted resins prepared by surface template polymerization. J. Chem. Eng. Jpn. 2000, 33, 665-668. [CrossRef]

49. Alakhras, F.A.; Dari, K.A.; Mubarak, M.S. Synthesis and chelating properties of some poly(amidoximehydroxamic acid) resins toward some trivalent lanthanide metal ions. J. Appl. Polym. Sci. 2005, 97, 691-696. [CrossRef]

50. Bou-Maroun, E.; Goetz-Grandmont, G.J.; Boos, A. Sorption of europium(III) and copper(II) by a mesostructured silica doped with acyl-hydroxypyrazole derivatives-Extraction, kinetic and capacity studies. Colloids Surf. A 2006, 287, 1-9. [CrossRef]

51. Chen, Y.G.; Zhu, B.H.; Wu, D.B.; Wang, Q.G.; Yang, Y.H.; Ye, W.M.; Guo, J.F. Eu(III) adsorption using di(2-ethylhexyl) phosphoric acid-immobilized magnetic GMZ bentonite. Chem. Eng. J. 2012, 181, 387-396. [CrossRef]

52. Choi, S.H.; Lee, K.P.; Sohn, S.H. Graft copolymer-lanthanide complexes obtained by radiation grafting on polyethylene film. J. Appl. Polym. Sci. 2003, 87, 328-336. [CrossRef]

53. Das, N.; Das, D. Recovery of rare earth metals through biosorption: An overview. J. Rare Earths 2013, 31, 933-943. [CrossRef]

54. Dupont, D.; Brullot, W.; Bloemen, M.; Verbiest, T.; Binnemans, K. Selective uptake of rare earths from aqueous solutions by edta-functionalized magnetic and nonmagnetic nanoparticles. ACS Appl. Mater. Interfaces 2014, 6, 4980-4988. [CrossRef] [PubMed]

55. Jia, Q.; Wang, Z.H.; Li, D.Q.; Niu, C.J. Adsorption of heavy rare earth(III) with extraction resin containing bis(2,4,4-trimethylpentyl) monothiophosphinic acid. J. Alloys Compd. 2004, 374, 434-437. [CrossRef]

56. Ramakrishnan, K.; Rao, T.P. Ion imprinted polymer solid phase extraction (IIP-SPE) for preconcentrative separation of erbium(III) from adjacent lanthanides and yttrium. Sep. Sci. Technol. 2006, 41, 233-246. [CrossRef]

57. Shibata, J.; Matsumoto, S.; Yamamoto, H. A novel separation technology for a heavy rare earth residue using a solvent impregnated resin. Solvent Extr. Res. Dev. Jpn. 2000, 7, 167-175.

58. Wang, F.; Zhao, J.; Zhou, H.; Li, W.; Sui, N.; Liu, H. O-carboxymethyl chitosan entrapped by silica: Preparation and adsorption behaviour toward neodymium (III) ions. J. Chem. Technol. Biotechnol. 2013, 88, 317-325. [CrossRef]

59. Wu, D.; Sun, Y.; Wang, Q. Adsorption of lanthanum (III) from aqueous solution using 2-ethylhexyl phosphonic acid mono-2-ethylhexyl ester-grafted magnetic silica nanocomposites. J. Hazard. Mater. 2013, 260, 409-419. [CrossRef] [PubMed]

60. Ogata, T.; Narita, H.; Tanaka, M. Adsorption behavior of rare earth elements on silica gel modified with diglycol amic acid. Hydrometallurgy 2015, 152, 178-182. [CrossRef]

61. Koeppenkastrop, D.; De Carlo, E.H. Uptake of rare earth elements from solution by metal oxides. Environ. Sci. Technol. 1993, 27, 1796-1802. [CrossRef]

62. Ashour, R.M.; El-sayed, R.; Abdel-Magied, A.F.; Abdel-khalek, A.A.; Ali, M.; Forsberg, K.; Uheida, A.; Muhammed, M.; Dutta, J. Selective separation of rare earth ions from aqueous solution using functionalized magnetite nanoparticles: Kinetic and thermodynamic studies. Chem. Eng. J. 2017, 327, 286-296. [CrossRef]

63. Thomas, H.; Reinhardt, T.P.; Segneri, B. Low temperature geothermal mineral recovery program. In Proceedings of the 40th Workshop on Geothermal Reservoir Engineering, Stanford University, Stanford, CA, USA, 26-28 January 2015.

64. Thomas, H.P.; Reinhardt, T.P.; Andersen, A.; Segneri, B. Critical and strategic materials and potential importance for geothermal projects. In Proceedings of the 41st Workshop on Geothermal Reservoir Engineering, Stanford University, Stanford, CA, USA, 22-24 February 2016. 
65. Smith, Y.R.; Bhattacharyya, D.; Willhard, T.; Misra, M. Adsorption of aqueous rare earth elements using carbon black derived from recycled tires. Chem. Eng. J. 2016, 296, 102-111. [CrossRef]

66. Izatt, R.M.; Izatt, S.R.; Bruening, R.L.; Izatt, N.E.; Moyer, B.A. Challenges to achievement of metal sustainability in our high-tech society. Chem. Soc. Rev. 2014, 43, 2451-2475. [CrossRef] [PubMed]

67. Rao, S.R. Resource Recovery and Recycling from Metallurgical Wastes; Elsevier: Amsterdam, The Netherlands, 2011; Volume 7.

68. Sohn, H.Y. Hydrometallurgical principles. In Reference Module in Materials Science and Materials Engineering; Elsevier: Amsterdam, The Netherlands, 2016.

69. Izatt, N.E.; Bruening, R.L.; Krakowiak, K.E.; Izatt, S.R. Contributions of professor Reed M. Izatt to molecular recognition technology: From laboratory to commercial application. Ind. Eng. Chem. Res. 2000, 39, 3405-3411. [CrossRef]

70. Izatt, S.R.; Bruening, R.L.; Izatt, N.E. Metal separations and recovery in the mining industry. JOM 2012, 64, 1279-1284. [CrossRef]

71. Izatt, R.M. Charles J. Pedersen: Innovator in macrocyclic chemistry and co-recipient of the 1987 Nobel Prize in chemistry. Chem. Soc. Rev. 2007, 36, 143-147. [CrossRef] [PubMed]

72. Pedersen, C.J. Cyclic polyethers and their complexes with metal salts. J. Am. Chem. Soc. 1967, 89, 7017-7036. [CrossRef]

73. Izatt, R.M.; Nelson, D.; Rytting, J.; Haymore, B.; Christensen, J.J. Calorimetric study of the interaction in aqueous solution of several uni-and bivalent metal ions with the cyclic polyether dicyclohexyl-18-crown-6 at 10,25, and 40.deg. J. Am. Chem. Soc. 1971, 93, 1619-1623. [CrossRef]

74. Lamb, J.; Izatt, R.; Swain, C.; Christensen, J. A systematic study of the effect of macrocycle ring size and donor atom type on the log K, .DELTA.H, and T.DELTA.S of reactions at 25.degree.C in methanol of mono-and divalent cations with crown ethers. J. Am. Chem. Soc. 1980, 102, 475-479. [CrossRef]

75. Christensen, J.J.; Eatough, D.J.; Izatt, R.M. The synthesis and ion bindings of synthetic multidentate macrocyclic compounds. Chem. Rev. 1974, 74, 351-384. [CrossRef] [PubMed]

76. Izatt, R.; Lamb, J.; Bruening, R. Comparison of bulk, emulsion, thin sheet supported, and hollo fiber supported liquid membranes in macrocycle-mediated cation separations. Sep. Sci. Technol. 1988, 23, 1645-1658. [CrossRef]

77. Izatt, R.M.; Bruening, R.L.; Bruening, M.L.; Tarbet, B.J.; Krakowiak, K.E.; Bradshaw, J.S.; Christensen, J.J. Removal and separation of metal ions from aqueous solutions using a silica-gel-bonded macrocycle system. Anal. Chem. 1988, 60, 1825-1826. [CrossRef]

78. Izatt, R.M.; Izatt, S.R.; Izatt, N.E.; Krakowiak, K.E.; Bruening, R.L.; Navarro, L. Industrial applications of molecular recognition technology to separations of platinum group metals and selective removal of metal impurities from process streams. Green Chem. 2015, 17, 2236-2245. [CrossRef]

79. Gadd, G.M. Biosorption: Critical review of scientific rationale, environmental importance and significance for pollution treatment. J. Chem. Technol. Biotechnol. 2009, 84, 13-28. [CrossRef]

80. Vijayaraghavan, K.; Yun, Y.-S. Bacterial biosorbents and biosorption. Biotechnol. Adv. 2008, 26, $266-291$. [CrossRef] [PubMed]

81. Valls, M.; Atrian, S.; de Lorenzo, V.; Fernández, L.A. Engineering a mouse metallothionein on the cell surface of Ralstonia eutropha CH34 for immobilization of heavy metals in soil. Nat. Biotechnol. 2000, 18, 661-665. [CrossRef] [PubMed]

82. Kuroda, K.; Ueda, M. Bioadsorption of cadmium ion by cell surface-engineered yeasts displaying metallothionein and hexa-His. Appl. Microbiol. Biotechnol. 2003, 63, 182-186. [CrossRef] [PubMed]

83. Nishitani, T.; Shimada, M.; Kuroda, K.; Ueda, M. Molecular design of yeast cell surface for adsorption and recovery of molybdenum, one of rare metals. Appl. Microbiol. Biotechnol. 2010, 86, 641-648. [CrossRef] [PubMed]

84. Pazirandeh, M.; Chrisey, L.; Mauro, J.; Campbell, J.; Gaber, B. Expression of the neurospora crassa metallothionein gene in escherichia coli and its effect on heavy-metal uptake. Appl. Microbiol. Biotechnol. 1995, 43, 1112-1117. [CrossRef] [PubMed]

85. Park, D.M.; Reed, D.W.; Yung, M.C.; Eslamimanesh, A.; Lencka, M.M.; Anderko, A.; Fujita, Y.; Riman, R.E.; Navrotsky, A.; Jiao, Y. Bioadsorption of rare earth elements through cell surface display of lanthanide binding tags. Environ. Sci. Technol. 2016, 50, 2735-2742. [CrossRef] [PubMed]

86. Daughtry, K.D.; Martin, L.J.; Sarraju, A.; Imperiali, B.; Allen, K.N. Tailoring encodable lanthanide-binding tags as MRI contrast agents. Chem. Biol. Chem. 2012, 13, 2567-2574. [CrossRef] [PubMed] 
87. Charrier, M.; Ajo-Franklin, C.M. Engineering thermophilic microorganisms to selectively extract strategic minerals. In Proceedings of the 42nd Workshop on Geothermal Reservoir Engineering, Stanford University, Stanford, CA, USA, 13-15 February 2017.

88. Lo, Y.C.; Cheng, C.L.; Han, Y.L.; Chen, B.Y.; Chang, J.S. Recovery of high-value metals from geothermal sites by biosorption and bioaccumulation. Bioresour. Technol. 2014, 160, 182-190. [CrossRef] [PubMed]

89. O'brien, T.B. Recovery of Elements from Hydrothermal Products. U.S. Patent 8377165, 19 February 2013.

90. Werner, H. Contribution to the mineral extraction from supersaturated geothermal brines salton sea area, California. Geothermics 1970, 2, 1651-1655. [CrossRef]

91. Kennedy, A. The recovery of lithium and other minerals from geothermal water at Wairakei. In Proceedings of the UN Conference on New Sources of Energy, Rome, Italy, 21-31 August 1961.

92. Maimoni, A. Minerals recovery from salton sea geothermal brines-A literature review and proposed cementation process. Geothermics 1982, 11, 239-258. [CrossRef]

93. Harrison, S. Technologies for Extracting Valuable Metals and Compounds from Geothermal Fluids; California Energy Commission: Sacramento, CA, USA, 2014.

94. Wood, S.A. Behavior of Rare Earth Element in Geothermal Systems; A New Exploration/Exploitation Tool; University of Idaho (US): Moscow, ID, USA, 2002.

95. Bourcier, W.; Bruton, C.; Roberts, S.; Viani, B.; Conley, S.; Martin, S. Pilot-Scale Geothermal Silica Recovery at Mammoth Lakes; California Energy Commission: Sacramento, CA, USA, 2009.

96. Farley, E.; Watson, E.; MacDonald, D.; Bartlett, R.; Krishnan, G. Recovery of Heavy Metals from High Salinity Geothermal Brine; SRI International: Menlo Park, CA, USA, 1980.

97. Brown, K.L.; Roberts, P.J.C. Extraction of gold and silver from geothermal fluid. In Proceedings of the 10th New Zealand Geothermal Workshop, Auckland, New Zealand, 2-4 November 1988.

98. Brown, K.L. Gold deposition from geothermal discharges in New Zealand. Econ. Geol. 1986, 81, 979-983. [CrossRef]

99. Premuzic, E.T.; Lin, M.S.; Bohenek, M.; Bajsarowicz, V.; McCloud, M. Advanced Biochemical Processes for Geothermal Brines: Current Developments; Brookhaven National Lab.: Upton, NY, USA, 1997.

100. Gallup, D.L.; Ririe, G.T. Platinum Recovery. U.S. Patent 5290339, 1 March 1994.

101. Christopher, D.; Stewart, M.; Rice, J. The Recovery and Separation of Mineral Values from Geothermal Brines. Research Report, 1974-1975; Hazen Research, Inc.: Golden, CO, USA, 1975.

102. Gambogi, J. Rare earths. In 2014 Minerals Yearbook; U.S. Gological Survey: Reston, VA, USA, 2016.

103. Gambogi, J. Gold. In 2014 Minerals Yearbook; U.S. Gological Survey: Reston, VA, USA, 2016.

104. Moore, J. Personal communication, Energy \& Geoscience Institute: Salt Lake City, UT, USA, 2017.

(C) 2017 by the authors. Licensee MDPI, Basel, Switzerland. This article is an open access article distributed under the terms and conditions of the Creative Commons Attribution (CC BY) license (http:/ / creativecommons.org/licenses/by/4.0/). 


\title{
Article \\ Speculations Linking Monazite Compositions to Origin: Llallagua Tin Ore Deposit (Bolivia)
}

\author{
Elizabeth J. Catlos * and Nathan R. Miller \\ Department of Geological Sciences, Jackson School of Geosciences, The University of Texas at Austin, \\ 1 University Sta. C9000, EPS 1.130, Austin, TX 78712, USA; nrmiller@jsg.utexas.edu \\ * Correspondence: ejcatlos@jsg.utexas.edu; Tel.: +1-512-471-4762
}

Received: 3 May 2017; Accepted: 25 July 2017; Published: 29 July 2017

\begin{abstract}
Monazite $\left[(\mathrm{Ce}, \mathrm{Th}) \mathrm{PO}_{4}\right]$ from the Llallagua tin ore deposit in Bolivia is characterized by low radiogenic element contents. Previously reported field evidence and mineral associations suggest the mineral formed via direct precipitation from hydrothermal fluids. Monazite compositions thus may provide insight into characteristics of the fluids from which it formed. Chemical compositions of three Llallagua monazite grains were obtained using Electron Probe Microanalysis (EPMA, $n=64$ ) and laser ablation mass spectrometry (LA-ICP-MS, $n=56$ ). The mineral has higher amounts of $\mathrm{U}$ $(123 \pm 17 \mathrm{ppm})$ than Th $(39 \pm 20 \mathrm{ppm})(\mathrm{LA}-\mathrm{ICP}-\mathrm{MS}, \pm 1 \sigma)$. Grains have the highest amounts of fluorine ever reported for monazite $(0.88 \pm 0.10 \mathrm{wt} \%$, EPMA, $\pm 1 \sigma)$, and F-rich fluids are effective mobilizers of rare earth elements (REEs), Y, and Th. The monazite has high Eu contents and positive $\mathrm{Eu}$ anomalies, consistent with formation in a highly-reducing back-arc environment. We speculate that F, Ca, Si and REE may have been supplied via dissolution of pre-existing fluorapatite. Llallagua monazite oscillatory zoning is controlled by an interplay of low $(\mathrm{P}+\mathrm{Ca}+\mathrm{Si}+\mathrm{Y})$ and high atomic number (REE) elements. We suggest monazite compositions provide insight into fluid geochemistry, mineral reactions, and tectonic settings of ore deposits that contain the mineral.
\end{abstract}

Keywords: monazite; rare earth elements; geochemistry; Bolivia; apatite; Llallagua

\section{Introduction}

The Llallagua ore deposit is part of the tin belt that extends from southern Peru to northern Argentina (Figure 1) (e.g., [1,2]). The region was once considered one of the largest hard-rock tin deposits in the world, and produced more than 0.5 million tons of metallic tin [3-7]. The richest ore deposits are located within a zone where the belt makes a sharp curve (Figure 1) and are commonly found in association with intrusive igneous rocks $[1,2,4-10]$.

Monazite $\left[(\mathrm{Ce}, \mathrm{Th}) \mathrm{PO}_{4}\right]$ is found in almost every vein system in the Llallagua deposit in association with quartz, cassiterite, tourmaline in veins and vugs, and embedded in pyrite and marcasite [5]. The mineral occurs as prismatic or pyramidal crystals with contact or penetration twinning [6]. The Llallagua monazite is also known for oscillatory zoning in backscattered electrons (BSE) (Figure 2) [7,11]. This type of zoning is considered rare for the mineral, which is more commonly seen as sector zoned in BSE [12-14].

Numerous studies describing the mineralogy of the Llallagua mine have noted the importance of fluids in the formation of the Llallagua monazite (e.g., $[5,6,15])$ and its composition has the potential to provide important insight into the geochemistry of the fluids that formed the deposit. 


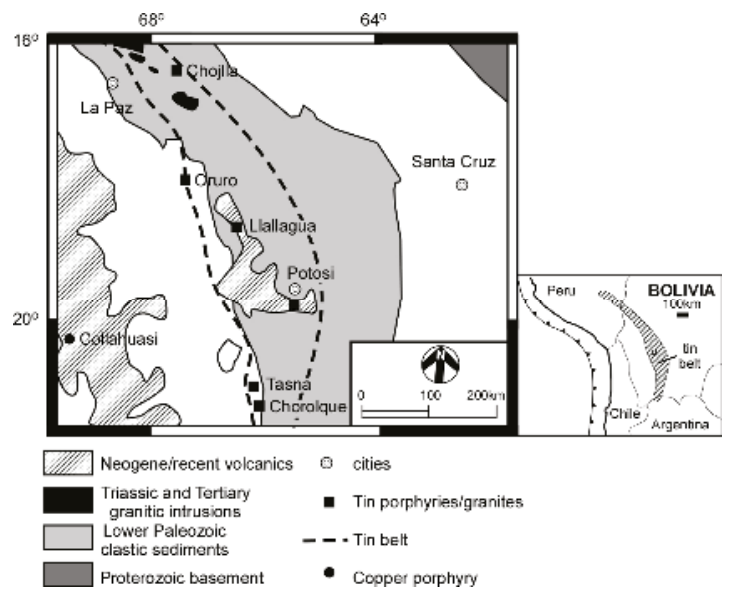

Figure 1. Geological map and cross-section of the La Joya mining district after [16]. Inset shows the location of the mining district within the tin belt of Bolivia, Peru, and Argentina after [7].

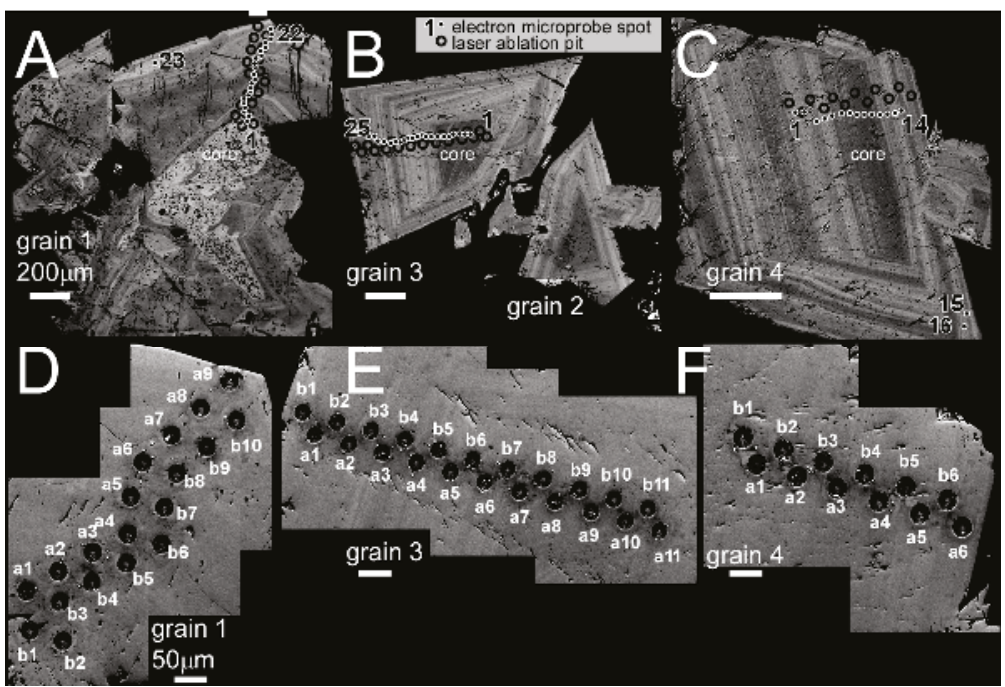

Figure 2. Backscattered electron (BSE) images of Llallagua monazite: (A) grain 1; (B) grains 2 and 3; and (C) grain 4. Electron probe microanalysis (EPMA) and laser ablation pits are indicated with some spot numbers labeled for reference. Secondary electron (SE) images showing laser ablation pits of Llallagua monazite: (D) grain 1; (E) grain 3; and (F) grain 4. Pits are labeled. See the Supplementary Materials, File S1 for compositions.

The origin of the Bolivian tin belt is suggested to be a series of compressional events between the Farallon/Nazca oceanic plate and the South American continent, which generated peraluminous magmas that equilibrated with graphite-rich, metapelitic sources [4,17]. The environment is characterized by low oxygen fugacity and high dissolved concentrations of tin (see review in [2]). The region was part of a back-arc basin for most of its history, but two major metallogenic episodes are recorded during the late Triassic-early Jurassic and late Oligocene-early Miocene [18,19]. Based on its ages, the Llallagua monazite analyzed in this study belongs to the second event. 
Monazite from the Llallagua deposit contains minor Th, $\mathrm{U}[5,7,11,15,20]$ and up to $99.9 \%$ common ${ }^{206} \mathrm{~Pb}$ [7]. Monazite is thought to exclude common Pb during crystallization (e.g., [20-23]). Despite this issue, monazite from the Llallagua mine has been dated using $\mathrm{U}-\mathrm{Pb}$ methods and yields Miocene results at $23.4 \pm 2.2 \mathrm{Ma}$ [7] and $19.0 \pm 1.6 \mathrm{Ma}$ [11]. These results are in-line with Miocene K-Ar ages of "partially altered" [24] Llallagua quartz latite porphyry minerals (20.6 $\pm 0.4 \mathrm{Ma}$, K-feldspar; and $21.6 \pm 0.4 \mathrm{Ma}$, biotite) [17]. However, they are much younger than Eocene crystallization ages reported from the same locality $[15,24,25]$. The reason for the wide range of ages is problematic because a genetic link between tin ore mineralization and proximal igneous intrusions has yet to be established. The composition and timing of fluids transporting and depositing the ore is important information for evaluation and exploitation of this deposit and others like it (e.g., [26,27]).

Here we present detailed compositional analyses from three Llallagua monazite grains to understand how it reflects on its tectonic setting and controls on zoning. Because monazite can incorporate a wide variety of elements into its structure, and thus may have variable stoichiometry, generating high quality compositional data from monazite can be challenging [28-30]. We apply both electron probe microanalysis (EPMA) and laser ablation-inductively coupled plasma mass spectrometry (LA-ICP-MS) to constrain what elements are present in its structure. The grains were obtained from a vein in the Llallagua tin-ore porphyry deposit, provided by Alfredo Petrov (mindat.org [6]) from a sample dated by [11]. Our only geological context is that the grains were collected from a vein in a tin mine in the Potosi Department (Figure 1). Although the sample set is small $(n=3)$, we obtained a large amount of high-quality chemical analyses $(n=120)$ and the monazite themselves have previous age constraints [11]. The monazite compositions have the potential to allow insight into mineral reactions that may have occurred as the tin deposit formed. The Llallagua region is a historically important mining district, and the data is used to compare to those from other important monazite ore-producing localities to explore its potential as a resource for rare earth element (REEs).

\section{Analytical Approaches}

\subsection{Sample Preparation and Imaging}

The analyses were taken using the same standards and approach described in [28]. We followed a sample preparation protocol that would be typical for instruments that require polished monazite grains in a mounted environment (i.e., EPMA, ion microprobe, LA-ICP-MS). Individual grains were placed on dual-sided tape. A 1-inch diameter Teflon ring was placed around the grains and epoxy (Beuhler, EpoxiCure 2 Epoxy System) was poured around the grains to a depth of $\sim 10 \mathrm{~mm}$. After the epoxy cured, rings were broken away from the tape and grains polished using sand paper and Mother's Billet Metal Polish. The back of the plug was cut using a high-precision saw to a thickness of $\sim 5 \mathrm{~mm}$. During this process, grains were exposed to Allied Low Speed Cutting Fluid. Mounts were cleaned in a sonicator bath with distilled water and an ultrasonic cleanser for $5 \mathrm{~min}$ and followed by three sessions of $5 \mathrm{~min}$ each in pure distilled water to remove traces of the cleanser or other impurities.

\subsection{Llallagua Monazite Electron Probe MicroAnalyses (EPMA)}

Mounts were coated in carbon and imaged using the University of Oklahoma Cameca SX50 electron probe micro-analyzer equipped with five wavelength-dispersive $\mathrm{X}$-ray spectrometers, integrated energy-dispersive X-ray analyzer, standard Secondary Electron Microscope (SEM) imaging capabilities. The instrument operated at a $20 \mu \mathrm{kV}$ accelerating voltage, $20 \mathrm{nA}$ current and a $2 \mu \mathrm{m}$ spot size. These conditions were also maintained for the compositional analyses. Grains were imaged in backscattered electrons (BSE) to understand their zoning, potential compositional variations, and to select regions for quantitative analysis using EPMA and laser techniques (Figure 2). Analytical protocols followed methods developed by [30] and G. Morgan (personal communication) for xenotime with the exception that $\mathrm{Pb}$ was analyzed using the $\mathrm{M} \alpha$ emission rather than $\mathrm{M} \beta$, as the $\mathrm{M} \alpha$ line was 
slightly better at resolving interferences. The element, X-ray emissions and diffracting crystals for analyses are listed in Table 1.

Table 1. Conditions used for quantitative monazite compositional analysis.

\begin{tabular}{ccc}
\hline Element(s) & Crystal & X-ray Line \\
\hline $\mathrm{P}, \mathrm{S}, \mathrm{Ca}, \mathrm{Cl}$ & $\mathrm{PET}$ & $\mathrm{K} \alpha$ \\
$\mathrm{As}, \mathrm{Ti}, \mathrm{Fe}, \mathrm{Mn}$ & $\mathrm{LIF}$ & $\mathrm{K} \alpha$ \\
$\mathrm{Al}, \mathrm{Si}, \mathrm{Mg}, \mathrm{Na}, \mathrm{F}$ & $\mathrm{TAP}$ & $\mathrm{K} \alpha$ \\
Y & $\mathrm{TAP}$ & $\mathrm{L} \alpha$ \\
$\mathrm{La}, \mathrm{Ce}, \mathrm{Nd}, \mathrm{Eu}, \mathrm{Tb}$ & $\mathrm{LIF}$ & $\mathrm{L} \alpha$ \\
$\mathrm{Pr}, \mathrm{Sm}, \mathrm{Gd}$ & $\mathrm{LIF}$ & $\mathrm{L} \beta$ \\
$\mathrm{Th}$ & $\mathrm{PET}$ & $\mathrm{M} \alpha$ \\
$\mathrm{U}$ & $\mathrm{PET}$ & $\mathrm{M} \beta$ \\
\hline
\end{tabular}

Standards for REEs were ternary rare earth orthophosphates (REP) described by [30]. Durango fluorapatite [31] was used for $\mathrm{Ca}$, galena for $\mathrm{Pb}$, and synthetic $\mathrm{ThO}_{2}$ and depleted pure uranium metal (C.M. Taylor Corp.) was used for Th and U. Natural and synthetic crystalline solids were used for remaining elements. Note that phosphate standards are not available for all desired elements, thus we relied on a variety of standards. Counting times were $30 \mathrm{~s}$ on peak for all elements, except $\mathrm{Mg}$ and $\mathrm{Si}$, which were $60 \mathrm{~s}$ each. Each background was counted for half the time of the peak, therefore total time on background equaled that of the peak. An overlap correction was applied for the Pr L $\alpha$ emission on the Eu L $\alpha$ line using the Pr-bearing Rare Earth Phosphate standard-2 (REP2) and analytical methods exactly the same as for $\mathrm{Eu} \mathrm{L} \alpha$. Each analysis required $\sim 15 \mathrm{~min}$. Standards analyzed as unknowns were only measured at the beginning of the analytical session because the beam current did not drift more than $0.2 \mathrm{nA}$, the laboratory temperature is stable $\left( \pm 1^{\circ} \mathrm{F}\right)$, and compositional data fit the monazite formula (Table 2, Figure 3).

Table 2. Average Llallagua monazite EPMA compositions ${ }^{1}$.

\begin{tabular}{ccccc}
\hline Analysis & Grain $\mathbf{1}(\boldsymbol{n}=\mathbf{2 3})^{2}$ & Grain $\mathbf{3}(\boldsymbol{n}=\mathbf{2 5 )}$ & Grain $\mathbf{4}(\boldsymbol{n}=\mathbf{1 6})$ & All Grains $(\boldsymbol{n}=\mathbf{6 4})$ \\
\hline $\mathrm{P}_{2} \mathrm{O}_{5}(\mathrm{wt} \%)^{3}$ & $30.1(0.7)$ & $29.9(0.4)$ & $29.9(0.4)$ & $29.97(0.51)$ \\
$\mathrm{As}_{2} \mathrm{O}_{5}$ & $0.02(0.04)$ & $0.02(0.03)$ & $0.04(0.07)$ & $0.03(0.05)$ \\
$\mathrm{SiO}_{2}$ & $0.151(0.027)$ & $0.185(0.024)$ & $0.182(0.024)$ & $0.17(0.03)$ \\
$\mathrm{TiO}_{2}$ & $0.010(0.016)$ & $0.012(0.018)$ & $0.006(0.015)$ & $0.01(0.02)$ \\
$\mathrm{UO}_{2}$ & $0.031(0.043)$ & $0.033(0.053)$ & $0.041(0.035)$ & $0.03(0.05)$ \\
$\mathrm{Y}_{2} \mathrm{O}_{3}$ & $2.1(0.9)$ & $2.0(0.3)$ & $2.1(0.4)$ & $2.07(0.59)$ \\
$\mathrm{La}_{2} \mathrm{O}_{3}$ & $16.1(1.7)$ & $14.3(0.7)$ & $14.5(1.4)$ & $14.97(1.54)$ \\
$\mathrm{Ce}_{2} \mathrm{O}_{3}$ & $32.2(1.0)$ & $32.7(0.8)$ & $32.7(0.7)$ & $32.54(0.87)$ \\
$\mathrm{Pr}_{2} \mathrm{O}_{3}$ & $2.97(0.19)$ & $3.21(0.20)$ & $3.23(0.13)$ & $3.13(0.22)$ \\
$\mathrm{Nd}_{2} \mathrm{O}_{3}$ & $11.2(0.8)$ & $12.4(0.7)$ & $12.3(0.7)$ & $11.92(0.91)$ \\
$\mathrm{Sm}_{2} \mathrm{O}_{3}$ & $1.15(0.17)$ & $1.19(0.22)$ & $1.22(0.15)$ & $1.18(0.19)$ \\
$\mathrm{Eu} \mathrm{O}_{3}$ & $1.01(0.22)$ & $0.99(0.16)$ & $0.97(0.07)$ & $0.99(0.17)$ \\
$\mathrm{Gd}_{2} \mathrm{O}_{3}$ & $0.67(0.12)$ & $0.72(0.15)$ & $0.64(0.15)$ & $0.68(0.14)$ \\
$\mathrm{Tb}_{2} \mathrm{O}_{3}$ & $0.06(0.05)$ & $0.08(0.05)$ & $0.05(0.04)$ & $0.06(0.05)$ \\
$\mathrm{CaO}$ & $0.53(0.32)$ & $0.59(0.45)$ & $0.63(0.32)$ & $0.58(0.37)$ \\
$\mathrm{F}$ & $0.87(0.09)$ & $0.88(0.11)$ & $0.92(0.09)$ & $0.88(0.10)$ \\
$\mathrm{Cl}$ & $0.06(0.01)$ & $0.06(0.01)$ & $0.06(0.01)$ & $0.06(0.01)$ \\
$\mathrm{Total}_{\mathrm{P}}(\mathrm{apfu})^{5}$ & $98.8(0.9)$ & $98.9(0.6)$ & $99.1(0.5)$ & $98.90(0.7)$ \\
$\mathrm{Si}$ & $0.999(0.009)$ & $0.995(0.004)$ & $0.994(0.005)$ & $0.996(0.007)$ \\
$\mathrm{Y}$ & $0.006(0.001)$ & $0.007(0.001)$ & $0.007(0.001)$ & $0.007(0.001)$ \\
$\mathrm{La}$ & $0.044(0.018)$ & $0.042(0.006)$ & $0.043(0.007)$ & $0.043(0.012)$ \\
$\mathrm{Ce}$ & $0.233(0.026)$ & $0.207(0.011)$ & $0.209(0.021)$ & $0.217(0.023)$ \\
$\mathrm{Pr}$ & $0.462(0.019)$ & $0.471(0.012)$ & $0.471(0.009)$ & $0.468(0.014)$ \\
& $0.042(0.003)$ & $0.046(0.003)$ & $0.046(0.002)$ & $0.045(0.003)$ \\
\hline
\end{tabular}


Table 2. Cont.

\begin{tabular}{ccccc}
\hline Analysis & Grain $\mathbf{1}\left(\boldsymbol{n = 2 3 ) ^ { 2 }}\right.$ & Grain $\mathbf{3}(\boldsymbol{n = 2 5 )}$ & Grain $\mathbf{4}(\boldsymbol{n = 1 6 )}$ & All Grains $(\boldsymbol{n}=\mathbf{6 4})$ \\
\hline $\mathrm{Nd}$ & $0.156(0.011)$ & $0.174(0.010)$ & $0.172(0.010)$ & $0.167(0.013)$ \\
$\mathrm{Sm}$ & $0.016(0.002)$ & $0.016(0.003)$ & $0.017(0.002)$ & $0.016(0.003)$ \\
$\mathrm{Eu}$ & $0.013(0.003)$ & $0.013(0.002)$ & $0.013(0.001)$ & $0.013(0.002)$ \\
$\mathrm{Gd}$ & $0.009(0.001)$ & $0.009(0.002)$ & $0.008(0.002)$ & $0.009(0.002)$ \\
$\mathrm{Ca}$ & $0.022(0.013)$ & $0.025(0.019)$ & $0.026(0.013)$ & $0.024(0.016)$ \\
$\mathrm{F}$ & $0.108(0.011)$ & $0.109(0.013)$ & $0.114(0.011)$ & $0.110(0.012)$ \\
$\mathrm{Cl}$ & $0.004(0.001)$ & $0.004(0.001)$ & $0.004(0.001)$ & $0.004(0.001)$ \\
Total & $2.01(0.01)$ & $2.01(0.01)$ & $2.01(0.005)$ & $2.01(0.005)$ \\
\hline
\end{tabular}

${ }^{1}$ Measured but not detected: $\mathrm{SO}_{3}, \mathrm{PbO}, \mathrm{FeO}, \mathrm{MnO}, \mathrm{MgO}, \mathrm{Na}_{2} \mathrm{O}, \mathrm{ThO}_{2}$ and $\mathrm{Al}_{2} \mathrm{O}_{3}$ (wt \%). Supplementary Materials, File $\mathrm{S} 1$ contains details regarding each analysis and standard data. See Figure 2 for locations; ${ }^{2} n=$ number of spots on monazite grain; ${ }^{3}$ Oxides and halogens in this groups reported in $\mathrm{wt} \%{ }^{4}$ Number in parentheses is $1 \sigma$ standard deviation of the average in absolute values; ${ }^{5}$ Atoms per formula unit (apfu) are normalized to four oxygens.
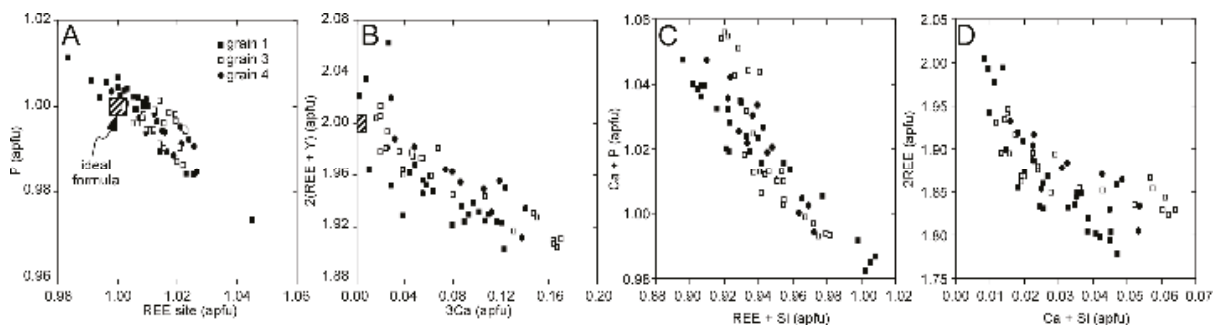

Figure 3. Plot of monazite EPMA compositions (see Supplementary Materials, File S1): (A) Rare Earth Element (REE) (atoms per formula unit, apfu) vs. P (apfu); (B) 3Ca (apfu) vs. 2(REE + Y) (apfu); (C) REE $+\mathrm{Si}(\mathrm{apfu})$ vs. Ca + P (apfu); and (D) Ca + Si vs. 2REE (apfu). Box in panels A and B indicates the region of ideal monazite formula. REE are $\mathrm{La}, \mathrm{Ce}, \mathrm{Pr}, \mathrm{Nd}, \mathrm{Sm}, \mathrm{Eu}, \mathrm{Gd}$, and $\mathrm{Tb}$.

\subsection{Llallagua Monazite LA-ICP-MS Analyses}

LA-ICP-MS major, minor, and trace element transects of monazite grains were performed at the University of Texas at Austin using a New Wave UP193fx (193 nm, 4-6 ns pulse width) excimer laser coupled to an Agilent 7500ce ICP-MS. Tracks for the laser pits were positioned proximal and parallel to the previously measured EPMA grain transects (Figure 2). Laser ablation parameters optimized from monazite test ablations were $45 \mathrm{~s}$ ablations using a $25 \mu \mathrm{m}$ diameter spot size at $45 \%$ power (fluence of $\sim 4.9 \mathrm{~J} / \mathrm{cm}^{2}$ ), $10 \mathrm{~Hz}$ repetition rate, and a He cell flow of $250 \mathrm{~mL} / \mathrm{min}$. Pulse-to-pulse laser power variation was $<3.5 \%$ over the analysis period. All spots were pre-ablated for $2 \mathrm{~s}$ using a $75 \mu \mathrm{m}$ spot, $20 \%$ laser power, and $10 \mathrm{~Hz}$ repletion rate to remove surface contamination (i.e., EPMA carbon coat). The quadrupole time-resolved method involved measurement of 22 analytes at one point per spectral peak, using the integration times of $10 \mathrm{~ms}\left({ }^{31} \mathrm{P}\right.$ and $\left.{ }^{89} \mathrm{Y}\right), 20 \mathrm{~ms}\left({ }^{23} \mathrm{Na},{ }^{27} \mathrm{Al},{ }^{47} \mathrm{Ti},{ }^{55} \mathrm{Mn}\right.$, ${ }^{57} \mathrm{Fe},{ }^{75} \mathrm{As},{ }^{137} \mathrm{Ba},{ }^{153} \mathrm{Eu},{ }^{157} \mathrm{Gd},{ }^{159} \mathrm{~Tb},{ }^{163} \mathrm{Dy},{ }^{165} \mathrm{Ho},{ }^{166} \mathrm{Er},{ }^{169} \mathrm{Tm},{ }^{172} \mathrm{Yb}$, and $\left.{ }^{175} \mathrm{Lu}\right)$ or $30 \mathrm{~ms}\left({ }^{204} \mathrm{~Pb}\right.$, ${ }^{208} \mathrm{~Pb},{ }^{232} \mathrm{Th}$, and ${ }^{238} \mathrm{U}$ ). The resulting sampling period (0.5062 s) corresponded to $>90 \%$ detection time, enabling 118 measurements to be made within the dwell interval ( $60 \mathrm{~s})$, conditions suitable for robust measurement [32]. A $45 \mathrm{~s}$ gas blank interval was used between all laser measurements.

Monazite analyses were bracketed hourly by triplicate analyses of laser ablation standards NIST-612 and NIST-610 [33] and USGS MAPS-4. See [34,35] for evaluations of the quality of the NIST-612 and NIST-610 glasses. Elemental concentrations were derived with the Iolite software [36] using MAPS-4 as the primary calibration standard and ${ }^{31} \mathrm{P}$ as the internal standard reference. Monazite P concentrations were assigned based on EPMA $\mathrm{P}_{2} \mathrm{O}_{5}$ analyses. MAPS- 4 is a synthetic trace element-doped $\mathrm{Ca}_{3}\left(\mathrm{PO}_{4}\right)_{2}$ precipitate [37] with a P content $(16.7 \pm 1.7 \mathrm{wt} \%)$ reasonably similar to the monazite (11.94 wt \% from EPMA). Average analyte recoveries were better for NIST-610 (128\%) 
than NIST-612 (156\%), but we consider these to be worst case estimates of accuracy considering that the P contents of these standards are $\sim 5000$ and $\sim 30,000$ times lower than MAPS-4. Analyte concentrations for monazite ablations were predominantly 100 to 1000 times higher than estimated detection limits, and signals for ${ }^{204} \mathrm{~Pb}$ were 40 to 155 times higher than detection limits.

Both the EPMA and LA-ICP-MS targeted a wide range of possible elements present in the monazite structure, and both approaches report $\mathrm{As}, \mathrm{Th}, \mathrm{U}, \mathrm{Al}, \mathrm{Y}, \mathrm{Pb}, \mathrm{Eu}, \mathrm{Gd}, \mathrm{Tb}, \mathrm{Fe}, \mathrm{Mn}$, and $\mathrm{Na}$ contents. A direct comparison of the chemical data for these elements obtained using both LA-ICP-MS and EPMA is inappropriate, however, as significant differences exist in terms of sampling region and detection limits. The EPMA approach relies on the analysis of oxides and halides from the surface of the monazite using X-ray element lines emitted from the mineral structure as a region of the grain was targeted with a $2 \mu \mathrm{m}$ electron beam, whereas the LA-ICP-MS obtained chemical data sputtered from a $25 \mu \mathrm{m}$-diameter circular spot following pre-ablation, and thus data arises from a deeper levels of the mineral not visible in BSE. In some cases, the laser spot overlaps zones of varying brightness or regions where more than one EPMA analysis was obtained (Figure 2). It is appropriate, however, to search for systematic variations. All compositional data and coordinates are available in Supplementary Materials, File S1

Following LA-ICP-MS, grains were re-imaged in secondary electrons (SE) using a JEOL JSM-6490LV SEM at the University of Texas at Austin, Dept. of Geological Sciences. This instrument operated at low vacuum mode, $15 \mathrm{kV}$ accelerating voltage, and a $2 \mu \mathrm{m}$ spot size. The goal was to identify any ablation craters that intersected secondary alteration features, deformation textures, or microcracks (defined as $>5 \mu \mathrm{m}$ in width). Regions that contain microcracks were examined to compare pre- and post-ablation to ascertain if their origin was due to the laser or are intrinsic to the grain. All imaged spots are seen in Figure 2D-F.

\section{Results}

\subsection{Llallagua Monazite EPMA}

Each grain shows oscillatory zoning in BSE (Figure 2), but grain 1 has a bright core, whereas grains 3 and 4 have darker cores. Note that what we define as the mineral core is our best approximation that represents the center of the grains, which may not be precisely exposed. The Llallagua monazite EPMA analyses support stoichiometry close to the ideal mineral formula (Figure 3A,B). The mineral contains $\mathrm{Ce}_{2} \mathrm{O}_{3}>\mathrm{La}_{2} \mathrm{O}_{3}>\mathrm{Nd}_{2} \mathrm{O}_{3}>\mathrm{Pr}_{2} \mathrm{O}_{3}>\mathrm{Y}_{2} \mathrm{O}_{3}>\mathrm{Sm}_{2} \mathrm{O}_{3}>\mathrm{Eu}_{2} \mathrm{O}_{3}>\mathrm{Gd}_{2} \mathrm{O}_{3}>\mathrm{Tb}_{2} \mathrm{O}_{3}$ (wt \%). As expected, concentrations of $\mathrm{ThO}_{2}$ and $\mathrm{UO}_{2}$ (wt \%) are below detection limits with the EPMA methods used (0.18 and $0.13 \mathrm{wt} \%$, respectively). Other oxides present at or below detection are $\mathrm{As}_{2} \mathrm{O}_{5}, \mathrm{TiO}_{2}, \mathrm{Al}_{2} \mathrm{O}_{3}, \mathrm{SO}_{3}$, $\mathrm{PbO}, \mathrm{FeO}, \mathrm{MnO}, \mathrm{MgO}, \mathrm{Na}_{2} \mathrm{O}$, and $\mathrm{Cl}$ (Table 2).

Silicon is present in the Llallagua samples at levels $<0.2 \mathrm{wt} \% \mathrm{SiO}_{2}$ (Table 2). The huttonite substitution mechanism for the incorporation of Th in monazite involves Si (ThSiREE ${ }_{-1} \mathrm{P}_{-1}$ ) [38]. However, this mechanism is inappropriate for these grains, as the Llallagua monazite contains undetectable amounts of radiogenic elements. Additionally, the monazite contains $0.58 \pm 0.37 \mathrm{wt} \% \mathrm{CaO}$ (Table 2; Figure 4A-C) suggesting a slight modification of the brabanite exchange vector $\left(\mathrm{Ca}_{3} \mathrm{REE}_{-2}\right.$ vs. CaThUREE_2) (Figure 3B). This substitution occurs in apatite with a vacancy [39]. Other substitutions that occur in apatite that also appear relevant to this monazite include $\mathrm{CaPREE}_{-1} \mathrm{Si}_{-1}$ and $\mathrm{CaSiREE}_{-2}$ (Figure 3C,D).

We detected higher amounts of fluorine in the monazite (average $0.88 \pm 0.10 \mathrm{wt} \%$ ) (Table 2, Figure 4A-C), an element commonly found in apatite [40-42]. We found no clear relationship between the amount of $\mathrm{F}$ and any cations, perhaps due to its substitution in the anion site or interstitial sites in the monazite structure, creating a degree of disorder. The amount of F does not vary significantly across the monazite grains (Figure $4 \mathrm{~A}-\mathrm{C}$ ). We exclude the possibility that $\mathrm{F}$ is an analytical artifact, as a monazite grain from the Amelia pegmatite was analyzed using the exact procedure and did not detect F, which would be expected if problematic conditions arose with standards or choice of background 
and peak [28]. Note that using the TAP monochromator, the F K $\alpha$ line is effectively free of any overlaps among the analyzed elements.
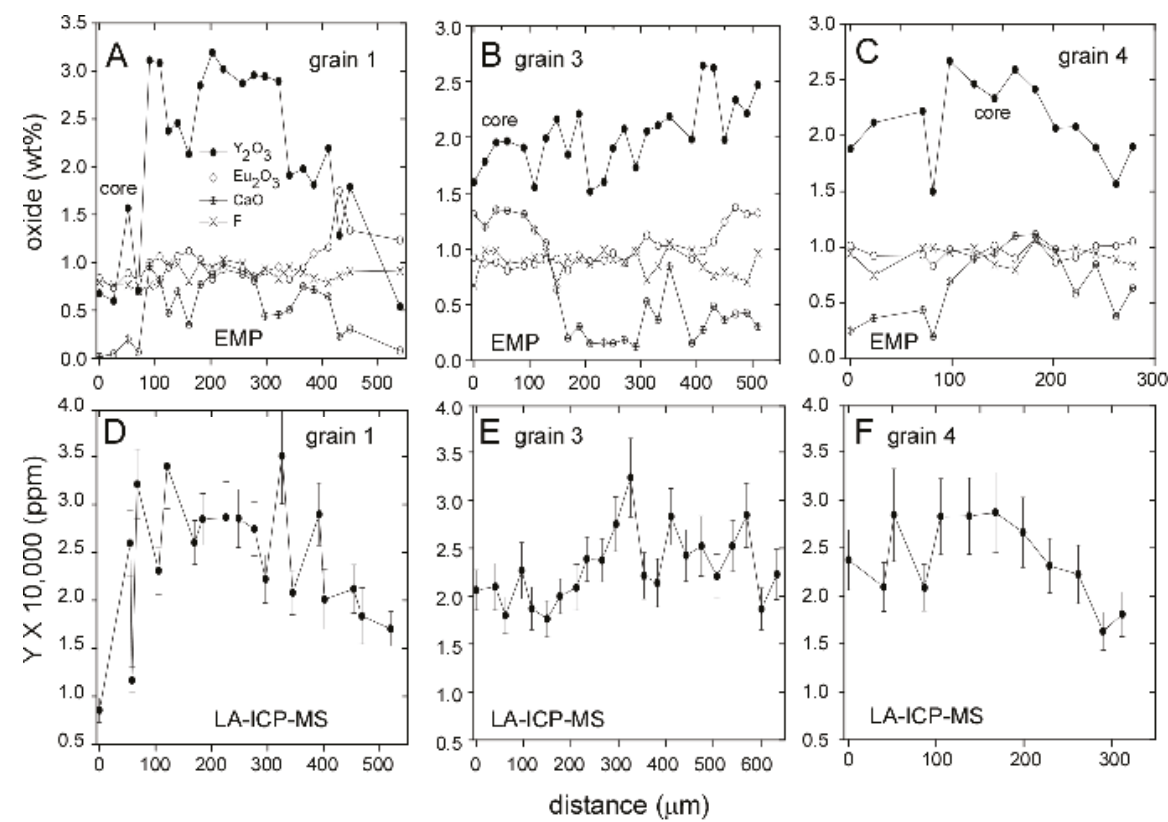

Figure 4. Compositional transects across Llallagua monazite: (A) grain 1; (B) grain 3; and (C) grain 4 in $\mathrm{Y}_{2} \mathrm{O}_{3}, \mathrm{Eu}_{2} \mathrm{O}_{3}, \mathrm{CaO}$ and $\mathrm{F}$ obtained using EPMA. Approximate location of each monazite core is indicated; (D-F) Transects in Y (scale X 10,000 ppm) across Llallagua monazite grain 1, grain 3, and grain 4, respectively, obtained using LA-ICP-MS. See Figure 2 for locations of these transects.

Oscillatory zoning in the Llallagua monazite is seen using high contrast BSE and is controlled by an interplay of high $\mathrm{Z}$ and low $\mathrm{Z}$ elements (Figure 5). Darker regions are dominated by higher amounts of $\mathrm{P}, \mathrm{Si}, \mathrm{Y}$, and $\mathrm{Ca}$, whereas lighter regions contain higher amounts of REE. We found no correlation between a single specific element and brightness of zones within the grains. Although most monazite zoning in BSE is due to the higher atomic masses of Th and $U$, the Llallagua monazite BSE zoning appears controlled by REE contents. If monazite has $\mathrm{REE} / \mathrm{P}+\mathrm{Si}+\mathrm{Y}+\mathrm{Ca}<0.85$, the region appears darker on the BSE image. If it contains $\mathrm{REE} / \mathrm{P}+\mathrm{Si}+\mathrm{Y}+\mathrm{Ca}>0.85$, the area appears brighter.

Using the electron microprobe compositions, the Llallagua monazite has $\mathrm{Ce}_{\mathrm{N}}<\mathrm{La}_{\mathrm{N}}$ and a positive Eu anomaly (Figure 6A-C). Apatite from the Llallagua deposit also shows a positive Eu anomaly that has been linked to crystallization in a reservoir enriched in $\mathrm{Eu}$ [43]. Other monazite grains with positive Eu anomalies and low radiogenic elements have been suggested to be indicative of significant hydrothermal contribution [44]. The amount of $\mathrm{Eu}_{2} \mathrm{O}_{3}(0.99 \pm 0.17 \mathrm{wt} \%$, Table 2, Figure $4 \mathrm{~A}-\mathrm{C})$ is present at levels similar to the amount of $\mathrm{F}$. We see a slight increase in $\mathrm{Eu}_{2} \mathrm{O}_{3}$ from core to rim across the grains, which is not seen in other REEs or $\mathrm{Y}_{2} \mathrm{O}_{3}$ (Figure $4 \mathrm{~A}-\mathrm{C}$ ). 

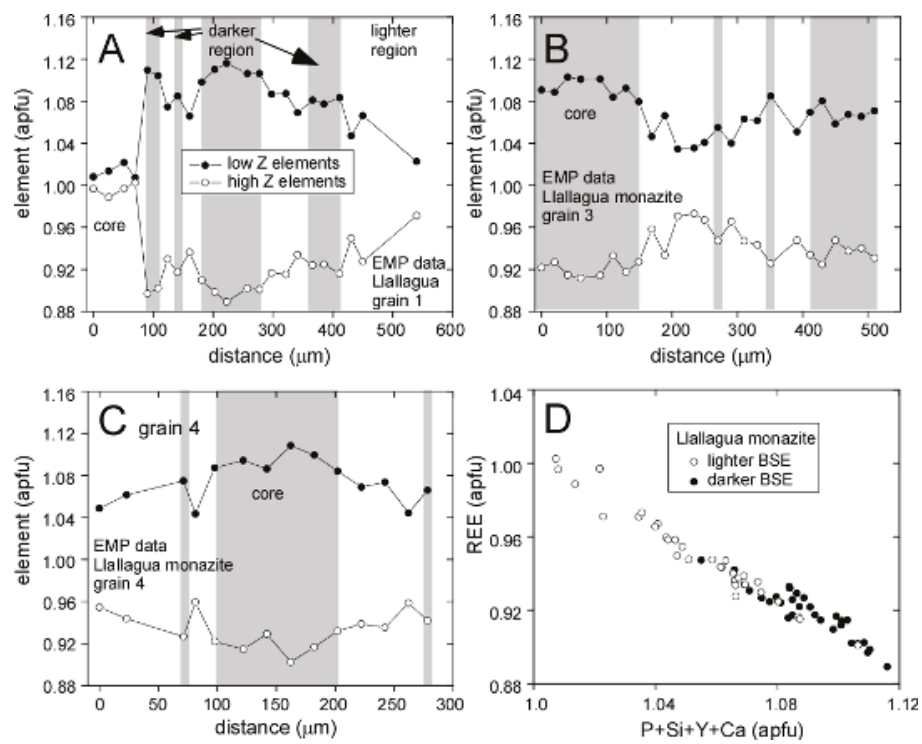

Figure 5. Compositional transects across Llallagua monazite: (A) grain 1; (B) grain 3; and (C) grain 4 in lower atomic number (low Z, black circles) elements ( $\mathrm{P}, \mathrm{Si}, \mathrm{Y}$, and $\mathrm{Ca}$ ) and high atomic number (high Z, open circles) elements ( $\mathrm{La}, \mathrm{Ce}, \mathrm{Pr}, \mathrm{Nd}, \mathrm{Sm}, \mathrm{Eu}, \mathrm{Gd}$, and Tb). Compositions obtained using the EPMA. Shaded areas are approximate regions that appear darker in BSE, whereas white regions are lighter (see Figure 2). Approximate location of each monazite core is indicated; (D) Plot of the low $Z$ versus high $\mathrm{Z}$ elements for all Llallagua monazite EPMA compositions. Black spots correlate to regions that are darker in BSE, whereas open circles appear lighter in BSE.

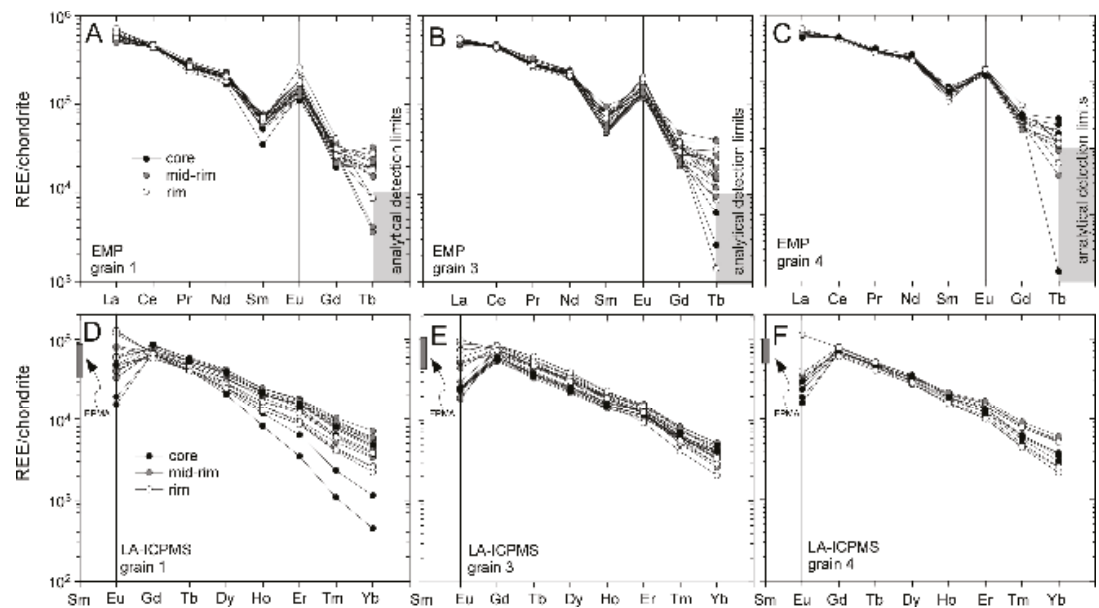

Figure 6. Chondrite-normalized [45] REE plots of Llallagua monazite: (A) grain 1; (B) grain 3; and (C) grain 4 obtained using EPMA. Core regions are indicated by dark circles, mid-rim by grey circles, and rim by white circles. The grey square box indicates approaching instrument detection limits; (D-F) Chondrite-normalized middle and heavy REE patterns obtained using LA-ICP-MS. We include the EPMA analysis of Sm as a grey box. 
No correlation exists between the chondrite-normalized REE patterns or REE contents of the Llallagua monazite and zoning in BSE. We explored numerous trends with REE compositional data and found general relationships between decreasing $\mathrm{Y}$ and increasing $\mathrm{Ce}$, and decreasing La and increasing $\mathrm{Nd}+\operatorname{Pr}$ (Figure 7A,B). This is likely due to ionic radii of these elements, with $\mathrm{Y}$ and heavier REE showing lower affinities for the monazite structure $[46,47]$.
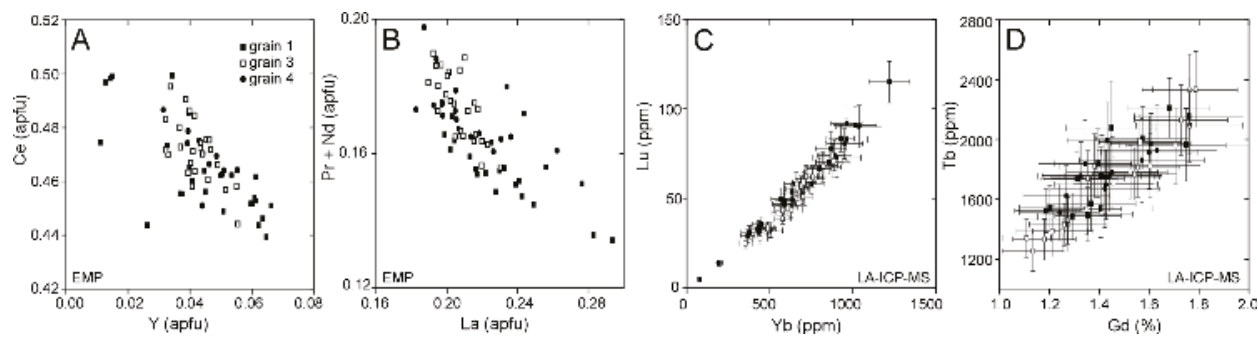

Figure 7. (A) Y (apfu) vs. Ce (apfu); and (B) La (apfu) vs. Pr + Nd (apfu) for individual spots on the Llallagua monazite obtained using EPMA; and (C,D) Yb (ppm) vs. Lu (ppm) and Gd (\%) vs. Tb (ppm), respectively, for individual spots obtained using LA-ICPMS data.

\subsection{Llallagua Monazite LA-ICP-MS Analyses}

Using LA-ICP-MS, we find the Llallagua monazite shows a wide range of concentrations for many minor and trace elements. The grains contain higher amounts of ${ }^{238} \mathrm{U}(123 \pm 17 \mathrm{ppm})$ compared to Th (39 $\pm 20 \mathrm{ppm}$ ) (average of 56 analyses, including uncertainty, $\pm 2 \sigma$; Table 3; Figure $8 \mathrm{~A}-\mathrm{C}$ ), but a few spots do contain higher Th. The highest Th content we measured is located in the core of grain 1 (935 \pm 107 ppm with $85.4 \pm 9.9$ ppm U, see Supplementary Materials, File S1; $\pm 2 \sigma$, Figure $8 \mathrm{~A})$. This is also the brightest region in BSE seen in the monazite (Figure 2). We speculate that the higher \% common $\mathrm{Pb}$ reported for the Llallagua monazite is likely due to the small amounts of radiogenic elements present in the mineral, and thus a lower amount of detectable radiogenic $\mathrm{Pb}$ (average ${ }^{208} \mathrm{~Pb}$ is $0.5 \pm 0.2 \mathrm{ppm}$ ) (see also [11]). Other approaches (Secondary Ion Mass Spectrometry) may be able to detect common $\mathrm{Pb}$, and confirm this hypothesis. Other elements present below detection limits are ${ }^{23} \mathrm{Na},{ }^{27} \mathrm{Al},{ }^{47} \mathrm{Ti},{ }^{55} \mathrm{Mn},{ }^{57} \mathrm{Fe}$, and ${ }^{137} \mathrm{Ba}$. Arsenic-75 is present in the monazite at $195 \pm 23 \mathrm{ppm}$ (average of 56 analyses, including uncertainty, $\pm 2 \sigma$, Table 3 ). This element has been correlated to monazite $\mathrm{S}$ contents [48], but $\mathrm{SO}_{3}$ was not detected using the electron microprobe and not measured using LA-ICP-MS. In addition, the tectonic setting may lend itself to higher amounts of common $\mathrm{Pb}$.

In terms of REE, we find the LA-ICP-MS analyses show $\mathrm{Gd}>\mathrm{Dy}>\mathrm{Eu}>\mathrm{Er}>\mathrm{Tb}>\mathrm{Ho}>\mathrm{Yb}>\mathrm{Tm}$ $>\mathrm{Lu}$ (ppm; Table 3). This differs from the EMP analyses, which yield $\mathrm{Eu}_{2} \mathrm{O}_{3}>\mathrm{Gd}_{2} \mathrm{O}_{3}$ (wt \%). This is likely due to difference in the area sampled during analysis and different detection limits for each approach. The general trends of EPMA and LA-ICP-MS results show overall similar patterns and are consistent with what is expected for the behavior or REE, lending confidence in the LA-ICP-MS results. For example, the amount of $\mathrm{Lu}(\mathrm{ppm})$ increases with increasing amounts of $\mathrm{Yb}(\mathrm{ppm})$ and $\mathrm{Gd}$ (ppm) increases with increasing amounts of $\mathrm{Tb}(\mathrm{ppm})$, a function of the atomic radii of these cations (Figure 7C-D). Transects in $\mathrm{Y}_{2} \mathrm{O}_{3}$ (wt \%) and $\mathrm{Y}(\mathrm{ppm})$ (Figure 4) and $\mathrm{Eu}_{2} \mathrm{O}_{3}$ (wt \%) and Eu (ppm) (Figure 4A-C and Figure 8D-F) show the same general trends. Overall, the amount of Eu (ppm) and U (ppm) increases from core to rim across the grains (Figure 8).

A major difference between the LA-ICP-MS and EPMA is seen with Eu (Figure 6). It is difficult to evaluate the Eu anomaly using LA-ICP-MS data, as we did not measure Sm. If we include Sm data from the EPMA with the LA-ICP-MS HREE data, the results suggests Eu anomaly is negative for core analyses and non-existent to positive at the rim (Figure 6D-F). The approaches do differ in terms of volume of material sampled and thus this trend may not be real. Eu $\mathrm{u}_{\text {measured }} / \mathrm{Eu}_{\text {chondrite }}$ obtained using LA-ICP-MS increases from core or mid-rim to rim for all grains. 
Table 3. Average Llallagua monazite LA-ICP-MS compositions ${ }^{1}$.

\begin{tabular}{ccccc}
\hline Isotope $(\mathbf{p p m})^{\mathbf{2}}$ & ${\text { Grain } \mathbf{1}(\boldsymbol{n}=\mathbf{1 9})^{\mathbf{3}}}$ & Grain $\mathbf{3}(\boldsymbol{n = 2 2 )}$ & Grain $\mathbf{4}(\boldsymbol{n = 1 2 )}$ & All Grains $(\boldsymbol{n}=\mathbf{5 6})$ \\
\hline${ }^{75} \mathrm{As}$ & $173(21)$ & $207(23)$ & $208(27)$ & $195(23)$ \\
${ }^{89} \mathrm{Y}$ & $24,119(3008)$ & $22,946(2596)$ & $23,808(3348)$ & $23,562(2929)$ \\
${ }^{153} \mathrm{Eu}$ & $3459(507)$ & $2429(318)$ & $2078(339)$ & $2719(400)$ \\
${ }^{157} \mathrm{Gd}$ & $14,344(1774)$ & $14,445(1601)$ & $14,291(2012)$ & $14,374(1763)$ \\
${ }^{159} \mathrm{~Tb}$ & $1782(210)$ & $1720(191)$ & $1757(248)$ & $1751(212)$ \\
${ }^{163} \mathrm{Dy}$ & $8165(982)$ & $7635(826)$ & $8058(1082)$ & $7903(945)$ \\
${ }^{165} \mathrm{Ho}$ & $1038(127)$ & $1030(107)$ & $1057(136)$ & $1037(121)$ \\
${ }^{166} \mathrm{Er}$ & $2142(261)$ & $2099(213)$ & $2188(289)$ & $2134(249)$ \\
${ }^{169} \mathrm{Tm}$ & $167(20)$ & $162(16)$ & $169(22)$ & $165(19)$ \\
${ }^{172} \mathrm{Yb}$ & $682(79)$ & $653(65)$ & $686(92)$ & $671(77)$ \\
${ }^{175} \mathrm{Lu}$ & $59(7)$ & $51(5)$ & $55(7)$ & $55(6)$ \\
${ }^{204} \mathrm{~Pb}$ & $5.2(15.6)$ & $1.2(12)$ & $3.0(13)$ & $3.0(14)$ \\
$208 \mathrm{~Pb}$ & $0.5(0.2)$ & $0.6(0.2)$ & $0.3(0.1)$ & $0.5(0.2)$ \\
$232 \mathrm{Th}$ & $103(33)$ & $3.3(1.9)$ & $3.7(1.9)$ & $39(20)$ \\
${ }^{238} \mathrm{U}$ & $160(22)$ & $107(12)$ & $96(13)$ & $123(17)$ \\
\hline
\end{tabular}

${ }^{1}$ Measured but not detected: ${ }^{23} \mathrm{Na},{ }^{27} \mathrm{Al},{ }^{55} \mathrm{Mn},{ }^{57} \mathrm{Fe}$, and ${ }^{137} \mathrm{Ba}$. Supplementary Materials, File $\mathrm{S} 1$ contains details regarding each analysis and standard data; ${ }^{2}$ Compositions reported in $\mathrm{ppm} ;{ }^{3} n=$ number of spots on monazite grain; ${ }^{4}$ Number in parentheses is $2 \sigma$ standard deviation of the average in absolute values, taking into account analytical uncertainties.
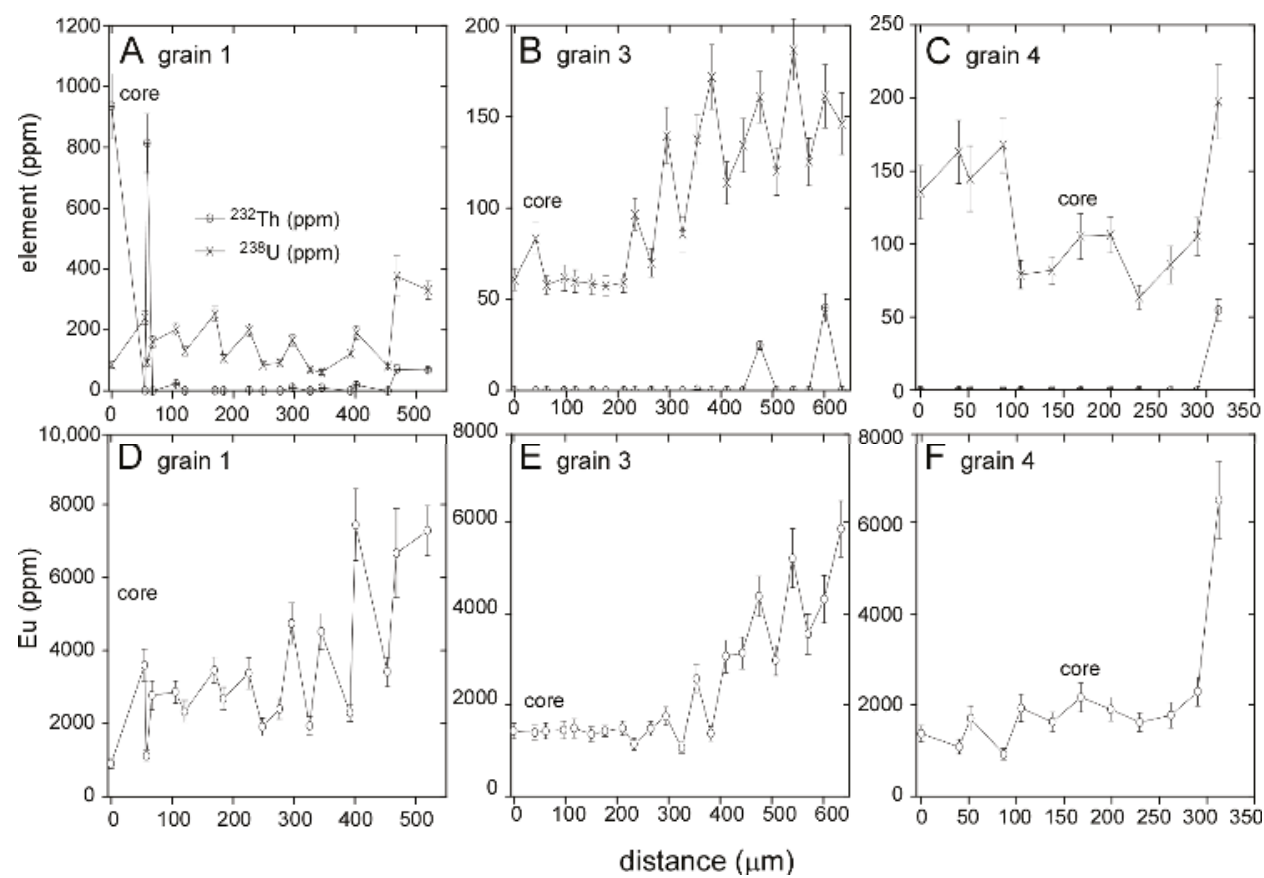

Figure 8. Transects in ${ }^{232} \mathrm{Th}(\mathrm{ppm})$ and ${ }^{238} \mathrm{U}$ (ppm) across Llallagua monazite: (A) grain 1; (B) grain 3; and (C) grain 4. Location of core is indicated; (D-F) Eu (ppm) transects across grains 1, 3, and 4, respectively. Data obtained using LA-ICP-MS. 


\section{Discussion and Conclusions}

\subsection{Evidence for Hydrothermal Origin}

We speculate that the Llallagua monazite precipitated directly from a fluid [15] or via the fluid-mediated replacement of apatite [49]. An alternative origin for these grains is either a primary igneous origin or metamorphism of pre-existing grains. Radiogenic element contents, geochemical signatures, local abundance, and common association with hydrothermal mineral assemblages have been suggested as a means to identify monazite that crystallized from hot, aqueous fluids [50]. We do not have direct field context from these grains, but the role of fluids in the formation of these monazites is supported by field observations by others $[5,6,20]$. Numerous other phosphate minerals have been reported from the deposit, including xenotime, pyromorphite, vanadinite, vivianite, wavelite, vauxite, paravauxite, metavauxite, augelite, childrenite, diadochite, and florencite-Ce $[5,6,15]$. Based on their textural relationships observed by others in hand-sample, most of these phosphates are thought to have formed on the large scale via supergene solutions [15]. Monazite and florencite-Ce appear to be the only major sinks for REE in the Llallagua system [5,6], with radiogenic elements likely hosted primarily by zircon and thorite [6].

In addition, monazite grains with low $\mathrm{U}$ and/or Th are common in rocks that have experienced significant fluid involvement, including authigenic precipitation (e.g., [27,51-53]) or retrograde reactions [54-56]. These types of monazites are also found as hydrothermal precipitates [57-59] or in carbonatites (e.g., [60-63]). We would anticipate higher $\mathrm{ThO}_{2}$ content in igneous monazite (3 to $>5 \mathrm{wt} \% \mathrm{ThO}_{2}$ ) compared to hydrothermal (0-1 wt \% $\mathrm{ThO}_{2}$ ) [50] or authigenic grains (e.g., $0.63 \mathrm{wt} \%$ $\mathrm{ThO}_{2},<0.18 \mathrm{wt} \% \mathrm{UO}_{2}$ ) [52]. Although the bright core in monazite grain 1 (Figure 2A) suggests a different origin from the rest of the grain, its sieve-like texture is commonly observed in monazite that has experienced significant fluid involvement [52]. This core may be the result of secondary alteration, but the oscillatory zoning that parallels its boundaries suggests it may be a primary feature. Oscillatory-zoned monazite is also reported primarily from igneous and/or fluid-rich systems (e.g., $[12,13,64-66])$. In both cases, its composition reflects local feedback between the monazite's growth surface and the fluid supply of elements (e.g., [64]).

\subsection{Insight from Compositional Data}

The Llallagua monazite contains some of the highest amounts of $\mathrm{F}$ reported for the mineral $(0.88 \pm 0.10 \mathrm{wt} \% \mathrm{~F}$, Table 2, Figure 4A-C). Fluorine is an unusual element to be found in monazite, with higher amounts being reported in grains affected by secondary fluid-mediated alteration $(0.3-0.6 \mathrm{wt} \%)$ [67] as well as those found in rare metal ore deposits $(0.48 \pm 0.07 \mathrm{wt} \%)$ [68]. Fluorine is used to charge balance the huttonite substitution [69] and is thought to play a factor in the enrichment of high-Th monazites [70]. Fluorine-rich fluids are an effective medium for transporting $\mathrm{Y}$ and REE in a variety of geologic environments $[67,68,71-73]$, and appear to have no effect on monazite stability [74]. These types of fluids appear to enhance the mobility of Th compared to $\mathrm{U}$ and contribute common $\mathrm{Pb}$ to monazite [75]. The Llallagua grains show both higher $\mathrm{U} / \mathrm{Th}$ ratios and common ${ }^{206} \mathrm{~Pb}$, consistent with this observation. We find $\mathrm{F}$ does not vary in concentration from core to rim across the grains (Figure 4A-C).

Fluorapatite is common in the Llallagua mine $[5,6,15]$, and some have speculated that the presence of $\mathrm{F}$ in the Llallagua monazite may be due in part of the decomposition of fluorapatite during the final stages of hydrothermal deposition $[6,66,76]$. Phosphates suggested to form during the dissolution of apatite include wavellite, paravauxite, and childrenite [6]. This process wherein apatite plays a role in the formation of monazite is commonly observed in ore deposits world-wide and can yield monazite with distinctly low amounts of radiogenic elements and higher $\mathrm{U} / \mathrm{Th}$, as is observed in these samples [77-82]. Alternatively, the presence of $\mathrm{F}$ in monazite may be due to early stage crystallization in the presence of F-rich fluids. In the grains we analyzed, we do not see evidence for the direct replacement of apatite in the monazite textures or zoning. 
Monazite BSE zoning is controlled by an interplay of high atomic number ( $\mathrm{Z}, \mathrm{REE})$ and low $\mathrm{Z}$ $(\mathrm{Si}+\mathrm{Ca}+\mathrm{P}+\mathrm{Y})$ elements (Figure 5) and cannot be attributed to a single control. The bright core of monazite grain 1 (Figure $2 \mathrm{~A}$ ) has low $\mathrm{CaO}(0.2-0.4 \mathrm{wt} \%)$, which would not be expected if the grain directly replaced existing apatite. The darker cores in grains 3 and 4 have $1.30-1.05 \mathrm{wt} \% \mathrm{CaO}$ and are surrounded by oscillatory zoning (Figure $2 \mathrm{~B}, \mathrm{C}$ ), suggesting precipitation from a fluid containing in this phase. Monazite and apatite in the Llallagua deposit share substitution mechanisms, including $\mathrm{Ca}_{3} \mathrm{REE}_{-2}$, CaPREE-1 $\mathrm{Si}_{-1}$, and CaSiREE -2 (Figure 3). Their $\mathrm{SiO}_{2}(0.17 \pm 0.03 \mathrm{wt} \%)$ and REE contents may also have been derived from apatite, which is seen in other settings (e.g., [77-79,83]). An Eocene Sm-Nd apatite age [24] is $\sim 20$ m.y. older than the monazite [7,11], lending support for the hypothesis of monazite precipitation via the dissolution of pre-existing apatite. Apatite and monazite have been shown to yield similar ages in metamorphic and igneous rocks with any age discrepancies associated with fluid-induced retrogression [84].

Apatite and monazite from the Llallagua deposit share positive Eu anomalies seen in the EPMA data set (Figure 6) [43]. If plagioclase was present in the system during a phase of apatite crystallization, the mineral would likely not show this characteristic [85]. Rare plagioclase phenocrysts are found in the volcanic porphyry, but are often replaced by tourmaline, sercite, quartz, kaolinite, cassiterite or pyrite $[6,86]$. The LA-ICP-MS data are difficult to evaluate due to the lack of the Sm measurement, but the electron microprobe results suggest the grains record a positive Eu anomaly. Monazite with positive Eu anomalies has been reported from banded iron formations [44], carbonatites [87], lower crustal rocks [88,89], and in metamorphic rocks as inclusions in plagioclase [90]. Fluids with strongly positive Eu anomalies are characteristic of highly reducing conditions [91-94], including back arc basin settings like the Llallagua deposit [95].

Both the EPMA and LA-ICP-MS analyses show the amount of Eu overall in the Llallagua monazite increases from core to rim (Figures 4 and 8), suggesting the mineral sequestered this element from the fluids in which it crystallized. The Eu contents of the monazite grains are high $\left(0.99 \pm 0.17 \mathrm{wt} \% \mathrm{Eu}_{2} \mathrm{O}_{3}\right.$, $2719 \pm 400 \mathrm{ppm}$ Eu; Tables 2 and 3) compared to those from metamorphic settings (<0.5 wt \%) [90].

Overall, the monazite compositions reported here can constrain elements of the fluid chemistry, assist with tectonic interpretations, and suggest mineral reactions. We do not have key field or mineralogical contexts for the grains collected, and our comments regarding its tectonic setting should therefore be interpreted with caution. Despite this, the monazite chemistry reported here provides some clues that are useful for interpreting its origin and the origin of others like it. The results are consistent with the Llallagua monazite forming in a highly reducing environment via the direct precipitation of F- and Eu-rich hydrothermal fluids. These elements may have been supplied by the dissolution of flourapatite that formed during an earlier tectonic episode. The positive Eu anomalies seen in the grains lend support for reducing conditions.

Monazite is an important REE ore [96-99]. Numerous technological devices are reliant on REE components and demand for these elements is projected to increase [99-101]. Identifying and characterizing known and potential REE sources are important issues facing the public and policy makers [101,102]. Most monazite ore deposits that are economically viable rare earth resources are placer [97,101,103], with rare primary deposits, which include the Van Rhynsdorp and Naboomspruit in South Africa [104], Front Range in Colorado [105], Mountain Pass in California [106], and Bayan Obo in China [107]. Comparisons of our compositional data with those from major monazite ore localities indicate the grains share characteristics $\left(20-30 \% \mathrm{Ce}_{2} \mathrm{O}_{3} ; 10 \%\right.$ to $40 \% \mathrm{La}_{2} \mathrm{O}_{3}$, significant amounts of $\mathrm{Nd}$, $\mathrm{Pr}$, and Sm, lesser amounts of Dy, Er, and Ho) [97]. A major environmental concern with the extraction of REEs from monazite is the presence of radiogenic elements [103,108-111]. Compositional analyses and attempts to date the Llallagua monazite have consistently reported its minor $\mathrm{U}$ and Th contents (this study, $[5,7,11,15,20])$. The low radiogenic element content of the Llallagua monazite may help minimize issues associated with waste management.

Supplementary Materials: The following are available online at http://www.mdpi.com/2079-9276/6/3/36/s1, Excel file of EPMA and LA-ICP-MS analyses of the monazite grains. 
Acknowledgments: Source of funding for the study was the UT Austin Jackson School of Geosciences Advisory Council Centennial Teaching Fellowship, which was also used to cover costs to publish with open access. We thank Alfredo Petrov (mindat.org) for supplying the monazite grains analyzed in this study and Isis Garber for analytical assistance. We appreciate analytical assistance and discussions with George Morgan at the University of Oklahoma Electron Microprobe Laboratory. We appreciate editorial handling by Ms. Renee Li, and reviews of the manuscript from Dan Harlov, Gleb Pokrovski, and three anonymous reviewers. We also appreciate assistance from the Jackson School of Geosciences' Writer-In-Residence, Adam Papendieck.

Author Contributions: E.J.C. conceived and designed the experiments; N.R.M. performed the experiments; E.C. and N.M. analyzed the data; and E.C. wrote the paper.

Conflicts of Interest: The authors declare no conflict of interest. The founding sponsors had no role in the design of the study; in the collection, analyses, or interpretation of data; in the writing of the manuscript, and in the decision to publish the results.

\section{References}

1. Ahlfeld, F. Zoning in the Bolivian Tin Belt. Econ. Geol. Bull. Soc. Econ. Geol. 1941, 36, 569-588. [CrossRef]

2. Mlynarczyk, M.J.; Williams-Jones, A.E. The role of collisional tectonics in the metallogeny of the Central Andean tin belt. Earth Planet. Sci. Lett. 2005, 240, 656-667. [CrossRef]

3. Ahfeld, F.; Schneider-Scherbina, A. Los Yacimientos Minerales y de Hidrocarburos de Bolivia; Ministry of Mines and Petroleum: La Paz, Bolivia, 1964; p. 388.

4. Sillitoe, R.H.; Halls, C.C.; Grant, J.N. Porphyry tin deposits in Bolivia. Econ. Geol. Bull. Soc. Econ. Geol. 1975, 70, 913-927. [CrossRef]

5. Bandy, M.C. Mineralogy of Llallagua, Bolivia. Tucson Gem and Mineral Society: Tucson, AZ, USA, 1976; p. 67.

6. Hyrsl, J.; Petrov, A. Llallagua, Bolivia. Miner. Rec. 2006, 37, 117-162.

7. Kempe, U.; Lehmann, B.; Wolf, D.; Rodionov, N.; Bombach, K.; Schwengfelder, U.; Dietrich, A. U/Pb SHRIMP geochronology of Th-poor, hydrothermal monazite: an example from the Llallagua tin porphyry deposit, Bolivia. Geochem. Cosmochim. Acta 2008, 72, 4352-4366. [CrossRef]

8. Ahlfeld, F. The tin ores of Uncia-Llallagua, Bolivia. Econ. Geol. Bull. Soc. Econ. Geol. 1931, 26, 241-257. [CrossRef]

9. Turneaure, F.S. The tin deposits of Llallagua, Bolivia. Econ. Geol. Bull. Soc. Econ. Geol. 1935, 30, 14-60. [CrossRef]

10. Turneaure, F.S. A comparative study of major ore deposits of central Bolivia. Econ. Geol. Bull. Soc. Econ. Geol. 1960, 55, 217-254. [CrossRef]

11. Kohn, M.J.; Vervoort, J.D. U-Th-Pb dating of monazite by single-collector ICP-MS: Pitfalls and potential. Geochem. Geophys. Geosys. 2008, 9, Q04031. [CrossRef]

12. Hawkins, D.P.; Bowring, S.A. U-Pb systematics of monazite and xenotime: Case studies from the Paleoproterozoic of the Grand Canyon, Arizona. Contrib. Miner. Pet. 1997, 127, 87-103. [CrossRef]

13. Crowley, J.L.; Brown, R.L.; Gervais, F.; Gibson, H.D. Assessing inheritance of zircon and monazite in granitic rocks from the Monashee complex Canadian cordillera. J. Pet. 2008, 49, 1915-1929. [CrossRef]

14. Catlos, E.J. Generalizations about monazite: Implications for geochronologic studies. Am. Mineral. 2013, 98, 819-832. [CrossRef]

15. Gordon, S.G. The mineralogy of the tin mines of Cerro de Llallagua, Bolivia. Proc. Acad. Nat. Sci. Phila. 1944, 96, 279-359.

16. Long, K.; Ludington, S.; du Bray, E.; Andre-Ramos, O.; McKee, E.H. Geology and mineral deposits of the La Joya District, Bolivia. Soc. Econ. Geol. News 1992, 10, 13-16.

17. Grant, J.N.; Halls, C.C.; Avila Salinas, W.W.; Snelling, N.J. K-Ar ages of igneous rocks and mineralization in part of the Bolivian tin belt. Econ. Geol. Bull. Soc. Econ. Geol. 1979, 74, 838-851. [CrossRef]

18. Lehmann, B. Petrochemical factors governing the metallogeny of the Bolivian tin belt. In Tectonics of the Southern Central Andes, Structure and Evolution of an Active Continental Margin; Reutter, K.J., Scheuber, E., Wigger, P., Eds.; Springe: Berlin, Germany, 1994; pp. 317-326.

19. Jimenez, N.; Lopez Velasquez, S. Magmatism in the Huarina Belt, Bolivia, and its geotectonic implications. Tectonophys 2008, 459, 85-106. [CrossRef] 
20. Gordon, S.G. Thorium-free monazite from Llallagua, Bolivia. In Academy of Natural Sciences, Philadelphia, Notulae Naturae; The Academy of Natural Sciences: Philadelphia, PA, USA, 1939; Volume 2, pp. 1-7.

21. Corfu, F. Differential response of U-Pb systems in coexisting accessory minerals, Winnipeg River Subprovince, Canadian Shield: Implications for Archean crustal growth and stabilization. Contrib. Miner. Pet. 1988, 98, 312-325. [CrossRef]

22. Parrish, R.R. U-Pb dating of monazite and its application to geological problems. Can. J. Earth Sci. 1990, 27, 1431-1450. [CrossRef]

23. Seydoux-Guillaume, A.; Paquette, J.; Wiedenbeck, M.; Montel, J.; Heinrich, W. Experimental resetting of the U-Th-Pb systems in monazite. Chem. Geol. 2002, 191, 165-181. [CrossRef]

24. Rakovan, J.; McDaniel, D.K.; Reeder, R.J. Use of surface-controlled REE sectoral zoning in apatite from Llallagua, Bolivia, to determine a single-crystal Sm-Nd age. Earth Planet. Sci. Lett. 1997, 146, 329-336. [CrossRef]

25. Wolf, D.; Schwengfelder, U.; Bombach, K.; Kempe, U.; Lehmann, B.; Dietrich, A. Pb/Pb single zircon evaporation dating at the Sn porphyry of Llallagua, Bolivia. Terra Nostra 2003, 2, 87.

26. Dominy, S.C.; Annels, A.E.; Camm, G.; Wheeler, P.; Barr, S. Geology in the resource and reserve estimation of narrow vein deposits. Explor. Min. Geol. 1997, 6, 317-333.

27. Dominy, S.C.; Camm, G.S. Tin mineralization in south-west England: Nature of veins and controls on ore localization. Proc. Ussher Soc. 1997, 9, 19.

28. Catlos, E.J.; Miller, N.R. Ion microprobe ${ }^{208} \mathrm{Th}-{ }^{208} \mathrm{~Pb}$ ages from high common $\mathrm{Pb}$ monazite, Morefield Mine, Amelia County, Virginia: Implications for Alleghanian tectonics. Am. J. Sci. 2016, 316, 470-503. [CrossRef]

29. Montel, J.; Foret, S.; Veschambre, M.; Nicollet, C.; Provost, A. Electron microprobe dating of monazite. Chem. Geol. 1996, 131, 37-53. [CrossRef]

30. Hetherington, C.J.; Jercinovic, M.J.; Williams, M.L.; Mahan, K. Understanding geologic processes with xenotime: Composition, chronology, and a protocol for electron probe microanalysis. Chem. Geol. 2008, 254, 133-147. [CrossRef]

31. Young, E.; Myers, A.; Munson, E.; Conklin, N. Mineralogy and geochemistry of fluorapatite from Cerro de Mercado, Durango, Mexico. US Geol. Surv. Prof. Pap. 1969, 650, D84-D93.

32. Longerich, H.P.; Jackson, S.E.; Günther, D. Laser ablation inductively coupled plasma mass spectrometric transient signal data acquisition and analyte concentration calculation. J. Anal. Atom. Spectr. 1996, 11, 899-904. [CrossRef]

33. Jochum, K.P.; Weis, U.; Stoll, B.; Kuzmin, D.; Yang, Q.; Raczek, I.; Jacob, D.E.; Stacke, A.; Birbaum, K.; Frick, D.A.; Gunther, D.; Enzweiler, J. Determination of reference values for NIST SRM 610—617 glasses following ISO guidelines. Geostand. Geoanal. Res. 2011, 35, 397-429. [CrossRef]

34. D'Oriano, C.; Da Pelo, S.; Podda, F.; Cioni, R. Laser-ablation inductively coupled plasma mass spectrometry (LA-ICP-MS): Setting operating conditions and instrumental performance. Period. Di Miner. 2008, 77, 65-74.

35. Xu, P.; Guan, H.; Sun, M.; Malps, J. Methodology of trace element in situ analyses using laser ablation inductively coupled plasma mass spectrometry. Yanshi Xuebao Acta Petrol. Sin. 2000, 16, 291-304.

36. Hellstrom, J.C.; Paton, C.; Woodhead, J.D.; Hergt, J. Iolite: Software for spatially resolved LA-(quad and MC) ICPMS analysis. Miner. Soc. Can. Short Course 2008, 40, 343-348.

37. Jochum, K.P.; Stoll, B.; Weis, U.; Jacob, D.E.; Mertz Kraus, R.; Andreae, M.O. Non-matrix-matched calibration for the multi-element analysis of geological and environmental samples using $200 \mathrm{~nm}$ Femtosecond LA-ICP-MS: A comparison with nanosecond lasers. Geostand. Geoanal. Res. 2014, 38, 265-292. [CrossRef]

38. Della Ventura, G.; Mottana, A.; Parodi, G.C.; Raudsepp, M.; Bellatreccia, F.; Caprilli, E.; Rossi, P.; Fiori, S. Monazite-huttonite solid-solutions from the Vico volcanic complex, Latium, Italy. Mineral. Mag. 1996, 60, 751-758. [CrossRef]

39. Ronsbo, J.G. Coupled substitutions involving REEs and Na and Si in apatites in alkaline rocks from the Ilimaussaq intrusion, South Greenland, and the petrologic implications. Am. Mineral. 1989, 74, 896-901.

40. Stormer, J.C.; Carmichael, I.E. Fluorine-hydroxyl exchange in apatite and biotite: A potential igneous geothermometer. Contrib. Miner. Petrol. 1971, 31, 121-131. [CrossRef]

41. Smith, M.P.; Yardley, B.W.D. Fluid evolution during metamorphism of the Otago schist, New Zealand: (II) Influence of detrital apatite on fluid salinity. J. Metamorph. Geol. 1999, 17, 187-193. [CrossRef]

42. Pyle, J.M.; Spear, F.S.; Wark, D.A. Electron microprobe analysis of REE in apatite, monazite and xenotime: Protocols and pitfalls. Rev. Miner. Geochem. 2002, 48, 337-362. [CrossRef] 
43. Roeder, P.L.; MacArthur, D.; Ma, X.; Palmer, G.R.; Mariano, A.N. Cathodoluminescence and microprobe study of rare-earth elements in apatite. Am. Mineral. 1987, 72, 801-811.

44. Bowins, R.J.; Crocket, J.H. Monazite, xenotime and REE minerals in Archean banded iron-formation from the Sherman and Adams mines, Ontario, Canada. Can. Mineral. 2011, 49, 749-763. [CrossRef]

45. Sun, S.-S.; McDonough, W.F. Chemical and isotopic systematic of ocean basalts: Implications for mantle composition and processes. Geol. Soc. Lond. Special Pub. 1989, 42, 313-345. [CrossRef]

46. Mohr, D.W. Zoned porphyroblasts of metamorphic monazite in the Anakeesta Formation, Great Smoky Mountains, North Carolina. Am. Mineral. 1984, 69, 98-103.

47. Spear, F.S.; Pyle, J.M. Apatite, monazite, and xenotime in metamorphic rocks. Rev. Miner. Geochem. 2002, 48, 293-335. [CrossRef]

48. Uher, P.; Ondrejka, M.; Broska, I. S and As in accessory monazite: A role of "clinoanhydrite" and gasparite substitution. In Proceedings of the European Geosciences Union, Research Abstracts, Vienna, Austria, 15-20 April 2007; Volume 9, p. 09146.

49. Betkowski, W.B.; Harlov, D.E.; Rakovan, J. Hydrothermal mineral replacement reactions for an apatite-monazite assemblage in alkali-rich fluids. In Proceedings of the Goldschmidt Conference, Sacramento, CA, USA, 8-13 June 2014; p. 193.

50. Schandl, E.S.; Gorton, M. A textural and geochemical guide to the identification of hydrothermal monazite: Criteria for selection of samples for dating epigenetic hydrothermal ore deposits. Econ. Geol. Bull. Soc. Econ. Geol. 2004, 99, 1027-1035. [CrossRef]

51. Cabella, R.; Lucchetti, G.; Marescotti, P. Authigenic monazite and xenotime from pelitic metacherts in pumpellyite-actinolite-facies conditions, Sestri-Voltaggio zone, central Liguria, Italy. Can. Mineral. 2001, 39, 717-727. [CrossRef]

52. Čopjaková, R.; Novak, M.; Francu, E. Formation of authigenic monazite-(Ce) to monazite-(Nd) from upper carboniferous graywackes of the drahany upland: Roles of the chemical composition of host rock and burial temperature. Lithos 2011, 127, 373-385. [CrossRef]

53. Alipour-Asll, M.M.; Mirnejad, H.H.; Milodowski, A.E. Occurrence and paragenesis of diagenetic monazite in the Upper Triassic black shales of the Marvast region, South Yazd, Iran. Miner. Petrol. 2012, 104, 197-210. [CrossRef]

54. Dahl, P.S.; Terry, M.P.; Jercinovic, M.J.; Williams, M.L.; Hamilton, M.A.; Foland, K.A.; Clement, S.M.; Friberg, L.M. Electron probe (Ultrachron) microchronometry of metamorphic monazite: Unraveling the timing of polyphase thermotectonism in the easternmost Wyoming Craton (Black Hills, South Dakota). Am. Mineral. 2005, 90, 1712-1728. [CrossRef]

55. Gasser, D.; Bruand, E.; Rubatto, D.; Stuewe, K. The behaviour of monazite from greenschist facies phyllites to anatectic gneisses: An example from the Chugach metamorphic complex, southern Alaska. Lithos 2012, 134-135, 108-122. [CrossRef] [PubMed]

56. Rasmussen, B.; Muhling, J.R. Reactions destroying detrital monazite in greenschist facies sandstones from the Witwatersrand Basin, South Africa. Chem. Geol. 2009, 264, 311-327. [CrossRef]

57. Torab, F.M.; Lehmann, B.B. Magnetite-apatite deposits of the Bafq district, central Iran: Apatite geochemistry and monazite geochronology. Mineral. Mag. 2007, 71, 347-363. [CrossRef]

58. Mercadier, J.; Skirrow, R.G.; Cross, A.J. Uranium and gold deposits in the Pine Creek Orogen (North Australian Craton): a link at 1.8 Ga? Precamb. Res. 2013, 238, 111-119. [CrossRef]

59. Pandey, M.; Pant, N.C.; Kumar, S. Criteria to distinguish between regional and contact zone monazite: A case study from Proterozoic north Delhi fold belt (NDFB), India. Episodes 2013, 36, 275-289.

60. Wall, F.; Mariano, A.N. Rare earth minerals in carbonatites: A discussion centered on the Kangankunde Carbonatite, Malawi. In Rare Earth Minerals: Chemistry, Origin and ore Deposits; Jones, A.P., Wall, F., Williams, T.C., Eds.; Chapman and Hall, Mineralogical Society Series: London, UK, 1996; pp. 193-225.

61. Cressey, G.G.; Wall, F.; Cressey, B.A. Differential REE uptake by sector growth of monazite. Mineral. Mag. 1999, 63, 813-828. [CrossRef]

62. Pilipiuk, A.N.; Ivanikov, V.V.; Bulakh, A.G. Unusual rocks and mineralisation in a new carbonatite complex at Kandaguba, Kola Peninsula, Russia. Lithos 2001, 56, 333-347. [CrossRef]

63. Catlos, E.J.; Dubey, C.S. Sivasubramanian, Monazite ages from carbonatites and high-grade assemblages along the Kambam Fault Southern Granulite Terrain, South India. Am. Mineral. 2008, 93, 1230-1244. [CrossRef] 
64. Shore, M.; Fowler, A.D. Oscillatory zoning in minerals: A common phenomenon. Can. Mineral. 1996, 34, 1111-1126.

65. Schaltegger, U.; Fanning, C.M.; Günther, D.; Maurin, J.C.; Schulmann, K.; Gebauer, D. Growth, annealing and recrystallization of zircon and preservation of monazite in high-grade metamorphism: Conventional and in situ U-Pb isotope, cathodoluminescence and microchemical evidence. Contrib. Mineral. Petrol. 1999, 134, 186-201. [CrossRef]

66. Couëslan, C.G.; Pattison, D.M.; Dufrane, S. Paleoproterozoic metamorphic and deformation history of the Thompson nickel belt, Superior boundary zone, Canada, from in situ U-Pb analysis of monazite. Precamb. Res. 2013, 237, 13-35. [CrossRef]

67. Hetherington, C.J.; Harlov, D.E. Metasomatic thorite and uraninite inclusions in xenotime and monazite from granitic pegmatites, Hidra anorthosite massif, southwestern Norway: Mechanics and fluid chemistry. Am. Mineral. 2008, 93, 806-820. [CrossRef]

68. Sheard, E.R.; Williams-Jones, A.E.; Heiligmann, M.; Pederson, C.; Trueman, D.L. Controls on the concentration of zirconium, niobium, and the rare earth elements in the Thor Lake rare metal deposit, Northwest Territories, Canada. Econ. Geol. Bull. Soc. Econ. Geol. 2012, 107, 81-104. [CrossRef]

69. Kucha, H. Continuity in the monazite-huttonite series. Mineral. Mag. 1980, 43, 1031-1034. [CrossRef]

70. Watt, G.R. High-thorium monazite-(Ce) formed during disequilibrium melting of metapelites under granulite-facies conditions. Mineral. Mag. 1995, 59, 735-743. [CrossRef]

71. Keppler, H. Influence of fluorine on the enrichment of high field strength trace elements in granitic rocks. Contrib. Mineral. Petrol. 1993, 114, 479-488. [CrossRef]

72. Papoutsa, A.D.; Pe-Piper, G. The relationship between REE-Y-Nb-Th minerals and the evolution of an A-type granite, Wentworth Pluton, Nova Scotia. Am. Mineral. 2013, 98, 444-462. [CrossRef]

73. Tropper, P.P.; Harlov, D.E.; Manning, C.E. Ce-monazite and Y-xenotime solubilities in $\mathrm{H}_{2} \mathrm{O}-\mathrm{NaF}$ at $800{ }^{\circ} \mathrm{C}$, 1 GPa: Implications for REE transport. Mineral. Mag. 2013, 77, 2358.

74. Duc-Tin, Q.; Keppler, H. Monazite and xenotime solubility in granitic melts and the origin of the lanthanide tetrad effect. Contrib. Mineral. Petrol. 2015, 169. [CrossRef]

75. Didier, A.A.; Bosse, V.V.; Boulvais, P.P.; Bouloton, J.J.; Paquette, J.L.; Montel, J.M.; Devidal, J.L. Disturbance versus preservation of $\mathrm{U}-\mathrm{Th}-\mathrm{Pb}$ ages in monazite during fluid-rock interaction: Textural, chemical and isotopic in situ study in microgranites (Velay Dome, France). Contrib. Mineral. Petrol. 2013, 165, 1051-1072. [CrossRef]

76. Harlov, D.E.; Förster, H. Fluid-induced nucleation of (Y+REE)-phosphate minerals within apatite: Nature and experiment. Part II, Fluorapatite. Am. Mineral. 2003, 88, 1209-1229. [CrossRef]

77. Pan, Y.Y.; Fleet, M.E.; MacRae, N.D. Oriented monazite inclusions in apatite porphyroblasts from the Hemlo gold deposit, Ontario, Canada. Mineral. Mag. 1993, 57, 697-707. [CrossRef]

78. Harlov, D.E.; Förster, H. High-grade fluid metasomatism on both a local and a regional scale: The Seward Peninsula, Alaska, and the Val Strona di Omegna, Ivrea-Verbano Zone, Northern Italy. Part II: Phosphate mineral chemistry. J. Petrol. 2002, 43, 801-824. [CrossRef]

79. Harlov, D.E.; Andersson, U.B.; Förster, H.; Nystrom, J.; Dulski, P.; Broman, C. Apatite-monazite relations in the Kiirunavaara magnetite-apatite ore, northern Sweden. Chem. Geol. 2002, 191, 47-72. [CrossRef]

80. Ziemann, M.A.; Förster, H.; Harlov, D.E.; Frei, D. Origin of fluorapatite-monazite assemblages in a metamorphosed, sillimanite-bearing pegmatoid, Reinbolt Hills, East Antarctica. Eur. J. Miner. 2005, 17, 567-579. [CrossRef]

81. Finger, F.F.; Krenn, E.E. Three metamorphic monazite generations in a high-pressure rock from the Bohemian Massif and the potentially important role of apatite in stimulating polyphase monazite growth along a PT loop. Lithos 2007, 95, 103-115. [CrossRef]

82. Bonyadi, Z.; Davidson, G.J.; Mehrabi, B.; Meffre, S.; Ghazban, F. Significance of apatite REE depletion and monazite inclusions in the brecciated Se-Chahun iron oxide-apatite deposit, Bafq district, Iran: Insights from paragenesis and geochemistry. Chem. Geol. 2011, 281, 253-269. [CrossRef]

83. Ayres, M.; Harris, N. REE fractionation and Nd-isotope disequilibrium during crustal anatexis: Constraints from Himalayan leucogranites. Chem. Geol. 1997, 139, 249-269. [CrossRef]

84. Berger, M.; Braun, I. Pb-Pb dating of apatite by a stepwise dissolution technique. Chem. Geol. 1997, 142, 23-40. [CrossRef] 
85. Cawthorn, R.G. Rare earth element abundances in apatite in the Bushveld Complex: A consequence of the trapped liquid shift effect. Geology 2013, 41, 603-606. [CrossRef]

86. Hyrsl, J.; Petrov, A. Pseudomorphs from Bolivia a review. Rocks Miner. 1998, 73, 410-414. [CrossRef]

87. Kim, S.; Lee, H.; Yin, J.; Park, J. Chemistry and origin of monazites from carbonatite dikes in the Hongcheon-Jaeun district, Korea. J. Asian Earth Sci. 2005, 25, 57-67. [CrossRef]

88. Dumond, G.; Williams, M.; Goncalves, P.; Jercinovic, M. Monazite as a monitor of melting, garnet growth, and feldspar recrystallization in continental lower crust: Athabasca granulite terrane, western Canadian Shield. In Proceedings of the Geological Society of America Annual Meeting, Houston, TX, USA, 5 October 2008; p. 206.

89. Goncalves, P.; Trap, P.; Dumond, G.; Marquer, D.; Feybesse, J.; Paquette, J. Monazite as a monitor of melting in continental crust. In Proceedings of the Geological Society of America Annual Meeting, Minneapolis, MN, 9-12 October 2011; p. 330.

90. Zhu, X.K.; O'Nions, R.K. Monazite chemical composition: Some implications for monazite geochronology. Contrib. Miner. Petrol. 1999, 137, 351-363. [CrossRef]

91. Moeller, E. Eu anomalies in hydrothermal minerals: Kinetic versus thermodynamic interpretation. In Proceedings of the Ninth Quadrennial IAGOD Symposium, Beijing, China, 12-18 August 1994; Schweizerbart science publishers: Stuttgart, Germany, 1998; Volume 9, pp. 239-246.

92. Wood, S.A. The geochemistry of rare earth elements and yttrium in geothermal waters. Special Pub. Soc. Econ. Geol. 2003, 10, 133-158.

93. Bao, S.; Zhou, H.; Peng, X.; Ji, F.; Yao, H. Geochemistry of REE and yttrium in hydrothermal fluids from the Endeavour segment, Juan de Fuca Ridge. Geochem. J. 2008, 42, 359-370. [CrossRef]

94. Schmidt, K.K.; Garbe-Schonberg, D.D.; Bau, M.M.; Koschinsky, A.A. Rare earth element distribution in $>400$ degrees $\mathrm{C}$ hot hydrothermal fluids from 5 degrees S, MAR: The role of anhydrite in controlling highly variable distribution patterns. Geochim. Cosmochim. Acta 2010, 74, 4058-4077. [CrossRef]

95. Douville, E.; Charlou, J.L.; Oelkers, E.H.; Bienvenu, P.P.; Jove Colon, C.F.; Donval, J.P.; Fouquet, Y.; Prieur, D.; Appriou, P. The Rainbow Vent fluids $\left(36^{\circ} 14^{\prime} \mathrm{N}, \mathrm{MAR}\right)$ : The influence of ultramafic rocks and phase separation on trace metal content in Mid-Atlantic Ridge hydrothermal fluids. Chem. Geol. 2002, 184, 37-48. [CrossRef]

96. $\mathrm{Xu}, \mathrm{Y}$. Magnetically recoverable rare-metal-rich rutile and monazite in ore and tailings of the Climax and Henderson molybdenum mines. Master's Thesis, Purdue University, West Lafayette, IN, USA, 1992.

97. Gupta, C.K.; Krishnamurthy, N. Extractive Metallurgy of Rare Earths; CRC Press: Boca Raton, FL, USA, 2004; p. 504.

98. Long, K.R.; Van Gosen, B.S.; Foley, N.K.; Cordier, D. The Principal Rare Earth Elements Deposits of the United States-A Summary of Domestic Deposits and a Global Perspective; USGS Scientific Investigations Report 2010-5220; USGS: Reston, VA, USA, 2010; p. 96.

99. Chakhmouradian, A.R.; Wall, F. Rare earth elements: Minerals, mines, magnets (and more). Elements 2012, 8, 333-340. [CrossRef]

100. Lambert, I.; Miezitis, Y.; Mackowski, S.; McKay, A. Australia's rare earth resources in global context. In International Geological Congress, Abstracts-Congres Geologique International, Resumes; International Geological Congress: Oslo, Norway, 2008; Volume 33, Abstract 1342645.

101. Environmental Protection Agency. Rare Earth Elements: A Review of Production, Processing, Recycling, and Associated Environmental Issues; US Environmental Protection Agency: Washington, DC, USA, 2012; EPA600/R-12/572; p. 96.

102. Gambogi, J. Rare earths. In U.S. Geological Survey Mineral Commodity Summaries; U.S. Geological Survey: Reston, VA, USA, 2013; pp. 128-129.

103. Palaparthi, J.; Chakrabarti, R.; Banerjee, D.; Guin, R.; Ghosal, S.; Agrahari, S.; Sengupta, D. Economically viable rare earth element deposits along beach placers of Andhra Pradesh, eastern coast of India. Arab J. Geosci. 2017, 10. [CrossRef]

104. Pike, D.R. Thorium and rare earth bearing minerals in the Union of South Africa. In Proceedings of the United Nations International Conference on Peaceful Uses of Atomic Energy, Geneva, Switzerland, 1-13 September 1958; pp. 91-96.

105. Young, E.J.; Sims, P.K. Petrography and Origin of Xenotime and Monazite Concentrations, Central City District, Colorado; U.S. Geological Survey Bulletin; USGS: Reston, VA, USA, 1961; pp. 273-299. 
106. Mariano, A.N.; Mariano, A.R. Rare earth mining and exploration in North America. Elements 2012, 8, 369-376. [CrossRef]

107. LeBas, M.J.; Keller, J.J.; Kejie, T.; Wall, F.F.; Williams, C.T.; Zhang, P. Carbonatite dykes at bayan Obo, inner Mongolia, China. Miner. Pet. 1992, 46, 195-228. [CrossRef]

108. Hutchinson, D.E.; Toussaint, L.F. Near-surface disposal of concentrated NORM wastes. Appl. Radiat. Isot. 1998, 49, 265-271. [CrossRef]

109. Paschoa, A.S. Potential environmental and regulatory implications of naturally occurring radioactive materials (NORM). Appl. Radiat. Isot. 1998, 49, 189-196. [CrossRef]

110. Padmanabhan, V.T. Radioactive minerals and private sector mining. Econ. Political Wkly. 2002, 37, 4365-4367.

111. Paschoa, A.S.; Dias da Cunha, K. A critical look at NORM in the monazite cycle. In Proceedings of the American Institute of Physics Conference Proceedings, Rio de Janeiro, Brazil, 7-12 October 2007; pp. 119-123.

(C) 2017 by the authors. Licensee MDPI, Basel, Switzerland. This article is an open access article distributed under the terms and conditions of the Creative Commons Attribution (CC BY) license (http:/ / creativecommons.org/licenses/by/4.0/). 


\title{
Review \\ Geochemistry of Monazite within Carbonatite Related REE Deposits
}

\author{
Wei Chen ${ }^{1, *}$, Huang Honghui ${ }^{1}$, Tian Bai ${ }^{1}$ and Shaoyong Jiang ${ }^{1,2}$ \\ 1 State Key Laboratory of Geological Processes and Mineral Resources, Collaborative Innovation Center for \\ Exploration of Strategic Mineral Resources, China University of Geosciences, Wuhan 430074, China; \\ huihuicug@163.com (H.H.); baitian_cug@163.com (T.B.); shyjiang@nju.edu.cn (S.J.) \\ 2 State Key Laboratory for Mineral Deposits Research, Department of Earth Sciences, Nanjing University, \\ Nanjing 210093, China \\ * Correspondence: wchen@cug.edu.cn; Tel./Fax: +86-027-6788-5096
}

Received: 15 July 2017; Accepted: 7 September 2017; Published: 27 September 2017

\begin{abstract}
Approximately $>50 \%$ of global rare earth element (REE) resources are hosted by carbonatite related deposits, of which monazite is one of the most important REE minerals. Monazite dominates more than 30 carbonatite-related REE deposits around the world, including currently exploited mineralization at Bayan Obo and Mount Weld. These deposits are widely distributed across all continents, except Antarctica. Though rare, monazite occurs as the primary mineral in carbonatite, and mostly presents as a secondary mineral that has a strong association with apatite. It can partially or completely replace thin or thick overgrowth apatite, depending on the availability of REE. Other mineral phases that usually crystallize together with monazite include barite, fluorite, xenotime, sulfide, and quartz in a carbonate matrix (e.g., dolomite, calcite). This review of monazite geochemistry within carbonatite-related REE deposits aims to provide information regarding the use of monazite as a geochemical indicator to track the formation history of the REE deposits and also supply additional information for the beneficiation of monazite. The chemical compositions of monazite are highly variable, and Ce-monazite is the dominant solid solution in carbonatite related deposits. Most monazite displays steep fractionation from $\mathrm{La}$ to $\mathrm{Lu}$, absent of either $\mathrm{Eu}$ or Ce anomalies in the chondrite normalized REE plot. The other significant components are huttonite and cheratite. Some rare sulfur-bearing monazite is also identified with an $\mathrm{SO}_{3}$ content up to $4 \mathrm{wt} \%$. A ${ }^{147} \mathrm{Sm} /{ }^{144} \mathrm{Nd}$ ratio with an average $\sim 0.071$ for monazite within carbonatite-related ores is similar to that of their host rocks $(\sim 0.065)$, and is the lowest among all types of REE deposits. Sm/Nd variation of monazite from a single complex reflects the differentiation stage of magma, which decreases from early to late. Based on the differences of $\mathrm{Nd}$ and $\mathrm{Sr}$ abundances, $\mathrm{Nd}$ isotopic composition for monazite can be used to track the magma source, whereas Sr isotopic composition records the signatures of the fluid source. Th-(U)-Pb age determination of the secondary monazite records variable thermal or metasomatic disturbances, and careful geochronological interpretation should be brought forward combined with other lines of evidence. $\mathrm{ThO}_{2}$ is the most difficult contamination in the beneficiation of monazite, luckily, the $\mathrm{ThO}_{2}$ content of monazite within carbonatite is generally low ( $\left.<2 \mathrm{wt} \%\right)$.
\end{abstract}

Keywords: monazite; carbonatite; geochemistry; REE deposits

\section{Introduction}

Rare earth metals are essential ingredients for modern industry and the in development of high technology products in our daily lives. Although not as rare in nature as their name implies, economic deposits are not common and currently the global production of rare earth element (REE) comes from only two ore-deposit types [1]. Carbonatite-related deposits (e.g., Bayan Obo, Mountain Pass) provide the world's light REE (LREE) and ion adsorption clay deposits in Southern China supply 
heavy REE (HREE) [1,2]. Carbonatite, a rare igneous rock, contains the highest REE concentrations of any of the igneous rocks, and is especially enriched in LREE [3]. The three most important REE minerals in carbonatite related deposits are bastnasite, monazite, and xenotime [2], and are also the only REE bearing minerals that have been extracted on a commercial scale [4]. Monazite is similar to bastnasite as a LREE ore mineral, but with slightly more HREE [5]. Monazite, together with niobate, fluorocarbonate and apatite, serve as the most useful carbonatite indicator minerals for specialty metal exploration [6].

Monazite $\left[(\mathrm{REE}) \mathrm{PO}_{4}\right]$ is ubiquitous in granitic and many metamorphic rocks, sand beach, and is a primary and hydrothermal mineral in carbonatite. Monazite is found throughout the world in placer deposits, beach sands, and important components of carbonatite related REE deposits, such as Bayan Obo and Mount Weld. It displays a variety of chemical compositions, with enrichments in most incompatible elements such as thorium and uranium, which makes monazite a good isotopic and geochronological indicator for the genesis of these rocks. The accommodation of Th and U into the monazite crystal without sustaining damage serves it as a potential host matrix for sequestering long-lived radionuclides [7]. On the other hand, thorium and uranium abundances in monazite present a negative aspect of mining and processing [5].

Monazite is a ubiquitous accessory phase in carbonatite and form economic REE deposits; however, no systematic investigation of this mineral has been provided in carbonatite-related REE deposits. This review aims to provide a summary of monazite geochemistry in carbonatite and related alkaline rocks. Furthermore, it will contribute information for the future study of monazite, which can be used as a geochemical indicator to track the formation history and also supply additional information for the beneficiation of monazite within these REE deposits.

\section{Distribution of Monazite Dominated Carbonatite REE Deposits}

Monazite-dominated carbonatite REE deposits have been identified worldwide, and their distribution is shown in Figure 1 and summarized in Supplementary Materials Table S1. They are widely distributed across all continents except Antarctica (Figure 1). Most of the REE deposits are carbonatite-related and contain dominant bastnasite, monazite, pyrochlore, apatite, xenotime, allanite, barite, and fluorite (Supplementary Materials Table S1). Several abundant monazite deposits are associated with phoscorite-nelsonite rocks in the alkaline complex (e.g., Purulia; Hongcheon). Some carbonatite REE deposits are bastnasite dominated with monazite in the secondary abundance (e.g., Bayan Obo, Mountain Pass). Monazite is the most dominant REE mineral in supergene deposits, such as Mount Weld and Araxa. Recent reviews on rare earth element related deposits can be found in References $[2,5,6]$.

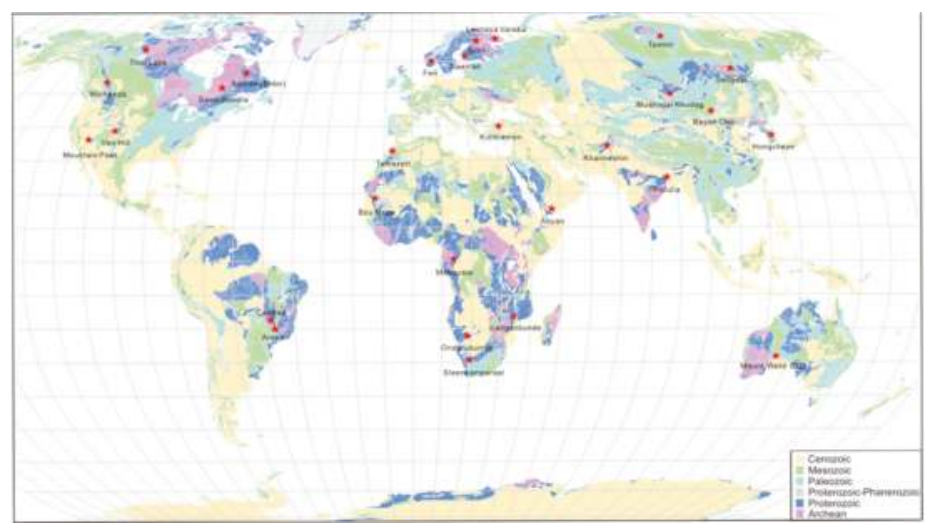

Figure 1. Geological map of the locations of monazite dominant carbonatite related REE deposits. 


\section{Texture Characteristics of Monazite}

Monazite can occur as a primary accessory mineral phase in carbonatite [8] with euhedral to subhedral grains that vary from $\sim 25$ to $\sim 200 \mu \mathrm{m}$ in size (e.g., Mountain Pass; Kangankunde Hill; Bayan Obo; Figure 2a,b). In thin sections, monazite appears in a variety of colors, from colorless to yellowish, greenish, and brownish $[9,10]$ (e.g., Figure 2c,d). More commonly, it is the product of metasomatic/hydrothermal alteration of the primary mineral assemblage within the carbonatite (e.g., apatite) or occurs along the fractures of the matrix carbonate as interstitial fillings or form veinlets or, which appears as fine-grained polycrystalline clusters (e.g., Figure 2e,f, or Figure 3) [11]. The secondary monazite commonly shares mineral associations with apatite, barite, fluorite, hematite, quartz, sulfide, bastnasite, xenotime, feldspar, titanite, synchysite, goyazite, and strontianite. Some monazite shows an association with K-feldspar [12,13] (e.g., Figure 2h), or is intergrown with albite [9] (e.g., Evate). The monazite aggregates display a close association with molybdenite in the Huanglongpu carbonatite (Figure 2i). Different generations of monazite can be found in the same rock or a large crystal, for example, huge monazite crystals $(>1 \mathrm{~mm})$ in a matrix of ankerite, apatite, pyrite and quartz have been identified with a euhedral to subhedral core in the Hongcheon complex, and the surrounding small grains in the cracked and resorbed rim that possibly formed as a result of late-stage hydrothermal activities [14] (Figure 2j).

The monazite-apatite association is quite common in carbonatite related deposits. Monazite partially or completely replaces apatite, and the replaced monazite displays a cracked nature [15] (Figure 3a; e.g., Sokli monazite). Secondary monazite usually occurs as small crystals (up to $30 \mu \mathrm{m}$ in size) on the edge, replacing apatite or is included within apatite crystals (Figure 3b). Commonly, monazite occurs as small crystals or polycrystalline aggregates (up to $20 \mu \mathrm{m}$ ) at the corroded LREE-rich rims of apatite (Figure 3d). Monazite sometimes occurs together with bastnasite as inclusions in apatite (Figure 3c; e.g., Naantali carbonatite [16]). The crystal size of monazite overgrowing apatite can be both small and large (Figure $3 \mathrm{~d}-\mathrm{f})$. Some monazite grains occur as very thin layer aggregates $(<10 \mu \mathrm{m})$ surrounding apatite or so-called girdles around the coarse fluorapatite, for instance, phoscorite from the district of Purulia, India [17] (Figure 3e). Large monazite overgrown apatite has been identified in several deposits [18] (up to $2 \mathrm{~mm}$ in diameter; Figure 3f; e.g., Abyan; Bayan Obo). These secondary monazites associated with apatite might form in a scenario where hydrothermal solutions rich in REEs permeated fresh carbonatite along fractures and reacted with apatite to produce pseudomorphs of polycrystalline monazite or overgrowth on the edge of apatite [8]. Apatite associated hydrothermal monazite is common in both magmatic and metamorphic rocks (e.g., Dabie Shan clinopyroxenite [19]). In carbonatite-related deposits, monazite has rarely been observed to form in carbonatite until the end stages of apatite crystallization. Though monazite can survive at temperatures much higher than $750{ }^{\circ} \mathrm{C}$, in carbonatite it is restricted to temperatures lower than $750{ }^{\circ} \mathrm{C}[20]$. 

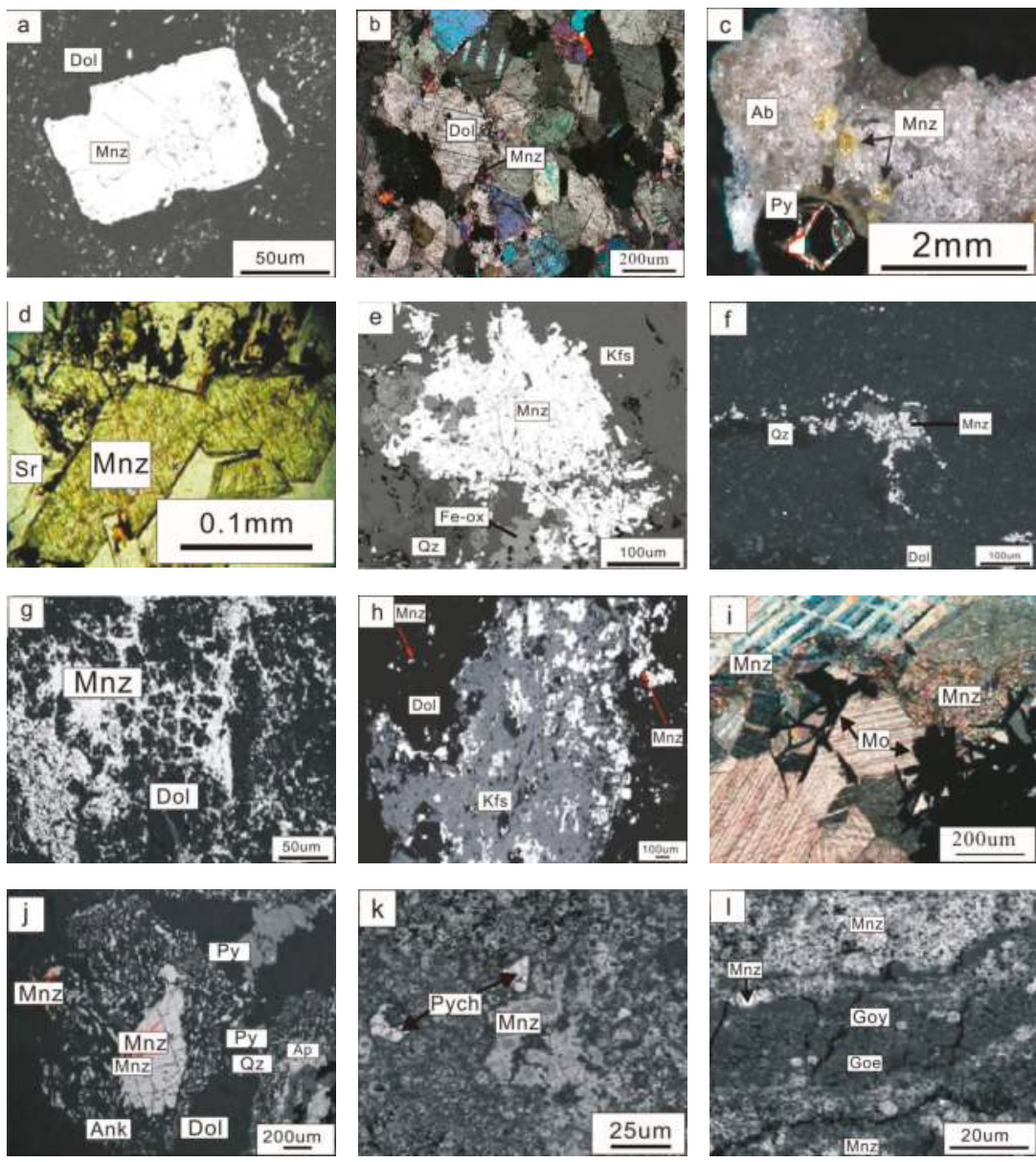

Figure 2. Petrographic images for monazite from carbonatite related REE deposits. (a) Backscattered electron (BSE) image of euhedral monazite in carbonatite from Mountain Pass, the United States [21]; (b) disseminated monazite within dolomite marble from Bayan Obo, Inner Mongolia, China; (c) yellow monazite crystals crystallized on the rim of albite matrix from Evate, Mozambique [9]; (d) green monazite occurs as disseminations in the strontianite matrix in Kangankunde, Malawi [10]; (e) BSE image of anhedral monazite in carbonatite from Mountain Pass, the United States [21]; (f) monazite in strongly foliated dolomite carbonatite with quartz laminae from the Cummins Range carbonatite, Australia [22]; (g) monazite net of veinlets in dolomite from Seligdar apatite deposit, Russia [11]; (h) backscattered electron image showing a vug in dolomite filled with potassium feldspar and monazite from the Wideeda carbonatite, Canada [12]; (i) monazite aggregates together with molybdenite in the calcite carbonatite from Huanglongpu, China; $(\mathbf{j})$ euhedral monazite core with small monazite grains in the cracked and resorbed rim from the Hongcheon complex, Korea [14]; (k,1) typical monazite-pyrochlore-crandallite ore in the Tomtor deposit (Russia); and relict pyrochlore crystal in monazite and goyazite as colloform globular segregations in a colloform goethite aggregate [23]. $\mathrm{Ab}=$ albite; Ank = ankerite; $\mathrm{Ap}=$ apatite; $\mathrm{Mnz}=$ monazite; Dol = dolomite; Goe = Goethite; Goy = goyazite; Kfs = K-feldspar; Mo = Molybdenite; Py = pyrite; Pych = pyrochlore; and Qz = Quartz. 

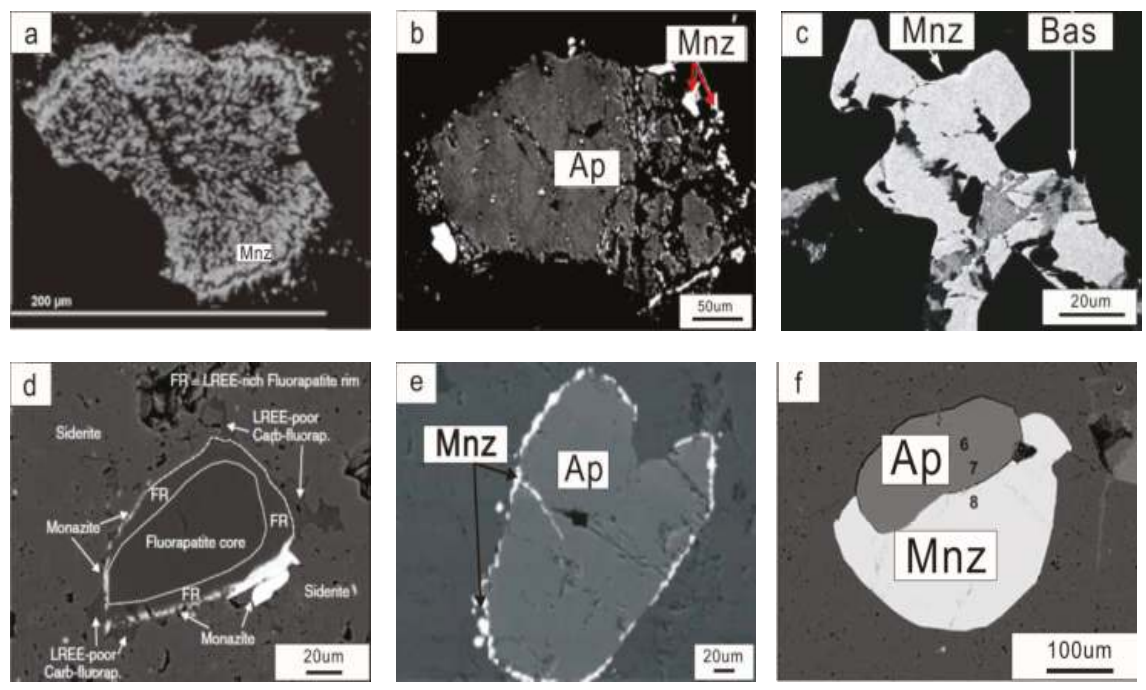

Figure 3. BSE images for monazite and apatite mineral association in carbonatite related alkaline rocks. (a) apatite grain completely replaced by monazite in carbonatite from the Sokli complex, Finland [15]; (b) monazite on the edge or included within the heterogeneous apatite in the apatite-dolomite ore from the Seligdar deposit, Russia [11]; (c) monazite inclusions within apatite in association with bastnaesite inclusions from the Naantali carbonatite, Finland [16]; (d) apatite crystal with a LREE-rich rim partly replaced and overgrown by monazite associated with LREE-poor carbonate-apatite in the Matongo carbonatite, Burundi [22]; (e) monazite grains girdling around coarse apatite in the Purulia phoscorite, India [17]; and (f) monazite overgrowth on apatite in the Abyan carbonatite, Yemen Republic [18]. $\mathrm{Ap}=$ apatite; Bas = bastnasite; and Mnz = monazite.

The most common supergene REE mineral in carbonatite and related alkaline rocks is monazite, and it has been found in laterite that derived from the chemical weathering of carbonatites, e.g., Mt. Weld, Australia [24]; Araxa and Catalao I, Brazil [8,25]; Tomtor, Russia [23]; Mrima Hill, Kenya [26]; Mabouni, Gabon; and several other carbonatite laterites in the Amazon region of Brazil [27]. Carbonate minerals are easily dissolved when carbonatite is subjected to chemical weathering, and $\mathrm{Ca}$ and $\mathrm{Mg}$ can be removed, leaving behind less mobile elements (e.g., REEs and Sr) [8]. Porous monazite aggregates in the carbonatite laterite from Mt. Weld contain inclusions of apatite, plumbogummite, goethite, cerianite, ilmenite, quartz, and Mn minerals [24]. Monazite spherulitic aggregates composed of hollow tubes ( $300 \mu \mathrm{m}$ in diameter), resembling biomorphic structures, have been shown in the Tomtor deposit (Figure 2k,l) [23]. Supergene monazite coexists with minerals of hydrothermal origin, e.g., barite, crandallite group minerals, and sulfides $[23,25]$. Halloysite in aggregates have been reported for Tomtor, also confirming hydrothermal activity. The presence of thermal waters was observed in some of the supergene monazite formation sites (e.g., Catalao I complex) [28].

\section{Chemical Compositions}

\subsection{REE Compositions}

Monazite has the nominal composition (LREE) $\mathrm{PO}_{4}$, and those within carbonatite related REE deposits usually show significant variation in chemical composition [29]. Without including the exceptions found in Lesnaya Varaka [29], the total $\mathrm{REE}_{2} \mathrm{O}_{3}$ contents within monazite range from 49.6 to $74.13 \mathrm{wt} \%$ and the average value is $64.31 \mathrm{wt} \%$ (Supplementary Materials Table S2). Depending on the dominant light rare earth element, the following varieties have been identified including 
monazite-La [30], monazite-Ce [31], and monazite-Nd [32]. Monazites formed within carbonatite related complexes are usually a Ce dominated phosphate, and the $\mathrm{Ce}_{2} \mathrm{O}_{3}$ content generally varies between 8.74 and $38.46 \mathrm{wt} \%$ with an average of $32.47 \mathrm{wt} \%$, which is much higher compared to $\mathrm{La}_{2} \mathrm{O}_{3}$ and $\mathrm{Nd}_{2} \mathrm{O}_{3}$ (Supplementary Materials Table S2; Figure 4a). $\mathrm{La}_{2} \mathrm{O}_{3}$ composition varies from 0.46 to $27.60 \mathrm{wt} \%$ in different carbonatite and related alkaline rocks, with an average value of $18.09 \mathrm{wt} \%$ (Supplementary Materials Table S2). The highest La-bearing monazite has been identified from the Abyan complex, with an average $\mathrm{La}_{2} \mathrm{O}_{3}$ content of $23.58 \mathrm{wt} \%$ [18]. The content of $\mathrm{La}_{2} \mathrm{O}_{3}$ also varies significantly in the same rock sample, depending on the crystallization stage (e.g., $15.44-21.75 \mathrm{wt} \%$; Purulia phoscorite [17]). $\mathrm{Nd}$ is less enriched in monazite compared to La, and the $\mathrm{Nd}_{2} \mathrm{O}_{3}$ composition varies from 4.38 to $17.41 \mathrm{wt} \%$ with an average of $9.43 \mathrm{wt} \%$ (Supplementary Materials Table S2). Monazite from Naantali carbonatite contains the highest $\mathrm{Nd}_{2} \mathrm{O}_{3}$ content, ranging from 14.79 to $17.38 \mathrm{wt} \%$ [16], and these display the lowest $(\mathrm{La} / \mathrm{Nd})_{\mathrm{N}}$ ratios ( 1.5; Supplementary Materials Table S2). Monazite in the highly altered rocks is depleted in $\mathrm{La}, \mathrm{Ce}$, and $\mathrm{Pr}$ when compared to those in unaltered or partially altered ferro carbonatite in the Kola carbonatite [20]. Composition variations of La and $\mathrm{Nd}$ within a single monazite have been found at Kangankunde, which display differential REE uptake by sector growth of the crystal [33]. The contents of $\mathrm{La}, \mathrm{Pr}$, and $\mathrm{Nd}$ have been shown to decrease from core to rim for Hongcheon monazite, whereas the compositions of $\mathrm{Ce}, \mathrm{Eu}$, and $\mathrm{Gd}$ tend to increase [34].

MREE and HREE are normally depleted in monazite compared to LREE, and not many have been reported. $\mathrm{Gd}$ and Eu are both the dominant MREEs in monazite. $\mathrm{A} \mathrm{Eu}_{2} \mathrm{O}_{3}$ composition of $\sim 1.1 \mathrm{wt} \%$ has been reported for Naantali monazite [16], whereas Hocheong monazite contains $0.46-0.92 \mathrm{wt} \%$ of $\mathrm{Eu}_{2} \mathrm{O}_{3}$ [34]. The latter also had the highest $\mathrm{Gd}_{2} \mathrm{O}_{3}$ content ( $\sim 4 \mathrm{wt} \%$ ) identified for monazite within carbonatite-related deposits [34]. These contents are higher compared to those for metamorphic monazite, of which $\mathrm{Eu}_{2} \mathrm{O}_{3}$ is generally below $0.5 \mathrm{wt} \%$ [35]. Based on these published data, MREE contents within monazite are restricted to less than $2 \mathrm{wt} \%$ and HREE abundances are even lower ( $0.5 \mathrm{wt} \%$; Supplementary Materials Table S2).

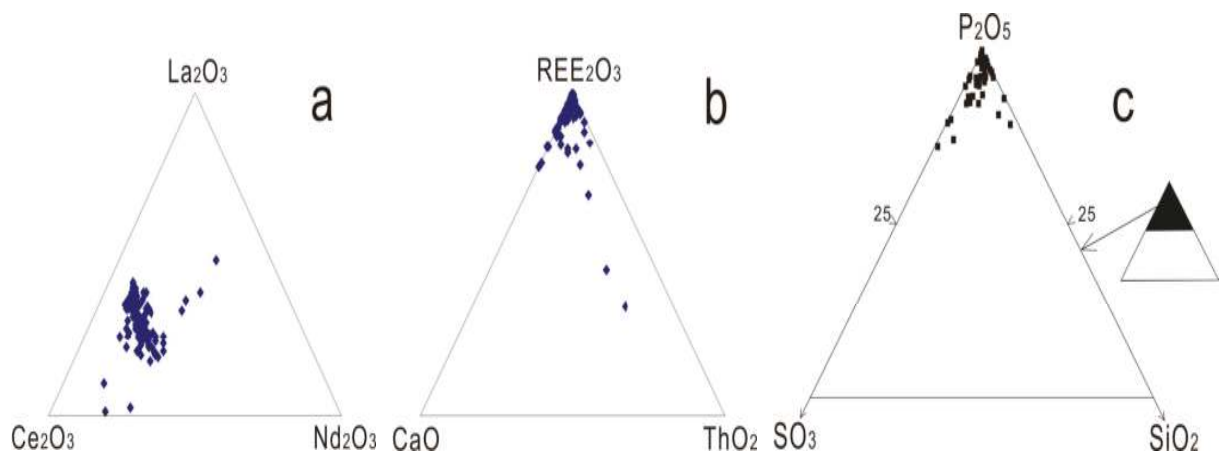

Figure 4. Compositional triplots of monazite from carbonatite related REE deposits. (a) $\mathrm{La}_{2} \mathrm{O}_{3}-\mathrm{Ce}_{2} \mathrm{O}_{3}-\mathrm{Nd}_{2} \mathrm{O}_{3}$; (b) $\mathrm{REE}_{2} \mathrm{O}_{3}-\mathrm{ThO}_{2}-\mathrm{CaO}$; and (c) $\mathrm{P}_{2} \mathrm{O}_{5}-\mathrm{SO}_{2}-\mathrm{SiO}_{2}$.

Monazite from carbonatite related deposits generally displays a straight linear trend decreasing from $\mathrm{La}$ to $\mathrm{Lu}$ in chondrite normalized REE diagrams (Figure 5a). The absence of the Ce anomaly in the REE patterns suggests reducing environments during monazite crystallization. The smooth Eu patterns are distinct for monazite formed in carbonatite related environments [34], whereas granitic monazite is commonly characterized by a positive Eu anomaly, and a negative Eu anomaly is typical for metamorphic monazite [35]. The slopes of the chondrite normalized REE profiles for monazite are shallower than those of REE minerals, such as bastnasite, ancylite and cordylite, and comparable to those of parasite and synchysite in the Wicheeda carbonatite, which suggests that monazite with parasite and synchysite are more enriched in HREEs [12]. 

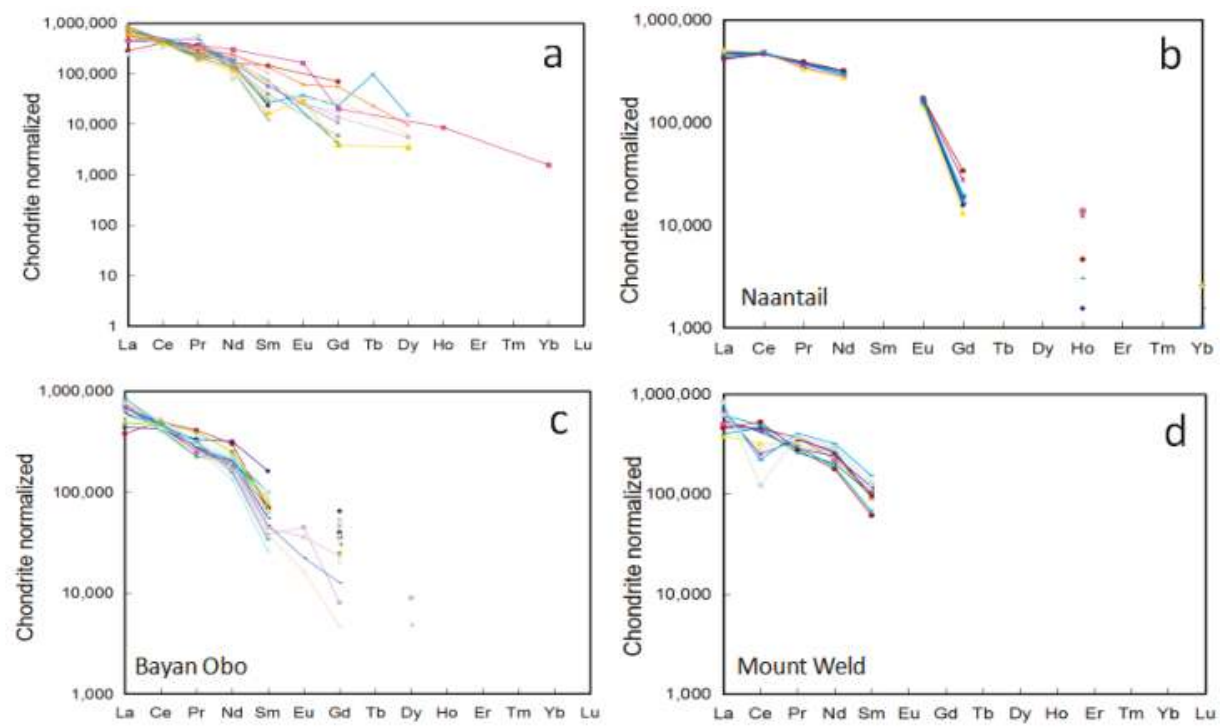

Figure 5. Chondrite normalized REE patterns for monazite from carbonatite related REE deposits. (a) all deposits; (b) Naantali; (c) Bayan Obo; and (d) Mount Weld.

The chondrite normalized REE patterns pivot about the Ce position observed for monazite from Kangankunde, Abyan, Bayan Obo, and Naantali $[18,20,33,36]$ (Figure 5b,c). The pivot point corresponds to $\mathrm{Ce}_{2} \mathrm{O}_{3}$ contents of 31-34 wt \% (Supplementary Materials Table S2; Figure 5b,c). La and Ce decoupled with total LREE variations, and decreased relative to Ce (e.g., Bayan Obo; Figure 5c). Wall and Zaitsev [20] proposed that this was common among mineralized carbonatite and correlates with increasing volatile activity accompanying mineralization, with a wider range of La and $\mathrm{Nd}$ representing hydrothermal activity. Small differences in the probability of uptake distinct REE (e.g., La, Nd) onto different growth surfaces of monazite results in a pivoting effect at Ce [20]. The variations of $\mathrm{La} / \mathrm{Nd}$ ratios have been used to indicate different stages of the carbonatite evolution. As indicated by Kim et al. [34], monazite within the early-stage carbonatite at Hongcheon contains lower $\mathrm{La} / \mathrm{Nd}$ ratios (2.98-3.94) compared to those in the late-stage monazite ( $\mathrm{La} / \mathrm{Nd}=3.28-4.57)$. In the magmatic-hydrothermal system, Smith et al. [37] suggested that minerals with lower La/Nd ratios formed from dominantly aqueous solutions. The chondrite normalized $\mathrm{La} / \mathrm{Nd}$ ratio varied from $\sim 3-7$ in early disseminated monazite at Bayan Obo, whereas vein-hosted monazite was characterized by ratios in the range of $\sim 4.8-5.8$ [37].

The Ce pivot point was not observed for monazite in the Mt. Weld carbonatite laterite (Figure 5d), some of the monazites display a distinct negative Ce anomaly that might correspond to crystallization in an oxidized environment. Supergene monazite during the weathering process shows higher $Y$ and MREE contents when compared to the primary monazite from the same complex [8]. In the Catalao I carbonatite complex, weathered monazite displayed a less steep REE pattern (i.e., lower $\mathrm{La} / \mathrm{Nd}$ ratio) when compared to those within carbonatite [28]. The detailed chemical compositions of monazite within carbonatite related environments can be found in Supplementary Materials Table S2 [11-14,16-18,20,23,24,29,30,34,35,37-43].

\subsection{Various Element Accommodations in Monazite}

Monazite, a LREE phosphate, also embraces various element accommodations in the crystal. Most monazite contains additional $\mathrm{Th}, \mathrm{U}, \mathrm{Ca}, \mathrm{Sr}, \mathrm{Si}$, and $\mathrm{Pb}$, and some also accommodate S (Figure 4b,c). 
$\mathrm{ThO}_{2}$ content in monazite from carbonatite related deposits are commonly low (e.g., <2 wt \%; Supplementary Materials Table S2) compared to those in metamorphic and sedimentary deposits [27]. Possible substitution schemes to accommodate Th in monazite include:

$$
\begin{gathered}
2 \mathrm{Ce}^{3+} \leftarrow \mathrm{Ca}^{2+}\left(\mathrm{Sr}^{2+}\right)+\mathrm{Th}^{4+} \\
\mathrm{Ce}^{3+}+\mathrm{P}^{5+} \leftarrow \mathrm{Th}^{4+}+\mathrm{Si}^{4+}
\end{gathered}
$$

The first substitution scheme represents a solid solution series between monazite $\left(\mathrm{CePO}_{4}\right)$, cheralite [CaTh $\left.\left(\mathrm{PO}_{4}\right)_{2}\right]$, and $\operatorname{SrTh}\left(\mathrm{PO}_{4}\right)_{2}$ [39], commonly known as the cheralite substitution $[44,45]$. Accommodation of Th in monazite may involve a coupled substitution with $\mathrm{Si}$ as listed as the second scheme, which is known as the huttonite substitution [20,44,45]. Both substitutions contribute to the accommodation of Th in Naantali monazite (with a range of 1.1-1.5 wt \% $\mathrm{ThO}_{2}$ ) though the huttonite mechanism may play the dominant role given that better correlation between $\mathrm{ThO}_{2}$ and $\mathrm{SiO}_{2}$ has been identified (Figure 6a,b) [16]. Again, both huttonite and cheralite solid substitution in monazite have been identified for the Sokli complex and the Lesnaya Varaka complex, with $\mathrm{ThO}_{2}$ content as high as 34.94 wt \% (Figure 6c-f; Supplementary Materials Table S2) [15,23]. These monazites contain high and variable amounts of $\mathrm{SrO}$ ranging from 0.92 to $4.2 \mathrm{wt} \%$ and $\mathrm{CaO}$ contents ranging from 0.92 to $4 \mathrm{wt} \%$, which display co-substitution with Th (Figure 6e,f). The cheralite substitution mechanism may indicate selective removal of $\mathrm{Ca}$ and $\mathrm{Sr}$ from apatite in the presence of a REE-rich hydrothermal solution as well as the immobility of $\mathrm{P}$, which is indicated by the petrographic texture of monazite replacing apatite (Figure 3). $\mathrm{ThO}_{2}$ content variation has also been identified within the large crystals, for instance, those from the Abyan deposit were observed to decrease from $>2 \mathrm{wt} \%$ in the center to $<0.5 \mathrm{wt} \%$ at the rim and along the fractures [18]. The high Th content is most common in high-temperature monazite [20].

Monazite can contain appreciable $\mathrm{Si}$ and $\mathrm{S}$, with up to $2.65 \mathrm{wt} \%$ of $\mathrm{SiO}_{2}$ and $4.06 \mathrm{wt} \%$ of $\mathrm{SO}_{3}$ (Supplementary Materials Table S2; Figure 4c). The accommodation of Si is dominantly controlled by the huttonite substitution as indicated by the positive linear correlation between $\mathrm{ThO}_{2}$ and $\mathrm{SiO}_{2}$, and the negative correlation between $\mathrm{Ce}_{2} \mathrm{O}_{3}+\mathrm{P}_{2} \mathrm{O}_{5}$ and $\mathrm{ThO}_{2}+\mathrm{SiO}_{2}$ (Figure 6c,d). Appreciable $\mathrm{SO}_{3}$ contents (0.61-4.06 wt \%) have only been observed in monazite from Mushgai Khudag, Kandaguba, Vuorijarvi, and Khaluta $[42,46,47]$ (Supplementary Materials Table S2). Furthermore, the accommodation of sulfur may be controlled by the third substitution scheme; however, it is poorly supported by the currently available data. Monazite from the Cataolo I complex consists of low $\mathrm{REE}_{2} \mathrm{O}_{3}(\sim 50 \mathrm{wt} \%)$ and $\mathrm{P}_{2} \mathrm{O}_{5}$ $(\sim 25 \mathrm{wt} \%)$ as well abundant $\mathrm{SrO}(\sim 2.6 \mathrm{wt} \%)$ and $\mathrm{CaO}(\sim 1.2 \mathrm{wt} \%)$ contents, which could also possibly contain some sulfur or thorium in the crystal; however, both sulfur and thorium were not analyzed in the dataset [28]. Different $\mathrm{SO}_{3}$ bearing domains in patchy zoned monazite crystals from the Rogaland granulite have been investigated in-situ with $\mathrm{U}-\mathrm{Th}-\mathrm{Pb}$ ages, and the results show that $\mathrm{S}$ contents in monazite could possibly be used to discriminate different generations of monazite [40].

$$
\mathrm{Ce}^{3+}+\mathrm{P}^{5+} \leftarrow \mathrm{Ca}^{2+}\left(\mathrm{Sr}^{2+}\right)+\mathrm{S}^{6+}
$$

Arsenic may substitute for $\mathrm{P}$ in monazite, though is quite rarely identified in carbonatite-related environments [48]; about 0.27-1.02 wt \% of $\mathrm{As}_{2} \mathrm{O}_{5}$ has been reported for Nataanli monazite [16]. Monazite with $\mathrm{F}$ or $\mathrm{Cl}$ may indicate the metasomatic origin of the crystal, which is a hydrothermal product from apatite (Supplementary Materials Table S2). Monazite [(REE) $\left.\mathrm{PO}_{4}\right]$ can also contain water in the crystal structure and becomes euhedral crystals as hexagonal (REE) $\mathrm{PO}_{4} \cdot \mathrm{nH}_{2} \mathrm{O}[20]$. 

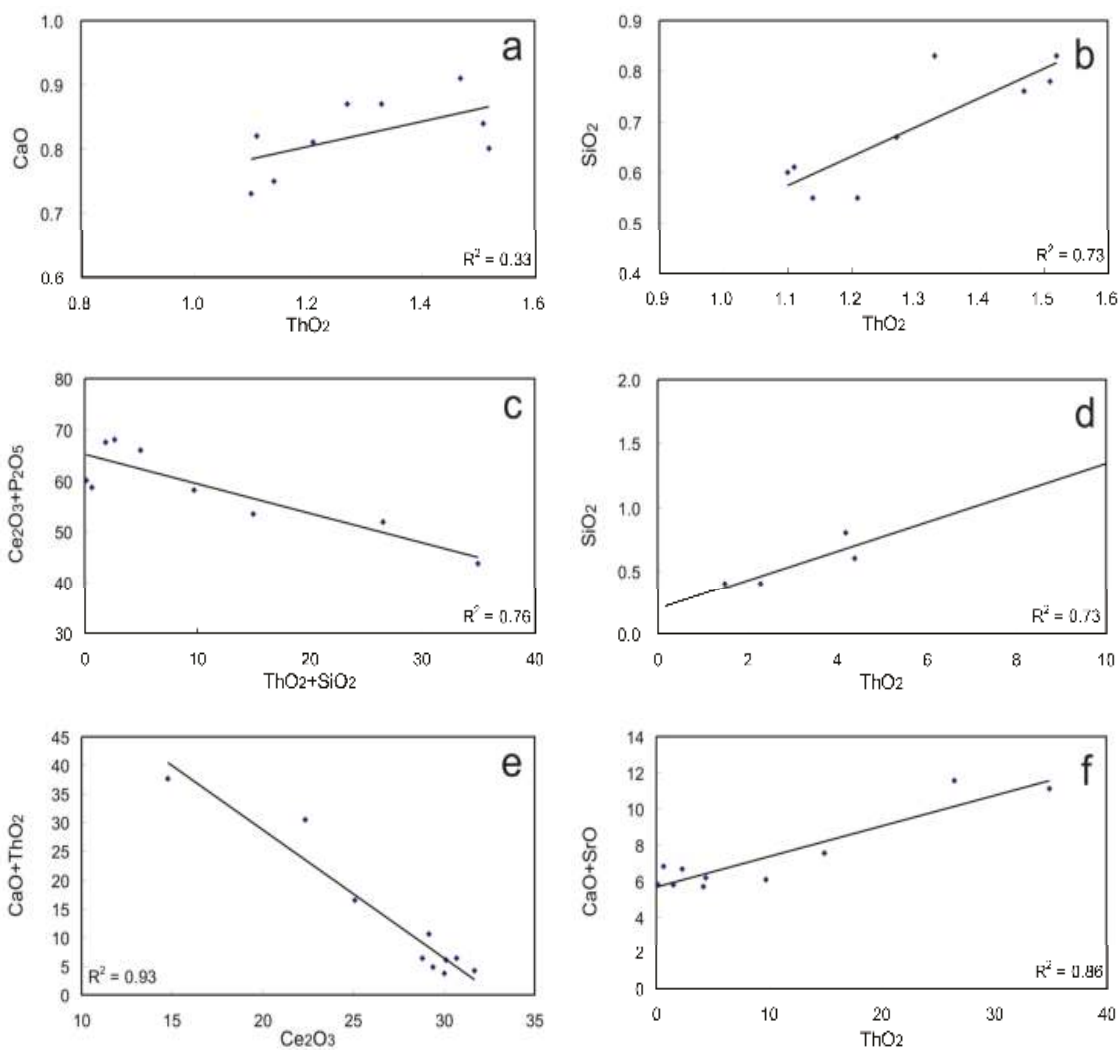

Figure 6. Substitution schemes for monazite from carbonatite related REE deposits. (a,b) dominated huttonite substitution scheme recorded for Naantali monazite; $(\mathbf{c}-\mathbf{f})$ huttonite and cheralite substitution for monazite from the Sokli and Lesnaya Varaka complex.

\section{Isotope Geochemistry}

Monazite, the dominant LREE phosphate, could ideally serve as a Sm-Nd isotopic indicator, widely used for Sm-Nd dating and Nd isotopic studies. Carbonatite related REE deposits are known to be characterized by large LREE to HREE fractionations, and display low $\mathrm{Sm} / \mathrm{Nd}$ ratios [3]. Monazite within carbonatite related REE deposits consists of lower $\mathrm{Sm} / \mathrm{Nd}$ when compared to those formed in other environments [2] (e.g., alkaline complex and pegmatite; Supplementary Materials Table S2). The average ${ }^{147} \mathrm{Sm} /{ }^{144} \mathrm{Nd}$ ratio is 0.065 for carbonatite related deposits, for alkaline complex and pegmatites it is 0.122 , and 0.091 for IOCG $=[2]$. The ${ }^{147} \mathrm{Sm} /{ }^{144} \mathrm{Nd}$ ratio for the monazite investigated in this study was composed of an average ratio of 0.071 , similar to that for carbonatite related REE deposits and distinctly lower than other rocks. This, in general, suggested that the $\mathrm{Sm} / \mathrm{Nd}$ ratio in monazite had a correlation with the signature of their host (rocks/magma) source. However, highly variable ${ }^{147} \mathrm{Sm} /{ }^{144} \mathrm{Nd}$ ratios $(0.002-0.270)$ have been identified for monazite in those carbonatite related REE deposits (Supplementary Materials Table S2), which indicates that the Sm/Nd ratio for monazite crystallized from each specific complex is further controlled by the evolution of the magma, pressure, and temperature. LREE generally becomes more enriched through carbonatite magma differentiation, hence a lower $\mathrm{Sm} / \mathrm{Nd}$ ratio in monazite indicates crystallization from more evolved magma/fluid.

Since $\mathrm{Nd}$ is a major element in monazite (with a $\mathrm{Nd}_{2} \mathrm{O}_{3}$ composition of $\sim 10 \mathrm{wt} \%$ in average), monazite, especially in ore rocks, is definitely the dominant mineral, which reflects the $\mathrm{Nd}$ isotope 
composition of the carbonatite whole rock [14]. REEs are generally enriched in carbonatite magma and supply the nutrients for the crystallization of monazite regardless of the fluid or thermal trigger. Commonly, hydrothermal fluid serves as a trigger for the deposition of REE minerals including monazite and bastnasite in carbonatites. The hydrothermal fluid is released from surrounding country rocks or meteorite water, which is not as enriched in REEs compared to that of evolved carbonatite melts/liquids. Thus, though most monazite is secondary in origin, their $\mathrm{Nd}$ isotopic compositions still record the signature of their carbonatite magma source. The Sm-Nd isotopic system of monazite and whole rock for Bayan Obo dolomite marble have been intensely investigated [49]. Zhu et al. [49] showed that despite the variable ages from thermal disturbance, the monazite and whole rock shared the same original ${ }^{143} \mathrm{Nd} /{ }^{144} \mathrm{Nd}$ ratios at $1.3 \mathrm{Ga}$.

$\mathrm{SrO}$ content in monazite from carbonatite related ore also varies greatly, with the most enriched up to $8 \mathrm{wt} \%$ (e.g., Lesnaya Varaka; Supplementary Materials Table S2). In general, SrO content in monazite $(\sim 1.5 \mathrm{wt} \%)$ is not as high compared to $\mathrm{Nd}_{2} \mathrm{O}_{3}$. In the carbonatite samples, the dominate carbonate mineral (e.g., dolomite or calcite) probably hosts the $\mathrm{SrO}$, since the $\mathrm{Sr}$ abundance is comparable to, or even higher than, monazite, and they have larger modal compositions $(>50 \%)$. It has also been proposed that as most monazite occurs as a secondary phase in carbonatite related complexes, Sr isotopes may be unreliable as source signatures of the magma [20]. Furthermore, it is quite possible that some of the monazite might reflect signatures of the open-system fluid, which might contain some $\mathrm{Sr}$ (e.g., fluid evolved from limestone). As such, a combined $\mathrm{Sr}$ and $\mathrm{Nd}$ isotopic investigation of monazite could be useful to track the original magma source and secondary alteration.

\section{Geochronology}

Monazite has long been used as Th- $\mathrm{Pb}$ and $\mathrm{U}-\mathrm{Pb}$ chronometers in various environments, and recent developments of in-situ methods have enabled the examination of these chronometers in more detail $[50,51]$. Of note is that fluid-induced recrystallization constitutes an efficient way to reset monazite chronometers [52]. Though U-Pb and $\mathrm{Th}-\mathrm{Pb}$ systematics can be highly disturbed, they may ultimately provide meaningful magmatic or fluid-alteration ages $[45,53]$.

Monazite formed within carbonatite related deposits usually contains high $\mathrm{ThO}_{2}$ contents with relatively low $\mathrm{U}$ and $\mathrm{Pb}$ abundances $[18,21,54]$. Most of the age dating results use $\mathrm{Th}-\mathrm{Pb}$ ages due to the analytical limitations with low- $\mathrm{U}$ analyses, i.e., discordant $\mathrm{Pb} / \mathrm{U}$ and $\mathrm{Pb} / \mathrm{Th}$ dates have been identified for monazite with depleted U contents (e.g., Cummins Range monazite) [55]. Th released during monazite dissolution is probably incorporated into newly-formed overgrowth rims, which results in Th-rich and $\mathrm{Pb}$-depleted zones and gives younger ages [50-53]. The variable monazite ages (as observed by several investigations for Bayan Obo) record the younger metasomatic age rather than the mid-proterozoic formation age recorded by the Sm-Nd system $[49,56]$.

\section{Beneficiation of Monazite}

Rare earth mining of can be divided into three historic eras: (1) monazite-placer; (2) Mountain Pass; and (3) Bayan Obo. Both of the latter deposits are bastnasite dominated with associated monazite. Traditionally, the most important deposits for monazite extraction are beach sands and river placers, and are often processed as by-products of ilmenite, zircon, and cassiterite mining [27]. They are typically concentrated via initial high-capacity gravity separation steps to take advantage of the high specific gravity of monazite (greater than 5), whereas typical gangue minerals in these deposits have specific gravities less than 3.5 [4]. These are followed by additional gravity, magnetic, electrostatic and occasionally flotation separation steps [55]. These monazites are typically high in $\mathrm{ThO}_{2}(1-27 \mathrm{wt} \%)$ [57] with extremes consisting of pure huttonite $(79.21 \mathrm{wt} \%$; [46]), which are much higher compared to carbonatite related REE deposits (generally $<2 \mathrm{wt} \%$; Supplementary Materials Table S2).

Recently, monazite has been mined in supergene carbonatite complexes such as Mt. Weld in Australia, which is claimed to contain the highest grade known REE deposit in the world [58]. The Mt. Weld mine has a conventional open-pit operation and was concentrated in the first phase 
using flotation technology; the second phase was processed in the Lynas advanced materials plant in Malaysia, which possibly include steps of calcinations, caustic conversion, acid leaching, and solvent extraction [58].

Acid bake leach and alkaline bake/pug roast leach are efficient processing routes in extracting high percentages of REEs and actinides and have economic advantages [59]. Leach processing is not selective and usually requires a series of downstream separation techniques [59]. Organophosphorus extractants have been extensively employed in the extraction and separation of rare earth elements, and neutral phosphine oxide is the most widely used due to high stability, low aqueous solubility, and rapid phase disengagement $[60,61]$. For instance, recent studies have investigated the extraction and separation of $\mathrm{La}, \mathrm{Ce}, \mathrm{Pr}, \mathrm{Nd}, \mathrm{Sm}, \mathrm{Yb}$, and Y from monazite using CYANEX 923 in kerosene $[59,62,63]$, and detailed recovery processing of REEs from monazite can be found in the work of Aly et al. [59]. The extraction process of radioactive elements of Th and U from monazite was investigated by El-Hefny et al. [62] and El-Nadi et al. [64]. Except for the extremely high Th-monazite, rarely-identified in carbonatite, most REE extraction from monazite in carbonatite-related deposits follow the processing described by Aly et al. [59]. Furthermore, Maes et al. [65] proposed a two-stage recovery strategy focused on the recovery of $\mathrm{Nd}$ and La from monazite that combined microbially based leaching with electro-chemical extraction. The radioactive element thorium and counter-ions phosphate and citrate were proven to effectively separate from REEs in the anolyte, which allows for the sustainable reuse of the leaching agent [41]. Currently, REEs have a low price in the global market, especially the LREEs. The price for $\mathrm{Nd}_{2} \mathrm{O}_{3}$ (USD\$38-40 kg-1) is much higher than $\mathrm{La}_{2} \mathrm{O}_{3}$ and $\mathrm{Ce}_{2} \mathrm{O}_{3}\left(\mathrm{US} \$ 2 \mathrm{~kg}^{-1}\right.$ ), and, even for $\mathrm{Nd}$, it is currently not sufficient to balance the power costs $\left(\$ 314 \mathrm{~kg}^{-1}\right.$ for $\left.\mathrm{Nd}\right)$ using environmentally-friendly technology to recover the REEs [65].

\section{Conclusions}

Monazite is one of the most important REE minerals for over 30 carbonatite related REE deposits worldwide, including the current open mines at Mt. Weld and Bayan Obo. These deposits are distributed widely across all continents except Antarctica. Monazite occurs as a primary crystal in carbonatite (though rare), and mostly presents as a secondary mineral phase that shows strong association with apatite. It can partially or completely replace apatite, or form thin or thick overgrowth apatite depending on the availability of REEs. Other mineral phases that usually crystallize with monazite include barite, xenotime, bastnasite, sulfide, quartz, and so on.

The chemical compositions of monazite display variable compositions, and Ce-monazite is the dominant solid solution in carbonatite related REE deposits. Most of the monazites display steep fractionation from $\mathrm{La}$ to $\mathrm{Lu}$ without $\mathrm{Eu}$ or Ce anomalies in the chondrite normalized REE patterns. They display a pivot point at $\mathrm{Ce}$, and $\mathrm{La}$ and $\mathrm{Nd}$ vary depending on availability. The other two dominant components are huttonite and cheratite that both contribute to the accommodation of Th. Some rare sulfur bearing monazite has also been identified with $\mathrm{SO}_{3}$ up to 4 wt $\% .{ }^{147} \mathrm{Sm} /{ }^{143} \mathrm{Nd}$ ratios with an average value of $\sim 0.071$ for monazite within carbonatite related ores were similar to their host rocks ( 0.065) and were the lowest compared to other REE deposits. Nd isotopic composition for monazite could be used to track the source, whereas $\mathrm{Sr}$ isotopic composition could possibly reflect some signature of the fluid source. Th- $\mathrm{U}-\mathrm{Pb}$ age determination of monazite may also record variable thermal or metasomatic disturbances, and careful geochronological interpretation should be brought forward. $\mathrm{ThO}_{2}$ is the most difficult contamination in the beneficiation of monazite, though luckily, high $\mathrm{ThO}_{2}$ contents are rarely identified in carbonatite related deposits.

Supplementary Materials: The following are available online at www.mdpi.com/2079-9276/6/4/51/s1. Table S1: Description of monazite dominant carbonatite related REE deposits, Table S2: Chemical composition of monazite within carbonatite and associated alkaline rocks.

Acknowledgments: The authors would like to thank Hangyu Liu from the China University of Geosciences (Wuhan) for offering samples from Bayan Obo for investigation as well as Yuancan Ying, Jue Lu, and Fan Yang from the same institute for the data collection and constructive suggestions in preparation of this manuscript. 
This study is supported by the National Natural Science Foundation of China (No. 41402046, 41673035, 41530211), the Fundamental Research Funds for the Central Universities and the special fund from the State Key Laboratory of Geological Processes and Mineral Resources (No. MSFGPMR03-2).

Conflicts of Interest: The authors declare no conflict of interest.

\section{References}

1. Verplank, P.L. The role of fluids in the formation of rare earth element deposits. Procedia Earth Planet. Sci. 2017, 17, 758-761. [CrossRef]

2. Weng, Z.H.; Jowitt, S.M.; Mudd, G.M.; Haque, N. A detailed assessment of global rare earth element resources: Opportunities and challenges. Econ. Geol. 2015, 110, 1925-1952. [CrossRef]

3. Chakhmouradian, A.R.; Zaitsev, A.N. Rare earth mineralization in igneous rocks: Sources and processes. Elements 2012, 8, 347-354. [CrossRef]

4. Jordens, A.; Cheng, Y.P.; Waters, K.E. A review of the beneficiation of rare earth element bearing minerals. Miner. Eng. 2013, 41, 97-114. [CrossRef]

5. Jha, M.K.; Kumari, A.; Panda, R.; Kumar, J.R.; Yoo, K.; Lee, J.Y. Review on hydrometallurgical recovery of rare earth metals. Hydrometallurgy 2016, 165, 2-26. [CrossRef]

6. Mackay, D.A.R.; Simandl, G.J.; Ma, W.; Redfearn, M.; Gravel, J. Indicator mineral-based exploration for carbonatites and related specialty metal deposits-A QEMSCAN orientation survey, British Columbia, Canada. J. Geochem. Explor. 2016, 165, 159-173. [CrossRef]

7. Decheux, N.; Clavier, N.; Podor, R. Monazite as a promising long-term radioactive waste matrix: Benefits of high-structural flexibility and chemical durability. Am. Mineral. 2013, 98, 833-847. [CrossRef]

8. Mariano, A.N. Nature of Economic Mineralization in Carbonatites and Related Rocks. In Carbonatites: Genesis and Evolution; Unwin: London, UK, 1989.

9. Hurai, V.; Paquette, J.L.; Huraiova, M.; Slobodnik, M.; Hvozdara, P.; Siegfried, P.; Gajdosova, M.; Milovska, S. New insights into the origin of the Evate apatite-iron oxide-carbonate deposit, Northeastern Mozambique, constrained by mineralogy, textures, thermochronometry, and fluid inclusions. Ore Geol. Rev. 2017, 80, 1072-1091. [CrossRef]

10. Dill, H.G. A review of mineral resources in Malawi: With special reference to aluminium variation in mineral deposits. J. Afr. Earth Sci. 2007, 47, 153-173. [CrossRef]

11. Prokopyev, I.R.; Doroshkevich, A.G.; Ponomarchuk, A.V.; Sergeev, S.A. Mineralogy, age and genesis of apatite-dolomite ores at the Seligdar apatite deposit (Central Aldan, Russia). Ore Geol. Rev. 2017, 81, $296-308$. [CrossRef]

12. Trofanenko, J.; William-Jones, A.E.; Simandl, G.J.; Migdisov, A.A. The nature and origin of the REE mineralization in the Wicheeda carbonatite, British Columbia, Canada. Econ. Geol. 2016, 111, 199-223. [CrossRef]

13. Liu, Y.; Zhu, Z.; Chen, C.; Zhang, S.; Sun, X.; Yang, Z.; Liang, W. Geochemical and mineralogical characteristics of weathered ore in the Dalucao REE deposit, Mianning-Dechang REE Belt, western Sichuan Province, southwestern China. Ore Geol. Rev. 2015, 71, 437-456. [CrossRef]

14. Kim, N.; Cheong, A.C.; Yi, K.; Jeong, Y.J.; Koh, S.M. Post-collisional carbonatite-hosted rare earth element mineralization in the Hongcheon area, central Gyeonggi massif, Korea: Ion microprobe monazite U-Th-Pb geochronology and Nd-Sr isotope geochemistry. Ore Geol. Rev. 2016, 79, 78-87. [CrossRef]

15. Ani, T.A.; Sarapaa, O. Geochemistry and mineral phases of REE in Jammi carbonatite veins and fenites, southern end of the Sokli complex, NE Finland. Geochem. Explor. Environ. Anal. 2013, 13, 217-224. [CrossRef]

16. Woodard, J.; Hetherignton, C.J. Carbonatite in a post-collisional tectonic setting: Geochronology and emplacement conditions at Naantali, SW Finland. Precambrian Res. 2014, 240, 94-107. [CrossRef]

17. Basu, S.K.; Bhattacharyya, T. Petrography and mineral chemistry of alkaline-carbonatite complex in Singhbum crustal province, Purulia region, eastern India. J. Geol. Soc. India 2014, 83, 54-70. [CrossRef]

18. Le Bas, M.J.; Ba-bttat, M.A.O.; Taylor, R.N.; Milton, J.A.; Windley, B.F.; Evins, P.M. The carbonatite-marble dykes of Abyan Province, Yemen Republic: The mixing of mantle and crustal carbonate materials revealed by isotope and trace element analysis. Mineral. Petrol. 2004, 82, 105-135. [CrossRef]

19. Liou, J.G.; Zhang, R.V.; Ernst, W.G.; Rumble, D.I.; Maruyama, S. High-pressure minerals from deeply subducted metamorphic rocks. Rev. Mineral. 1998, 37, 33-96. 
20. Wall, F.; Zaitsev, A.N. Rare earth minerals in Kola carbonatites. Phoscorites and Carbonatites from Mantle to Mine: The Key Example of the Kola Alkaline Province. Mineral. Soc. Ser. 2004, 10, 341-373.

21. Poletti, J.E.; Cottle, J.M.; Hagen-Peter, G.A.; Lackey, J.S. Petrochronological constraints on the origin of Mountain Pass ultrapotassic and carbonatite intrusive suite, California. J. Petrol. 2016, 57, 1555-1598. [CrossRef]

22. Decree, S.; Boulvais, P.; Tack, L.; Andre, L.; Baele, J.M. Fluorapatite in carbonatite-related phosphate deposits: The case of the Matongo carbonatite (Burundi). Miner. Deposita 2016, 51, 453-466. [CrossRef]

23. Lazareva, E.V.; Zhmodik, S.M.; Dobretsov, N.L. Main minerals of abnormally high-grade ores of the Tomtor deposit (Arctic Siberia). Russ. Geol. Geophys. 2015, 56, 844-873. [CrossRef]

24. Lottermoser, B.G. Rare-earth element mineralization within the Mt. Weld carbonatite laterite, Western Australia. Lithos 1990, 24, 151-167. [CrossRef]

25. De Toledo, M.C.M.; de Oliveira, S.M.B.; Fontan, F.; Ferrari, V.C.; de Parseval, P. Mineralogia, morfologia e cristaloquímica da monazita de Catalão I (GO, Brasil). Revista Brasileira de Geociências 2004, 34, 135-146.

26. Castor, S.B.; Hedrick, J.B. Rare earth elements. In Industrial Minerals Volume, 7th ed.; Society for Mining, Metallurgy and Exploration Littleton: Englewood, IL, USA, 2006; pp. 769-792.

27. Mariano, A.N.; Mariano, A. Rare earth mining and exploration in North America. Elements 2012, 8, 369-376. [CrossRef]

28. Ribeiro, C.C.; Brod, J.A.; Junqueira-Brod, T.C.; Gaspar, J.C.; Petrinovic, I.A. Mineralogical and field aspects of magma fragmentation deposits in a carbonate-phosphate magma chamber: Evidence from the Catalao I complex, Brazil. J. S. Am. Earth Sci. 2005, 18, 355-369. [CrossRef]

29. Chakhmouradian, A.R.; Mitchell, R.H. Lueshite, pyrochlore and monazite-(Ce) from apatite-dolomite carbonatite, Lesnaya Varaka complex, Kola Peninsula, Russia. Mineral. Mag. 1998, 62, 769-782. [CrossRef]

30. Levinson, A.A. A system of nomenclature for rare earth minerals. Am. Mineral. 1966, 51, 152-158.

31. Nickel, E.H.; Mandarino, J.A. Revised nomenclature for rare-earth-elements minerals. Procedures involving the IMA Commission on New Minerals and Mineral Names, and guidelines on mineral nomenclature. Am. Mineral. 1987, 72, 1031-1042.

32. Graeser, S.; Schwander, H. Gasparite-(Ce) and monazite-(Nd): Two new minerals to the monazite group from the Alps. Schweiz. Mineral. Petrogr. M. 1987, 67, 103-113.

33. Cressey, G.; Wall, F.; Cressey, B.A. Differential REE uptake by sector growth of monazite. Mineral. Mag. 1999, 63, 813-828. [CrossRef]

34. Kim, S.J.; Lee, H.K.; Yin, J.; Park, J.K. Chemistry and origin of monazites from carbonatite dikes in the Hongcheon-Jaeun district, Korea. J. Asian Earth Sci. 2005, 25, 57-67. [CrossRef]

35. Zhu, X.K.; O'Nions, R.K. Monazite chemical composition: Some implications for monazite geochrology. Mineral. Petrol. 1999, 137, 351-363. [CrossRef]

36. Le Bas, M.J.; Keller, J.; Tao, K.J.; Wall, F.; Williams, C.T.; Zhang, P.S. Carbonatite dykes at Bayan Obo, Inner Mongolia, China. Mineral. Petrol. 1992, 46, 195-228. [CrossRef]

37. Smith, M.P.; Henderson, P.; Campbell, L.S. Fractionation of the REE during hydrothermal processes: Constraints from the Bayan Obo Fe-REE-Nb deposit, Inner Mongolia, China. Geochim. Cosmochim. Acta 1999, 64, 3141-3160. [CrossRef]

38. Doroshkevich, A.G.; Ripp, G.; Viladkar, S.G.; Vladykin, N.V. The arshan REE carbonatites, Southwestern Transbaikalia, Russia: Mineralogy, Paragenesis and evolution. Can. Mineral. 2008. [CrossRef]

39. Rose, D. Brabantite, CaTh[PO4 $]_{2}$, a new mineral of the monazite group. N. Jahrb. Mineral.-Monatshefte 1980, 6, 247-257.

40. Laurent, A.T.; Seydoux-Guillaume, A.M.; Duchene, S.; Bingen, B.; Bosse, V.; Datas, L. Sulphate incorporation in monazite lattice and dating the cycle of sulphur in metamorphic belts. Mineral. Petrol. 2016, 171, 94. [CrossRef]

41. Xu, C.; Kynicky, J.; Chakhmouradian, A.R.; Qi, L.; Song, W.L. A unique Mo deposit associated with carbonatites in the Qinling orogenic belt, central China. Lithos 2010, 118, 50-60. [CrossRef]

42. Enkhbayar, D.; Seo, J.; Choi, S.G.; Lee, Y.L.; Batmunkh, E. Mineral chemistry of REE-rich apatite and sulfur-rich monazite from the Mushgai Khudag, alkaline volcanic-plutonic complex, South Mongolia. Int. J. Geosci. 2016, 7, 20-31. [CrossRef] 
43. Wall, F.; Niku-paavola, V.N.; Story, C.; Muller, A.; Jeffries, T. Xenotime-(Y) from carbonatite dykes at Lofdal, Namibia: Unusually low LREE: HREE ratio in carbonatite, and the first dating of xenotime overgrowths on zircon. Can. Mineral. 2008. [CrossRef]

44. Forster, H.J. The chemical composition of REE-Y-Th-U-rich accessory minerals from peraluminous granites of the Erzgebirge-Fichtelgebirge region, Germany. Part I: The monazite-(Ce)—brabantite solid solution series. Am. Mineral. 1998, 83, 259-272. [CrossRef]

45. Förster, H.J.; Harlov, D.E.; Milke, R. Composition and Th-U-total Pb ages of huttonite and thorite from Gillespie's Beach, South Island, New Zealand. Can. Mineral. 2000, 38, 675-684. [CrossRef]

46. Bulakh, A.G.; Nesterov, A.R.; Zaitsev, A.N.; Pilipuk, A.N.; Wall, F.; Kirillov, A.S. Sulfur-containing monazite-(Ce) from late-stage mineral assemblages at the Kandaguba and Vuorijarvi carbonatite complexes, Kola Peninsula, Russia. N. Jahrb. Mineral.-Monatshefte 2000, 5, 217-233.

47. Doroshkevich, A.G.; Ripp, G.S.; Moore, K.R. Genesis of the Khaluta alkaline-basic Ba-Srcarbonatite complex (West Transbaikala, Russia). Mineral. Petrol. 2010, 98, 245-268. [CrossRef]

48. Williams, M.L.; Jercinovic, M.J.; Hetherington, C.J. Microprobe monazite geochronology: Understanding geologic processes by integrating composition and chronology. Annu. Rev. Earth Planet. Sci. 2007, 35, 137-175. [CrossRef]

49. Zhu, X.K.; Sun, J.; Pan, C.X. Sm-Nd isotopic constraints on rare-earth mineralization in the Bayan Obo ore deposit, Inner Mongolia, China. Ore Geol. Rev. 2015, 64, 543-553. [CrossRef]

50. Poitrasson, F.; Chenery, S.; Shepherd, T.J. Electron microprobe and LA-ICP-MS study of monazite hydrothermal alteration: Implications for $\mathrm{U}-\mathrm{Th}-\mathrm{Pb}$ geochronology and nuclear ceramics. Geochim. Cosmochim. Acta 2000, 64, 3283-3297. [CrossRef]

51. Bosse, V.; Boulvais, P.; Gautier, P. Fluid-induced disturbance of the monazite Th-Pb chronometer: In situ dating and element mapping in pegmatites from the Rhodope (Greece, Bulgaria). Chem. Geol. 2009, 261, 286-302.

52. Seydoux-Guillaume, A.M.; Paquette, J.L.; Wiedenbeck, M.; Montel, J.M.; Heinrich, W. Experimental resetting of the U-Th-Pb systems in monazite. Chem. Geol. 2002, 191, 165-181. [CrossRef]

53. Poitrasson, F.; Chenery, S.; Bland, D.J. Contrasted monazite hydrothermal alteration mechanisms and their geochemical implications. Earth Planet. Sci. Lett. 1996, 145, 79-96. [CrossRef]

54. Wang, J.; Tatsumoto, M.; Li, X.; Premo, W.R.; Chao, E.C.T. A precise ${ }^{232} \mathrm{Th}-{ }^{208} \mathrm{~Pb}$ chronology of fine-grained monazite: age of the Bayan Obo REE-Fe-Nb ore deposit, China. Geochim. Cosmochim. Acta 1994, 58, 3155-3169. [CrossRef]

55. Downes, P.J.; Dunkley, D.J.; Fletcher, I.R.; McNaughton, N.J.; Rasmussen, B.; Jaques, A.L.; Verral, M.; Sweetapple, M.T. Zirconolite, zircon and monazite-(Ce) U-Th-Pb age constraints on the emplacement, deformation and alteration history of the Cummins Range carbonatite complex, Halls Creek Orogen, Kimberley region, Western Australia. Mineral. Petrol. 2016, 110, 199-222. [CrossRef]

56. Ferron, G.A. Estimation of the deposition of polydisperse hyroscpic aerosol-particles in the respiratory-track. J. Aerosol Sci. 1991, 6. [CrossRef]

57. Kettanah, Y.A.; Ismail, S.A. Heavy mineral concentrations in the sandstones of Amij formation with particular emphasis on the mineral chemistry and petrogenetic characteristics of monazite, western desert of Iraq. J. Afr. Earth Sci. 2016, 123, 350-369. [CrossRef]

58. Haque, N.; Hughes, A.; Lim, S.; Vernon, C. Rare earth elements: Overview of mining, mineralogy, uses, sustainability and environmental impact. Resources 2014, 3, 614-635. [CrossRef]

59. Aly, M.I.; Masry, B.A.; Gasser, M.S.; Khalifa, N.A.; Daoud, J.A. Extraction of Ce (IV), Yb (III) and Y (III) and recovery of some rare earth elements from Egyptian monazite using CYANEX 923 in kerosene. Int. J. Miner. Process. 2016, 153, 71-79. [CrossRef]

60. Rydberg, J.; Musikas, C.G. Principles and Practices of Solvent Extraction; Marcel Dekker Inc.: New York, NY, USA, 1992.

61. El-Hefny, N.E.; Daoud, J.A. Extraction and separation of thorium (IV) and praseodymium (III) with CYANEX 301 and CYANEX 302 from nitrate medium. J. Radioanal. Nucl. Chem. 2004, 261, 357-363. [CrossRef]

62. El-Hefny, N.E.; El-Nadi, Y.A.; Daoud, J.A. Extraction of lanthanum and samarium from nitrate medium by some commercial organophosphorus extractants. Solvent Extr. Ion Exch. 2007, 25, 1-16. 
63. Masry, B.A.; Aly, M.I.; Khalifa, N.A.; Zikry, A.A.F.; Gasser, M.S.; Daoud, J.A. Liquid-liquid extraction and separation of $\operatorname{Pr}(\mathrm{III}), \mathrm{Nd}$ (III), Sm (III) from nitric acid medium by CYANEX 923 in kerosene. Arab J. Nucl. Sci. Appl. 2015, 48, 1-16.

64. El-Nadi, Y.A.; Daoud, J.A.; Aly, H.F. Modified leaching and extraction of uranium from hydrous oxide cake of Egyptian monazite. Int. J. Miner. Process. 2005, 76, 101-110. [CrossRef]

65. Maes, S.; Zhuang, W.-Q.; Rabaey, K.; Alvarez-Cohen, L.; Hennebel, T. Concomitant leaching and electrochemical extraction of rare earth elements from monazite. Environ. Sci. Technol. 2017, 51, 1654-1661. [CrossRef] [PubMed]

(C) 2017 by the authors. Licensee MDPI, Basel, Switzerland. This article is an open access article distributed under the terms and conditions of the Creative Commons Attribution (CC BY) license (http:/ / creativecommons.org/licenses/by/4.0/). 


\title{
Rare Earth Element Deposits of Alkaline Igneous Rocks
}

\author{
Jaroslav Dostal \\ Department of Geology, Saint Mary's University, 923 Robie Street, Halifax, NS B3H 3C3, Canada; \\ jdostal@smu.ca; Tel.: +1-902-420-5747
}

Received: 9 May 2017; Accepted: 21 July 2017; Published: 25 July 2017

\begin{abstract}
Alkaline igneous complexes host deposits of rare earth elements (REE), which represent one of the most economically important resources of heavy REE and Yttrium (Y). The hosts are differentiated rocks ranging from nepheline syenites and trachytes to peralkaline granites. These complexes usually occur in continental within-plate tectonic settings associated with rifts, faults, or hotspot magmatism. The REE mineralization is found in layered alkaline complexes, granitic stocks, and late-stages dikes and rarely trachytic volcanic and volcaniclastic deposits. The bulk of REE is present in accessory minerals, which can reach percentage levels in mineralized zones. The mineralization contains various REE-bearing minerals that can display complex replacement textures. Main REE minerals present in these deposits are bastnäsite, eudialyte, loparite, gittinsite, xenotime, monazite, zircon, and fergusonite. The parent magmas of alkaline igneous complexes are derived from partial melts of mantle sources. Protracted fractional crystallization of the magma led to an enrichment in REE, particularly in the late stages of magma evolution. The primary magmatic mineralization is commonly overprinted (remobilized and enriched) by late magmatic to hydrothermal fluids. Elevated abundances of $U$ and $T h$ in the deposits make a gamma-ray (radiometric) survey an important exploration tool, but also represent a significant environmental challenge for exploitation.
\end{abstract}

Keywords: rare earth elements; alkaline igneous rocks; deposits; REE-bearing minerals; ore genesis; petrogenesis; exploration

\section{Introduction}

Alkaline igneous rocks host deposits of a variety of rare metals and industrial rocks and minerals. The commodities of special economic importance in these rocks are rare earth elements (REE). In the past 25 years, REE have become essential components of modern technologies. Their demand has increased significantly because of their use in high-technology applications. Among others, they play a vital role in high-strength magnets, mobile phones, flat-screen TVs, lasers, energy-efficient lighting, and superconductors. REE are important in "green technology" where they are used in wind turbines and hybrid gas-electric vehicles (particularly light-weight magnets). In addition, due to the critical role and wide and diverse use of the REE in electronic, military, and environmental applications, there is concern over the security of the supply of these critical elements [1].

The rare earth elements are a group of 16 chemically similar elements including 15 lanthanides and yttrium. The lanthanides are elements with atomic numbers ranging from 57 (Lanthanum) to 71 (Lutetium). They are frequently subdivided into light rare earth elements (LREE) with lower atomic weight i.e., spanning from lanthanum through to europium and the heavy rare earth elements (HREE) ranging from gadolinium (or europium) through to lutetium. Yttrium (atomic number 39) is considered a REE as it has similar chemical and physical properties. Its ionic radius is nearly identical to that of holmium (Ho) and thus is commonly included with HREE. REE exhibit "lanthanide-contraction", the 
steady decrease in the size of the atoms and ions with increase of atomic number from lanthanum to lutetium. Thus, the LREE have larger ionic radii than the HREE and, hence, they behave differently during petrogenetic processes. For example, the HREE generally behave more mantle-compatible than the LREE during partial melting.

The rare earth elements are not as rare in nature as their name implies, in fact, they are relatively abundant in the earth's crust. The crustal abundance of their most abundant element-cerium (Ce) is $\sim 43 \mathrm{ppm}$ compared to copper $\sim 27 \mathrm{ppm}$ and lead $\sim 11 \mathrm{ppm}$ [2]. However, the abundances of individual REE can vary widely, e.g., the crustal abundance of thulium (Tm) is only $\sim 0.28 \mathrm{ppm}$. Compared to LREE, heavy REE are relatively rare in nature but are economically more valuable. The prices of individual REE vary by one or two orders of magnitude.

As the demand for REE has dramatically increased in recent years so have the prices of individual REE, leading to an exploration boom and an increased visibility of REE. They have even become the basis for a bestselling video game. However, economic deposits of REE are rare. Presently, the global production of REE comes from only from a few deposits such as Bayan Obo (China). The REE deposits exist primarily in four geologic environments: carbonatites, alkaline igneous systems, ion-absorption clay deposits, and monazite-bearing placer deposits. This paper focuses on REE deposits associated with alkaline igneous rocks. It reviews and discusses their characteristics and classification, describes examples of the major types of the deposits and comments on their origin and exploration methods. These REE deposits have attracted a great deal of interest in the exploration industry as well as in the geological literature (e.g., [3-6]). They represent one of the most economically important resources of HREE and Y. However, their genesis is still under debate (e.g., [3,6,7]).

\section{Mineralogy}

In nature, REE do not exist individually, as gold often does, but instead they are present together in numerous ore/accessory minerals as either minor or major constituents. REE occur in a wide range of mineral species. There are over 250 minerals which contain REE as important constituents in their chemical formula and crystal structure (Table 1). They are mainly silicates, fluorocarbonates, oxides, and phosphates. These minerals typically comprise the bulk of the REE in a rock. REE are also hosted in minor amounts in the mafic rock-forming minerals such as amphiboles and biotite, where they substitute for major cations of comparable radius and charge.

Table 1. Names and formulae of important rare earth elements (REE)-bearing minerals associated with REE mineralization.

\begin{tabular}{|c|c|c|}
\hline Mineral & Formula & Approx. TREO (wt \%) \\
\hline Allanite & $(\mathrm{Y}, \mathrm{Ln}, \mathrm{Ca})_{2}\left(\mathrm{Al}, \mathrm{Fe}^{3+}\right)_{3}\left(\mathrm{SiO}_{4}\right)_{3}(\mathrm{OH})$ & 39 \\
\hline Apatite & $(\mathrm{Ca}, \mathrm{Ln})_{5}\left(\mathrm{PO}_{4}\right)_{3}(\mathrm{~F}, \mathrm{Cl}, \mathrm{OH})$ & 19 \\
\hline Bastnäsite & $(\mathrm{Ln}, \mathrm{Y})\left(\mathrm{CO}_{3}\right) \mathrm{F}$ & 75 \\
\hline Eudialyte & $\mathrm{Na}_{4}(\mathrm{Ca}, \mathrm{Ln})_{2}\left(\mathrm{Fe}^{2+}, \mathrm{Mn}^{2+}, \mathrm{Y}\right) \mathrm{ZrSi}_{8} \mathrm{O}_{22}(\mathrm{OH}, \mathrm{Cl})_{2}$ & 9 \\
\hline Fergusonite & $(\mathrm{Ln}, \mathrm{Y}) \mathrm{NbO}_{4}$ & 53 \\
\hline Gittinsite & $\mathrm{CaZrSi}_{2} \mathrm{O}_{7}$ & \\
\hline Iimoriite & $\mathrm{Y}_{2}\left(\mathrm{SiO}_{4}\right)\left(\mathrm{CO}_{3}\right)$ & 68 \\
\hline Kainosite & $\mathrm{Ca}_{2}(\mathrm{Y}, \mathrm{Ln})_{2} \mathrm{Si}_{4} \mathrm{O}_{12}\left(\mathrm{CO}_{3}\right) \cdot \mathrm{H}_{2} \mathrm{O}$ & 38 \\
\hline Loparite & $(\mathrm{Ln}, \mathrm{Na}, \mathrm{Ca})(\mathrm{Ti}, \mathrm{Nb}) \mathrm{O}_{3}$ & 30 \\
\hline Monazite & $(\mathrm{Ln}, \mathrm{Th}) \mathrm{PO}_{4}$ & 65 \\
\hline Mosandrite & $(\mathrm{Na}, \mathrm{Ca})_{3} \mathrm{Ca}_{3} \mathrm{Ln}(\mathrm{Ti}, \mathrm{Nb}, \mathrm{Zr})\left(\mathrm{Si}_{2} \mathrm{O}_{7}\right)_{2}(\mathrm{O}, \mathrm{OH}, \mathrm{F})_{4}$ & 33 \\
\hline Parisite & $\mathrm{Ca}(\mathrm{Ln})_{2}\left(\mathrm{CO}_{3}\right)_{3} \mathrm{~F}_{2}$ & 61 \\
\hline Pyrochlore & $(\mathrm{Ca}, \mathrm{Na}, \mathrm{Ln})_{2} \mathrm{Nb}_{2} \mathrm{O}_{6}(\mathrm{OH}, \mathrm{F})$ & \\
\hline Rinkite (rinkolite) & 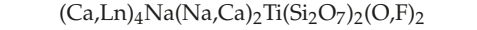 & 20 \\
\hline Steenstrupine & $\mathrm{Na}_{14} \mathrm{Ln}_{6} \mathrm{Mn}_{2} \mathrm{Fe}_{2}(\mathrm{Zr}, \mathrm{Th})\left(\mathrm{Si}_{6} \mathrm{O}_{18}\right)_{2}\left(\mathrm{PO}_{4}\right)_{7} \cdot 3 \mathrm{H}_{2} \mathrm{O}$ & 31 \\
\hline Synchysite & $\mathrm{Ca}(\mathrm{Ln})\left(\mathrm{CO}_{3}\right)_{2} \mathrm{~F}$ & 51 \\
\hline Xenotime & $\mathrm{YPO}_{4}$ & 61 \\
\hline Zircon & $(\mathrm{Zr}, \mathrm{Ln}) \mathrm{SiO}_{4}$ & 4 \\
\hline
\end{tabular}

Ln-lanthanides; TREO—oxides of lanthanides and Yttrium (Y); Estimates of TREO content are based on Webmineral composition (www.webmineral.com). 
REE-bearing minerals tend to be dominated by either LREE or HREE, although each REE can be present. In some mineralized zones, the abundances of REE-bearing accessory (ore) minerals can reach $>10 \mathrm{vol} \%$. In alkaline igneous complexes, mineralization is commonly composed of a variety of REE-bearing minerals, which can exhibit complex replacement textures in part due to late magmatic to hydrothermal overprinting of the primary mineralogy, commonly producing pseudomorphs of pre-existing phases. However, there are only a relatively small number of REE minerals, which can be economically exploited. They include bastnäsite, monazite, xenotime, synchysite, loparite, eudialyte and parasite (Table 1). Overall, the bulk of resources is mostly associated with three REE-rich minerals: bastnäsite, monazite and xenotime (e.g., [3,4]). Bastnäsite and monazite are dominated by LREE whereas xenotime is the main source of HREE and Y (Figure 1). Many other accessory/ore minerals are either sparse or it is difficult to extract REE from them on a commercial scale. In alkaline igneous rocks, the grain size of the ore minerals in REE mineralization varies from coarse grained (commonly cumulate phases in the nepheline syenitic complexes) to fine grained in volcanic rocks and replacement textures.

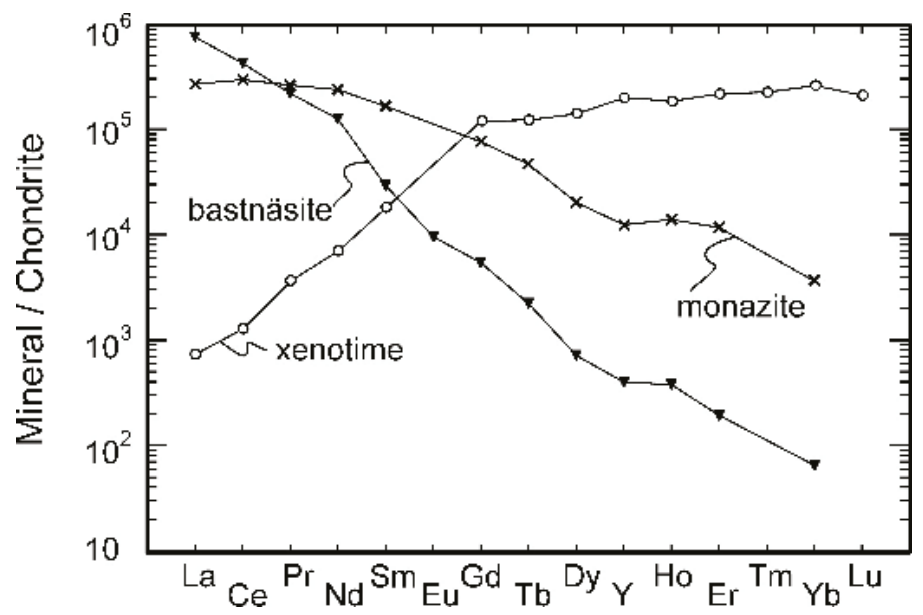

Figure 1. Chondrite-normalized REE (lanthanides and $Y$ ) patterns of minerals that are the major components of REE ores: monazite, xenotime [8] and bastnäsite [9]. Note that Yttrium is plotted as a pseudo-lanthanide between Dy and Ho. Normalizing values are after Sun and McDonough [10].

\section{Alkaline Igneous Rocks}

The generally accepted definition of the "alkaline rocks" means a primary enrichment of $\mathrm{Na}_{2} \mathrm{O}$ and $\mathrm{K}_{2} \mathrm{O}$ in a rock of a given $\mathrm{SiO}_{2}$ content. Alkaline igneous rocks are so enriched in alkalis that they contain abundant Na- and K-bearing minerals (such as feldspathoids, alkali pyroxenes and alkali amphiboles) which are not commonly present in other rock types. Na-rich amphiboles (e.g., arfvedsonite and riebeckite) and Na-rich pyroxenes (e.g., aegirine) are dominant mafic minerals in these rocks rather than common Fe-Mg silicates. Likewise, feldspars may be replaced or accompanied by feldspathoids such as nepheline, sodalite, leucite, or cancrinite. However, there are some ambiguities when using the term alkaline for the felsic rocks. To resolve this problem, petrologists revived the name "peralkaline" to specify important chemical characteristics of the alkaline rocks even for the felsic types. The peralkaline rocks have a higher molecular proportion of combined sodium and potassium than aluminum (Figure 2) and their CIPW norms typically contain acmite and Na-metasilicate. 


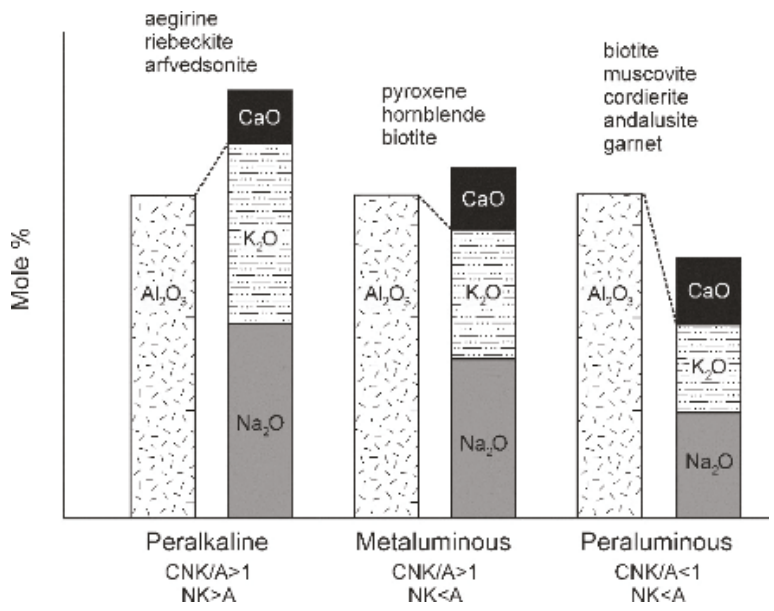

Figure 2. Classification of felsic rocks based upon molecular proportions of $\mathrm{Al}_{2} \mathrm{O}_{3}, \mathrm{CaO}, \mathrm{Na}_{2} \mathrm{O}$ and $\mathrm{K}_{2} \mathrm{O}$. Common non-quartz-feldspathic minerals for each type are shown. Vertical axis is schematic. $\mathrm{CNK}=\mathrm{CaO}+\mathrm{Na}_{2} \mathrm{O}+\mathrm{K}_{2} \mathrm{O} ; \mathrm{NK}=\mathrm{Na}_{2} \mathrm{O}+\mathrm{K}_{2} \mathrm{O} ; \mathrm{A}=\mathrm{Al}_{2} \mathrm{O}_{3}$.

The peralkalinity reflects not only the mineralogy and major element composition of the rocks but it has an effect on the distribution of several rare metals. The peralkaline rocks are very high in REE, uranium, thorium and high-field strength elements (HFSE) such as zirconium, niobium and tantalum as well as halogens ( $\mathrm{Cl}$ and $\mathrm{F})$. In fact, these rocks, particularly of nepheline syenitic and granitic composition, can host REE deposits, which are commonly enriched in yttrium and HREE (Figure 3). The Nb-Y-F type of pegmatites [11], which may host Be, REE, Th, U and Zr mineralization, has also been correlated with the peralkaline granites. Alkaline rocks including peralkaline ones, are commonly found in anorogenic and within-plate tectonic settings, mostly in continental rift and/or crustal extension zones [3].

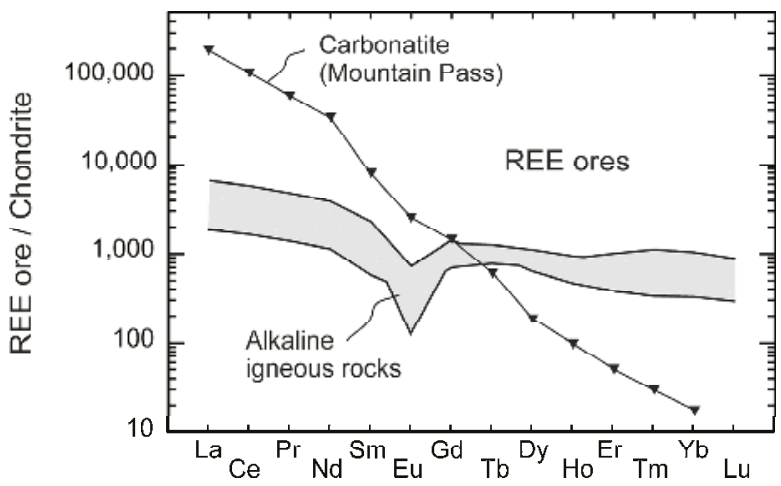

Figure 3. Chondrite-normalized REE patterns of an average ore of Mountain Pass (California, USA), a major carbonatite-hosted REE deposit [1,9] and the range of the average ores of the REE deposits associated with alkaline igneous rocks (Thor Lake, Strange Lake, Kipawa, Norra Kärr, and Bokan). The data are from Hatch [12,13]. Normalizing values are after Sun and McDonough [10]. 


\section{Rare Earth Element Deposits}

Economically, the REE mineralization and deposits include two separate types: LREE and HREE deposits. Most LREE are produced from carbonatite deposits (Figure 4) including Bayan Obo in China and Mountain Pass in California (currently shut down). It is likely that these large deposits will satisfy, for the medium-term future, the needs for LREE, including neodymium. Monazite-bearing placer deposits were important REE sources in the past. In fact, several decades ago, placer deposits met most of the world's REE needs. From beach/placer deposits, LREE-rich monazite can still be recovered as a by-product during the exploitation of the Ti-rich minerals. However, monazite contains significant amounts of uranium and thorium and thus these deposits are presently out of favour due to environmental concerns (high radioactivity). Additionally, carbonatite and monazite-rich placer deposits contain only trace amounts of the HREE. Thus, these deposits do not provide a sufficient supply of HREE. Ion-adsorption clay deposits in southern China (referred to as "south China clays") are currently the world's main source of HREE. These deposits have low contents in REE but they are economic because the REE can be easily extracted from them. The second significant HREE sources are alkaline rock-hosted deposits containing HREE and $\mathrm{Y}$ as their primary product or coproduct (Figures 3 and 4). The deposits containing HREE generally tend to be lower grade than the LREE deposits. However, the HREE, based on unit value, can be more valuable and their low grade deposits may still be economically exploitable.

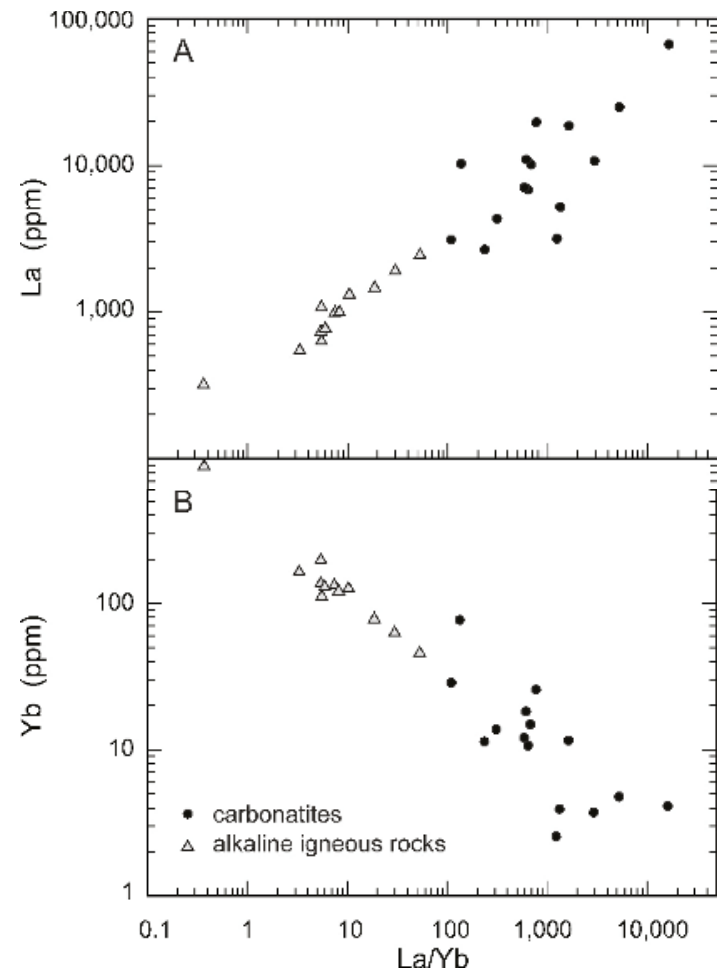

Figure 4. The variations of $\mathrm{La}$ and $\mathrm{Yb}(\mathrm{ppm})$ relative to $\mathrm{La} / \mathrm{Yb}$ ratios in REE ores of carbonatites and alkaline igneous rocks. Most data reflect the average grades of the REE ores in the deposits and exploration projects reported by Hatch $[12,13]$. 
There is no shortage of prospective REE deposits, many of which have been discovered and explored before the recent collapse of REE prices. The factors to determine whether prospects and discoveries are viable include not only the grade (REE concentrations) and tonnage (size) of REE ore in a deposit but also other essential technical and economic criteria including amendable mining and refining. The REE are chemically very similar to each other, occur together, and thus it is difficult to separate individual elements from each other. The separation and purification of individual REE require complex processing, which can be rather expensive. There are also numerous social and environmental issues (e.g., energy, water, land use, potential pollution and socioeconomic issues) to be solved as well as a market issue (i.e., to find an off-taker that will buy the product).

One of the principal environmental challenges of these deposits is the presence of radioactive elements (Th and $\mathrm{U}$ ) that are usually associated with them. On the other hand, the acid-drainage hazards of these deposits are low due to the very small contents of potentially acid-generating sulfides as well as the presence of feldspars and even subordinate amounts of carbonates (buffer).

\section{Rare Earth Element Deposits of Alkaline Igneous Rocks}

The locations of several prominent REE deposits and advanced exploration targets which are hosted in alkaline (peralkaline) igneous rocks are shown in Figure 5. In addition to REE, some of these deposits contain economically important amounts of other rare metals, including HFSE such as $\mathrm{Zr}, \mathrm{Nb}$, Ta and $\mathrm{Hf}$ as well as $\mathrm{U}$ and $\mathrm{Th}$. The calculated ore reserves as well as the average grades of the deposits are given in Table 2 and a brief description of the most important deposits is given below. The age of the mineralized alkaline complexes ranges from Neoarchean/Paleoproterozoic to Mesozoic (e.g., [3]) with a significant peak during the Mesoproterozoic (1000-1460 Ma). Similarly, large carbonatite-hosted REE deposits are also of Proterozoic age including the Mountain Pass ( 1400 Ma), Bayan Obo ( 1300 Ma) and Palabora (South Africa; 2050 Ma).

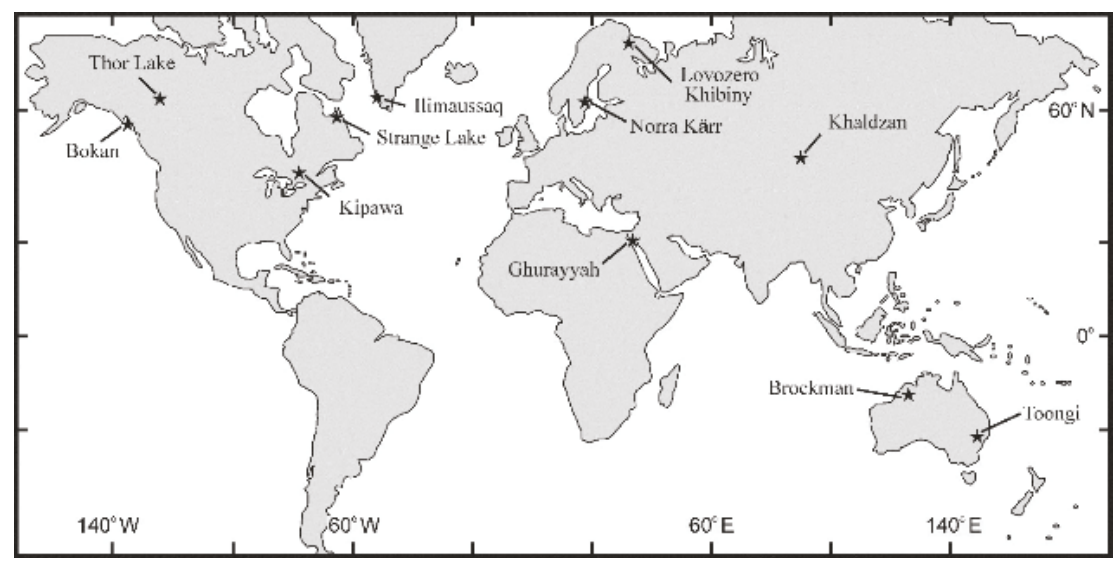

Figure 5. World map showing the locations of major REE deposits hosted in alkaline/peralkaline igneous rocks.

The REE deposits of alkaline complexes are typically hosted by nepheline syenites, peralkaline granites (including pegmatites) and, less commonly, peralkaline felsic volcanic rocks. In all these deposits, the mineralization is closely related to the crystallization of magma, particularly to its late fractions. 
Table 2. Tonnage and ore grade of selected rare earth elements (REE) deposits hosted by alkaline igneous rocks.

\begin{tabular}{|c|c|c|c|c|}
\hline Deposit & Ore Reserves (Mt) & TREO Ore Grade (wt \%) & TREO Reserves (Mt) & HREO/TREO (\%) \\
\hline \multicolumn{5}{|c|}{ Thor Lake (Nechalacho), Canada } \\
\hline Basal zone & 125.7 & 1.43 & 1.799 & 20.9 \\
\hline Upper zone & 177.7 & 1.32 & 2.353 & 10.0 \\
\hline \multicolumn{5}{|l|}{ Ilimaussaq, Greenland } \\
\hline Kvanefjeld deposit & 619.0 & 1.06 & 6.547 & 11.8 \\
\hline Sørensen deposit & 242.0 & 1.10 & 2.667 & 11.7 \\
\hline Zone 3 deposit & 95.3 & 1.16 & 1.106 & 12.1 \\
\hline Kipawa, Canada & 27.1 & 0.40 & 0.107 & 36.2 \\
\hline Norra Kärr, Sweden & 58.1 & 0.59 & 0.343 & 50.3 \\
\hline \multicolumn{5}{|l|}{ Strange Lake, Canada } \\
\hline Enriched zone & 20.0 & 1.44 & 0.288 & 49.7 \\
\hline Granite zone & 472.5 & 0.87 & 4.118 & 36.5 \\
\hline Bokan, Alaska, USA & 4.9 & 0.61 & 0.030 & 40.1 \\
\hline Toongi, Australia & 73.2 & 0.89 & 0.651 & 23.3 \\
\hline Brockman, Australia & 36.2 & 0.21 & 0.076 & 85.8 \\
\hline
\end{tabular}

Data from Hatch (2014). Abbreviations: Mt—million metric tons. TREO-oxides of lanthanides and Y; HREO — oxides of heavy REE and Y. Recent data are not available for some deposits discussed in the text including Lovozero, Khibiny, Khaldzan-Buregtey, and Ghurayyah.

The REE deposits comprise three distinct groups, based on their host rocks. The first deposit type is hosted by nepheline syenitic rocks of the large layered alkaline intrusions. The host rocks show textures suggestive of crystal accumulation where the REE mineralization occurs in layers containing mineral cumulates that are rich in REE-bearing minerals. Cumulate textures indicate that the initial REE enrichment was due to magmatic processes and the ore-bearing layers represent cumulate layers within a magma chamber. The thickness of the ore horizons is variable ranging from $\sim 0.5 \mathrm{~m}$ to more than $100 \mathrm{~m}$. The REE minerals accumulated at the highly fractionated parts of the intrusions. These deposits (Figure 5) include Ilimaussaq (Greenland), Lovozero and Khibiny (Kola Peninsula, Russia), Thor Lake/Nechalacho (NWT, Canada), Kipawa (Canada), and Norra Kärr (Sweden).

The second group encompasses the deposits associated with peralkaline granites such as mineralization in pegmatites (e.g., Strange Lake, Quebec-Labrador, Canada), felsic dikes (e.g., Bokan Mountain, southeastern Alaska, USA) and minor highly fractionated intrusions where the REE-bearing minerals occur mostly disseminated and do not show any features of crystal accumulation (e.g., Khaldzan-Buregtey, western Mongolia; Ghurayyah, Saudi Arabia). The third type is associated with peralkaline felsic volcanic rocks, mainly trachytes containing disseminations of very fine-grained REE-bearing minerals. An example of these relatively rare deposits is Toongi (Dubbo Zirconia) and Brockman/Hastings, both in Australia (Figure 5). Although a number of alkaline rock-hosted REE deposits are in advanced stages of exploration, the only REE deposits that are actively mined at present are those on the Kola Peninsula in Russia.

\section{Exploration}

The REE deposits are spatially and genetically associated with alkaline igneous suites and thus exploration is targeting these rock types, which occur in continental anorogenic and within-plate tectonic settings and typically are along zones of rifting and/or faulting. In layered intrusions, the mineralization mostly appears in the more evolved parts of the complex. The elevated concentrations of the elements: REE, HFSE, $\mathrm{U}, \mathrm{Th}$, and F compared to regional background abundances are useful reconnaissance indicators for geochemical exploration (e.g., [3,7]). Other geologic exploration indicators are alteration halos and heavy minerals. The presence of abundant resistate REE-rich minerals in heavy mineral concentrates of stream sediments or soils is a useful exploration tool (e.g., [3,7]). These indicator minerals include zircon, monazite, and xenotime. Some alkaline igneous intrusions are surrounded by alteration halos due to the escape alkali-rich magmatic fluids into surrounding country rocks producing alkali metasomatism. This process converts the host rock minerals to an assemblage dominated by alkali-rich minerals, particularly albite. 
Ground and airborne geophysical exploration methods are "standard" exploration tools for the REE deposits hosted in alkaline rocks. An enrichment of the deposits in $U$ and Th, and hence their radioactivity, makes radiometric surveys very effective exploration methods. Many known REE deposits such as Bokan, Thor Lake, Kipawa, and Greenland were discovered during exploration for uranium deposits. In addition, magnetic and gravity surveys are also used to locate alkaline igneous complexes and their deposits.

\section{Origin of Alkaline Rocks and REE Mineralization}

Host nepheline syenites, syenites, and peralkaline granites are commonly considered to be generated by extensive fractional crystallization of alkaline basaltic magmas. In turn, these melts are usually assumed to be derived by a small degree of partial melting of lithospheric mantle metasomatically enriched in HFSE, REE, Th, $\mathrm{U}$, and halogens rather than a primitive mantle source [14]. The high abundances of halogens indicate the presence of amphibole or phlogopite in the mantle source. Chakhmouradin and Zaitsev [4] infer that the bulk of the REE in the source was either in amphibole or in accessory minerals.

High concentrations of REE and associated metals in alkaline felsic rocks are partially due to prolonged fractional crystallization. These elements are strongly mantle-incompatible and thus are distinctly enriched in the residual melts during crystallization. Furthermore, the presence of volatiles, particularly fluorine, extends the range of crystallization to low temperatures [15] and suppresses crystallization of HFSE- and REE-bearing minerals until the last stages of crystallization when the magma becomes fluid-saturated and enriched in rare metals [16]. The rare metal mineralization in both nepheline syenites and peralkaline granites typically occurs in the highly evolved parts of the respective intrusions.

The origin of the REE mineralization in the alkaline rocks is still debated, in particular whether the mineralization is magmatic, hydrothermal, or a combination of both (e.g., [3,7]. However, more recent studies (e.g., $[6,17,18])$ imply that both magmatic and hydrothermal processes contributed to the origin of the REE deposits. The primary magmatic mineralization was overprinted by late magmatic to hydrothermal fluids rich in REE, HFSE, Th, and $U$ that remobilized and enriched the original mineralization during multiple metasomatic events and re-deposited them as secondary phases (e.g., [6,7,19]). Large layered intrusions, such as Lovozero, which do not show any sign of crustal input, are also hydrothermally altered. This suggests that fluids are of an orthomagmatic origin and released during the last stages of magma evolution i.e., derived from the magma itself. Crustal-derived fluids could have played a role in some of the smaller layered intrusions. However, the relative contributions of both processes are variable. In some cases, where REE minerals-rich layers form part of cumulate sequences, magmatic processes might have been predominant, while in other examples, hydrothermal processes have played a more dominant role in the upgrading of initial magmatic concentrations.

\section{Examples of REE Deposits in Alkaline Rocks}

Several prominent deposits associated with alkaline rocks (Table 2; Figure 5) are briefly described below. They include deposits hosted by (a) nepheline syenites: Ilimaussaq (Greenland), Lovozero and Khibiny (Russia) and Thor Lake (Nechalacho; Northwest Territories, Canada), (b) peralkaline granites: Strange Lake (Quebec-Labrador, Canada) and Bokan Mountain (Alaska, USA), and (c) trachytic volcanic rocks: Toongi (Dubbo Zirconia) and Brockman (Hastings) both from Australia.

\subsection{Ilimaussaq, Southern Greenland}

The 1.13 Ga-old Ilimaussaq complex, which contains several economically exploitable deposits (Table 2) of REE, zirconium, niobium, and uranium, is one of the best-known alkaline intrusions in the world. It is the famous mineralogical locality of several minerals, which are unique to this intrusion. In addition, the complex is the type locality for 33 minerals including eudialyte, sodalite, 
and arfvedsonite [20,21]. The ellipsoid-shaped layered complex is $\sim 17 \mathrm{~km}$ in length and $8 \mathrm{~km}$ in width with an exposed vertical thickness of about $1700 \mathrm{~m}[20,21]$. It is composed of nepheline syenites, syenites, and peralkaline granites that contain eudialyte-rich cumulate layers. The magmatic evolution of the complex ended with the emplacement of hydrothermal veins rich in $\mathrm{Zr}$, $\mathrm{U}$, and REE minerals. The main REE-bearing minerals of the complex are eudialyte, rinkite, and steenstrupine (Table 1). The complex was already explored for uranium in the 1950's to 1970's.

\subsection{Lovozero and Khibiny, Russia}

The 370 Ma old Lovozero complex of the Kola Peninsula of Russia (Figure 5), which intruded into Precambrian rocks, is one of the largest alkaline layered intrusions in the world. It is an oval-shaped layered sheet-like lopolith, which extends over an area of about $650 \mathrm{~km}^{2}$ and continues to a depth of several kilometers [22,23]. This complex, composed of various nepheline syenitic cumulates, is rich in REE, yttrium, zirconium, niobium, tantalum, and phosphorus, which occur in eudialyte, loparite, and apatite. Loparite has been mined for about 50 years with an annual production of $\sim 30,000$ tons of loparite concentrate containing about $34 \%$ REE [17].

The Khibina complex (Figure 5) is another nepheline syenitic cumulate intrusion that may be genetically related to the nearby Lovozero massif. It has a similar age and forms an elliptical-shaped ring complex, which is about $40 \mathrm{~km}$ long and covers an area of $>1300 \mathrm{~km}^{2}$. The complex hosts several nepheline-apatite deposits containing $\sim 15 \mathrm{wt} \% \mathrm{P}_{2} \mathrm{O}_{5}$ and $0.4 \mathrm{wt} \%$ oxides of rare earth elements [19]. The ore is typically made up of $\sim 60-90 \%$ apatite and has been mined for phosphate over 80 years. The apatite was formed by accumulation during fractional crystallization of the magma.

\subsection{Thor Lake (Nechalacho), Northwest Territories, Canada}

This Early Proterozoic deposit, located $\sim 100 \mathrm{~km}$ south of Yellowknife, along the southern margin of the Slave Province of the Canadian Shield, is hosted in a layered alkaline complex dated at $\sim 2100 \mathrm{Ma}$, and it contains a variety of nepheline syenites. Many rocks have cumulate textures. The intrusion, which is only locally exposed on surface, was drilled over an area of $\sim 5 \mathrm{~km}^{2}$. The mineralization occurs primarily within two tabular cumulate zones about 15-60 m thick (Table 2). The primary ore minerals are zircon and eudialyte, which were subsequently pseudomorphed by orthomagmatic hydrothermal fluids. At present, the major ore minerals are zircon, fergusonite, allanite, synchysite, and bastnäsite [24].

\subsection{Strange Lake, Eastern Canada}

The Strange Lake deposit is hosted by a circular ring complex composed of peralkaline granites dated at $1240 \mathrm{Ma}$ [25], and straddles the boundary between the Canadian Provinces of Quebec and Newfoundland and Labrador (Figure 5). The complex intrudes the Rae Province of the Canadian Shield. It is about $8 \mathrm{~km}$ in diameter and consists of three intrusive phases. There are two types (Table 2) of mineralization: (1) low-grade disseminated in granites of the intermediate intrusive phase and (2) high-grade mineralization hosted by pegmatites (the youngest phase). The dominant REE-bearing mineral is gittinsite, but other important minerals include bastnäsite, monazite, kainosite, thorite, pyrochlore, and gadolinite. Some of these minerals are of secondary origin as hydrothermal overprinting played a significant role during the formation of the ore [17].

\subsection{Bokan Mountain, Alaska, USA}

The Jurassic (177 Ma) Bokan Mountain complex, located at the southern part of the Prince of Wales Island (southeastern Alaska), is a circular intrusion of about $3 \mathrm{~km}$ in diameter. This concentrically zoned body consists of a core made up of arfvedsonite granite and an outer zone composed predominantly of aegirine granite. The major REE mineralization occur in clusters of subparallel mineralized dikes and metasomatically enriched alteration halos (albite rich) associated with shear zones [18,26]. The mineralized dikes occur both within the complex as well as in the surrounding Paleozoic granites. 
The largest cluster is in a zone which is about $50 \mathrm{~m}$ wide and $>2 \mathrm{~km}$ long. The REE-bearing minerals are xenotime, fergusonite, monazoite, bastnäsite, synchysite, zircon, immoriite, and kainosite and many of them are secondary occurring as replacements of pre-existing REE-bearing minerals by late-magmatic to post-magmatic fluids. The complex also hosts a U-Th deposit, which was intermittently mined between 1957 and 1971. The mine produced about 85,000 $\mathrm{t}$ of ore with a grade of $\sim 1 \mathrm{wt} \% \mathrm{U}_{3} \mathrm{O}_{8}$ and $3 \mathrm{wt} \% \mathrm{ThO}_{2}$. The main ore minerals are thorite and uraninite. The Th-U deposit is a mineralized pipe-shaped alteration zone which measures about $24 \mathrm{~m}$ in width. Both thorium-uranium and REE deposits are of magmato-hydrothermal origin where the primary magmatic mineralization was overprinted and upgraded by late-stage orthomagmatic hydrothermal fluids.

\subsection{Toongi (Dubbo Zirconia), Australia}

This deposit is located about $400 \mathrm{~km}$ NW of Sydney in New South Wales and is hosted by a nearly vertical trachyte plug $\sim 900 \mathrm{~m}$ long and $600 \mathrm{~m}$ wide. The plug is a part of the Mesozoic alkaline intraplate volcanic complex $\sim 15-20 \mathrm{~km}$ in diameter. It is composed of Jurassic (184 Ma) peralkaline trachyte with microphenocrysts of K-feldspar, plagioclase, and aegirine enclosed in a fine-grained matrix containing accessory ore minerals. The ore minerals are very fine grained (typically $<20 \mu \mathrm{m}$ ) and include eudialyte ( $\mathrm{Zr}, \mathrm{Y}, \mathrm{HREE})$, niobite ( $\mathrm{Nb}$ and $\mathrm{Ta}$ ), and bastnäsite (REE), which are relatively uniformly dispersed throughout the plug $[27,28]$. Ore minerals are considered to represent primary interstitial phases which were subsequently enriched by late magmatic to hydrothermal fluids.

\subsection{Brockman (Hastings), Australia}

The Brockman (or Hastings) deposit is located $\sim 18 \mathrm{~km}$ southeast of Hall Creek, Western Australia. The mineralization is hosted by fluorite-bearing felsic volcaniclastic rocks known as the "Niobium tuff" $[29,30]$. It is the lowermost unit of the early Proterozoic Brockman volcanic suite, a sequence composed of trachytic and rhyolitic lavas, volcaniclastic units, and subvolcanic intrusions. The "Niobium tuff" is 5 to $35 \mathrm{~m}$ thick and over $3.5 \mathrm{~km}$ long with volcanic detritus dated at $\sim 1870 \mathrm{Ma}[29,30]$. The rock unit, which is distinctly enriched in HFSE and HREE, contains very fine grained $(<20 \mu \mathrm{m})$ and disseminated ore minerals including zircon, bastnäsite, parasite, and synchysite. Like in other REE deposits, the mineralization is considered to be the result of extensive fractional crystallization, where late-stage fluorine-rich fluids that enriched the rare metal concentrations have overprinted the primary ore minerals.

\section{Conclusions}

Alkaline igneous rocks are distinctly enriched in sodium and potassium and contain Na- and/or K-rich minerals such as feldspathoids, alkali pyroxenes, and alkali amphiboles. Some of these rocks are peralkaline, which have a higher molecular proportion of combined $\mathrm{K}$ and $\mathrm{Na}$ than $\mathrm{Al}$, and can contain economically important mineralization of REE. These rocks occur in continental anorogenic or within-plate tectonic settings where they are related to rifting and/or extensional tectonics.

The mineralization is commonly related to the late stages of the magma evolution. The bulk of the REE occurs in ore minerals which locally show complex replacement textures. REE-bearing ore minerals include fluorocarbonates, phosphates, silicates, and oxides. The REE mineralization is typically accompanied by elevated concentrations of $U$ and $T h$, which make gamma-ray (radiometric) surveys important exploration tools, but also represent a significant environmental challenge during exploitation of the deposits.

The host nepheline syenitic and peralkaline granitic rocks are typically formed by fractional crystallization from parent magmas that were in turn derived from a lithospheric mantle source metasomatically enriched in REE. The deposits typically represent two periods of mineralization. The first, primary magmatic period is associated with crystallization of highly fractionated magma rich in REE. The minerals of this period are commonly overprinted during the second period by late magmatic to hydrothermal fluids that remobilized and enriched the primary ore during multiple 
metasomatic events. These deposits represent one of the most economically important resources of HREE and $Y$.

Acknowledgments: The research was supported by U.S. Geological Survey Mineral Resources External Research Program and the Natural Sciences and Engineering Research Council of Canada. Thanks are due to Daniel Müller and an anonymous referee for constructive reviews which improved the manuscript.

Conflicts of Interest: The author declares no conflict of interest.

\section{References}

1. Long, K.R.; Van Gosen, B.S.; Foley, N.K.; Cordier, D. The Principal Rare Earth Elements Deposits of the United States-A Summary of Domestic Deposits and A Global Perspective; U.S. Geological Survey, Scientific Investigations Report 2010-5220; 2010; 96p. Available online: http://pubs.usgs.gov/sir/2010/ 5220/ (accessed on 24 July 2017).

2. Rudnick, R.L.; Gao, S. Composition of the continental crust. In The Crust Treatise on Geochemistry; Rudnick, R.L., Ed.; Elsevier: Amsterdam, The Netherlands, 2003; Volume 3, pp. 1-64.

3. Richardson, D.G.; Birkett, T.C. Peralkaline rock-associated rare metals. In The Geology of North America; Eckstrand, O.R., Sinclair, W.D., Thorpe, R.I., Eds.; Geological Society of America: Boulder, CO, USA, 1996; Volume P-1, pp. 523-540.

4. Chakhmouradian, A.R.; Zaitsev, A.N. Rare earth mineralization in igneous rocks: Sources and processes. Elements 2012, 8, 347-353. [CrossRef]

5. Mariano, A.N.; Mariano, A., Jr. Rare earth elements: Rare earth mining and exploration in North America. Elements 2012, 8, 369-376. [CrossRef]

6. Dostal, J. Rare metal deposits associated with alkaline/peralkaline igneous rocks. Rev. Econ. Geol. 2016, 18, 33-54.

7. Verplanck, P.L.; Van Gosen, B.S.; Seal, R.R.; McCafferty, A.E. A Deposit Model for Carbonatite and Alkaline Intrusion-Related Rare Earth Element Deposits; Scientific Investigations Report 2010-5070-J; U.S. Geological Survey: Reston, VA, USA, 2014; p. 58.

8. Förster, H.J.; Tischendorf, G.; Trumbull, R.B.; Gottesmann, B. Late-collisional granites in the Variscan Erzgebirge, Germany. J. Petrol. 1999, 40, 1613-1645. [CrossRef]

9. Castor, S.B. The Mountain Pass rare-earth carbonatite and associated ultrapotassic rocks, California. Can. Mineral. 2008, 46, 779-806. [CrossRef]

10. Sun, S.S.; McDonough, W.F. Chemical and isotopic systematics of oceanic basalts: Implications for mantle composition and processes. Geol. Soc. Lond. Spec. Publ. 1989, 42, 313-345. [CrossRef]

11. Černy, P.; Ercit, T.S. Classification of granitic pegmatites revisited. Can. Mineral. 2005, 43, 2005-2026. [CrossRef]

12. Hatch, G.P. TMR Advanced Rare-Earth Projects Index. Technology Metal Research. October 2012. Available online: http:/ / www.techmetalsresearch.com/metrics-indices/tmr-advanced-rare-earth-projects-index/ (accessed on 24 July 2017).

13. Hatch, G.P. TMR Advanced Rare-Earth Projects Index. Technology Metal Research. March 2014. Available online: http:/ / www.techmetalsresearch.com/metrics-indices/tmr-advanced-rare-earth-projectsindex/ (accessed on 24 July 2017).

14. Pilet, S.; Baker, M.B.; Stolper, E.M. Metasomatized lithosphere and the origin of alkaline lavas. Science 2008, 320, 916-919. [CrossRef] [PubMed]

15. Markl, G.; Marks, M.; Schwinn, G.; Sommer, H. Phase equilibrium constraints on intensive crystallization parameters of the Ilmaussaq Complex, South Greenland. J. Petrol. 2001, 42, 2231-2258. [CrossRef]

16. Halter, W.; Webster, J.D. The magmatic to hydrothermal transition and its bearing on ore-forming systems. Chem. Geol. 2004, 210, 1-6. [CrossRef]

17. Salvi, S.; Williams-Jones, A.E. Alkaline granite-syenite deposits. In Rare-Element Geochemistry and Mineral Deposits; Linnen, R.L., Samson, I.M., Eds.; Short Course Notes; Geological Association of Canada: St. John's, NL, Canada, 2005; Volume 17, pp. 315-341. 
18. Dostal, J.; Kontak, D.J.; Karl, S.M. The Early Jurassic Bokan Mountain peralkaline granitic complex (southeastern Alaska): Geochemistry, petrogenesis and rare-metal mineralization. Lithos 2014, 202-203, 395-412. [CrossRef]

19. Linnen, R.L.; Samson, I.M.; Williams-Jones, A.E.; Chakhmouradian, A.R. Geochemistry of the rare-earth element, Nb, Ta, Hf and Zr deposits. Treatise on Geochem. 2014, 13, 543-568.

20. Sørensen, H. Brief introduction to the geology of the Ilímaussaq alkaline complex, South Greenland, and its exploration history. In The Ilimaussaq Alkaline Complex, South Greenland: Status of Mineralogical Research with New Results; Sørensen, H., Ed.; Geology of Greenland Survey Bulletin (190); GEUS: Copenhagen, Denmark, 2001; pp. 7-23.

21. Sørenson, H. The Ilimaussaq alkaline Complex, South Greenland-An Overview of 200 Years of Research and an Outlook; Museum Tusculanum Press: Copenhagen, Denmark, 2006.

22. Kogarko, L.N.; Lahaye, Y.; Brey, G.P. Plume-related mantle source of super-large rare metal deposits from the Lovozero and Khibina massifs on the Kola Peninsula, Eastern part of Baltic Shield: Sr, Nd and Hf isotopic systematics. Mineral. Petrol. 2010, 98, 197-208. [CrossRef]

23. Kogarko, L.N.; Williams, C.T.; Woolley, A.R. Chemical evolution and petrogenetic implications of loparite in layered, agpaitic Lovozero complex, Kola Peninsula, Russia. Mineral. Petrol. 2002, 74, 1-24.

24. Sheard, E.R.; Williams-Jones, A.E.; Heoligmann, M.; Pederson, C.; Trueman, D.L. Controls on the concentration of zirconium, niobium, and the rare earth elements in the Thor Lake Rare metal deposit, Northwest Territories, Canada. Econ. Geol. 2012, 107, 81-104. [CrossRef]

25. Miller, R.R.; Heaman, L.M.; Birkett, T.C. U-Pb zircon age of the Strange Lake peralkaline complex: Implications for Mesoproterozoic peralkaline magmatism in north-central Labrador. Precambr. Res. 1997, 81, 67-82. [CrossRef]

26. Dostal, J.; Karl, S.M.; Keppie, J.D.; Kontak, D.J.; Shellnutt, J.G. Bokan Mountain peralkaline granitic complex, Alexander terrane (southeastern Alaska): Evidence for Early Jurassic rifting prior to accretion with North America. Can. J. Earth Sci. 2013, 50, 678-691. [CrossRef]

27. Chalmers, I. The Toongi Rare Metal and Rare Earth Deposit-Dubbo Zirconia Project. In Proceedings of 34th International Geological Congress, Brisbane, Australia, 5-10 August 2012; Available online: http:/ / alkaneresources.com.au/pdf/presentations/20120808.pdf (accessed on 24 July 2017).

28. Spandler, C.; Morris, C. Geology and genesis of the Toongi rare metal (Zr, Hf, Ta, Y, and REE) deposit, NSW Australia and implication for rare metal mineralization in peralkaline igneous rocks. Contrib. Mineral. Petrol. 2016, 171, 104-128. [CrossRef]

29. Taylor, W.R.; Esslemont, G.; Sun, S.S. Geology of the volcanic-hosted Brockman rare-metals deposit, Halls Cree Mobile Zone, northwest Australia. II. Geochemistry and petrogenesis of the Brockman volcanics. Mineral. Petrol. 1995, 52, 231-255. [CrossRef]

30. Taylor, W.R.; Page, R.W.; Esslemont, G.; Rock, N.M.S.; Chalmers, D.I. Geology of the volcanic-hosted Brockman rare-metals deposit, Halls Cree Mobile Zone, northwest Australia. I. Volcanic environment, geochronology and petrography the Brockman volcanics. Mineral. Petrol. 1995, 52, 209-230. [CrossRef]

(C) 2017 by the author. Licensee MDPI, Basel, Switzerland. This article is an open access article distributed under the terms and conditions of the Creative Commons Attribution (CC BY) license (http:/ / creativecommons.org/licenses/by/4.0/). 


\title{
Article \\ Sources of Extraterrestrial Rare Earth Elements: To the Moon and Beyond
}

\author{
Claire L. McLeod ${ }^{1, *}$ and Mark. P. S. Krekeler ${ }^{2}$ \\ 1 Department of Geology and Environmental Earth Sciences, 203 Shideler Hall, Miami University, \\ Oxford, OH 45056, USA \\ 2 Department of Geology and Environmental Earth Science, Miami University-Hamilton, Hamilton, \\ OH 45011, USA; krekelmp@miamioh.edu \\ * Correspondence: mcleodcl@miamioh.edu; Tel.: 513-529-9662; Fax: 513-529-1542
}

Received: 10 June 2017; Accepted: 18 August 2017; Published: 23 August 2017

\begin{abstract}
The resource budget of Earth is limited. Rare-earth elements (REEs) are used across the world by society on a daily basis yet several of these elements have $<2500$ years of reserves left, based on current demand, mining operations, and technologies. With an increasing population, exploration of potential extraterrestrial REE resources is inevitable, with the Earth's Moon being a logical first target. Following lunar differentiation at $\sim 4.50-4.45 \mathrm{Ga}$, a late-stage (after $\sim 99 \%$ solidification) residual liquid enriched in Potassium (K), Rare-earth elements (REE), and Phosphorus (P), (or "KREEP") formed. Today, the KREEP-rich region underlies the Oceanus Procellarum and Imbrium Basin region on the lunar near-side (the Procellarum KREEP Terrain, PKT) and has been tentatively estimated at preserving $2.2 \times 10^{8} \mathrm{~km}^{3}$ of KREEP-rich lithologies. The majority of lunar samples (Apollo, Luna, or meteoritic samples) contain REE-bearing minerals as trace phases, e.g., apatite and/or merrillite, with merrillite potentially contributing up to $3 \%$ of the PKT. Other lunar REE-bearing lunar phases include monazite, yittrobetafite (up to 94,500 ppm yttrium), and tranquillityite (up to $4.6 \mathrm{wt} \%$ yttrium, up to $0.25 \mathrm{wt} \%$ neodymium), however, lunar sample REE abundances are low compared to terrestrial ores. At present, there is no geological, mineralogical, or chemical evidence to support REEs being present on the Moon in concentrations that would permit their classification as ores. However, the PKT region has not yet been mapped at high resolution, and certainly has the potential to yield higher REE concentrations at local scales $(<10 \mathrm{~s}$ of kms). Future lunar exploration and mapping efforts may therefore reveal new REE deposits. Beyond the Moon, Mars and other extraterrestrial materials are host to REEs in apatite, chevkinite-perrierite, merrillite, whitlockite, and xenotime. These phases are relatively minor components of the meteorites studied to date, constituting $<0.6 \%$ of the total sample. Nonetheless, they dominate a samples REE budget with their abundances typically 1-2 orders of magnitude enriched relative to their host rock. As with the Moon, though phases which host REEs have been identified, no extraterrestrial REE resource, or ore, has been identified yet. At present extraterrestrial materials are therefore not suitable REE-mining targets. However, they are host to other resources that will likely be fundamental to the future of space exploration and support the development of in situ resource utilization, for example: metals ( $\mathrm{Fe}, \mathrm{Al}, \mathrm{Mg}$, PGEs) and water.
\end{abstract}

Keywords: rare-earth elements; Moon; extraterrestrial; space; Mars; meteorites

\section{Introduction}

"Space may be vast, but many of the most valuable resources-especially those convenient to Earth-are limited. Our Moon may be one of the most promising sites for mining, energy capture, and spaceship refueling, but a limited amount of useable land exists, with an even more limited quantity of useable water. The problem is not limited to the Moon. Every resource is limited. The question then 
is who, if anyone, should have the right to the riches of space? Space is an international zone, and so is, in a sense, the heritage of all humanity." [1]

The rare-earth elements (REEs) are a group of transition metals which include the lanthanide series of the periodic table (lanthanum to lutetium), in addition to scandium and yttrium. Despite the nomenclature, they are not rare with cerium (Ce) being the 25th most abundant element on Earth [2] at an average value of $60 \mathrm{ppm}$. This is compared to $<1 \mathrm{ppm}$ for the least abundant REEs (thulium (Tm) and lutetium (Lu)) [3]. In addition, the occurrence of REEs is often associated with U-Th mineralization, where uranium ore deposits often contain a significant concentration of REEs [4]. The REEs are as abundant as tin, lead, and cobalt in Earth's lithosphere, and are more abundant that gold and silver [5]. However, they are dispersed throughout the rock record and only exist in concentrated, economically viable, deposits in certain areas of the world with the largest accumulation of REEs being found in the Bayan Obo deposit in China [6].

The REEs are widely used on Earth by humankind on a daily basis. They are integral components of smart phones, computer monitors, flash drives, lightbulbs, camera lenses, catalysts, and magnets, and are fundamental to many military-based technologies. However, as of 2012, REEs had been produced from less than 20 minerals with bastnäsite $\left(\mathrm{REECO}_{3}(\mathrm{~F}, \mathrm{OH})\right)$, monazite $\left((\mathrm{REE}, \mathrm{Th}, \mathrm{Ca}, \mathrm{Sr})(\mathrm{P}, \mathrm{Si}, \mathrm{S}) \mathrm{O}_{4}\right)$, xenotime $\left((\mathrm{REE}, \mathrm{Zr})(\mathrm{P}, \mathrm{Si}) \mathrm{O}_{4}\right)$, loparite $\left((\mathrm{Na}, \mathrm{REE}, \mathrm{Ca})(\mathrm{Ti}, \mathrm{Nb}) \mathrm{O}_{3}\right)$, parisite $\left(\mathrm{CaREE}_{2}\left(\mathrm{CO}_{3}\right)_{3}(\mathrm{~F}, \mathrm{OH})_{2}\right)$, and Al-clays, accounting for the majority of REE production [2]. From the USGS Mineral Commodity Summary in 2014 [7], Earth's REE reserves totaled 140 million tonnes, with almost half of those resources in China (55 million tonnes) and the United States (13 million tonnes). Figure 1 summarizes the years of REE reserves left on Earth based on recent mining practices and technologies, alongside their concentration in Earth's crust.

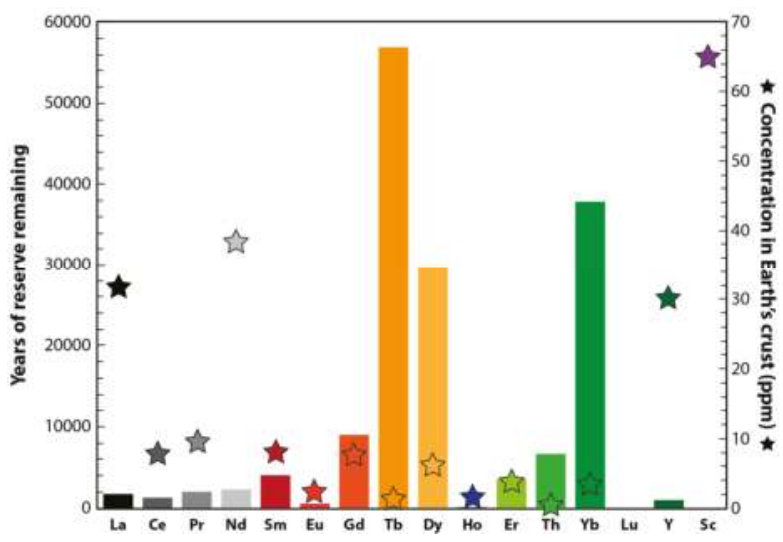

Figure 1. Estimated reserves of selected rare-earth elements (REEs: $x$-axis) in years (shown on left hand $y$-axis) and their abundance in the Earth's crust (right hand $y$-axis). The colored bar represents the number of years that element has left as a reserve. The corresponding star symbol illustrates the concentration of that element in the Earth's crust (ppm). Data from [4].

Most critical are the reserves of Europium (Eu), the only rare earth metal to have $<1000$ years remaining as a resource. It is used daily, in conjunction with phosphors, to generate red in televisions which use cathode ray tubes, and is a common component in compact fluorescent bulbs [8]. Also from Figure 1, lanthanum (La, which is three times more abundant than lead (Pb) in Earth's crust; [8]), Ce, praseodymium (Pr), neodymium (Nd), holmium (Ho), and yttrium (Y) all have reserves $<2500$ years. Respectively, these elements are used in mischmetal for spark effects in movies (La), in the oxide form as an abrasive for polishing glass (Ce); generating the green color in fake cubic-zirconia peridot $(\mathrm{Pr})$, in high power magnets (Nd), in magnetic resonance imaging (MRI) machines to concentrate 
the magnetic field (Ho), and in barium copper oxide powders for use in superconductors ( $Y$; $[8])$. Figure 2 summarizes the short term (within 5 years), and medium term (5-15 years), criticality of REEs (in addition to cobalt (Co), gallium (Ga) indium (In), lithium ( $\mathrm{Li})$, and tellurium $(\mathrm{Te})$ ).

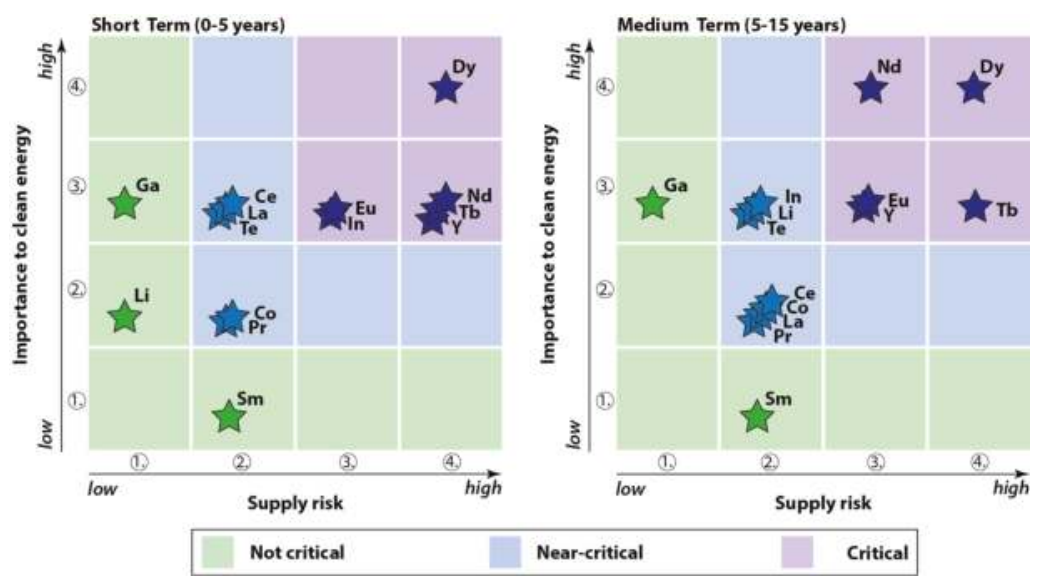

Figure 2. Figure modified from the United States Department of Energy [9] highlighting the criticality of rare-earth metals, starting in 2015. The star symbols for each element are colored to correspond with the criticality index in the legend. Note that the REEs, particularly dysprosium (Dy), Eu, Nd, terbium $(\mathrm{Tb})$, and $\mathrm{Y}$, are associated with both a high supply risk, and are considered highly valuable to clean energy within the next 13 years.

The following elements are both highly valuable to clean energy, and are experiencing a high supply risk, both in the short term, and medium term: $\mathrm{Dy}, \mathrm{Eu}, \mathrm{Nd}, \mathrm{Tb}$, and $\mathrm{Y}$. Of all the elements shown in Figure 2, $\mathrm{Li}$ is the only element to change from a lower criticality index (not critical), to a higher criticality index (near critical). This change is associated with the projected increase in the use of lithium-ion batteries in vehicles (and hence an increased importance to clean energy; U.S. Department of Energy (DOE) [9]). As noted in the DOE report, market dynamics and increased research and investment in alternatives will ultimately contribute to the criticality of these elements in the future.

\section{The Criticality of REEs in Our Society}

The REEs have thus emerged as a critical materials group over the past 20 years and the uses, market demands, and holders of these materials have played integral roles in the growth of the global economy over this time period [10]. Specifically, REEs are deemed critical to the growing global green economy [9]. Generally, the demand for REEs ultimately relates to the unique orbital structures and transitions of electrons in orbitals of the REEs such as transitions involving intra- $4 \mathrm{f}$ or $4 \mathrm{f}-5 \mathrm{~d}$ that produce fluorescent light emissions, oxidation state changes in reactions or the magnetic properties of REEs. In a 2011 USGS report, REE applications market sectors were classified as metallurgy neodymium-iron-boron magnets catalysts glass including polishing and additives and other uses and detailed consumption in these areas are based on available reviewed 2008 data [11]. These general resource sectors have permeated nearly every aspect of the global economy with a wide variety of uses.

The REEs are also a critical material in clean energy technologies and within major areas of utility including wind turbines, lighting, magnets, and vehicles [9]. Several industry sectors are heavily dependent on the REEs owing to their magnetic, electrical, and optical properties. These industry sectors include but are not limited to defense, power generation, energy efficiency, catalysis, medicine [10]. 
The advent of REE based magnets in the 1960s revolutionized the utility of wind power [12]. Wind turbines utilize REE magnets in their dynamos. The REEs functionally provide stronger magnetic field in smaller volumes compared to their traditional Fe-based counterparts [12]. Thus, wind turbines have become an increasing important renewable energy source in the last 10 years and this technological evolution has been directly driven by REEs [9].

In addition, the REEs are used in a multitude of defense technologies in the US and are considered a strategic resource. Examples of some specific defense uses of REEs include motors for disk drives in numerous aircraft, land vehicles and command and control facilities, optical technologies including laser weapon detections and countermeasures and other equipment, satellite communications, radar and sonar components, as well as other technologies [13]. The REEs are also well recognized catalysts. For example, Ce is well recognized as an oxidative catalyst $[14,15]$ and Eu has been used as a catalyst in molecular synthesis $[16,17]$. This is an area of use that is expected to grow as catalysis is directly tied to energy efficiency [9].

In a recent review, luminescence, medical imaging, and therapeutic applications were highlighted as the most important microcrystal and nanocrystal application areas [18]. In the context of medical technology, optical imaging, X-ray tomography (CT), positron emission tomography (PET) and magnetic resonance imaging (MRI) techniques (as stated earlier) can be enhanced by use of REE nanoparticles typically involving $\mathrm{Dy}, \mathrm{Gd}, \mathrm{Tb}$, and $\mathrm{Eu}$ [18]. REE nanoparticles have also been investigated and used in the treatment of cancer in photodynamic therapies and photothermal therapies, in addition to the simple delivery of chemotherapy components [18].

All of the above uses are dependent on essentially mined resources. Recycling of REEs is challenging and not practiced widely [11]. What recycling does occur is primarily from fluorescent lamps, batteries, and magnets but is of limited scope, estimated at perhaps only 250 tons [19]. Identifying new REE resources, whilst continuing to improve and expand recycling efforts, is an absolute requirement for the continued utilization of REEs in the modern consumer economy and the emerging global green economy.

The Earth's population is projected to reach 8.5 billion by 2030 [20] yet the mining industry is currently downsizing [21]. This temporary decline is predominantly associated with quotas that are being placed on REE exportation, and a reduction of illegal mining operations by the Chinese government [4]. However, material and energy resources on Earth are ultimately limited hence sustaining our reliance on raw materials will likely require investment in, and utilization of, extraterrestrial resources. A first natural (and logical) step is the investigation and exploitation of resources on our Moon [22].

\section{Earth's Moon: Missions to Our Nearest Neighbor}

Study of Earth's Moon began several centuries ago in 1609 as Galileo made the first telescopic observations of Earth's nearest neighbor in space [23]. Observations, exploration, and the study of Moon formation and evolution have continued ever since the first spacecraft landed on the lunar surface in 1959 as part of the Soviet Union's Space Program (Luna 2). The most recent lunar landing occurred in 2013 through the China National Space Administration (the Chang'e 3 mission) and a follow-up mission, Chang'e 5, is scheduled to be launched November 2017. This will be the first lunar sample return mission since 1976 (Luna 24).

The sources of raw materials, on which the human race depends, have to date originated from one planet, Earth. Advances in space exploration technology however have the potential to expand our "closed planetary economy" to include extraterrestrial resources [24]. Efforts to map and characterize the lunar surface have been extensive, and are ongoing: SMART-1 (European Space Agency, 2004); Kaguya (Japan, 2007); Chang'e-1 (China, 2007); Chandrayaan-1 (India, 2008); Lunar Reconnaissance Orbiter (LRO, United States of America, 2009); Chang'e-2 (China, 2010); the Gravity Recovery and Interior Laboratory (GRAIL, United States of America, 2012); and Chang'e-3 (which included a lander and rover, the first lunar landing since 1976, China, 2013). Yet, not since the mission of 
the Luna 24 mission in August 1976, has a spacecraft designed for sample return landed on the Moon, and not since December 1972 has humankind set foot on the lunar surface (Apollo 17) [25]. The Earth's Moon has previously been described as an "Earth-orbiting Space Station" [26] on which exist, natural resources that have the potential to be practically, and sustainably, used by humanity. The Earth's Moon is fundamental to advancing our understanding of the evolution of terrestrial planets and is the only other Solar System object for which a rich data set of geology, mineralogy, petrology, geochemistry, geochronology, and internal architecture exists. The exploration of the Moon and its resources is a fundamental step in furthering the exploration of our Solar System [26,27]. The potential use of Earth's Moon as a resource is thus an important discussion to have within the context of sustaining human society and the planning of future space investigations. If humankind is to one day live on extraterrestrial bodies, such as the Moon or Mars, then the dependency on Earth as a resource source needs to be minimized, and the development of in situ resource dependency maximized [28]. The establishment of a base station on the lunar surface may one day be required in order to facilitate humankinds' exploration of our Solar System to, and beyond, to Mars. This would require a self-sufficient operational base where fundamental life support materials existed, fuel components were available, and construction materials were accessible (e.g., [29-31]).

A decade ago, 14 space agencies developed a vision for human space exploration and established a network through which this could be communicated, and ultimately achieved [32]. This is The Global Exploration Strategy: The Framework for Coordination. The first target is the nearest one in our Solar System, the Earth's Moon. The Earth's Moon has been the focus of geoscientific and cosmoscientific investigations for decades. It is a window into early Solar System processes which were fundamental to the geological and chemical evolution of Earth, and it provides insights into the evolution of planetary bodies (e.g., [33-59]).

Numerous scientific, technological, socio-economical, and political rationales exist that justify our study and exploration of Earth's nearest neighbor in space, but in order to maximize the potential of the Moon as a resource, stakeholders and nations will have to effectively and sustainably collaborate [22]. In September of 2007, at the Wired Nextfest in Los Angeles, the Google Lunar XPRIZE (GLXP) was announced. This space competition, organized by XPRIZE is sponsored by Google, and offers $\$ 30$ million USD in funding to privately funded teams who land a robot on the lunar surface. At the time of writing, four teams remain, each of which have secured launch contracts. These include: Moon Express (USA, launch contract with Rocket Lab); Synergy Moon (International, launch contract with Interorbital Systems); Hakuto (Japan, launch contract with the Indian Space Research Organization (ISRO)); and Team Indus (India, launch contract with ISRO). The prize is awarded for (1) successfully placing a spacecraft on the surface of the Moon; (2) traveling 500 meters across the lunar surface; and (3) transmitting high-definition images and video feed back to Earth [60]. Each team is scheduled to launch by the end of 2017. Not since 1976 has a spacecraft landed on the Moon. This year, that is scheduled to change several times over with the success of the above missions in addition to the November Chang'e-5 launch. The USA team, Moon Express is to date, the only company to publicly announce that they aim to mine REEs on the Moon. Moon Express proposes to construct a lunar railroad on "Earth's eighth continent", process ores using robots, and return the extracted elements back to Earth [61]. Prior to this, they must claim the Google Lunar XPRIZE. Only "then the second or third mission can involve bringing things back from the Moon" (Naveen Jain, co-founder and CEO of Moon Express, speaking to Susan Caminiti of CNBC in 2014 [62]).

In addition, the current Lunar CATALYST (Cargo Transportation and Landing by Soft Touchdown) initiative, managed by NASAs Human Exploration and Operations Mission Directorate, is collaborating with three commercial companies in order to develop technologies that could be used to transport materials to the lunar surface (https: / / www.nasa.gov/lunarcatalyst/). Through partnerships with Astrobotic Technologies, Masten Space Systems, and Moon Express, these collaborative efforts aim to result in the successful landing of commercial robotic spacecrafts on the Moon with "resource prospecting" being one of the capabilities that would be supported. As of 2017, NASA had issued a 
second Request for Information regarding the "availability of small payloads that could be delivered to the Moon as early as the 2017-2020 timeframe" (https://www.fbo.gov/index?s=opportunity\&mode= form\&id=cbcd56e6afbd7dfad1ef9cd0fb52b6f7\&tab=core\&tabmode=list).

From past, present, and future remote sensing missions, to Apollo and Luna missions of the 1960s and 1970s, to the future plans for robotic landers on the lunar surface, there is no doubt of the interest and investment being placed on the exploration and potential utilization of our nearest neighbor in space.

\section{Lunar Differentiation}

\subsection{The Lunar Magma Ocean}

Today, the Moon is a differentiated planetary object with a core, mantle, and crust (Figure 3a). The present day internal architecture of the Moon has been constrained to: an upper mantle from 60 to $400 \mathrm{~km}$; a mantle transition zone from 400 to $800 \mathrm{~km}$; a lower mantle from to (at least) $1100 \mathrm{~km}$; a fluid outer core (350 km radius); and a solid inner core (160 km radius, Figure 3a: [63-65]). In the absence of plate tectonics, the lunar crust and mantle have remained physically separate for the past $\sim 4$ billion years $[64,66]$. In order to better evaluate potential lunar resources, the geochemical differentiation processes associated with lunar formation and evolution need to be understood [67].

Fundamental to recent interpretations of lunar evolution, is the Lunar Magma Ocean (LMO) model. Following formation of the Moon, c. 70-110 Myrs after the onset of Solar System formation through a giant impact between proto-Earth and an impacting body (Mars-sized Theia), molten material rapidly accumulated and began to solidify [33-35,68]. Previous studies have investigated the extent to which the Moon was initially molten with models ranging from scenarios in which the initial LMO depth was as shallow as $400 \mathrm{~km} \mathrm{[41],} \mathrm{molten} \mathrm{to} 1000 \mathrm{~km}$ [69], to a scenario where the whole Moon was initially molten [50].

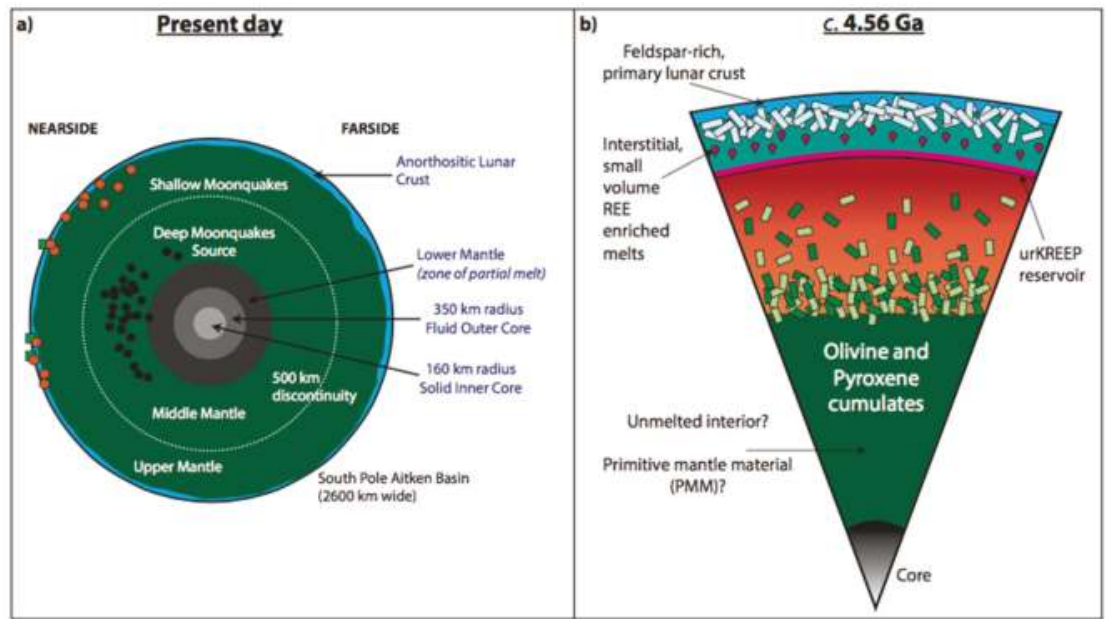

Figure 3. (a) Schematic cross section of the lunar interior (modified from [64,70]). Results from the GRAIL mission reveal an average crustal thickness of between 34 and $43 \mathrm{~km}$, with impact basins exhibiting thicknesses near $0 \mathrm{~km}$ (the Moscoviense and Crisium basins [71]). The Moon's largest and oldest basin is the $\sim 13 \mathrm{~km}$ deep South Pole Aitken Basin located on the lunar far side. From GRAIL, crustal thicknesses here are estimated at $<5 \mathrm{~km}$ [71,72]. Moonquakes have been detected at both shallow (50-220 km) and deep (800-1000 km) depths within the lunar mantle. Seismic velocities have identified a distinct discontinuity at $\sim 500 \mathrm{~km}$, which has been associated with a phase change from spinel to garnet 
(300-500 km, e.g., [73]). One hypothesis has been that this $\sim 500 \mathrm{~km}$ discontinuity represents the extent of the mare basalt mantle source region; (b) Schematic summary of the LMO model showing dense settling out of early formed olivine and pyroxene. These cumulates sink to the lunar interior and form the source regions to the younger mare basalts. Following 75-80\% LMO crystallization, Ca-rich plagioclase feldspar is a liquidus phase, and being less dense than the surrounding mantle, forms an anorthitic flotation crust. Following $99 \%$ solidification, the ITEs are concentrated in the last remaining dregs of the LMO and form the urKREEP reservoir from which KREEP-like signatures are inferred to originate. The depth to which an LMO on a primordial Moon existed has been debated for decades (whole Moon vs. partial Moon melting). For a summary of previous models, see [70].

The presence of magma oceans (or magmaspheres) on early formed planetary bodies has been debated and widely discussed throughout the planetary science community for decades $[39,41,51,74]$. The concept of a MO on an early formed Moon has established the context in which the geochemical and geochronological history of Earth's nearest neighbor in space is evaluated today. Simply, the widely-accepted sequence for crystallization of the LMO is the following: olivine $\rightarrow$ orthopyroxene \pm olivine $\rightarrow$ olivine $\rightarrow$ clinopyroxene \pm plagioclase $\rightarrow$ clinopyroxene + plagioclase $\rightarrow$ clinopyroxene + plagioclase + ilmenite [75]. As a young Moon solidified, the first phases to fractionally crystallize out (olivine and pyroxene, \pm Fe-Ti oxides) were denser than the surrounding magma and sank towards the lunar interior (Figure $3 \mathrm{~b}$ ). Following $\sim 75-80 \%$ solidification, low-density plagioclase feldspar became a liquidus phase and buoyantly rose to form an anorthitic feldspathic flotation crust (Figure 3b). This sequence of differentiation events accounts for the old anorthositic lunar highlands samples (c. 4.57-4.34 Ga; summary of ages presented in [55]), which have been interpreted as representing primary plagioclase-rich flotation crust, and the younger mare basalts (the majority at c. 4.0-2.0 Ga: [76], with a recent study suggesting magmatism may have occurred as recently as 100 Ma: [77]), which were derived from source reservoirs in the lunar interior which had experienced previous melt (plagioclase) extraction (olivine and pyroxene cumulates, Figure $3 b$ ). This petrogenetic model for the anorthositic lunar highlands, and mare basalts, is further supported by the positive europium anomalies in the lunar highlands samples, complementary negative europium anomalies in the mare basalts, and the absence of plagioclase on the mare basalt liquidus [78-84].

At $\sim 99 \%$ solid (e.g., $[51,69,85,86])$, the remaining LMO liquids would have been relatively enriched in incompatible trace elements (ITEs), as these elements are not easily incorporated into the crystal structures of the major silicate phases: olivine, pyroxene ( $\pm \mathrm{Fe}-\mathrm{Ti}$ oxides), and plagioclase feldspar. These elements would have included potassium $(\mathrm{K})$, the REEs, and phosphorous ( $\mathrm{P}$, collectively referred to as "KREEP": Figure $3 \mathrm{~b}$ ) and are hypothesized to have formed a late-stage reservoir between the solidifying lunar mantle and crust. This reservoir, a residuum from LMO differentiation, is referred to as urKREEP, with the Germanic prefix "ur" meaning primeval [85]. The source of KREEP signatures in lunar rocks has thus been associated with an urKREEP origin.

It is noted here that there is currently debate regarding both the timing, and the duration, of LMO crystallization. Ages of lunar crustal rocks characterized by high proportions of anorthitic feldspar, and thus interpreted as representing primary lunar crust, range from 4.57 to $4.36 \mathrm{Ga}$ ([87,88] for a review see [55]) while models of solidification range from 10 to 200 Myrs depending on whether tidal eating is invoked $([69,89]$ respectively). Ages associated with formation of the KREEP reservoir range from $4.48 \mathrm{Ga}$ (from Apollo 14 zircons) [90] to $4.36 \mathrm{Ga}$ (Lu-Hf isotopic systematics on KREEP basalts) [91].

\subsection{Lunar Mineralogy}

Mineralogically, the Moon is very simple with only four major phases: olivine $\left((\mathrm{Mg}, \mathrm{Fe})_{2} \mathrm{SiO}_{4}\right)$; pyroxene $\left((\mathrm{Ca}, \mathrm{Mg}, \mathrm{Fe})_{2} \mathrm{Si}_{2} \mathrm{O}_{6}\right)$; plagioclase $\left(\mathrm{Ca}_{2} \mathrm{Al}_{2} \mathrm{Si}_{2} \mathrm{O}_{8}\right)$; and ilmenite $\left(\mathrm{FeTiO}_{3}\right)[42,92,93]$. These phases dominate the Moon's major lithologies, the anorthositic lunar highlands, and the mare basalts (Figure 4). Figure 4a shows the lunar nearside with the location of the six Apollo landing sites also shown, note that Apollo 16 was the only mission which targeted the lunar highlands. The other 
missions targeted various regions of the lunar maria. Figure $4 \mathrm{~b}$ shows a characteristic lunar highlands sample, 60025, dominated by plagioclase feldspar. Figure 4c shows a typical mare basalt, characterized by pyroxene, plagioclase, ilmenite, and olivine. This particular sample is highly vesiculated and has been determined to originate from depths $>250 \mathrm{~km}$ in the lunar mantle [94].

Minor phases also present throughout the lunar (Apollo, Luna, and meteorite) sample collection include apatite $\left(\mathrm{Ca}_{5}\left(\mathrm{PO}_{4}\right)(\mathrm{F}, \mathrm{Cl})\right)$; baddeleyite $\left(\mathrm{ZrO}_{2}\right)$; chromite-ulvöspinel $\left(\mathrm{FeCr}_{2} \mathrm{O}_{4}-\mathrm{Fe}_{2} \mathrm{TiO}_{4}\right)$; iron $(\mathrm{Fe}(\mathrm{Ni}, \mathrm{Co}))$; k-feldspar $\left((\mathrm{K}, \mathrm{Ba}) \mathrm{AlSi}_{3} \mathrm{O}_{8}\right)$; merrillite $\left(\left(\mathrm{Ca}_{3}\right)\left(\mathrm{PO}_{4}\right)_{2}\right)$; pleonaste $\left((\mathrm{Fe}, \mathrm{Mg})(\mathrm{Al}, \mathrm{Cr})_{2} \mathrm{O}_{4}\right)$; rutile $\left(\mathrm{TiO}_{2}\right)$; silica $\left(\mathrm{SiO}_{2}\right)$; ternary feldspar $\left((\mathrm{Ca}, \mathrm{Na}, \mathrm{K}) \mathrm{AlSi}_{3} \mathrm{O}_{8}\right)$; troilite $(\mathrm{FeS})$; zircon $\left(\mathrm{ZrSiO}_{4}\right)$; and zirkelite-zirconolite $\left((\mathrm{Ca}, \mathrm{Fe})(\mathrm{Zr}, \mathrm{Y}, \mathrm{Ti})_{2} \mathrm{O}_{7}\right)$ [93]. Several other minerals enriched in refractory elements, are also found on the Moon (some uniquely), including: dysanalyte $(\mathrm{Ca}, \mathrm{Fe})(\mathrm{Ti}, \mathrm{REE}) \mathrm{O}_{3}$, thorite $\left(\mathrm{ThSiO}_{4}\right)$; titanite $\left(\mathrm{CaTiSiO}_{5}\right)$; tranquillityite $\left(\mathrm{Fe}_{8}(\mathrm{Zr} \mathrm{Y}) \mathrm{Ti}_{3} \mathrm{Si}_{3} \mathrm{O}_{24}\right)$; yittrobetafite $\left.(\mathrm{Ca}, \mathrm{Y}, \mathrm{U}, \mathrm{Th}, \mathrm{Pb}, \mathrm{REE})_{2}(\mathrm{Ti}, \mathrm{Nb})_{2} \mathrm{O}_{7}\right)$; zirconolite $\left(\mathrm{CaZrTi}_{2} \mathrm{O}_{7}\right)$; and zirkelite $\left((\mathrm{Ca}, \mathrm{Th}, \mathrm{Ce}) \mathrm{Zr}(\mathrm{Ti}, \mathrm{Nb})_{2} \mathrm{O}_{7}\right)[95,96]$.
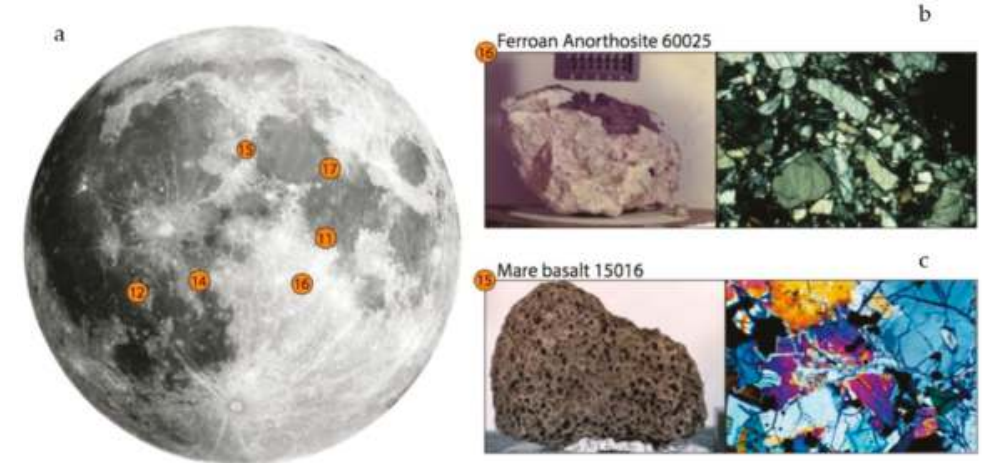

Figure 4. (a) Near side of the Earth's Moon with Apollo landing sites shown. The majority of landing sites targeted the lunar mare (dark regions); (b) Left hand image shows a hand sample of 60025, a Ferroan Anorthosite. Right hand image shows a thin section photomicrograph of 60025, characterized by $70-98 \%$ plagioclase feldspar $[85,97,98]$. (c) Left hand image shows a hand sample of 15016, a vesiculated olivine-normative basalt. Right hand image shows a thin section photomicrograph of 15016 , characterized by olivine (6-10\%), pyroxene (59-67\%), plagioclase (21-27\%), ilmenite $(6 \%)$, and $<1 \%$ total of chromite, ulvösplniel, and mesostasis [99-101]. All images are available from the NASA Lunar Sample Atlas [102].

\section{Lunar Resources}

\subsection{The KREEP Source}

Following study of the returned Apollo samples, an easily identifiable, and geochemically distinguishable, component within the lunar sample collection was apparent. This unique signature is associated with elevated REE, K and P (or, KREEP) [102]. Historically, the origin of the KREEP component in lunar lithologies has been debated with two principal theories regarding its petrogenesis proposed throughout the literature: (1) Partial melting of the solidified lunar interior following LMO crystallization and (2) extreme fractional crystallization of the primordial LMO (Figure 3b). In [103], partial melting was concluded as not being responsible for the observed abundances of ITEs in the KREEP-rich lithologies. This was due to inconsistencies in the behavior of elements in partial melting models, most notably the large fractionations between La and Lu (which is not observed). Instead, covariation of $\sim 20$ ITEs which cover a 10-fold range of abundances in samples which are derived from spatially distinct sample sites throughout the Apollo collection, further support their derivation from a common lunar geochemical reservoir ([103]; Figure 3b). The uniformity in ITE enrichment, consistent LREE/HREE ratios (light rare-earth elements/heavy rare-earth elements), and similarity 
in ${ }^{143} \mathrm{Nd} /{ }^{144} \mathrm{Nd}$ isotopic signatures is therefore inconsistent with local-scale partial melting and subsequent fractional crystallization, but consistent with derivation from a reservoir formed during LMO differentiation (urKREEP) [104].

Today, KREEP-rich lithologies are demonstrably associated with relative enrichments in thorium (Th) and uranium (U) (Figure 5).

Evaluation of the distribution of KREEP-rich lithologies is therefore possible through gamma ray mapping $[105,106]$. Results from the gamma ray spectrometer onboard the orbiting Lunar Prospector orbiting spacecraft revealed a concentrated distribution of Th(and KREEP)-rich lithologies in the northern hemisphere of the near-side of the Moon (Figure 5). This distribution is also associated with the region known as Oceanus Procellarum, and the Imbrium Basin, and is now widely referred to as the Procellarum KREEP Terrain (or the PKT) [107]. The concentration of KREEP-rich lithologies on the near-side of the Moon in the PKT (Figure 5b) is not only associated with late stage LMO crystallization, but also later exhumation following an impact which formed the Imbrium Basin during a period of intense bombardment during the Moon's early history.

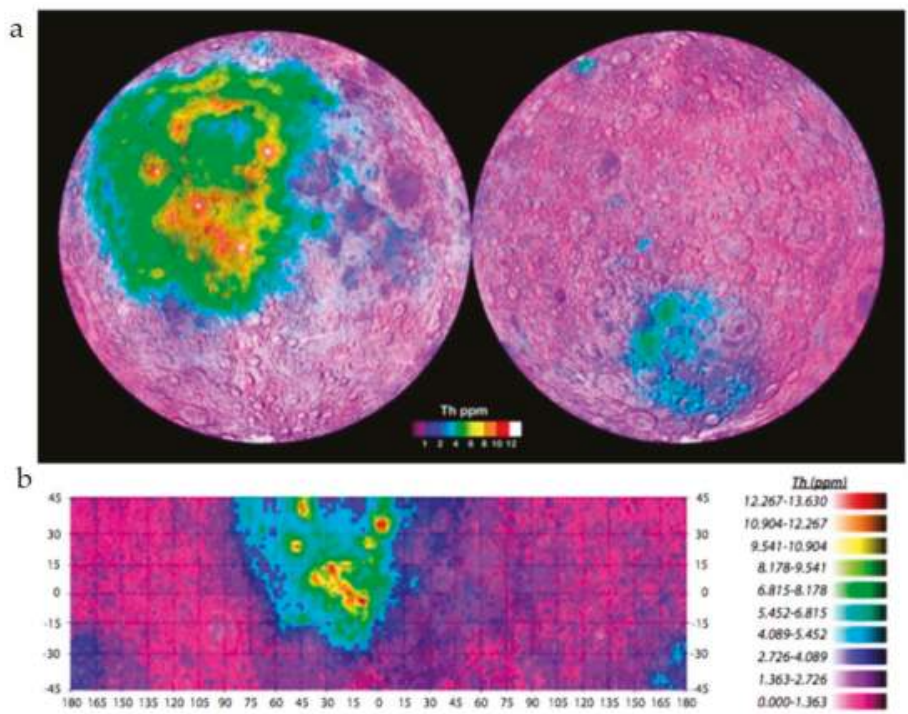

Figure 5. (a) From NASA, Thorium (Th) distribution map of the lunar nearside (left) and far side (right), mapped by the Lunar Prospector. Image available at [108] and used with permission; (b) Gamma ray spectrometer (GRS) generated map of thorium abundances for mid-latitudes with abundances $>12$ ppm in isolated locations. Modified from [105].

The volume of KREEP lithologies underlying Oceanus Procellarum has been estimated at $2.2 \times 10^{8} \mathrm{~km}^{3}$, based on the concentration of radioactive (heat-producing) elements and the area mapped as "high-Th" (Figure 3a, [109-111]). From [109], potential REE reserves in these underlying KREEP rocks has been estimated at $2.25 \times 10^{14}-4.5 \times 10^{14} \mathrm{~kg}$.

\subsection{Lunar REE-Bearing Minerals}

The presence of KREEP components in lunar samples is "unequivocally accepted" yet a pristine urKREEP signature has not yet been found [112]. The composition of urKREEP, from which KREEP-rich lithologies derive their KREEPy signatures, was modelled in [112,113]. Figure 6 summarizes the primitive mantle-normalized REE-signatures of (1) chondrite; (2) different geochemical reservoirs on Earth: upper, middle, lower, and bulk continental crust; (3) the REE-signatures of lunar highland 
samples (FANs), mare basalts, a lunar granite, a lunar dunite, and KREEP-rich lithologies; (4) signatures of REE-bearing phases found on the Moon so far (and discussed in more detail later); and (5) the signature of the urKREEP reservoir. As illustrated in Figure 6, and discussed earlier, the lunar highlands samples and mare basalts display complementary geochemical signatures with positive and negative Eu-anomalies respectively.

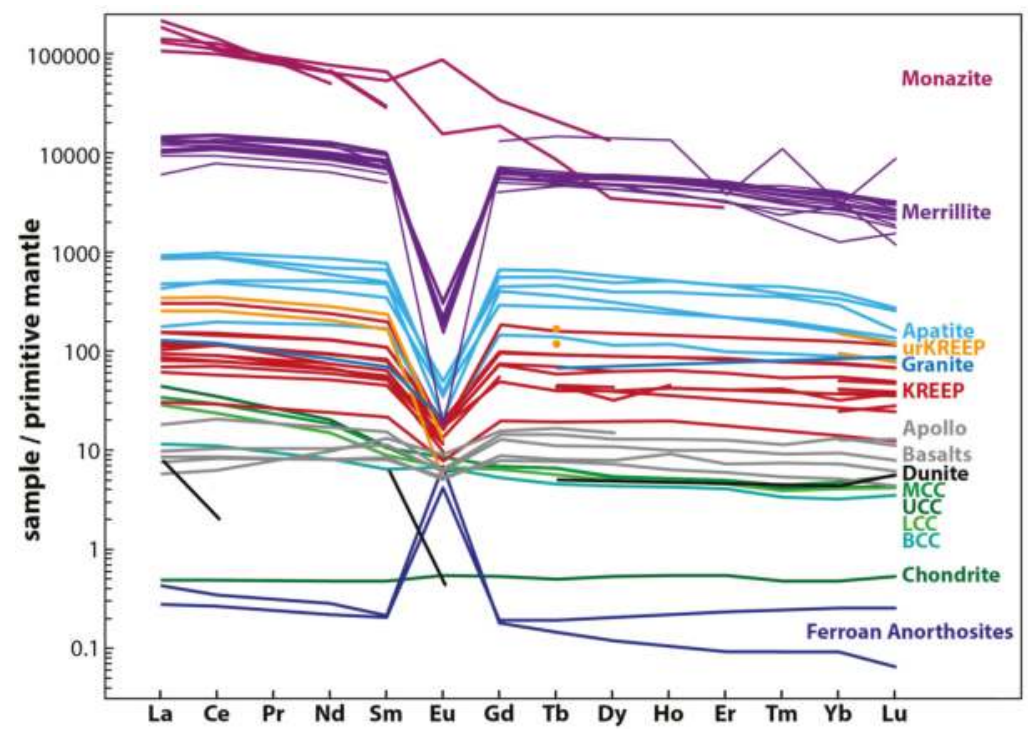

Figure 6. Rare-earth elements-Earth's primitive mantle normalized concentrations of terrestrial and lunar reservoirs, rocks types, and REE-bearing phases. Samples and data sources (all lunar data is available in the Lunar Sample Compendium [94] unless stated otherwise): Ferroan Anorthosites 60025 and 62236; Chondrite: [114]; Dunite: [115]; BCC (Bulk), LCC (Lower), MCC (Middle), and UCC (Upper Continental Crust) from [116]; Apollo Basalts: 12011, 12075, 14053, 15016, and 70017; KREEP basalts 12013, 14073, 14076, 14078, 14303, 14310, 15382, 15386, 15405, 61156, and 72275; Granite: [117]; urKREEP from [112]; Apatite and Merrilite from [118]; and Monazite from [119].

From [112,113] the degree of fractionation that would be required to form a residual liquid during LMO that has the composition of urKREEP is "within the realm" of silicate liquid immiscibility, whereby two melts - one K-rich and one REEP-rich—are segregated. This process has the potential to account for the presence of lunar granites (derived from the K-rich melt) and evolved phosphate phases in highland samples (see discussion later). The KREEP-rich fraction then has the potential to ascend and interact with the lunar crust, potentially acting as a metsomatic agent. As shown in Figure 6, the modeled composition of urKREEP (orange) is elevated in KREEP components relative to the KREEP-like signatures (shown in red), and is higher in KREEP components than any other lunar lithology (Granite, Apollo Basalts, Dunite and the FANs).

The majority of the ITEs on the lunar surface, in rocks and soils, are associated with the PKT (Figure 5). However, the majority of lunar samples contain apatite and/or merrillite as a trace phase (Figure 6), and in samples which exhibit a KREEP signature, merrillite (H-free whitlockite) is almost always present, often co-existing with apatite [120]. Figure 7a-c shows several excellent examples of lunar fluorapatite in an Apollo 10 basalt, and lunar apatite crystals lining vugs in the Apollo 14 breccias. In both examples, (fluroro)apatite occurs as euhedral to subhedral grains. 

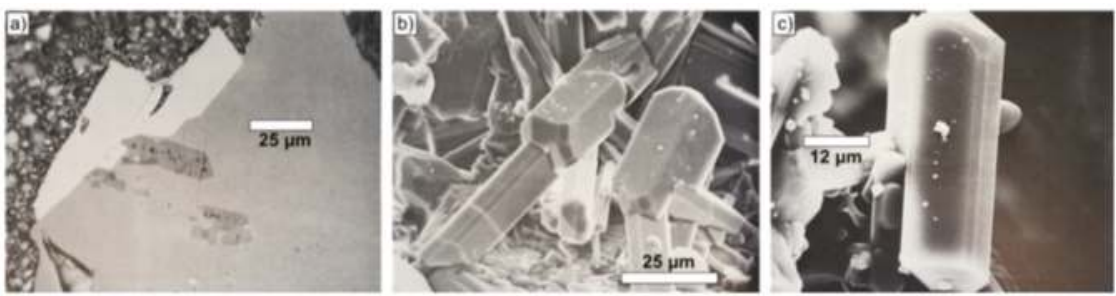

Figure 7. (a) SEM photograph of Apollo 10 basalt (10047): fluorapatite in pyroxferrite, in contact with ilmenite. Upper left portion is epoxy; (b) SEM photograph of apatite crystal in Apollo 14 breccia vug; (c) SEM photograph of doubly terminated apatite crystal in Apollo 14 breccia vug. All images from [95].

Also shown in Figure 6 are normalized REE compositions of REE-bearing phases found throughout the lunar sample collection: apatite, merrillite, and monazite. In lunar merrillite, REE substitutes for $\mathrm{Ca}$, and $\mathrm{H}$ is substituted by $\mathrm{Na}$ and $\mathrm{K}$. This mineral appears to be unique to the PKT with the formula $\mathrm{Ca}_{17.3} \mathrm{Y}_{0.4}(\mathrm{La}-\mathrm{Lu})_{0.88}(\mathrm{Mg}, \mathrm{Mn}, \mathrm{Fe})_{2.4}(\mathrm{Na}, \mathrm{K})_{0.07}(\mathrm{P}, \mathrm{Al}, \mathrm{Si})_{13.9} \mathrm{O}_{56}$ (sample 14310,123; [96]). While significant proportions of the KREEP REE budget are associated with merrillite, which can constitute up to $3 \%$ of a lithologies volume in the PKT, the amount of merrillite is unfortunately too small for economical extraction of metals on the Moon based on current understanding [96]. This of course does not rule out the discovery of future, more concentrated, deposits.

From [121] Apollo 14 Quartz (whitlockite (merrillite) rich) Monzodiorite fragments (2-4 mm) in lunar soil has the highest REE concentrations of any lunar material reported to date (excluding merrillite separates). One 18.4-mg merrillite-rich particle (W-QMD 14161,7373) was found to contain $11 \%$ phosphates and $1 \%$ zircon. This particle exhibited a REE normalized pattern that resembled KREEP, but with a distinctly higher La/Yb ratio (4.78 vs. 3.38 (from 15386)), consistent with the presence of merrillite. The petrogenesis of this highly enriched REE sample was reconciled in a silicate-liquid immiscibility model after fractional crystallization involving merrilite. This model was also used to account for some of the observed geochemical trends in lunar granites [112,113,121]. KREEPy geochemical signatures are also present in impact melt breccias (IMBs) collected from the Apollo landing sites (most notably 14, 15, 16, and 17; [122]). These samples have an average (from each landing site) $\mathrm{La}(\mathrm{ppm})$ ranging from 21.2 to 87.4 , Ce (ppm) from 55 to 224, Sm (ppm) from 9.92 to 38.5, and $\mathrm{Lu}$ (ppm) from 0.92 to 3.82 [122] but exhibit similar inter-element ratios: $\mathrm{La} / \mathrm{Lu}$ : 22.8-23.0; Ce/Sm: 5.5-5.8; Ce/Lu: 58.6-59.8 which attest to their LREE enrichment.

One other REE-bearing lunar phase, which is present in lower abundance relative to merrillite and apatite, is monazite. Until 2006 monazite had only been identified as small $(10 \mu \mathrm{m} \times 3 \mu \mathrm{m})$ inclusions in pyroxene from Apollo 11 basalts (sample 10047,68; Figure 6; [95]). Additional lunar monazites were reported in [119], where particles $\sim 0.5-3 \mu \mathrm{m}$ in size were identified in regolith from the Luna 24 samples. One striking feature of one of these newly identified monazites was the positive Eu-anomaly (Figure 6) and associated lack (below detection limit) of Th. This was attributed to crystallization from an aqueous solution during metasomatic alteration of Eu-rich plagioclase in primary mare basalts which contained REE-bearing phases (merrillite and apatite for example; [119]).

In addition to monazite, merrillite, and apatite, the REE-rich phase yittrobetafite has been found in sample 14321,1494 (a clast-rich, crystalline matrix breccia known as "Big Bertha") and contains 17.67 wt. $\% \mathrm{Nb}_{2} \mathrm{O}_{3} ; 4.33$ wt. \% $\mathrm{UO}_{2}$ (38,200 ppm U); 2.38 wt. \% $\mathrm{Nd}_{2} \mathrm{O}_{3}(20,420$ ppm Nd); 12.00 wt. \% $\mathrm{Y}_{2} \mathrm{O}_{3}(94,500$ ppm Y); and 12.81 wt. \% REEs [123].

At the time of its identification in Apollo 11 and Apollo 12 basalts, the mineral tranquillityite was not only a new lunar silicate mineral, it was a new mineral. Initially, it was identified as " $A$ " and as an "unnamed yttrium-zirconium silicate" in $[124,125]$ respectively. It is associated with interstitial phases (e.g., troilite), and occurs as thin laths in coarse-grained cristobalite [126]. Geochemically, it is enriched 
in $\mathrm{Zr}$ (12-13 wt. \%), Y (1.0-4.6 wt. \%), and Nd (0.1-0.25 wt. \%), and was not discovered on Earth until 2011 (in Australia, [127]).

In order for a mineral deposit to be mined as an ore, the concentration of the desired element must be high enough for economic extraction, meaning that its initial abundance must also be high enough so that a differentiation process can concentrate it. While samples from the Apollo 14 and 15 collections exhibit REE concentrations higher than urKREEP (up to four times higher), their abundances are still low relative to terrestrial ores $[24,42,128]$. However, direct sampling of the high Th regions of the PKT (Figure 5), has not yet occurred and with the spatial resolution at $10 \mathrm{~s}$ of $\mathrm{km}$, the PKT has the potential to have higher REE concentrations at a local scale, hence future explorations may yet yield REE deposits that are viable for exploitation and extraction [24].

\subsection{Other Potential Lunar Resources}

The natural resources on the Moon can be classified into the following categories: rocks and minerals, soil (regolith), and fumaroles and vapor deposits [129]. All of these have the potential to be processed and utilized as metals, ceramics, and glass. Despite all the elements that are present on Earth being present on the Moon, several of Earth's widely used elements (such as copper, gold, and chlorine) are widely dispersed and, based on current understanding, not concentrated in viable deposits on the Moon [26]. Lunar resources have several broad uses, none of which are mutually exclusive (1) lunar exploration support (In-Situ Resource Utilization, or ISRU); (2) support of economic and inquiry-driven science in the near-Earth-Moon region of the Solar System; (3) contributions to Earth's global economy; and (4) provision of resources (including through recycling) in support of Mars missions [24,30,130-133].

Lunar resources that have gained significance, many of which have been previously presented and discussed in $[24,26,133,134]$, are briefly summarized here.

\subsubsection{Helium-3}

Helium-3 has the potential to be used as a fuel for atomic fusion reactors [133]. In the absence of a magnetic field and an atmosphere, the lunar regolith has been successively implanted with solar wind particles (ions) for billions of years from which trapped $\mathrm{H}$ and $\mathrm{He}$ could be released. In this case, $\mathrm{H}$ could be used for rocket fuel, and ${ }^{3} \mathrm{He}$ as an energy source $[24,26,135,136]$.

\subsubsection{Water}

Evidence (indirectly) for water at the lunar poles was provided by the Lunar Prospector, and later supported by the Lunar Crater Observation and Sensing Satellite mission which reported a concentration of $5.6 \pm 2.9 \mathrm{wt}$. \% $(1 \sigma)$ for water ice in lunar regolith [137-139]. Considering a water mass of $5.6 \mathrm{wt}$. \%, and a density for the lunar regolith of $1660 \mathrm{~kg} / \mathrm{m}^{3}$, a potential 2900 million tonnes of water exists within the upper $1 \mathrm{~m}$ of regolith [24]. Based on current human consumption of 10 billion tonnes of freshwater per day (www.theworldcounts.com/stories/average-daily-waterusage), and 80-100 gallons of water use/person/day [140], 2900 million tonnes (of lunar freshwater) would sustain today's global population for $1 \mathrm{~min}$ and $12 \mathrm{~s}$, and one individual for 20.1-26.2 billion years (based on current average use).

\subsubsection{Oxygen}

Oxygen could be sourced from lunar water, either from polar ice or hydrated regolith from pyroclastic deposits [24]. In addition to this, 20 different approaches exist for extracting oxygen from the lunar regolith (8 of which can be considered plausible, [141]). Oxygen could also be exploited from the more extensive lunar highlands, where anorthite is abundant ([142] Schwandt pers. comm. in [24]). 


\subsubsection{Aluminum}

Aluminum (Al) is widely used throughout society today in fuselages of aircraft, food and beverage packing containers, packaging, kitchen utensils and beer kegs, to name but a few. It is the most abundant metal in Earth's crust $(\sim 8 \%)$ where it is mined from bauxite and cryolite ores. The lunar highlands are however comparatively enriched with between 10 and $18 \mathrm{wt} \% \mathrm{Al}$ due to the abundance of anorthitic plagioclase feldspar, from which Al could be extracted [24,26,141].

\subsubsection{Magnesium}

Magnesium (Mg) is widely used in the manufacturing of race cars, airplanes, and bicycles (Grey, 2012). On the Moon, Mg is an abundant component of the lunar regolith, and certain lunar lithologies, predominantly in the form of $\mathrm{MgO}$ in olivine. Within the context of lunar exploration, it has the potential to be utilized in situ (ISRU) to form alloys and contribute to the manufacturing of a lunar base [143,144].

\subsubsection{Iron}

Historically, Iron ( $\mathrm{Fe}$ ) was a dominant component of the Industrial Revolution and since then has been widely utilized in the production of alloys (e.g., steel) due to the ease at which it can be tempered. Similar to to $\mathrm{Mg}$, it is an essential component of the lunar regolith in the form of ilmenite $(\sim 10 \%)$ and as Fe particles [145] while the lunar crust contains $\sim 3 \mathrm{wt} \% \mathrm{Fe}$ [146]. Utilization of all metals (including $\mathrm{Al}$ and $\mathrm{Mg}$ ) as an in-situ resource on the Moon is a "logical step" in the exploration of space [145].

\subsubsection{Basaltic Glass}

Basaltic glass, and in particular glass fibers, could be used as structural reinforcements in lunar concrete structures supporting the development other ISRU technologies [147-150].

\subsubsection{Vacuum}

From [133], telescopes placed on the lunar surface would experience a "lack of an attenuating atmosphere" while any metallic component would not rust. In addition, the lack of an atmosphere would also limit the distortion and attenuation of laser beam communication, and promote technological advancement, particularly in the production of glass from the regolith.

\subsubsection{Lunar Regolith}

The composition of the lunar regolith represents the results of billions of years of impacts $[28,127,150-152]$. This has been of specific interest due to its potential application as a construction or manufacturing material, as a chemical consumable, or as a propellant $[24,153,154]$ and will likely provide the initial (and major) lunar resource [29]. More recently, lunar regolith has been proposed as a material that could be utilized in 3-D printing technology to build lunar infrastructure (e.g., [154]).

\subsection{REEs beyond the Moon}

The only other planet from which samples are known to have been derived from is Mars. Yet compared to Earth and the Moon, relatively little is known about the differentiation and geological evolution of the red planet (e.g., [155]). To date, there have been no sample return missions hence our understanding of Martian geology is based on the 107 meteorites (as of 1 August 2017, [156], and their associated pairs) that have survived passage through Earth's atmosphere. This number is considerably less than the 344 lunar meteorites identified so far, and their pairings (as of 1 August 2017, [157]) and the $>1000$ samples brought back by the Apollo missions (including rock samples and lunar regolith, [158]). 
From the REE characteristics of martian meteorites, it has been shown that Mars differentiated very early in the history of the Solar System $(\sim 4.5 \mathrm{Ga})$ to form a metallic core, a silicate mantle, and a crust, and broadly differentiated to form a LREE-depleted reservoir (low La/Yb, high Sm/Nd) and an inferred, complementary LREE-enriched reservoir (high La/Yb, low Sm/Nd; [159]), the latter of which remains to be directly sampled (see discussion later; e.g., [160-167]). Unlike the lunar sample collection and the lunar magma ocean model (Figures 3 and 4), Mars lacks an Al-rich anorthositic crust. This observation is attributed to crystallization of garnet during Mars magma ocean crystallization (e.g., $[159,165])$. As Mars is larger than the Moon ( twice the diameter), higher pressure in the planet's interior would have promoted the crystallization of high pressure phases, such as garnet. This would have had a significant impact on the crystallization sequence of a magma ocean as garnet contains Aluminum. From experiments at pressures of 3-5 GPa, the following sequence for martian magma ocean crystallization has been proposed: olivine $\rightarrow$ olivine + orthopyroxene $\rightarrow$ orthopyroxene + clinopyroxene $\rightarrow$ clinopyroxene + garnet + ilmenite $\rightarrow$ clinopyroxene + garnet [168] . At higher pressures, the crystallization of garnet occurs earlier, but between the crystallization models is the consistent absence of plagioclase (see [168]). Following $~ 99.5 \%$ martian magma ocean crystallization, a late-stage liquid enriched in incompatible elements (including KREEP) has been modelled. The overall geochemical characteristics of this evolved reservoir are very similar to lunar KREEP [168].

As presented earlier within the context of the Moon, REE-bearing minerals are volumetrically rare in extraterrestrial samples. This can be in part attributed to the scarcity of felsic igneous rocks (as sampled to date) and the lack of high-temperature fluids which would concentrate these elements. With no sample return missions having yet been completed to Mars, mineralogical and chemical information is derived from (1) elemental surface maps obtained by Mars-orbiting satellites (e.g., the Gamma-Ray Spectrometer (GRS) on board Mars Odyssey); (2) landers and rovers on the martian surface (e.g., the Mariner missions, Mars 3, Viking 1, Viking 2, Pathfinder, Opportunity, Phoenix, and most recently Curiosity); and (3) meteorites.

Maps from the GRS instrument have summarized the distribution of chlorine, calcium, potassium, iron, silicon, and hydrogen across the martian surface, where like the Moon (Figure 5), thorium exhibits a high degree of correlation with potassium $[169,170]$. From these results, the martian surface has been shown to be broadly composed of basaltic material (iron, silicon, calcium), sulfur, chlorine, hydrogen, potassium, and thorium in addition to elements that were not mapped by the GRS (e.g., magnesium and sodium; [170]). More recent results from analyses of martian soil in Gale Crater by Curiosity's onboard instruments (ChemCam and APXS (Alpha Particle X-ray Spectrometer)) reveal a dominance of silicon, titanium, aluminum, iron, magnesium, calcium, and sodium. Other elements detected included potassium, chromium, manganese, phosphorus, sulfur and chlorine [171].

To date, only one of the meteorites-a polymict regolith breccia (sample NWA 7034) and its paired stones-is considered representative of the modern-day martian surface, with the other 106 Martian samples being igneous in nature (shergottites, orthopyroxenite, clinopyroxenite, dunite) and thus providing insights into the evolution of the Martian interior [156,172-175]. Figure 8a illustrates and summarizes the REE characteristics of these different classes of martian meteorites (including NWA 7034), along with the patterns of individual REE-bearing phases within NWA 7034 recently sampled by [176]. As shown, NWA 7034 exhibits LREE enrichment in comparison to other martian rock types with absolute concentrations of $\mathrm{La}$ and $\mathrm{Lu}$ of 13.7 and $4.3 \mathrm{ppm}$, respectively. Throughout the igneous lithologies, the enriched basaltic shergottite exhibits the highest concentrations of REEs with $4.4 \mathrm{ppm} \mathrm{La}, 8.4 \mathrm{ppm} \mathrm{Nd}, 4.7 \mathrm{ppm} \mathrm{Gd}$, and $0.43 \mathrm{ppm} \mathrm{Lu}$ (sample NWA 7257) while the orthopyroxenite and the depleted olivine-phyric shergottite exhibit the lowest LREE abundances (La at 0.15 and $0.29 \mathrm{ppm}$ respectively, $\mathrm{Ce}$ at 0.43 and $1.07 \mathrm{ppm}$ respectively). The orthopyroxenite and dunite samples exhibit the lowest HREE abundances $(0.255$ and $0.11 \mathrm{ppm} \mathrm{Yb}$ respectively, and 0.037 and $0.015 \mathrm{ppm}$ Lu respectively). 

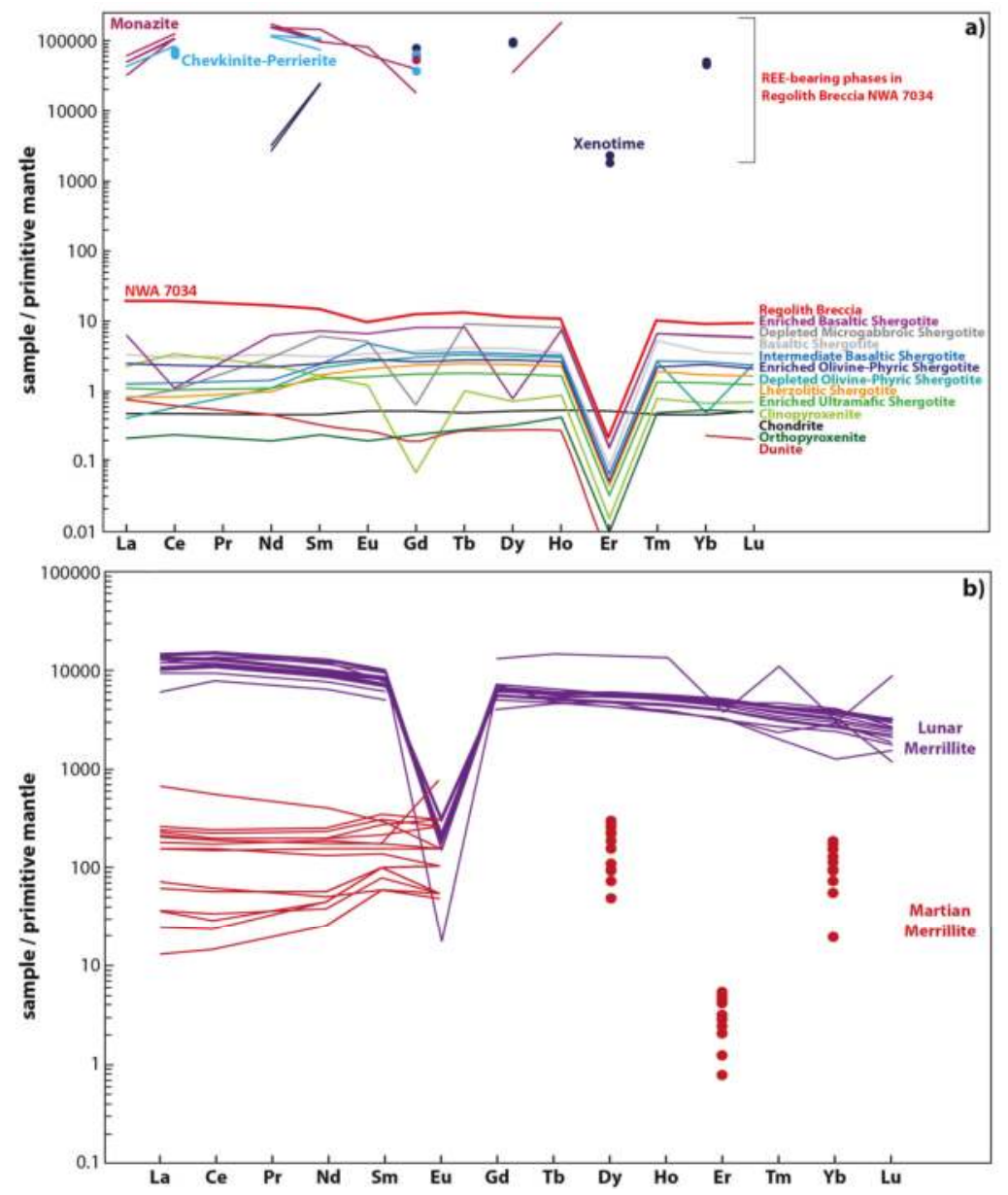

Figure 8. (a) Summary of the REE characteristics of martian samples including the recently discovered regolith breccia, NWA 7034 and its REE-bearing phases. All data is available through the Martian Meteorite Compendium [177]. NWA 7034 data from [176]; (b) Comparison of lunar and martian merrillite. Data sources: [116,178].

The most common REE-bearing phase throughout the martian meteorite collection is merrillite $\left(\left(\mathrm{Ca}_{3}\right)\left(\mathrm{PO}_{4}\right)_{2}\right)$, a common accessory phases in extraterrestrial samples (as is apatite, see earlier discussion of the Moon). Throughout the martian sample collection, merrillite has been identified as the dominant host of the REEs [178]. Merrillite has been found in the shergottites (olivine-phyric, basaltic, lherzolitic), the orthopyroxenite, and the recently discovered regolith breccia (Figure 8a). As shown in Figure 8b, the abundances of the REEs in martian merrillites are significantly lower than in lunar merrillites. Broadly, the REEs substitute into the Ca site in the merrillite crystal structure, a substitution that is demonstrably more pronounced in lunar merrillites (Figure 8b). This observed difference is almost two orders of magnitude with respect to the LREEs (Figure 8b) and has been attributed to differences in their source melt composition, with the relatively depleted LREE patterns associated with derivation from depleted martian mantle sources [178], and the relatively enriched LREE patterns $\left(\mathrm{La}_{\mathrm{N}}\right.$ up to 699 , where " $\mathrm{N}$ " refers to the primitive-mantle normalized value) associated with LREE enrichment (e.g., [179]). This enrichment has been hypothesized to be associated with post martian 
mantle differentiation, potentially as a result of small degrees of partial melting which concentrated a LREE component which was assimilated by a parental magma (e.g., [180,181]). Alternatively, this LREE component has been suggested to have been derived from the Martian crust (e.g., [182]) or a KREEP-like component associated with late-stage martian magma ocean crystallization and similar to that which has been identified in lunar samples (see earlier, e.g., Borg and $[63,183]$ ). While the origin of this LREE-enriched component remains poorly constrained (e.g., [184]), the differences between lunar and martian merrillites indicate that Mars experienced a different petrogenetic history than the Moon (Figure 8b; e.g., [120]).

Sample NWA 7034 (and two of its paired stones) have been reported by $[176,185,186]$ as the first Martian rocks to contain apatite $\left(\left(\mathrm{Ca}_{5}\left(\mathrm{PO}_{4}\right)(\mathrm{F}, \mathrm{Cl})\right)\right.$;-hosted monazite $\left((\mathrm{LREE}) \mathrm{PO}_{4}\right)$, monazite ((LREE) $\left.\mathrm{PO}_{4}\right)$-chevkinite-perrierite $\left((\mathrm{Ce}, \mathrm{La}, \mathrm{Ca}, \mathrm{Th})_{4}\left(\mathrm{Fe}^{2+}, \mathrm{Mg}\right)_{2}\left(\mathrm{Ti}^{2} \mathrm{Fe}^{3+}\right)_{3} \mathrm{Si}_{4} \mathrm{O}_{22}\right)$ in a clast, and coexisting chevkinite-perrierite respectively (Figure 8a). In the most recent study [176], xenotime and merrillite are also reported (Figure 8a). The major mineralogy of these martian surface rocks is characterized by alkali feldspar, plagioclase, pyroxene, with minor magnetite, pyrite, zircon, and phosphates [173-175] with the newly identified REE-bearing phases listed above all present at the sub-micrometer scale. From [176], monazite was found as inclusions in apatite and was proposed as having an origin associated with fluid-phosphate and fluid-rock interactions occurring at elevated temperatures on Mars, within the source rocks prior to their incorporation into the regolith breccia. These hydrothermal fluids were hypothesized to have originated from igneous intrusions intruding into the martian crust, or from impacts. This latter hypothesis presents a scenario in which REE-mineralization on Mars could be linked to impact cratering and thus presents craters as a potential location for REE- mineral resources on Mars [176].

Beyond samples from the Moon and Mars, other REE-bearing phases within other types of extraterrestrial materials are known. A summary of the REE characteristics of the most common type (broadly classified as stones, or stony-type) is shown in Figure 9. 


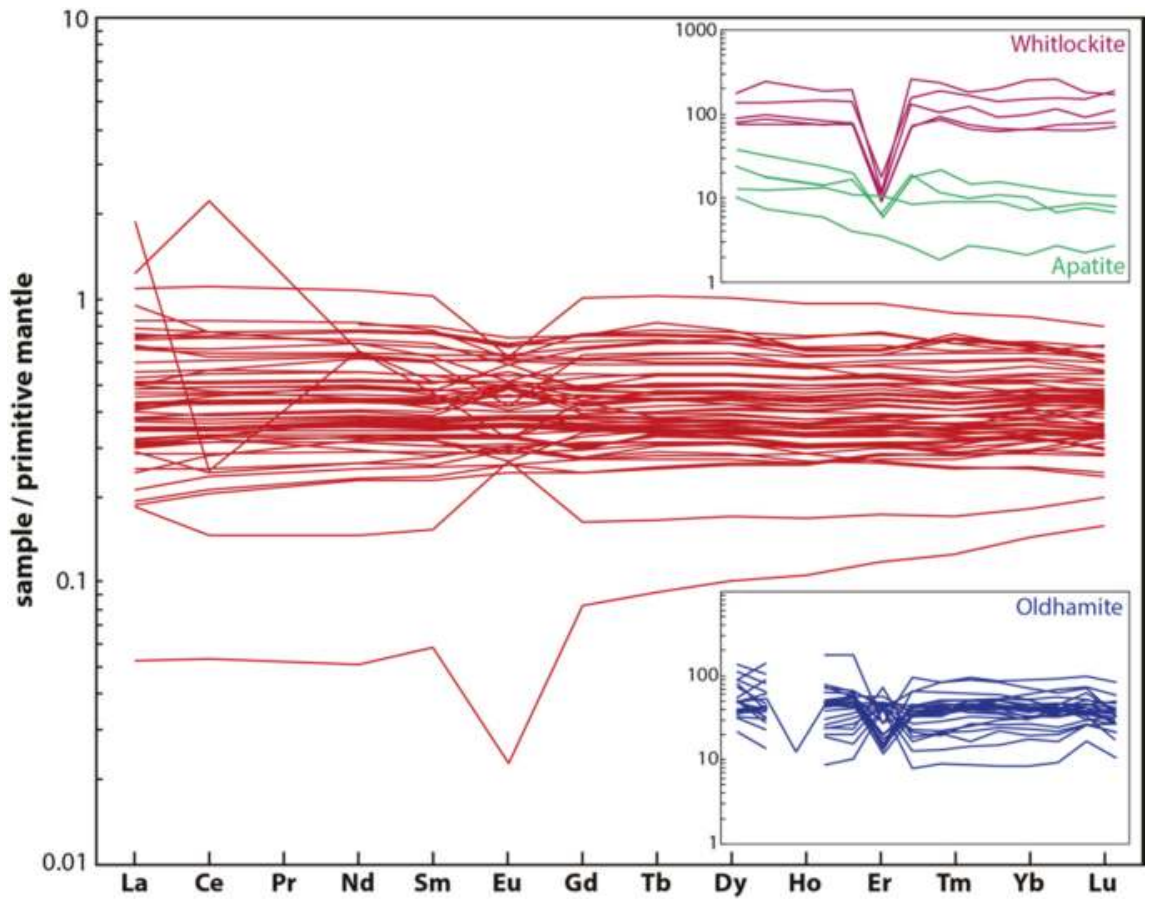

Figure 9. Summary of the REE characteristics of stony meteorites (chondrites types CI1, CM2, CO3, CV3, EH3, EH4, EH5, EL6, EH6/7, EL7, H4, H6, L4, L5, L6, LL4, LL5, and LL6, achondrite type: aubrite). Data source: [187]). Also shown are two inset graphs which illustrate the REE characteristics of several of the REE-bearing phases found within the stony meteorites. Results from oldhamite are shown in blue (data from from achondrite aubrite samples Bustee and Mayo Belwa, and two EL6 chondrite: Jajh deh Kot Lelu and Khairpur; [188]). Results from apatite and whitlockite are shown in green and purple, respectively (data from $\mathrm{H} 4$ chondrite Yamato-74371; [189]).

Of the 63 bulk rock primitive-mantle normalized REE signatures shown in Figure 9, 61 are chondrites (including samples from the following categories: CI1, CM2, CO3, CV3, EH3, EH4, EH5, EL6, EH6/7, EL7, H4, H6, L4, L5, L6, LL4, LL5, and LL6) and two are achondrites (classification: aubrite). The two aubrite samples represent the two most REE-depleted samples, consistent with their differentiated nature. As has been discussed within the context of lunar and martian samples, REEs are typically concentrated in minor phases. This is also the case with respect to the stony meteorites with sub-mm phosphates (e.g., apatite, whitlockite, and merrillite) and oldhamites ((Ca, $\mathrm{Mg}, \mathrm{Fe}) \mathrm{S}$ ) being common carriers of the REEs (up to $\sim 1600 \mathrm{ppm}$, or $0.16 \mathrm{wt}$. \%). These phosphate phases are estimated to constitute $\sim 0.6 \%$ of the whole rock sample [190] and their REE patterns are shown as insets in Figure 9. Broadly, these REE-bearing phases are enriched by 1-2 orders of magnitude in comparison to the bulk samples but do not extend to the same degree of enrichment as observed in lunar and martian minor phases (Figures 6 and 8).

As shown by the bulk stony meteorite data in Figure 9, little difference exists between the different types of chondrites. They exhibit low REE abundances and are therefore unlikely to represent a viable extraterrestrial REE resource. This is consistent with the findings of [191] who discussed the possibility of mining chondritic asteroid materials. While the REEs of these types of extraterrestrial materials are "not worth mining yet" and that the mining "makes little sense", due to their low abundances, [191] proposed they could be a potential platinum group element (PGE) resource. The PGEs include the 
elements platinum $(\mathrm{Pt})$, palladium $(\mathrm{Pd})$, iridium $(\mathrm{Ir})$ osmium $(\mathrm{Os})$, rhodium $(\mathrm{Rh})$, and ruthenium $(\mathrm{Ru})$. These elements are of industrial significance with applications to the (petro)chemical and technological sectors. For example, $\mathrm{Pt}$ is widely used in the production of catalytic convertors and is combined with rhodium to produce an alloy utilized in fertilizers and explosives [192].

\subsection{Missions beyond the Moon}

Current plans to explore Mars include NASAs upcoming InSight (Interior Exploration using Seismic Investigations, Geodesy and Heat Transport) mission and the Mars 2020 rover. The InSight mission will place a lander on the Martian surface with a launch date of 5 May 2018, and a landing date of 26 November 2018 [193]. The objective of this mission is to explore the Martian interior. The Mars 2020 rover is scheduled to launch in July/August 2020 with a proposed landing in February 2021 [194]. One of the aims of this mission to prepare for human exploration of Mars which will in-part be achieved through extraction of oxygen from $\mathrm{Mars}^{\prime} \mathrm{CO}_{2}$ rich $(\sim 96 \%)$ atmosphere. Current plans for human exploration of Mars through NASA missions are associated with sending humans to the red planet in the 2030s [195]. Associated with this goal is transport of equipment to cislunar space and the establishment of a "deep-space gateway". Phase 1 of this is scheduled between 2018 and 2026 and would include four crewed flights that would deliver key components of the Deep Space Transport vehicle to cislunar space ([195], see also [196]). At the time of writing, no known mission plans exist to mine Mars with the existence of ores on Mars (REE-dominated or not) "hypothetical" [197]. Alongside NASAs interest in the red planet, the European Space Agency (ESA), in collaboration with the Roscosmos State Corporation, is planning to send its ExoMars lander in 2020. In addition, several nongovernmental organizations also have plans to explore Mars with SpaceX planning to launch robotic capsules in 2018 and Mars One planning robotic missions in 2020, 2022, and 2024 [198].

In addition to current, upcoming, and proposed missions to the Moon and Mars (see earlier), in situ chemical characterization of other rocky objects in our Solar System through missions to Near Earth Asteroids (NEAs) aim to advance our understanding of the elemental composition of planetary materials. This approach to quantifying the geological and geochemical features of nearby objects was pioneered in 2001 through NASAs Near-Earth Asteroid (NEA) Rendezvous-Shoemaker mission to Eros, the second largest NEA [199]. More recently, the Hayabusa mission administered by the Japanese Space Program, JAXA (Japan Aeropsace Exploration Agency), landed on NEA 25143 Itokawa in 2005. This led to the return of regolith samples to Earth in 2010 [200]. A follow-up mission, Hayabusa 2, launched in 2014 to asteroid 162173 Ryugu. This mission is scheduled to land on the asteroids surface in 2018 prior to returning samples to Earth in 2020 [201]. More recently, 2016 saw the successful launch of OSIRIS-Rex (Origins-Spectral Interpretation-Resource Identification-Security Regolith Explorer) to the asteroid 101955 Bennu. This mission represents NASAs first attempt to return samples to Earth from a NEA [202].

Whether an extraterrestrial resource is identified as an (REE) ore deposit or water, or even something else, the resources first need to be evaluated, the technology associated with their mining and extraction demonstrated and validated, and successful extraction and application shown [28]. As presented here, there are extraterrestrial sources of REEs in the form of volumetrically minor phosphate phases in lunar, martian, and other meteoritic material. Despite there being little geological and geochemical evidence to support the notion that these REEs exist in concentrations where mining them would be justifiable $[186,188]$ future explorations may change this [24]. It is likely that the future exploration of space will also be pursued for commercial reasons (Virgin Galactic as a current example) yet science stands to be a significant beneficiary of this endeavor [203].

\section{Conclusions}

Daily use of REEs by modern day society is placing an increasing demand for extraction of these elements from limited terrestrial resources. With an increasing population, a projected 8.5 billion by 2020, it is natural to consider exploration and characterization of extraterrestrial REE sources in 
order to sustain our reliance on raw materials and energy reserves. Earth's nearest neighbor in space, the Moon, is a logical first target both in terms of evaluating resource potential.

Following formation of the Moon as the result of a giant impact between proto-Earth and an impacting Mars-sized body c. 70-100 Myrs after the onset of Solar System formation, molten material (a primordial magma ocean) began to solidify and differentiate. After $\sim 99 \%$ crystallization a KREEP (potassium, rare-earth element, phosphorus)-rich layer concentrated incompatible elements, a geochemical signature detected in many lunar samples today. Today, KREEP-rich lithologies are associated with enrichments in thorium on the lunar near-side (in the PKT), as observed by the gamma ray spectrometer on the Lunar Prospector. The volume of KREEP-rich lithologies associated with this region of the Moon is estimated at $2.2 \times 10^{8} \mathrm{~km}^{3}$, with potential reserves of REEs at $2.25 \times$ $10^{14}-4.5 \times 10^{14} \mathrm{~kg}$. The majority of lunar samples contain REE-bearing phases as minor or trace components, typically apatite and/or merrillite with KREEP-like lithologies almost always containing merrillite. The presence of merrillite has the potential to account for up to $3 \%$ of a lithologies volume in the PKT however, this does not permit the classification of REEs on the Moon as ores. While REE abundances of trace phases in lunar rocks are high, their abundances are low compared to terrestrial ores meaning there is to date, no geological evidence to support mining the Moon for REEs yet. With the development of future technologies capable of mapping at higher resolutions, and in situ exploration by future missions, economically viable lunar resources may yet be discovered. However, other potential resources do currently exist on the Moon-including helium-3, water, oxygen, and metals ( $\mathrm{Fe}, \mathrm{Al}, \mathrm{Mg})$ - which will likely be fundamental to future space exploration.

Beyond the Moon, samples from Mars and chondritic meteorites are also host to REEs, predominantly hosted in merrillite, in addition to apatite, whitlockite, xenotime, and recently-identified chevkinite-perrierite. These minor phases dominate the REE budget with abundances 1-2 orders of magnitude higher than their bulk host rock. However, as with the Moon, REEs have not yet been found in high enough concentrations in these extraterrestrial samples to warrant their classification as an ore resource. The concentrations of REEs in martian merrilites for example are several orders of magnitude lower than lunar merrillites, a difference attributed to the planetary bodies' crystallization history during the early evolution of the Solar System.

While the relative concentrations and abundances of the REEs in the phases that have been characterized to date provide crucial insights into the differentiation history of planetary objects, current and future missions to the Moon, Mars, and other nearby objects in our Solar System may yet reveal one or more extraterrestrial REE resources that one day will be utilized.

Acknowledgments: We thank Guest Editor Simon Jowitt for the opportunity to contribute to this special issue on the criticality of rare-earth elements. We are also very grateful to two anonymous reviewers who provided comments and thoroughly constructive feedback on an earlier draft of this manuscript. Our contribution was greatly improved by their input and suggestions.

Author Contributions: Claire L. McLeod designed the structure, collected the materials to be included in the review of REEs in planetary materials, and wrote $90 \%$ of this article. Mark P. S. Krekeler wrote the "The Criticality of REEs in Our Society" section discussing the current uses and demands for REEs, and claims a $10 \%$ authorship contribution.

Conflicts of Interest: The authors declare no conflict of interest.

\section{References}

1. Reinstein, E.R. Owning Outer Space. Northwest. J. Int. Law Bus. 1999, $20,1$.

2. Chakhmouradiani, A.R.; Wall, F. Rare Earth Elements: Minerals, Mines, Magnets (and More). Elements 2012, 8, 333-340. [CrossRef]

3. USGS. Rare Earths Statistics and Information. 2017. Available online: https://minerals.usgs.gov/minerals/ pubs/commodity/rare_earths/ (accessed on 18 March 2017).

4. Haque, N.; Hughes, A.; Lim, S.; Vernon, C. Rare Earth Elements: Overview of Mining, Mineralogy, Uses, Sustainability and Environmental Impact. Resources 2014, 3, 614-635. [CrossRef] 
5. Haskin, L.A.; Frey, F.A.; Schmitt, R.A.; Smith, R.H. Meteoritic, Solar and Terrestrial Rare-Earth Distributions. Phys. Chem. Earth 1966, 7, 167-321. [CrossRef]

6. Kynicky, J.; Smith, M.P.; Xu, C. Diversity of Rare Earth Deposits: The Key Example of China. Elements 2012, 8,361-367. [CrossRef]

7. USGS. Mineral Commodities Survey, U.S. Department of the Interior. 2014. Available online: https://minerals.usgs.gov/minerals/pubs/mcs/2014/mcs2014.pdf (accessed on 31 March 2017).

8. Gray, T. The Elements, a Visual Exploration of Every Known Atom in the Universe; Black Dog and Leventhal Publishers: New York, NY, USA, 2012; 240p.

9. DOE. U.S. Department of Energy Critical Materials Strategy. 2011. Available online: https:/ /energy.gov/ sites/prod/files/DOE_CMS2011_FINAL_Full.pdf (accessed on 6 August 2017).

10. Golev, A.; Scott, M.; Erskine, P.D.; Ali, S.H.; Ballantyne, G.R. Rare earth supply chains: Current status, constraints and opportunities. Resour. Policy 2014, 41, 52-59. [CrossRef]

11. Goonan, T.G. Rare Earth Elements—End Use and Recyclability; Scientific Investigations Report 2011-5094; United States Geologic Survey. Available online: https:/ / pubs.usgs.gov/sir/2011/5094/pdf/sir2011-5094. pdf (accessed on 6 August 2017).

12. Lewis, L.H.; Jimenez-Villacorta, F. Perspectives on permanent magnet materials for energy conversion and power generation. Metall. Mater. Trans. A 2013, 44A, 2-20. [CrossRef]

13. Graso, V.B. Rare Earth Elements in National Defense: Background, Oversight Issues and Options for Congress; Congressional Research Service Report 7-5700, R41744; Congressional Research Service, 2013; Available online: https://fas.org/sgp/crs/natsec/R41744.pdf (accessed on 21 May 2017).

14. Carrettin, S.; Concepcion, P.; Corma, A.; Nieto, J.M.L.; Puntes, V.F. Nanocrystalline $\mathrm{CeO}_{2}$ increases the activity of $\mathrm{Au}$ for $\mathrm{CO}$ oxidation by two orders of magnitude. Angew. Chem. Int. Ed. 2004, 43, 2538-2540. [CrossRef] [PubMed]

15. Trovarelli, A.; de Leitenburg, C.; Boaro, M.; Dolcetti, G. The utilization of ceria in industrial catalysis. Catal. Today 1999, 50, 353-367. [CrossRef]

16. Gester, S.; Metz, P.; Zierau, O.; Vollmet, G. An efficient synthesis of the potent phytoestrogens 8-prenylnaringenin and 6-(1,1-dimethlyallyl)naringenin by europium(III)-catlyzed Claisen rearrangement. Tetrahedron 2001, 57, 1015-1018. [CrossRef]

17. Amin, S.; Voss, D.A.; Horrocks, W.D.; Lake, C.H.; Churchill, M.R.; Morrow, J.R. Laser-induced luminescence studies and crystal structure of the Europium(III) complex of 1,4,7,10tetrakis(carbamoylmethyl)-1,4,7,10-tetraazacyclododecane-The link between phosphate diester binding and catalysis by lanthanide(III) macrocyclic complexes. Inorg. Chem. 1995, 34, 3294-3300. [CrossRef]

18. Gai, S.; Li, C.; Yang, P.; Lin, J. Recent progress in rare earth micro/nanocrystals: Soft chemical synthesis, luminescent properties, and biomedical applications. Chem. Rev. 2014, 114, 2343-2389. [CrossRef] [PubMed]

19. Gambogi, J. Rare Earths in Mineral Commodity summaries USGS. 2016. Available online: https://minerals. usgs.gov/minerals/pubs/commodity/rare_earths/mcs-2016-raree.pdf (accessed on 12 May 2017).

20. United Nations. UNFPA Revision of Population Prospects; United Nations, 2015; Available online: https://esa.un.org/unpd/wpp/publications/files/key_findings_wpp_2015.pdf (accessed on 8 May 2017).

21. Ali, S.H.; Giurco, D.; Arndt, N.; Nickless, E.; Borwn, G.; Demetriades, A.; Durrheim, R.; Enriquez, M.A.; Kinnaird, J.; Littleboy, A.; et al. Mineral supply for sustainable development requires resource governance. Nature 2017, 543, 367-372. [CrossRef] [PubMed]

22. Badescu, V. Moon: Prospective Energy and Material Resources; Springer: New York, NY, USA, 2012; 771p.

23. Crawford, I.A.; Joy, K.H. Lunar exploration: opening a window into the history and evolution of the inner Solar System. Philos. Trans. R. Soc. A 2014, 372, 20130315. [CrossRef] [PubMed]

24. Crawford, I.A. Lunar resources: A Review. Prog. Phys. Geogr. 2015, 39, 137-167. [CrossRef]

25. Crawford, I.A.; Anand, M.; Cockell, C.S.; Falcke, H.; Green, D.A.; Jaumann, R.; Wieczorek, M.A. Back to the Moon: The scientific rationale for resuming lunar surface exploration. Planet. Space Sci. 2012, 74, 3-14. [CrossRef]

26. Duke, M.B.; Gaddis, L.R.; Taylor, G.J.; Schmitt, H.H. Development of the Moon. In New Views on the Moon; Jolliff, B., Wieczorek, M., Shearer, C., Neal, C., Eds.; Mineralogical Society of America: Chantilly, VA, USA, 2006; Volume 60. 
27. Aldridge, E.C.; Fiorina, C.S.; Jackson, M.P.; Leshin, L.A.; Lyles, L.L.; Spudis, P.D.; Tyson, N.D.; Walker, R.S.; Zuber, M.T. A Journey to Inspire, Innovate and Discover, Report of the President's Commission on Implementation of United States Space Exploration Policy; U.S. Government Printing Office: Washington, DC, USA, 2004.

28. Carpenter, J.; Fisackerly, R.; Houdou, B. Establishing lunar resource viability. Space Policy 2016, 37, 52-57. [CrossRef]

29. Chamberlain, P.G.; Taylor, L.A.; Podnieks, E.R.; Miller, R.J. A review of possible mining applications in space. In Resources of Near-Earth Space; Lewis, J.S., Matthews, M.S., Guerrieri, M.L., Eds.; University of Arizona Press: Tucson, AZ, USA, 1992; pp. 51-68.

30. Shishko, R.; Fradet, R.; Saydam, S.; Tapia-Cortez, C.; Dempster, A.; Coulton, J.; Do, S. An Integrated Economics Model for ISRU in Support of a Mars Colony-Initial Results Report. In Proceedings of the 10th Symposium on Space Resource Utilization, AIAA SciTech Forum (AIAA 2017-0422), Grapevine, TX, USA; 2015. Available online: https:/ / arc.aiaa.org/doi/pdf/10.2514/6.2017-0422 (accessed on 6 August 2017).

31. Wang, K.-T.; Lemouhna, P.N.; Tang, Q.; Li, W.; Cui, X.-M. Lunar regolith can allow the synthesis of cement materials with near-zero water consumption. Gondwana Res. 2017, 44, 1-6. [CrossRef]

32. ASI; BNSC; CNES; CNSA; CSA; CSIRO; DLR; ESA; ISRO; JAXA; KARL; NASA; NSAU; Roscosmos. The Global Exploration Strategy: The Framework for Coordination, 2007. Available online: https:/ /www.nasa.gov/pdf/296751main_GES_framework.pdf (accessed on 1 May 2017).

33. Wood, J.A.; Dickey, J.S.; Marvin, U.B.; Powell, B.M. Lunar anorthosites and a geophysical model of the Moon. In Proceedings of the Apollo 11 Lunar Science Conference, Houston, TX, USA, 5-8 January 1970; Pergamon: New York, NY, USA, 1970; pp. 965-988.

34. Smith, J.V.; Andersen, A.T.; Newton, R.C.; Olsen, E.J.; Crewe, A.V.; Isaacson, M.S.; Johnson, D.; Wyllie, P.J. Petrologic history of the Moon inferred from petrography, mineralogy, and petrogenesis of the Apollo 11 rocks. In Proceedings of the Apollo 11 Lunar Science Conference, Houston, TX, USA, 5-8 January 1970; Pergamon Press: New York, NY, USA, 1970; pp. 897-926.

35. Taylor, S.R.; Jakes, P. The geochemical evolution of the moon. Proceedings of 5th Lunar Science Conference, Houston, TX, USA, 18-22 March 1974; pp. 1287-1305.

36. Taylor, S.R. Lunar Science: A Post-Apollo View; Pergamon Press: New York, NY, USA, 1975; p. 372.

37. Taylor, S.R. Structure and evolution of the moon. Nature 1979, 281, 105-110. [CrossRef]

38. Shirley, D.N. A partially molten magma ocean model. J. Geophys. Res. 1983, 88, A519-A527. [CrossRef]

39. Warren, P.W. The lunar magma ocean concept and lunar evolution. Ann. Rev. Earth Planet. Sci. 1985, 13, 201-240. [CrossRef]

40. Heiken, G.H.; Vaniman, D.T.; French, B.M. (Eds.) Lunar Sourebook a User's Guide to the Moon; Cambridge University Press and the Lunar Planetary Institute: Cambridge, UK, 1991; 736p.

41. Snyder, G.A.; Taylor, L.A.; Neal, C.R. A chemical model for generating the sources of mare basalts: combined equilibrium and fractional crystallization of the lunar magmasphere. Geochim. Cosmochim. Acta 1992, 56, 3809-3823. [CrossRef]

42. Papike, J.J.; Ryder, G.; Shearer, C.K. Lunar Materials. In Planetary Materials, Reviews in Mineralogy; Papike, J.J., Ed.; Mineralogical Society of America: Washington, DC, USA, 1998; Volume 36, pp. 5.1-5.23.

43. Jolliff, B.L.; Wieczorek, M.A.; Shearer, C.K.; Neal, C.R. (Eds.) New Views of the Moon; Reviews in Mineralogy and Geochemistry, Mineralogical Society of America: Chantilly, VA, USA, 2006; Volume 60, p. 721.

44. Longhi, J. Petrogenesis of the picritic mare magmas: on constraints on the extent of early lunar differentiation. Geochim. Cosmochim. Acta 2006, 70, 5919-5934. [CrossRef]

45. Touboul, M.; Kleine, T.; Bourdon, B.; Palme, H.; Wieler, R. Late formation and prolonged differentiation of the Moon inferred from W isotopes in lunar metals. Nature 2007, 450, 1206-1209. [CrossRef] [PubMed]

46. Halliday, A.N. A young Moon-forming giant impact 70-110 million years ago accompanied by late-stage mixing, core formation and degassing of the Earth. Philos. Trans. R. Soc. 2008, 366, 4163-4181. [CrossRef] [PubMed]

47. Brandon, A.D.; Lapen, T.J.; Debaille, V.; Beard, B.K.; Rankenburg, K.; Neal, C. Re-evaluating ${ }^{142} \mathrm{Nd} /{ }^{144} \mathrm{Nd}$ in lunar mare basalts with the implications for the early evolution and bulk Sm/Nd of the Moon. Geochim. Cosmochim. Acta 2009, 73, 6421-6445. [CrossRef]

48. Kleine, T.; Touboul, M.; Bourdon, B.; Nimmo, F.; Mezger, K.; Palme, H.; Jacobsen, S.B.; Yin, Q.-Z.; Halliday, A.N. Hf-W chronology of the accretion and early evolution of asteroids and terrestrial planets. Geochim. Cosmochim. Acta 2009, 73, 5150-5188. [CrossRef] 
49. Borg, L.E.; Connelly, J.N.; Boyet, M.; Carlson, R.W. Chronological evidence that the Moon is either young or did not have a global magma ocean. Science 2011, 477, 70-72. [CrossRef] [PubMed]

50. Elardo, S.M.; Draper, D.S.; Shearer, C.K. Lunar magma ocean crystallization revisited: bulk composition, early cumulate mineralogy and the source regions of the Mg-suite. Geochim. Cosmochim. Acta 2011, 75, 3024-3045. [CrossRef]

51. Elkins-Tanton, L.T. Magma oceans in the inner solar system. Ann. Rev. Earth Planet. Sci. 2012, 40, 113-139. [CrossRef]

52. Jacobson, S.A.; Mobirdelli, A.; Rayond, S.N.; O’Brien, D.P.; Walsh, K.J.; Rubie, D.C. Highly siderophile elements in Earth's mantle as a clock for the Moon-forming impact. Nature 2014, 508, 84-87. [CrossRef] [PubMed]

53. McLeod, C.L.; Brandon, A.D.; Armytage, R.M.G. Constraints on the formation age and evolution of the Moon from ${ }^{142} \mathrm{Nd}-{ }^{143} \mathrm{Nd}$ systematics of Apollo 12 basalts. Earth Planet. Sci. Lett. 2014, 396, 179-189. [CrossRef]

54. McLeod, C.L.; Brandon, A.D.; Fernandes, V.A.; Peslier, A.H.; Fritz, J.; Lapen, T.; Shafer, J.T.; Butcher, A.R.; Irving, A.J. Constraints on formation and evolution of the lunar crust from feldspathic granultic breccias NWA 3163 and 4881. Geochim. Cosmochim. Acta 2016, 187, 350-374. [CrossRef]

55. Borg, L.E.; Gaffney, A.M.; Shearer, C.K. A review of lunar chronology revealing a preponderance of 4.34-4.37 Ga ages. Meteorit. Planet. Sci. 2015, 50, 715-732. [CrossRef]

56. Boyce, J.W.; Treiman, A.H.; Guan, Y.; Ma, C.; Eiler, J.M.; Gross, J.; Greenwood, J.P.; Stolper, E.M. The chlorine isotope fingerprint of the lunar magma ocean. Sci. Adv. 2015, 1, 1-8. [CrossRef] [PubMed]

57. Barr, A.C. On the origin of the Earth's Moon. J. Geophys. Res. Planets 2016, 121, 1573-1601. [CrossRef]

58. Sivakumar, V.; Neekakantan, R.; Santosh, M. Lunar surface mineralogy using hyperspectral data: Implications for primordial crust in the Earth-Moon system. Geosci. Front. 2017, 8, 457-465. [CrossRef]

59. Sun, C.; Graff, M.; Liang, Y. Trace element partitioning between plagioclase and silicate melt: The importance of temperature and plagioclase composition, with implications for terrestrial and lunar magnetism. Geochim. Cosmochim. Acta 2017, 206, 273-295. [CrossRef]

60. Google LUNAR XPRIZE, 2017. Available online: http:/ / lunar.xprize.org/ (accessed on 4 June 2017).

61. Moon Express. 2016. Available online: http://www.moonexpress.com/files/moon-express-press-kit.pdf (accessed on 4 June 2017).

62. Caminiti, S. The Billionaire's Race to Harness the Moon's Resources. Available online: http://www.cnbc. com/2014/04/02/the-global-race-to-harness-the-Moon $\backslash \mathrm{T} 1 \backslash$ textquoterights-resources.html (accessed on 5 August 2017).

63. Goins, N.R.; Dainty, A.M.; Toksoz, M.N. Lunar seismology: The internal structure of the Moon. J. Geophys. Res. 1981, 86, 5061-5074. [CrossRef]

64. Wieczorek, M.A.; Jolliff, B.L.; Khan, A.; Pritchard, M.E.; Weiss, B.P.; Williams, J.G.; Hood, L.L.; Righter, K.; Neal, C.R.; Shearer, C.K.; et al. The Constitution and Structure of the Lunar Interior. Rev. Mineral. Geochem. 2006, 60, 221-364. [CrossRef]

65. Weber, R.C.; Lin, P.-Y.; Garnero, E.J.; Williams, Q.; Lognonne, P. Seismic Detection of the Lunar Core. Science 2011, 331, 309-312. [CrossRef] [PubMed]

66. Jaumann, R.; Hiesinger, H.; Anand, M.; Crawford, I.A.; Wagner, R.; Sohl, F.; Jolliff, B.L.; Scholten, F.; Knapmeyer, M.; Hoffman, H.; et al. Geology, geochemistry and geophysics of the Moon: Status of current understanding. Planet. Space Sci. 2012, 74, 15-41. [CrossRef]

67. Haskin, L.A.; Colson, R.O.; Vaniman, D.T.; Gillett, S.L. A geochemical assessment of possible lunar ore formation. In Resources of Near-Earth Space; Lewis, J.S., Matthews, M.S., Guerrieri, M.L, Eds.; University of Arizona Press: Tucson, AZ, USA, 1993; 977p.

68. Solomon, S.C.; Toksoz, M.N. Internal Constitution and Evolution of the Moon. Phys. Earth Planet. Inter. 1973, 7, 15-38. [CrossRef]

69. Elkins-Tanton, L.T.; Burgess, S.; Yin, Q.-Z. The lunar magma ocean: Reconciling the solidification process with lunar petrology and geochronology. Earth Planet. Sci. Lett. 2011, 304, 326-336. [CrossRef]

70. McLeod, C.L. Lunar Magma Ocean, Size. In Encyclopedia of Lunar Science; Cudnik, B., Ed.; Springer: New York, NY, USA, 2016. [CrossRef]

71. Wieczorek, M.A.; Neumann, G.A.; Nimmo, F.; Kiefer, W.S.; Taylor, G.J.; Melosh, H.J.; Phillips, R.J.; Solomon, S.C.; Andrews-Hanna, J.C.; Asmar, S.W.; et al. The Crust of the Moon as Seen by GRAIL. Science 2013, 339, 671-675. [CrossRef] [PubMed] 
72. Petro, N.E.; Jolliff, B.L. Thin Crust in the South Pole Aitken Basin and Samples from the Mantle? Implications for the South Pole-Aitken Basin Sampling in light of Recent GRAIL Results. In Proceedings of the 44th Lunar Planetary Science Conference, Woodlands, TX, USA, 18-22 March 2013; p. 2724.

73. Green, D.H.; Ringwood, A.E. The stability fields of aluminous pyroxene peridotite and garnet peridotite. Earth Planet. Sci. Lett. 1967, 3, 151-160. [CrossRef]

74. Longhi, J. A model of early lunar differentiation. In Proceedings of the 11st Lunar and Planetary Science Conference, Houston, TX, USA, 17-21 March 1980; pp. 289-315.

75. Shearer, C.K.; Papike, J.J. Magmatic evolution of the Moon. Am. Mineral. 1999, 84, 1469-1494. [CrossRef]

76. Hiesinger, H.; Jaumann, R.; Neukum, G.; Head, J.W., III. Ages of mare basalts on the lunar nearside. J. Geophys. Res. 2000, 105, 29239-29275. [CrossRef]

77. Braden, S.E.; Stopar, J.S.; Robinson, M.S.; Lawrence, S.J.; van der Bogert, C.H.; Hiesenger, H. Evidence for basaltic volcanism on the Moon within the past 100 million years. Nat. Geosci. 2014, 7, 787-791. [CrossRef]

78. Green, D.H.; Ringwood, A.E.; Ware, N.G.; Hibberson, A.; Kiss, E. Experimental petrology and petrogenesis of Apollo 12 basalts. In Proceedings of the 2nd Lunar Science Conference, Houston, TX, USA, 11-14 January 1971; pp. 601-615.

79. Green, D.H.; Ware, N.G.; Hibberson, A.; Major, A. Experimental petrology of Apollo 12 mare basalts, Part 1, sample 12009. Earth Planet. Sci. Lett. 1971, 13, 85-96. [CrossRef]

80. Philpotts, J.A.; Schnetzler, C.C.; Nava, D.D.; Bottino, M.L.; Fullagar, P.D.; Thomas, H.H.; Schumann, S.; Kouns, C.W. Apollo 14: some geochemical aspects. Proceedings of Third Lunar Planetary Science Conference, Houston, TX, USA, 10-13 January 1972; The MIT Press; pp. 1293-1305. Available online: http://adsabs. harvard.edu/full/1972LPSC....3.1293P (accessed on 28 May 2017).

81. Haskin, L.A.; Lindstrom, M.M.; Salpas, P.A.; Lindstrom, D. On compositional variations among lunar anorthosites. In Proceedings of the 12th Lunar Science Conference, Houston, TX, USA, 16-20 March 1981; pp. 41-66.

82. Morse, S.A. Adcumulus growth of anorthosite at the base of the lunar crust. In Proceedings of the 13th Lunar and Planetary Science Conference, Houston, TX, USA, 15-19 March 1982; pp. A10-A18.

83. Ryder, G. Lunar anorthosite 60025, the petrogenesis of lunar anorthosites, and the bulk composition of the Moon. Geochem. Cosmochim. Acta 1982, 46, 1591-1601. [CrossRef]

84. Longhi, J. Origin of Picritic Green Glass Magmas by Polybaric Fractional Fusion. Proc. Lunar Planet. Sci. 1992, 22, 343-353.

85. Warren, P.W.; Wasson, J.T. Compositional-petrographic investigation of pristine nonmare rocks. In Proceedings of the 9th Lunar and Planetary Science Conference, Houston, TX, USA, 13-17 March 1978; pp. 185-217.

86. Yanhao, L.; Tronche, E.J.; Steenstra, E.S.; van Westrenen, W. Experimental constraints on the solidification of a nominally dry lunar magma ocean. Earth Planet. Sci. Lett. 2017, 471, 104-116.

87. Alibert, C.; Norman, M.D.; McCulloch, M.T. An ancient Sm-Nd age for a ferroan noritic anorthosite clast from lunar breccia 67016. Geochim. Cosmochim. Acta 1994, 58, 2921-2926. [CrossRef]

88. Borg, L.E.; Gaffney, A.M.; Shearer, C.K.; DePaolo, D.J.; Hutcheon, I.D.; Owens, T.L.; Ramon, E.; Brennecka, G. Mechanisms for incompatible-element enrichment on the Moon deduced from the lunar basaltic meteorite Northwest Africa 032. Geochim. Cosmochim. Acta 2009, 73, 3963-3980. [CrossRef]

89. Meyer, J.; Elkins Tanton, L.T.; Wisdom, J. Coupled thermal-orbital evolution of the early Moon. Icarus 2010, 208, 1-10. [CrossRef]

90. Taylor, D.J.; McKeegan, K.D.; Harrison, T.M. Lu-Hf zircon evidence for rapid lunar differentiation. Earth Planet. Sci. Lett. 2009, 279, 157-264. [CrossRef]

91. Gaffney, A.M.; Borg, L.E. A Young Age for KREEP Formation Determined from Lu-Hf Isotope Systematics of KREEP Basalts and Mg-Suite Samples. In Proceedings of the 44th Lunar and Planetary Science Conference, Woodlands, TX, USA, 18-22 March 2013; p. 1719.

92. Smith, J.V.; Steele, I.M. Lunar mineralogy: A heavenly detective story. Part II. Am. Mineral. 1976, 61, 1059-1116.

93. Meyer, C. NASA Lunar Petrographic Educational Thin Section Set. 2003. Available online: https://curator. jsc.nasa.gov/lunar/letss/mineralogy.pdf (accessed on 18 March 2017).

94. Meyer, C. Lunar Sample Compendium; Lunar Planetary Institute: Houston, TX, USA, 2009.

95. Frondel, J.W. Lunar Mineralogy; Wiley-Interscience: New York, NY, USA, 1975; pp. 84-87. 
96. Yazawa, Y.; Yamaguchi, A.; Takeda, H. Lunar Minerals and Their Resource Utilization with Particular Reference to Solar Power Satellite and Potential Roles for Humic substances for Lunar Agriculture. In Moon, Prospective Energy and Material Resources; Badescu, V., Ed.; Springer: New York, NY, USA, 2012; 771p.

97. Dixon, J.R.; Papike, J.J. Petrology of anorthosites from the Descartes region of the moon: Apollo 16. In Proceedings of the 6th Lunar Science Conference, Houston, TX, USA, 17-21 March 1975; pp. 263-291.

98. James, O.B.; Lindstrom, M.M.; McGee, J.J. Lunar ferroan anorthosite 60025: Petrology and chemistry of mafic lithologies. In Proceedings of the 21st Lunar Planetary Science Conference, Houston, TX, USA, 12-16 March 1990; Lunar Planetary Institute: Houston, TX, USA.

99. Brown, G.M.; Emeleus, C.H.; Holland, G.J.; Peckett, A.; Phillips, R. Mineral-chemical variations in Apollo 14 and Apollo 15 basalts and granitic fractions. In Proceedings of the 3rd Lunar Science Conference, Houston, TX, USA, 10-13 January 1972; pp. 147-157.

100. Papike, J.J.; Hodges, F.N.; Bence, A.E.; Cameron, M.; Rhodes, J.M. Mare basalts: Crystal chemistry, mineralogy and petrology. Rev. Geophys. Space Phys. 1976, 14, 475-540. [CrossRef]

101. McGee, P.E.; Warner, J.L.; Simonds, C.H. Introduction to the Apollo Collections. Part I: Lunar Igneous Rocks; Curators Office, JSC, 1977; Available online: http:/ / www.lpi.usra.edu/lunar/surface/apolloCollectionsPartI. pdf (accessed on 28 May 2017).

102. Lunar Sample Atlas. Available online: http://www.lpi.usra.edu/lunar/samples/atlas/thin_sections/ (accessed on 12 March 2017).

103. Warren, P.H.; Wasson, J.T. The Origin of KREEP. Rev. Geophys. Space Phys. 1979, 17, 73-88. [CrossRef]

104. Shearer, C.K.; Hess, P.C.; Wieczorek, M.A.; Prichard, M.E.; Parmentier, E.M.; Borg, L.E.; Longhi, J.; Elkins-Tanton, L.T.; Neal, C.R.; Antonenko, I.; et al. Thermal and Magmatic Evolution of the Moon. Rev. Mineral. Geochem. 2006, 60, 365-518. [CrossRef]

105. Lawrence, D.J.; Feldman, W.C.; Barraclough, B.L.; Elphic, R.C.; Maurice, S.; Binder, A.B.; Miller, M.C.; Prettyman, T.H. High resolution measurements of absolute thorium abundances on the lunar surface from the Lunar Prospector gamma-ray spectrometer. Geophys. Res. Lett. 1999, 26, 2681-2684. [CrossRef]

106. Haskin, L.A.; Gillis, J.J.; Korotev, R.L.; Jolliff, B.L. The Materials of the lunar Procellarum KREEP Terrane: A synthesis of data from geomorphological mapping, remote-sensing, and sample analysis. J. Geophys. Res. 2000, 105, 20403-20415. [CrossRef]

107. Jolliff, B.L.; Gillis, J.J.; Haskin, L.A.; Korotev, R.L.; Wieczorek, M.A. Major lunar crustal terranes: Surface expressions and crust-mantle origins. J. Geophys. Res. Planets 2000, 105, 4197-4216. [CrossRef]

108. Global Map of the Element Thorium. Available online: https://solarsystem.nasa.gov/galleries/global-mapof-the-element-thorium (accessed 21 August 2017).

109. Wieczorek, M.A.; Phillips, R.J. Lunar multi-ring basins and the cratering process. Icarus 1999, 139, $246-259$. [CrossRef]

110. Lawrence, D.J.; Feldman, W.C.; Barraclough, B.L.; Binder, A.B.; Elphic, R.C.; Maurice, S.; Miller, M.C.; Prettyman, T.H. Thorium abundances on the lunar surface. J. Geophys. Res. 2000, 105, 20307-20331. [CrossRef]

111. Zou, Y.; Xu, L.; Ouyang, Z. KREEP Rocks. Chin. J. Geochem. 2004, 23, 65-70.

112. Neal, C.L.; Taylor, L.A. Definition of a Pristine, Unadulterated urKREEP Composition Using the "K-FRAC/REEP-FRAC" Hypothesis. Abstracts of the Lunar and Planetary Science Conference. 1989, Volume 20, pp. 772-773. Available online: http:/ /adsabs.harvard.edu/full/1989LPI....20..772N (accessed on 27 May 2017).

113. Neal, C.L.; Taylor, L.A. Metasomatic products of the lunar magma ocean: The role of KREEP dissemination. Geochim. Cosmochim. Acta 1989, 53, 529-541. [CrossRef]

114. Thompson, R.N. British Tertiary volcanic province. Scott. J. Geol. 1982, 18, 49-107. [CrossRef]

115. Lindstrom, M.M.; Knapp, S.A.; Shervais, J.A.; Taylor, L.A. Magnesian anorthosites and associated troctolites and dunite in Apollo 14 breccias. In Proceedings of the 15th Lunar and Planetary Science Conference, Houston, TX, USA, 12-16 March 1984; pp. C41-C49.

116. Rudnick, R.L.; Gao, S. Composition of the Continental Crust. Treatise Geochem. 2003, 3, 1-64.

117. Warren, P.H.; Jerde, E.A.; Kalleymeyn, G.W. Pristine moon rocks: A “large" felsite and metal-rich ferroan anorthosite. In Proceedings of the 17th Lunar and Planetary Science Conference, Houston, TX, USA. 
118. Jolliff, B.L.; Wadhwa, M. The distribution of Rare Earth Elements between Lunar apatite and whitlockite. In Proceedings of the 23rd Lunar and Planetary Science Conference, Houston, TX, USA, 16-20 March 1992; pp. 625-626.

119. Kartashov, P.M.; Bogatikov, O.A.; Mokhov, A.V.; Gorshkov, A.I.; Ashikhmina, N.A.; Magazina, L.O.; Koporulina, E.V. Lunar Monazites. In Doklady Earth Sciences; MAIK Nauka/Interperiodica, 2006; Volume 407A, pp. 498-502. Available online: https://link.springer.com/article/10.1134/S1028334X06030342 (accessed on 21 August 2017).

120. Jolliff, B.L.; Hughes, J.M.; Freeman, J.J.; Ziegler, R.A. Crystal chemistry of lunar merrillite and comparison to other meteoritic and planetary suites of whitlockite and merrillite. Am. Mineral. 2006, 91, 1583-1595. [CrossRef]

121. Jolliff, B.L. Fragments of Quartz Monzodiorite and Felsite in Apollo 14 Soil Particles. In Proceedings of the Lunar and Planetary Science Conference, Houston, TX, USA, 12-16 March 1990; Volume 21, pp. 101-118.

122. Jolliff, B.L. Large-Scale Separation of K-frac and REEP-frac in the source Regions of Apollo Impact-Melt Breccias, and a Revised Estimate of the KREEP Composition. Int. Geol. Rev. 1998, 40, 916-935. [CrossRef]

123. Meyer, C.; Yang, S.V. Tungsten-bearing yttrobetafite in lunar granophyre. Am. Mineral. 1988, 73, 1420-1425.

124. Ramdohr, P.; El Gorsey, A. Opaque minerals of the lunar rocks and dust from Mare Tranquillitatis. Science 1970, 167, 615-618. [CrossRef] [PubMed]

125. Cameron, E.N. Opaque minerals in certain lunar rocks from Apollo 11. In Proceedings of the Apollo 11 Lunar Science Conference, Houston, TX, USA, 5-8 January 1970; pp. 221-245.

126. Lovering, J.F.; Wark, D.A.; Reid, A.F.; Ware, N.G.; Keil, K.; Prinz, M.; Bunch, T.E.; El Gorsey, A.; Ramdohr, P.; Brown, G.M.; et al. Tranquillityite: A new silicate mineral from Apollo 11 and Apollo 12 basaltic rocks. In Proceedings of the Lunar Science Conference, Houston, TX, USA, 11-14 January 1971; Volume 2, pp. $39-45$.

127. Rasmussen, B.; Fletcher, I.R.; Gregory, C.J.; Muhling, J.R.; Suvorova, A.A. Tranquillityite: The last lunar mineral comes down to Earth. Geology 2012, 40, 83-86. [CrossRef]

128. Haskin, L.A.; Warren, P. Lunar Chemistry. In The Lunar Sourcebook: A User's Guide to the Moon; Cambridge University Press: Cambridge, UK, 1991; pp. 357-474.

129. McKay, D.S.; Heiken, G.; Basu, A.; Blanford, G.; Simon, S.; Reedy, R.; French, B.M.; Papike, J. The lunar regolith. In Lunar Sourcebook; Heiken, G.H., Vaniman, D.T., French, B.M., Eds.; Cambridge University Press: Cambridge, UK, 1991; pp. 285-356.

130. Blair, B. Quantitative Approaches to Lunar Economic Analysis. In Proceedings of the Annual Meeting of the Lunar Exploration Analysis Group (LEAG), Houston, TX, USA; 2009. Available online: http:/ /www.lpi. usra.edu/meetings/leag2009/presentations/Day-1\%20PM/02-15_Blair.pdf (accessed on 6 August 2017).

131. Santiago-Maldonado, E.; Gleaton, J.; Devor, R.; Captain, J. Creating Methane from Plastic: Recycling at a Lunar Outpost. In Proceedings of the 48th AIAA Aerospace Sciences Meeting including the New Horizons Forum and Aerospace Exposition, Orlando, FL, USA, 4-7 January 2010; American Institute of Aeronautics and Astronautics: Reston, VA, USA, 2010; Volume 21, pp. 18271-18278.

132. Hintze, P.E.; Quintana, S. Building a Lunar or Martian Launch Pad with In Situ Materials: Recent Laboratory and Field Studies. J. Aerosp. Eng. 2013, 26, 134-142. [CrossRef]

133. Schrunk, D.; Sharp, B.; Cooper, B.; Thangavelu, M. The Moon: Resources, Future Development, and Settlement; Springer: Chichester, UK, 2008.

134. Anand, M.; Crawford, I.A.; Balat-Pichelin, M.; Abanades, S.; van Westrenen, W.; Péraudeau, G.; Jaumann, R.; Seboldt, W. A brief review of chemical and mineralogical resources on the Moon and likely in situ resource utilization (ISRU) applications. Planet. Space Sci. 2012, 74, 42-48. [CrossRef]

135. Fegley, B.; Swindle, T.D. Lunar volatiles: Implications for lunar resource utilization. In Resources of Near Earth Space; Lewis, J., Matthews, M.S., Guerrieri, M.L., Eds.; Tucson University Press: Tucson, AZ, USA, 1993; pp. 367-426.

136. Fa, W.; Jin, Y.-Q. Quantitative estimation of helium-3 spatial distribution in the lunar regolith layer. Icarus 2007, 190, 15-23. [CrossRef]

137. Feldman, W.C.; Maurice, S.; Binder, A.B.; Barraclough, B.L.; Elphic, R.C.; Lawrence, D.J. Fluxes of fast and epithermal neutrons from Lunar Prospector: Evidence for water ice at the lunar poles. Science 1998, 281, 1496-1500. [CrossRef] [PubMed] 
138. Feldman, W.C.; Maurice, S.; Lawrence, D.J.; Little, R.C.; Lawson, S.L.; Gasnault, O.; Wiens, R.C.; Barraclough, B.L.; Elphic, R.C.; Prettyman, T.H.; et al. Evidence for water ice near the lunar poles. J. Geophys. Res. 2011, 106, 23231-23252. [CrossRef]

139. Colaprete, A.; Schultz, P.; Heldmann, J.; Wooden, D.; Shirley, M.; Ennico, K.; Hermalyn, B.; Marshall, W.; Ricco, A.; Elphic, R.C.; et al. Detection of Water in the LCROSS Ejecta Plume. Science 2010, 330, 463-468. [CrossRef] [PubMed]

140. USGS. 2016. Available online: https://water.usgs.gov/edu/qa-home-percapita.html (accessed on 19 March 2017).

141. Taylor, L.A.; Carrier, W.D. Oxygen production on the Moon: An overview and evaluation. In Resources of Near Earth Space; Lewis, J., Matthews, M.S., Guerrieri, M.L., Eds.; Tucson University: Tucson, AZ, USA, 1993.

142. Schwandt, C.; Dimitrov, A.T.; Fray, D.J. High-yield synthesis of multi-walled carbon nanotubes from graphite by molten salt electrolysis. Carbon 2012, 50, 1311-1315. [CrossRef]

143. Benaroya, H.; Mottaghi, S.; Porter, Z. Magnesium as an ISRU-derived resource for lunar structures. J. Aerosp. Eng. 2013, 26, 152-159. [CrossRef]

144. Mottaghi, S.; Benaroya, H. Design of a Lunar Surface Structure. I: Design Configuration and Thermal Analysis. J. Aerosp. Eng. 2015, 28, 0401405. [CrossRef]

145. NASA. Metals from Regolith. 2012. Available online: https://isru.nasa.gov/MetalsfromRegolith.html (accessed on 7 August 2017).

146. Lucey, P.G.; Taylor, G.J.; Malaret, E. Abundance and distribution of iron on the Moon. Science 1995, 268, 1150-1153. [CrossRef] [PubMed]

147. Meyers, C.; Toutanji, H. Analysis of Lunar-Habitat Structure Using Waterless Concrete and Tension glass Fibers. J. Aerosp. Eng. 2007, 20, 220-226. [CrossRef]

148. Masafumi, I.; Gertsch, L. Excavation of Lunar Regolith with Large Grains by Rippers for Improved Excavation Efficiency. J. Aerosp. Eng. 2013, 26, 97-104.

149. Wilhelm, S.; Curbach, M. Review of possible mineral materials and production techniques for a building material on the moon. Struct. Concr. 2014, 15, 419-428. [CrossRef]

150. Turkevich, A. Average chemical composition of the lunar surface. In Proceedings of the 4th Lunar Science Conference, Houston, TX, USA, 5-8 March 1973; Volume 2, pp. 1119-1168.

151. Papike, J.J.; Simon, S.B.; Laul, J.C. Lunar Regolith: Chemistry, Mineralogy, and Petrology. Rev. Geophys. 1982, 20, 761-826. [CrossRef]

152. Lucey, P.G.; Korotev, R.L.; Gillis, J.J.; Taylor, L.A.; Lawrence, D.; Campbell, B.A.; Elphic, R.; Feldman, B.; Hood, L.L.; Hunten, D.; et al. Understanding the lunar surface and space-Moon interaction. Rev. Mineral. Geochem. 2006, 60, 82-219. [CrossRef]

153. Ceccanti, F.; Dini, E.; De Kestelier, X.; Colla, V.; Pambaguian, L. 3D printing technology for a moon outpost exploiting lunar soil. In Proceedings of the 61st International Astronautical Congress, Prague, Czech Republic, 27 September-1 October 2010; Available online: http://esmat.esa.int/Publications/Published_ papers/IAC-10-D3.3.5.pdf (accessed on 23 August 2017).

154. Cesaretti, G.; Dini, E.; De Kestelier, X.; Colla, V.; Pambaguian, L. Building components for an outpost on the Lunar soil by means of a novel 3D printing technology. Acta Astron. 2014, 93, 430-450. [CrossRef]

155. Norman, M.D. The composition and thickness of the crust of Mars estimated from rare earth elements and neodymium-isotopic compositions of Martian meteorites. Meteorit. Planet. Sci. 1999, 34, 439-449. [CrossRef]

156. An up-to-date List of Martian Meteorites. Available online: http://www.imca.cc/mars/martian-meteoriteslist.htm (accessed on 21 August 2017).

157. List of Lunar Meteorites. Available online: http://meteorites.wustl.edu/lunar/moon_meteorites_list_alpha. htm (accessed on 21 August 2017).

158. Apollo Missions. Available online: http://www.lpi.usra.edu/lunar/missions/apollo/ (accessed on 21 August 2017).

159. Taylor, G.J. A Primordial and Complicated Ocean of Magma on Mars. Planetary Science Research Discoveries, 2006. Available online: http://www.psrd.hawaii.edu/Mar06/mars_magmaOcean.html (accessed on 7 August 2017).

160. Harper, C.L.; Nyquist, L.E.; Bansal, B.; Wiesmann, H.; Shih, C.-Y. Rapid accretion and early differentiation of Mars as indicated by ${ }^{142} \mathrm{Nd} /{ }^{144} \mathrm{Nd}$ in SNC meteorites. Science 1995, 267, 213-216. [CrossRef] [PubMed] 
161. Borg, L.E.; Nyquist, L.E.; Taylor, L.A.; Wiesmann, H.; Shih, C.-Y. Constraints on Martian differentiation processes from $\mathrm{Rb}-\mathrm{Sr}$ and Sm-Nd isotopic analyses of the basaltic shergottite QUE 94201. Geochim. Cosmochim. Acta 1997, 61, 4915-4931. [CrossRef]

162. Lee, D-C.; Halliday, A.N. Core formation on Mars and differentiated asteroids. Nature 1997, 388, 854-857. [CrossRef]

163. Halliday, A.N.; Wänke, H.; Birck, J.-L.; Clayton, R.N. The Accretion, Composition and Early Differentiation of Mars. Space Sci. Rev. 2001, 96, 197-230. [CrossRef]

164. Elkins-Tanton, L.T.; Parmentier, E.M.; Hess, P.C. Magma ocean fractional crystallization and cumulate overturn in terrestrial planets: Implications for Mars. Meteorit. Planet. Sci. 2003, 38, 1753-1771. [CrossRef]

165. Elkins-Tanton, L.T.; Hess, P.C.; Parmentier, E.M. Possible formation of ancient crust on Mars through magma ocean processes. J. Geophys. Res. 2005, 110, E12S01. [CrossRef]

166. Foley, C.N.; Wadhwa, M.; Borg, L.E.; Janney, P.E.; Hines, R.; Grove, T.L. The early differentiation history of Mars from ${ }^{182} \mathrm{~W}_{-}{ }^{142} \mathrm{Nd}$ isotope systematics in the SNC meteorites. Geochim. Cosmochim. Acta 2005, 69, 4557-4571. [CrossRef]

167. Solomon, S.C.; Aharonson, O.; Aurnou, J.M.; Banerdt, B.W.; Carr, M.H.; Dombard, A.J.; Frey, H.V.; Golombek, M.P.; Hauck, S.A., II; Head, J.W., III; et al. New Perspectives on American Mars. Science 2005, 307, 1214-1220. [CrossRef] [PubMed]

168. Borg, L.E.; Draper, D.S. A petrogenetic model for the origin and compositional variation of the Martian basaltic meteorites. Meteorit. Planet. Sci. 2003, 38, 1713-1731. [CrossRef]

169. Boynton, W.V.; Taylor, G.J.; Evans, L.G.; Reedy, R.C.; Starr, R.; Janes, D.M.; Kerry, K.E.; Drake, D.M.; Kim, K.J.; Williams, R.M.S.; et al. Concentration of $\mathrm{H}, \mathrm{Si}, \mathrm{Cl}, \mathrm{K}, \mathrm{Fe}$, and $\mathrm{Th}$ in the low- and mid-latitude regions of Mars. J. Geophys. Res. Planets 2007, 112, E12. [CrossRef]

170. Gasnault, O.; Taylor, G.J.; Karunatillake, S.; Dohm, J.; Newsom, H.; Forni, O.; Pinet, P.; Boynton, W.V. Quantitative geochemical mapping of Martian elemental provinces. Icarus 2010, 207, 226-247. [CrossRef]

171. Meslin, P.-Y.; Gasnault, O.; Forni, O.; Schröder, S.; Cousin, A.; Berger, G.; Clegg, S.M.; Lasue, J.; Maurice, S.; Sautter, V.; et al. Soil Diversity and Hydration as Observed by ChemCam at Gale Crater, Mars. Science 2013, 341, 1238670. [CrossRef] [PubMed]

172. McSween, H.Y., Jr.; Taylor, G.J.; Wyatt, M.B. Elemental composition of the Martian Crust. Science 2009, 324, 736-739. [CrossRef] [PubMed]

173. Agee, C.B.; Wilson, N.V.; McCubbin, F.M.; Ziegler, K.; Polyak, V.J.; Sharp, Z.D.; Asmerom, Y.; Nunn, M.H.; Shaheen, R.; Thiemens, M.H.; et al. Unique Meteorite from Early Amazonian Mars: Water-Rich Basaltic Breccia Northwest Africa 7034. Science 2013, 339, 780-785. [CrossRef] [PubMed]

174. Humayun, M.; Nemchin, A.; Zanda, B.; Hewins, R.H.; Grange, M.; Kennedy, A.; Lorand, J.P.; Goepel, C.; Fieni, C.; Pont, S.; et al. Origin and age of the earliest Martian crust from meteorite NWA 7533. Nature 2013, 503, 513-517. [CrossRef] [PubMed]

175. Wittmann, A.; Korotev, R.L.; Jolliff, B.L.; Irving, A.J.; Moser, D.E.; Barker, I.; Rumble, D. Petrography and composition of Martian regolith breccia meteorite Northwest Africa 7475. Meteorit. Planet. Sci. 2015, 50, 326-352. [CrossRef]

176. Liu, Y.; Ma, C.; Beckett, J.R.; Chen, Y.; Guan, Y. Rare-earth element minerals in Martian breccia meteorites NWA 7034 and 7533: Implications for fluid-rock interaction in the Martian crust. Earth Planet. Sci. Lett. 2016, 451, 251-262. [CrossRef]

177. The Martian Meteorite Compendium. Available online: https://curator.jsc.nasa.gov/antmet/mmc/ (accessed on 21 August).

178. Shearer, C.K.; Burger, P.V.; Papike, J.J.; McCubbin, F.M.; Bell, A.S. Crystal chemistry of merrillite from Martian meteorites: Mineralogical recorders of magmatic processes and planetary differentiation. Meteorit. Planet. Sci. 2015, 50, 649-673. [CrossRef]

179. Symes, S.J.; Borg, L.E.; Shearer, C.K.; Irving, A.J. The age of the Martian meteorite Northwest Africa 1195 and the differentiation history of the shergottites. Geochim. Cosmochim. Acta 2008, 72, 1696-1710. [CrossRef]

180. Treiman, A.H. The parent magma of Nakhla (SNC) meteorite, inferred from magmatic inclusions. Geochim. Cosmochim. Acta 1993, 57, 4753-4767. [CrossRef]

181. Treiman, A.H. The nakhlite meteorites: Augite-rich igneous rocks from Mars. Chem. Erde-Geochem. 2005, 65, 203-270. [CrossRef] 
182. Jones, J.H. Isotopic relationships among the shergottites, the nakhlites and Chassigny. In Proceedings of the 4th Lunar and Planetary Science Conference, Houston, TX, USA, 14-18 March 1988; pp. 465-474.

183. Nyquist, L.E.; Shih, C.-Y.; McCubbin, F.M.; Santos, A.R.; Shearer, C.K.; Peng, Z.X.; Burger, P.V.; Agee, C.B. $\mathrm{Rb}-\mathrm{Sr}$ and Sm-Nd isotopic and REE studies of igneous components in the bulk matrix domain of Martian breccia Northwest Africa 7034. Meteorit. Planet. Sci. 2016, 51, 483-498. [CrossRef]

184. Shirai, N.; Ebihara, M. The Magmatism of Mars Inferred From Chemical Composition of Shergottites. In Proceedings of the 37th Lunar and Planetary Science Conference, Woodlands, TX, USA, 13-17 March 2006; p. 1917.

185. Liu, Y.; Ma, C. Monazite in Martian breccia meteorite NWA 7034. In Proceedings of the 8th International Mars Conference, Pasadena, CA, USA, 14-18 July 2014; p. 1250.

186. Liu, Y.; Ma, C. Monazite, chevkinite-perrierite and xenotime in Martian breccia meteorite NWA 7034. In Proceedings of the 46th Lunar Planetary Science Conference, Woodlands, TX, USA, 16-20 March 2015; p. 1287.

187. Dauphaus, N.; Pourmand, A. Thulium anomalies and rare earth element patterns in meteorites and Earth: Nebular fractionation and the nugget effect. Geochim. Cosmochim. Acta 2015, 163, 234-261. [CrossRef]

188. Floss, C.; Crozaz, G. Heterogeneous REE patterns in oldhamite from aubrites: Their nature and origin. Geochim. Cosmochim. Acta 1993, 57, 4039-4057. [CrossRef]

189. Terada, K.; Sano, Y. Ion microprobe U-Pb dating and REE analyses of phosphates in H4-chondrite, Yamato-74371. Geophys. Res. Lett. 2002, 29, 1460. [CrossRef]

190. Reed, S.J.B.; Smith, D.G.W.; Long, J.V.P. Rare earth elements in chondritic phosphates_Implications for ${ }^{244} \mathrm{Pu}$ chronology. Nature 1983, 306, 172-173. [CrossRef]

191. Martínez-Jiménez, M.; Moyano-Cambero, C.E.; Trigo-Rodríguezm, J.M.; Alonso-Azcárate, J.; Jordi, L. Asteroid Mining: Mineral Resources in Undifferentiated Bodies from the Chemical Composition of Carbonaceous Chondrites; Assessment and Mitigation of Asteroid Impact hazards, Astrophysics and Space Science Proceedings; Springer: New York, NY, USA, 2017; pp. 73-101.

192. USGS. Platinum-Group Elements-So Many Excellent Properties. 2014. Available online: https://pubs.usgs. gov/fs/2014/3064/pdf/fs2014-3064.pdf (accessed on 2 August 2017).

193. NASA Approves 2018 Launch of Mars InSight Mission. Available online: https://insight.jpl.nasa.gov/home. cfm (accessed on 21 August 2017).

194. Mars 2020 Mission Overview. Available online: https://mars.nasa.gov/mars2020/mission/overview (accessed on 21 August 2017).

195. Cofield, C. NASA's Mars Plan May Include Yearlong Mission to the Moon. 2017. Available online: https://www.space.com/36781-nasa-yearlong-crew-moon-mission-ahead-of-mars.html (accessed on 6 August 2017).

196. Progress in Defining the Deep Space Gateway and Transport Plan. Available online: https://www.nasa. gov/sites/default/files/atoms/files/nss_chart_v23.pdf (accessed on 21 August 2017).

197. Zubrin, R. The Case for Colonizing Mars. Ad Astra, 1996. Available online: http://www.ifa.hawaii.edu/ $\sim$ meech/a281/handouts/mars_case.pdf (accessed on 6 August 2017).

198. Wall, M. Private Mars Missions: A Red Planet Exploration Roundup. 2016. Available online: https://www.space.com/32721-private-mars-missions-spacex-red-dragon.html (accessed on 6 August 2017).

199. National Aeronautics and Space Administration. Available online: https://solarsystem.nasa.gov/missions/ near/indepth (accessed on 21 August 2017).

200. Asteroid Explorer "HAYABUSA" (MUSES-C). Available online: http://global.jaxa.jp/projects/sat/muses_c/ (accessed on 21 August 2017).

201. Asteroid Explorer "Hayabusa2". Available online: http://global.jaxa.jp/projects/sat/hayabusa2/ (accessed on 21 August 2017).

202. OSIRIS-Rex. Available online: https:/ / www.nasa.gov/osiris-rex (accessed on 21 August 2017).

203. Crawford, I.A. The long-term scientific benefits of a space economy. Space Policy 2016, 37, 58-61. [CrossRef]

(C) 2017 by the authors. Licensee MDPI, Basel, Switzerland. This article is an open access article distributed under the terms and conditions of the Creative Commons Attribution (CC BY) license (http:/ / creativecommons.org/licenses/by/4.0/). 


\title{
Governance and Risk-Value Constructions in Closing Loops of Rare Earth Elements in Global Value Chains
}

\author{
Erika Machacek ${ }^{1, *}$, Jessika Luth Richter ${ }^{2}$ and Ruth Lane ${ }^{3}$ \\ 1 Centre for Minerals and Materials, Geological Survey of Denmark and Greenland (GEUS), \\ Øster Voldgade 10, 1350 Copenhagen, Denmark \\ 2 International Institute for Industrial Environmental Economics (IIIEE), Lund University, Tegnérsplatsen 4, \\ 22100 Lund, Sweden; jessika_luth.richter@iiiee.lu.se \\ 3 Human Geography, School of Social Sciences, Monash University, Wellington Road, Clayton, Victoria 3800, \\ Australia; ruth.lane@monash.edu \\ * Correspondence: em@geus.dk; Tel.: +45-91-33-38-62
}

Received: 31 July 2017; Accepted: 3 October 2017; Published: 24 October 2017

\begin{abstract}
This article addresses a research gap on the challenges—specifically risk and value-connected to realizing the potential for closing loops for rare earth elements (REE). We develop an analytical framework from conceptual elements of the global value chain (GVC) framework and the relational theory of risk to examine several empirical REE industry cases for loop closure. The aim of the paper is to identify how risk-value relationships are constructed by different actors as governance structures form in transactions prior to price setting and how these have impacts on the closure of REE loops. Often, REE loops are not closed, and we find that constructions of the risk-value relationship by industrial actors and by government agencies are unstable as they pursue different motivations, consequently hindering REE loop closure in GVCs. In light of this, we propose that governments mediate against the construction of risk-value relationships by facilitating information on the characteristics of end-of-life materials that qualify these for re-entry into loops.
\end{abstract}

Keywords: rare earth elements; recycling; risk; value; governance; global value chain; transaction

\section{Introduction}

The closure of material loops has come to be central to circular economy debates, but conventional literature hardly discusses the role of risk, especially where low recycling rates indicate the absence of loop closure. More often than not, lack of loop closure is explained in terms of uneconomic processes reflected in price signals, i.e., where prices of an output material per volume of a recycling process are framed as determinants of feasibility as they are compared to primary processing routes. This focus on output-price, however, ignores the dynamics that occur prior to, and in shaping the formation of prices; in particular, the construction of risk and value in the context of transactions between the different actors that participate in the processing segments. Importantly, focus on output rather than process hinders understanding of the supporting mechanisms needed for transiting to a circular economy in which loop closure is one constituent. This paper contributes an analysis of transaction processes in three case studies in which risk and value is constructed in a way that affects loop closure as a first step towards addressing this wider research gap.

At least since the late 1970s, the ideas of circular economy (CE) have been gaining momentum amid concerns about sustainability of material and mineral-dependent lifestyles [1-3]. Pearce and Turner [4] first conceptualized the notion of a CE in ecological economics. Various schools of thought have engaged with it since, including cradle-to-cradle [5], systems thinking [6] and closed-loop approaches to production processes that are integral to industrial ecology in which industrial waste serves as input to another industry [7]. While the understanding of the CE concept has evolved to 
incorporate different features and concepts from the above schools see [8], most share the idea of closed loops [9].

Recently key institutions have advocated for a transition to a $\mathrm{CE}$, which maintains the value of resources, emphasizing durability and circularity, in juxtaposition to the linearity of "take-make-dispose" models [10-14]. The annex to the European Union (EU) Action Plan for the CE for instance, outlines actions for "closing the loop" of product lifecycles through greater recycling and re-use which focuses on recycling target increases for municipal and packaging waste, landfill reduction targets and bans, improvements in definitions and calculations of recycling methods, as well as a focus on industrial symbiosis and economic incentives for producing greener products [15]. In the $\mathrm{EU}$, the CE has also been linked to addressing raw material criticality, and as such critical materials are specifically targeted in the EU's CE Action Plan in Section 5.3 [15].

The European Commission [16] defines raw material criticality as a material that: (1) faces high risk with regard to access (i.e., high supply or environmental risks); and (2) is of high economic importance; such that there is a risk of interruption of supply that could significantly affect the economy. Both the U.S. [17] and EU assess criticality regularly and since 2010 have compiled lists of critical materials which both include rare earth elements (REE), which includes 14 of the 15 lanthanide elements (promethium is not assessed), yttrium and scandium [18]. A subsequent EU assessment [19] further grouped heavy (HREE), light (LREE) and scandium. The EU also launched a European Rare Earths Competency Network (ERECON) to examine how the supply chain for rare earths can be strengthened [20]. One of the working groups within ERECON was specifically focused on EU REE resource efficiency and recycling, highlighting the link with CE strategies that could potentially mitigate such risks through eco-design and closing material loops for critical materials.

An understanding of the materiality of our economies is essential to closing the loop of materials and needs to extend beyond a physical-material focus. The Multi-Stakeholder Platform for a Secure Supply of Refractory Metals in Europe [21] argues that a "valorization of the resources" is required through "coordination and networking between researchers, entrepreneurs and public authorities". However, CE research still largely emphasizes physical flows [22]. A lack of analysis of social and institutional factors constitutes a barrier to further development of the CE [23]. Reck and Grædel [24] stated that social behavior poses one of the limitations for closing material cycles. Without the social dimension, the "how" and "why" of materials flows remain unanswered. These questions need exploring to understand how metal recycling rates can be improved [25].

Studies based on methodologies centering on physical flows cannot explain why material loops are frequently not closed even when there are demonstrated stocks and technological feasibility is proven at lab-scale. What is required is an understanding of the interaction between individual actors in the market [26]. This involves opening up the "black box" of the firm to study "circulation processes" [27]. Barriers and enabling factors for facilitating such flows can then be identified along with the socio-institutional change required to transit to a CE [28]. Risk-value constructions may play a significant role in circulation processes, even more so if these concern the reintroduction of material into processing loops [29]. Lepawsky and Billah [30] make an appeal to the value chain and network scholars to rethink how the capture and creation of value is theorized, proposing that "waste" and "value" be thought relationally.

This paper aims to progress interdisciplinary understanding for scholars, researchers and policy-makers on two aspects. Firstly, it offers an insight into how industrial actors conceive of a risk, an object at risk and form a relationship of risk between the former two at specific segments of a chain/production network. Secondly, it explores how this constructed risk emerges amid governance structures that form in transactions, revealing some of the power dynamics at play. To achieve this, the paper brings the governance structures of the global value chain (GVC) conceptual framework [31] into conversation with the relational theory of risk [32]. This serves to showcase how a focus on transactions in the GVC can bring about useful insights for policy and it reaffirms the social construction 
of risk. In so doing, the paper aims to create an understanding of how and why governance structures and risk communication decisively influence whether or not REE-material loops are closed.

The REE have manifold uses in applications spanning civil, industrial and military use, as components or dopants due to their specific chemical and physical properties. Close to ten different industrial sectors have been delineated that rely on REE input [33]. Among the most widely cited REE uses are permanent magnets, as well as applications that draw on the fluorescent properties of REE, such as (background-) lighting, including in housing but also in electronic equipment that relies on screens, such as computers, smart phones and tablets.

Empirically we examine the relevant GVC segments for three REE recycling case studies. The first case study is that of a proposed chemical separation facility. The second is magnets and the third phosphor powder from EoL lamps (which contain mostly HREE including terbium, europium, yttrium but can also include LREE such as cerium, to a lesser extent). Both magnets and phosphors from lamps are specified as REE priority sectors in ERECON [20]. Our conceptual lens is applied to each in order to explain how industrial actors construct risk at these segments and why loops are not closed despite available, lab-scale tested recycling technology and support from publicly-funded projects. As Balomenos [34] outlined, the EU spent close to 90 million EUR on REE projects over the past five years leading up to 2017. Binnemans et al. [35] cite the improvement of REE recycling as "an absolute necessity" for reasons of their supply risk, economic importance, and the "balance problem" and Binnemans [36] recommends legislative adaptation of recycling directives to account for minor metals. In light of a demonstrated potential for recovery of REE in anthropogenic deposits [37-39], the reason for low REE recycling rates is framed as "a lack of incentives" [37,40-42]. Questions of risk and value have recently begun to be explored in relation to steel and REE respectively [43-47]. However, this is the first paper to apply the relational theory of risk to empirical evidence from the REE industry and to systematically analyze the construction of risk-value relationships in the context of forming governance structures as transactions take place in the GVC of REE.

The paper is structured into six sections. In Section 2, we describe the conceptual elements that underpin the development of our analytical framework. Section 3 describes the methodology and in Section 4 we analyze three empirical cases from the REE-industry. In Section 5, we offer a discussion and we conclude in Section 6.

\section{Linkages, Boundaries and Risk: Exploring the How and Why of Material Flows}

From a (bio-)physical perspective, the transformation of geogenic into anthropogenic resources involves numerous segments at which processing occurs, including the transformation of mined mineral-containing rocks to beneficiated minerals, to separated elements, components and their assemblies, to final products, their collecting, sorting and reintroducing into material transforming processes. At the minimum, some of these segments represent the baseline for mapping material stocks, processes and flows [48] such as, in its broadest sense, in input-output/material flow analyses (MFA) $[49,50]$ but also in studies of a global scale [24]. However, flows of resources and materials do not just occur. They result from decisions made in multidimensional interaction. This interaction may involve different actors, namely individuals, usually associated with a firm, which activities are tied to the segments in which transformations of resources into materials and reprocessing take place.

Global Value Chain (GVC) analysis explores and analyses the interaction of firms, specifically their transactional characteristics, at particular processing steps or so-called segments. It is a parallel school of thought to Global Production Networks (GPN), which also originates in studies of commodity chains and world systems theory [51]. Questions such as how and why materials flow in a particular way and who is affected advantageously or disadvantageously by these flows are central to GVC analysis. The GVC framework therefore enables us to identify where loopholes exist for material loop closure. In addition to mapping the input-output structure of particular GVCs, a focus is on delineating the geographical location of a segment of transformation. This is a central feature, as it reveals the geography of material flows, as well as market shares in specific segments of the GVC of 
particular countries and their firms. Lepawsky [52] demonstrates the limitations of statistical analysis of Comtrade data for explaining e-waste trade networks, specifically for understanding, "the purposes for which such trade occurs or the end to which the commodity so traded is put (e.g., final disposal, reuse, recycling or recovery)", and emphasizes the importance of empirical studies.

While the mapping of activities provides a macro-perspective of particular GVCs, the scholarly and policy discourses could benefit from connecting this perspective to the meso- and micro-level analyses to understand how different geographical outcomes arise. This is where the conceptual framework of GVC can assist: GVC analysis places emphasis on governance. It is a central conceptual and analytical element of GVC analysis, and, put differently, rests on an identification of forms of coordination and control among firms. Specifically, decisions on material input and output at GVC segments are informed by governance structures and affect manufacturing process and End-of-Life (EoL) product handling, including recycling. Governance structures are key to gaining an understanding of how material loops can be closed.

The GVC framework enables an analysis of how these forms of coordination and control come into place [31,53]. It provides three variables for a given transaction between a buyer and a supplier to examine how a transaction takes effect: (i) the complexity of the transaction; (ii) the ability to codify transactions; and (iii) capabilities in the supply-base (see Figure 1). These GVC variables are allocated a high or low value to derive five governance structures, as depicted in Figure 1. Market and hierarchy structures are at the extreme ends, where price determines a transaction at the former and the acquisition of one firm by another defines the latter. Essentially these structures define the limits of transactions i.e., whether these are effectuated within firm boundaries, among particular firms, or, in principle, accessible for all potentially interested firms in a national or global environment. The latter also gives rise to the regulatory framework, the fourth analytical dimension of the GVC framework. In between these extreme forms of coordination and control are network forms of governance-modular, relational and captive structures-in which the buyer-supplier interaction is seemingly less skewed towards one actor of the transaction [31].

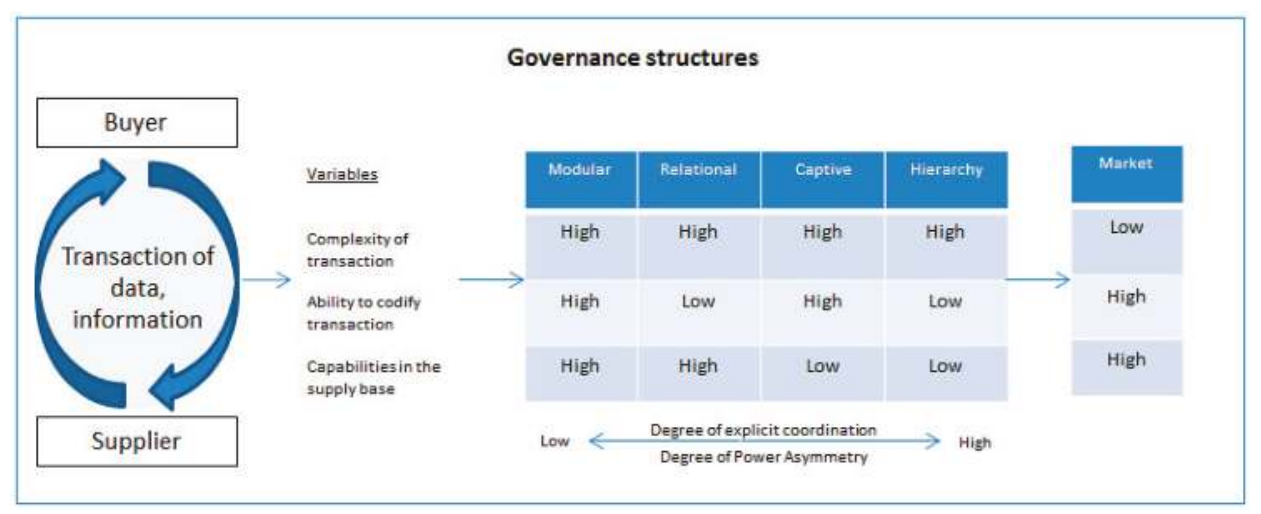

Figure 1. Governance structures in the global value chain (GVC) framework. Source: modified after [31] (p. 87).

Recycling activities have become the subject of scholarly focus as these appear to be underpinned by dynamics different to those known from conventional linear models. Crang et al. [54] challenge the accuracy of the described governance forms for different supply-demand dynamics in recycling activities, i.e., as supply arises independent of, and not in response to demand when products reach their EoL and are reintroduced into material cycles through reuse or recycling. The authors demonstrate the prevalence of brokered forms of governance in recycling networks, the "co-ordination from the middle by brokers", tied to the "heterogeneous materiality" of used goods [54]. Lepawsky and Billah [30] showed that the trade in EoL electronics lacks the formal systems of control that standardize 
the commodity in terms of quality or that adjudicate disputes in cases of unsatisfactory exchanges. They emphasize the significance of "personal attention" by Bangladeshi rubbish electronic importers to their shipments. The prevalence of brokers [54] and the "personal attention" to shipments of waste electronics [30] point to a form of coordination and control with similarities to the relational governance structure. The observations of these authors also imply that some risk-value construction linked to the quality of the materials in a particular transaction is considered by brokers to be worth managing.

The presence of product or process standards can alleviate this risk, as empirically demonstrated and manifested in the market and modular governance structures of the GVC framework. As Humphrey and Schmitz [55] (p. 23) pointed out, "the main reason for specifying process parameters along the chain is risk". As firms engage in non-price competition, these performance risks augment [55]. These performance risks include continuity and consistency of supply, and the conformity of a product to a standard [55]. Standards have the potential to determine the transactional characteristics, particularly in market and modular governance forms of the GVC framework where there is a specific point of transaction, in other words, a clear handover point between the buyer and the supplier. In the networked governance forms, a transaction continues to center on the provision of information as well as price. Gregson et al. [10] emphasize the importance of quality outputs from recycling processes and the challenge in meeting quality standards for recyclates. In a study of the recycling of steel from demolished buildings, Santos and Lane [29] suggest that the lack of standards for EoL construction materials, which would "express" their material quality to suppliers and clients, is a significant barrier to their reintroduction into material processing. Their point echoes that of Crang et al. [54] who further emphasize that standards and the related classification of goods and materials as hazardous waste, affect the movement of recycled goods by mandating particular forms of processing. Santos and Lane [29] (p. 46) conclude that the building construction regime is characterized by "a particular set of practices" which excludes reused steel components. Transactional characteristics, such as those discussed on certain industries, in which risk and value considerations are constructed, may shed light on particular practices and help to explain the lack of material loop closure.

In this paper, we therefore combine the governance structures arising in transactions with the relational theory of risk [32] and apply this to our REE case studies. The aim of this marriage of two theoretical frameworks into one is to support the specific objective of this paper, namely to inform on the pre-price forming dynamics in transactions between a buyer and a supplier of material. The transaction is key to both the governance structures as well as to the risk construction, where the transaction is that of information and data.

The relational theory of risk builds on the work of Hilgarnter [56] who argued for a shift in focus from asking "What is risk?" to "How do people understand something as a risk?", and on similar arguments developed other scholars of risk [57-59]. This constructivist perspective of risk, which focuses on how risk is constructed by the various actors, takes risk assessment as an inherently normative evaluation [32,57]. Importantly, the description of a risk object-which may take the form of a physical, cultural or social artifact-necessarily involves ascribing it "some value" [32] (p. 177). Corvellec [60] also argues that value is derived from organizational practice which coincides with the theoretical underpinnings of the GVC framework.

In the risk taxonomy [61] (Figure 2), we situate the relational theory of risk [32] predominantly in the upper right corner of the systems and cultural theory. Systems theory, most prominently argued by Luhmann [62], works with risk as a social construct, alongside the importance of system boundaries and the focus on the "communication between systems" [61]. Cultural theory also works with risk as a social construct and places analytical emphasis on cultural patterns, and therefore extends beyond the focus of this paper. The relational theory of risk [32] also seems to point to a link with the social amplification of risk, namely that of causal relations and the integration of different perspectives of risk, allowing a systematic analysis of empirical findings. 


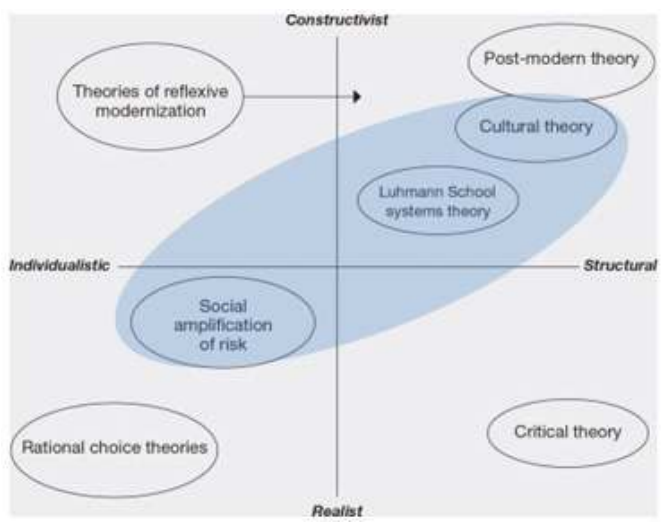

Figure 2. Review of sociological approaches to risk. Source: [61] (p. 40); oval highlight added to situate the relational theory of risk [32].

The analytical focus of the relational theory of risk is the communication in which risk is semantically created [32] (p. 186). This is also emphasized by Howes [63] who noted that "risks are partially socially constructed by discourse". It places the actor center-stage to explain the dynamic of how risk is constructed by drawing on a "tripartite deconstruction of risk elements" namely the semantic networks that contain "objects at risk", "risk objects" and "relationships of risk", and their evolvement over time and in space [32]. These three elements are further explored hereafter.

The risk objects are characterized by a fluid, dangerous identity. Risk is introduced into the social space when an object is designated as risky from which it swiftly becomes independent while remaining tied to social practices and representations [32]. As societies evolve, so does understanding and formulation of values as well as of dangers with the result that the definition of risk objects also changes.

The objects at risk are endowed with a value at stake. Here the reference to value bypasses moral judgment of good or bad, moving to "something that is held to be of worth" and might be nature, life, principles or a state of affairs. This is in stark contrast to presenting value solely as a monetary unit. Boholm and Corvellec [32] (p. 180) pinpoint that "objects at risk are constituted around traits such as value, loss, vulnerability, and need for protection". Thus, designating an object at risk is equivalent to assigning value. Allwood et al. [1] acknowledge the involvement of a wider range of values in their work on material efficiency. Bocken et al. [64] also consider the value proposition between and amongst different stakeholders, including network actors (e.g., firms, suppliers, etc.), customers, society and the environment. This is useful in demonstrating how values can be allocated or traced amongst different stakeholders.

At times, agreement in society is reached about what is valued, and what objects are perceived to be at risk, and how, taking a normative turn, these should be protected. It is here where government, including with its legislative arm, plays a significant role [32] (p. 180). Indeed, there are many established environmental setting targets for businesses to deal with the environmental impacts of their products; for example, eco-design policies (see e.g., [65]), top-runner programs (see e.g., [66]) and extended producer responsibility policies (see [67]). This is reiterated by Porter and Kramer [68] who recommend that governments learn how to regulate in ways that enable, what they define as "shared value". Notably, Porter and Kramer [68], while presenting some interesting criticism of neoclassical theory, specifically that of Milton Friedman, continue to work with a growth paradigm in which economic and social progress, are separate phenomena, a clear friction with the theoretical underpinning of this paper where these are inseparable. In this paper, individuals are viewed as engaging in transactions, independent of whether they represent a firm, a customer, a government 
or are associated with another organizational form. When Gereffi and Korzeniewicz [69] first conceptualized commodity chain analysis, they were partially inspired by M.E. Porter [70], specifically his "value chain" as opposed to "value added" notion which allowed an exploration of linkages among economic activities. Gereffi and Korzeniewicz [69] merged these elements with some from sociology to add explanatory potential to the framework for the different socio-economic outcomes of what is now known as global value chains in the field of economic geography.) They specifically point to regulatory measures that work with attainable, yet ambitious targets rather than prescribing a particular mode of reaching these. However, critics of Porter and Kramer point out that reaching consensus in practice might be more difficult, not least because of the complexity of value chains and how systemic problems are perceived by organizations [71].

Both popular and scholarly narratives can galvanize societal agreement on the object of value and at risk, as well as the approaches towards protection. This is evident in the shifting narratives that frame materials as either useful resources or waste [72]. Another example is the classification of resources into either primary or secondary materials versus a singular category that embraces both. Moreau et al. [23] refer to geogenic and anthropogenic resources while Mueller et al. [44] do not emphasize origins of resources but turn to the issue of "accessibility" of resources. Similarly, the term "stocks" in industrial ecology bridges the natural and the social when, for example, stocks of metals are examined. Here, the term "urban mines" enables a comparison of anthropogenic stocks to geological occurrences. Interestingly, it is here where the different ontologies of the social- and material-/natural sciences come to the forefront. These examples pinpoint scholarly efforts to create narratives to bridge rather distinct worldviews between schools of thought, i.e., whether a particular geogenic occurrence exists without human interference, and is therefore "natural", or whether it exists solely because of human action, as we "socially construct" it by conceptualizing, describing, and classifying.

Striving towards a co-existence of conceptual understandings seems to offer most positive outcomes, especially as any discourse will inevitably transport particular values of any school of thought participating in it. In other words, when interdisciplinary discourses turn to depicting value including in distorted conceptualizations of the GVC, more often than not, the default understanding will be that value is reflected as the price of a material (and other value, i.e., environment remains vaguely associated).

Relationships of risk are observer established, see Figure 3: When an observer constructs "a link" between a risk object and an object at risk, whereby the former is understood as potentially threatening the value of the latter, then a relationship of risk is present [32]. Critical to the conceptualization of the relationship of risk in the relational theory of risk is understanding that the relationship is a construct. It needs to be made and crafted, and this process occurs by "semantic association between objects" [73].

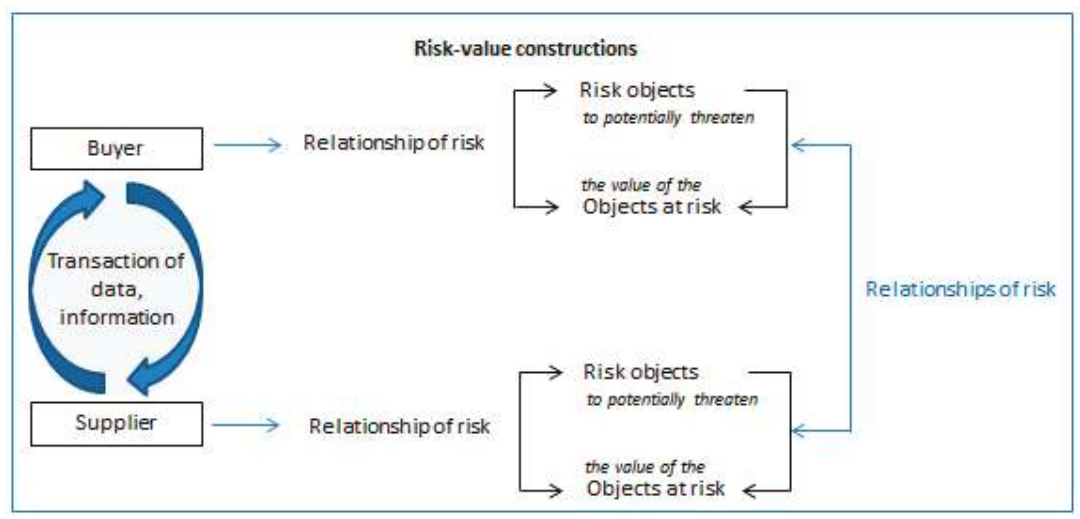

Figure 3. Risk-value constructions. Source: adapted from [32]. 
Examples of these constructions are models, laboratory tests, narratives or probabilities [32]. The parameters of risk relationships are contingency, causality and action and decisions to act. Exploring these parameters in more depth leads firstly to the "What if?" question which is central to the relationship of risk, and contingent in as far as risk describes a potentiality of occurrence rather than a certainty. Secondly, it is evident that the relationship of risk needs to establish the causality between the risk object and object at risk. Thirdly, action and decisions to act are key to the relationship of risk. As Boholm and Corvellec [32] (p. 181) put it, "Risk is conditioned by a modern will to know that remains welded to a will to decide and act under conditions of uncertainty". It is the assembly and reciprocity in the form of a causal-contingent relationship that allows risk to be established. The continuous reframing and redefinition shapes relationships of risk, as well as the coexistence of various relationships of risk that reflect diverse views, cultures and knowledges embedded in society. Thus, as Boholm and Corvellec [32] (p. 182) summarize "What is a risk object for some can be an object at risk for others".

\section{Methodology and Data}

Our analytical framework is built from the conceptual elements of governance derived from the GVC framework, and from the risk-value constructions of the relational theory of risk $[31,32]$. We conceptualize both of these elements as arising in transactions of data and information between interacting individuals or entities, here simplified as the buyer and the supplier. The transaction occurs prior to a (contractual or informal) agreement to exchange a material, product or service, see Figure 4a,b, with the former (Figure 4a) illustrating the analytical and empirical focus of this paper. Thus, rather than a transaction based on an established price, the focus in this paper is on the transaction of data and information that occur prior to and shape a price, in light of GVC governance and risk and value constructions.

(a)

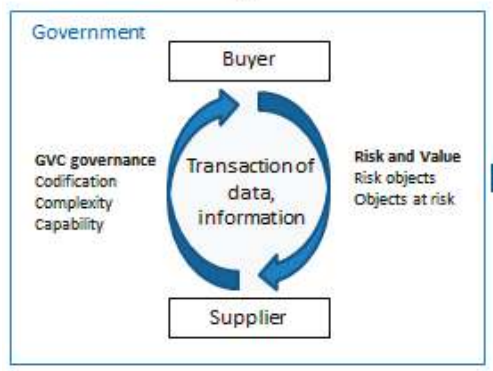

(b)

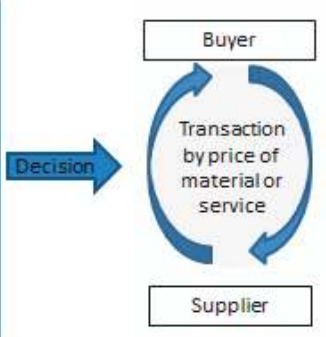

Figure 4. Analytical framework based on stylized linkages of transactions: (a) of data and information preceding price formation; and (b) of price of a material or service. Source: adapted from conceptual elements of [31,32]. Note: Figure 4a shows the GVC variables upon which governance structures are determined. The construction of risk through the relational theory of risk is included as a significant dimension of the transaction (and based on Figure 3). From the exchange of data and information under risk and GVC governance in Figure 4a, a decision is made which, presuming successful risk communication, results in the construction of a price (Figure $4 \mathrm{~b}$ ), upon which an exchange of material takes place.

This transaction simplifies one interaction at a particular segment in which a processing activity occurs that requires an input and an output. As the buyer and supplier exchange data, information is built up on the extent to which the material or service desired can be codified for a "handover", this process is represented in the GVC governance variable "codification of transaction". The exchange of data also provides insights into the "complexity of the transaction", the second GVC governance variable. As the parties exchange data, information builds up that enables them to gather an overview of the respective "capabilities" of the transactional partner, the third GVC governance variable. 
The exchange of data between the partners is suggestive of their perception of its value, and thus, in line with the relational theory of risk, they are simultaneously constructing relationships of risk, by identifying risk objects and objects at risk. These constructed risk relationships at the buyer and supplier interaction might con- or diverge from each other. In conjunction with governance structures, they determine whether material loops, such as of REE, are closed in practice. When a positive decision is made, a risk relationship was constructed by either partner that matches that of the other providing a foundation of a stable risk relationship that allows a transaction of a material or service to "materialize", as shown in Figure 4b. This conceptualization speaks to that of Lepawsky and Billah [30] (p. 126) who convincingly argue for recognizing, "value as in-the-making rather than an intrinsic property of things".

Our methodology follows the analytical framework elaborated above and is inspired by the relational theory of risk which emphasizes the importance of the "lived-in world" as opposed to the "intangible world of concepts" that define risk [32]. Thus, the relational theory of risk focuses on examples of "communities of practice" [74] or of "organizational contexts" to "concretize the study of risk objects, objects at risk, and relationships of risk" [75,76]. In so doing, it underlines the importance of empirical case studies for creating an understanding of risk.

On three empirical cases we demonstrate how the construction of risk affected the implementation of business plan conceptualizations and lab-scale tests of new technologies and why risk in REE-loops needs to be targeted with governmental response for transparent material characterization. We delineate the governance forms that appear to determine the particular transaction at the segments which are subject to our observations of construction of risk. We then describe the situated view of each concerned actor on the "risk object" and "object at risk" to explore the nature of the actors' observed "relationship of risk", i.e., whether it is considered "stable" or "unstable" and with which effect for loop closure. This narrative is guided by our analytical framework.

Our data consist of empirical material, specifically transcripts of interviews conducted between February and June 2017, in addition to empirical evidence gathered since 2012, and literature reviews that include websites of start-up firms in the REE industry and of EC-funded REE-focused research projects on which industry developments are discussed. Some of the semi-informal interviews with industry representatives arose from simple requests for information and clarification in the course of the preparation of a research proposal that aimed at closing REE-loops in practice. This is an important aspect of the data collection, as this approach enabled data collection that, retrospectively, proved highly useful in shedding light on the daily practices of businesses and, importantly, also on the narratives defining their daily practices, in addition to the organizational context of a particular firm.

The analytical variables of the global value chain (GVC) framework-complexity of a transaction, ability to codify a transaction, capability of the supplier-support our assessment of the transactional characteristics, i.e., the governance structures between a buyer and supplier at the segments of our empirical cases. We assess whether a given transaction is characterized by a "low" or "high" complexity, whether the information transferred is easily codifiable or not, i.e., when product or process standards are present, or procedures established, and whether low or high capabilities to execute the transactional requirements are observed at the supplier (and buyer).

We then draw on the three elements—risk object, object at risk, and relationships of risk- that constitute the relational theory of risk, as described earlier, to create an understanding for policy-makers and scholars alike of the risk communication at selected REE-value chain segments, as well as of governance structures, and how these affect the possibility of closing REE loops. To substantiate this approach with pragmatic entry points for action, we follow the proposal of Boholm and Corvellec [32] (p. 187), that the key to successful risk communication is establishing "a common understanding of what constitutes a threat, a value, a contingency, and a causal relationship". This methodological approach provides us with the means to depict the sequence of narratives that impact significantly on, for example, the translation of proven technologies for REE recycling, of which many have arisen over the last few years at sub-commercial scale, to testing these on a commercial-scale for market-readiness. 


\section{Findings}

China, as dominant REE-supplier, was identified by both government and industrial actors as the risk object in the aftermath of REE-price peaks of 2011, and the continuous accessibility of stable-priced separated REE products as the object at risk. A stable relationship of risk was constructed between governments in the EU and in the US, and a common object of risk agreed upon that was evident in narratives of "supply risk". In response, many publicly funded projects have developed technologies for REE-separation and recycling on a lab-scale (see i.e., EC-funded FP7 or H2020 projects such as [77-84]) and the potential for recycling was discussed (e.g., [37,85-89]). Surprisingly little progress occurred from lab-scale tests of the technologies to commercial implementation.

With continuity of China as dominant REE-producer and user, supply risk (notably from registered, documented sources of production) of the REE remains unchanged. However, the REE prices have changed: Since the 2011 REE price peaks they have returned to or even dropped below pre-peak levels [78] (p. 135). It is proposed that prices are the reason for struggles of REE firms in Europe [36]. Is it possible that price developments alone are the single reason for why the publicly funded and developed technologies are not transiting into commercial life and are not pursued to close loops of REE? This explanation appeared to be too simplistic given that risk-value constructions occur prior to price formation. As the purpose of initiating many of the projects was to mitigate risk, and this risk arguably remains, closer examination is warranted.

The case studies of specific GVCs of REE reveal insights into numerous complexities: The REE value chain is global and multi-layered with numerous actors interacting at each segment, inevitably bringing a myriad of data and information together in any given transaction prior to reaching agreement for the actual exchange of a material or service, or both, based on price and, in some cases, information accompanying this exchange. Figure 5 delineates a stylized schema of the global REE value chain segments in which the three empirical cases to be discussed in the following sections are highlighted.

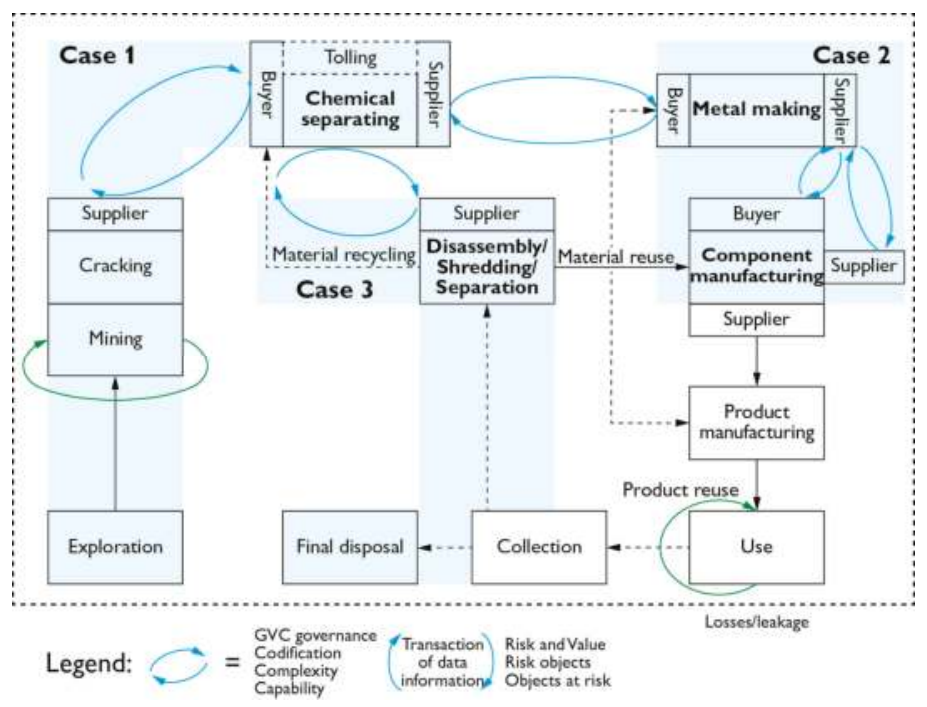

Figure 5. Stylized schematic of the empirical cases addressed of the GVC of REE. Note: This figure illustrates, clock-wise starting left, the GVC segments (in blue-edged squares) from exploration of underground REE-mineral occurrences through various processing steps of REE-bearing minerals to REE-metals, components, final products with REE-components, up to the segments attached to closing material loops. The segments that are discussed in our case studies are highlighted in blue. 


\subsection{Case 1: Construction of Risk Relationships for a REE-Tolling Station}

Chemical separation is a key segment in the global REE value chain, both in processing of the rocks and of EoL material for closing a loop. Its outputs are individual separated REE, such as oxides of praseodymium, neodymium, dysprosium or europium. Commercialized technological processes for chemical separation are tied to high capital- and operating expenditures (CAPEX, OPEX) and require cross-cutting knowledge of mineralogy, geology, chemistry and metallurgy. The purchase of both batteries and annex equipment for the liquid-liquid extraction (i.e., solvent extraction (SX)), and induced equipment (e.g., for specific effluent treatment) constitute major CAPEX [90]. OPEX stems from the use of energy and solvents (including losses), handling and storage of radioactive material, effluent treatment and taxes for discharge streams.

From 2012 to early 2016, when REE-industry participants anticipated another imminent rise in REE prices, the discussions on mitigating a potential REE-supply risk centered on the idea of establishing particular organizational structure, referred to as a tolling station. This station had the aim of minimizing the CAPEX a single firm would need investing for a plant infrastructure. It was conceptualized as a centralized facility operated by a consortium of mining companies and end-users, see [91] (p. 59). The tolling station would provide chemical separation services by processing a mixed REE solution (salts/oxides/chlorides/nitrates), the output of a flotation process, from numerous suppliers of different REE-containing ore into individual REE, complying with quality requirements of potential buyers.

In addition to the government regulator, four actors come together with interests in the processing segment of chemical separation (see Figure 5 for the processing segments and notes on the GVC of REE): the exploration firm (which seeks to sell its developed deposit to a mining firm), the mining firm (that delivers the input of REE-minerals and conducts in many cases also the cracking of the REE-mineral into a mixed REE solution), the chemical separator (which separates the REE-minerals into individual REE products), and the customer (often a metal maker, which uses the individual separated REE product).

In the transaction between the mining firm selling the REE-containing rock and the chemical separator buying it the ability to codify the transaction is high as it is limited to the knowledge gained from assaying the mineral cores of the drilling programs along with other information from the bankable feasibility study, both of which can easily be exchanged. There is a degree of uncertainty as to the exact composition of each mineral concentrate. However, the complexity of this transaction is low as no additional information needs to accompany the handover of the mineral concentrate. With a view to the capabilities at the supplier end, they are high when it comes to producing a mineral concentrate from an ore that has already been commercially processed in the past. These characteristics of the transaction suggest market governance determined by price, summarized in Table 1 .

However, if the REE-bearing ore has not yet been commercially processed, as would be the case for a tolling station that buys from several REE-bearing deposits that have not been mined previously, the characteristics of the transaction change to one in which the complexity of the transaction is high, as coordination needs arise between the various suppliers of the ore to the operator of the central tolling station. The ability to codify the transaction would be low, as information in addition to price must be exchanged. The capability of the supplier would also be low as it is no longer the individual capability of one supplier but the aggregated capability of the suppliers that must be accounted for. This suggests a hierarchy governance form in which the actual integration of chemical separation with the mining firms is most feasible. This decision-making process for or against entering into such a transaction on either side (supplying mining firm and buying chemical processor and operator of a potential tolling station) gives rise to the construction of risk-value relationships, described hereafter. 
Table 1. Case study 1: Transactional characteristics between the mining and chemical separation segments.

\begin{tabular}{ccccc}
\hline Transactional Partners & $\begin{array}{c}\text { Ability to Codify } \\
\text { the Transaction }\end{array}$ & $\begin{array}{c}\text { Complexity of the } \\
\text { Transaction }\end{array}$ & $\begin{array}{c}\text { Capability of the } \\
\text { Supplier }\end{array}$ & $\begin{array}{c}\text { Governance } \\
\text { Form }\end{array}$ \\
\hline $\begin{array}{c}\text { Transaction between the mining firm } \\
\text { and the chemical separator for a } \\
\text { commercially processed REE-ore }\end{array}$ & High & Low & High & Market \\
\hline $\begin{array}{l}\text { Transaction between mining firms } \\
\text { and the tolling station operator for } \\
\text { lab-tested REE-ore }\end{array}$ & Low & High & Low & Hierarchy \\
\hline
\end{tabular}

As exploration firms eagerly worked towards bankable feasibility studies for their respective REE-bearing mineral deposits, their focus was on attracting customers to demonstrate the feasibility of their business plan to mining firms. The latter would then be willing to purchase their developed mineral deposit, as mining is rarely an activity exploration firms pursue, see [92]. Thus, their business plan development centered on establishing integrated chains from exploration and mining to chemical separation (see [33,93]), when they realized that customers had an interest in separated, individual REE products. REE-mineral mining was therefore to be combined with further processing of the minerals.

The exploration firm with rights to explore deposits, e.g., in Australia, Canada and Greenland, perceived the inexistence of independent chemical separation facilities outside of China as a risk object, and the resulting dependence on Chinese suppliers for individual REE oxides, the output of chemical separation plants, as the object at risk ([91], p. 59). The mining firm agreed in principle with this conceptualization of elements in the construction of a risk relationship, while acknowledging that its business portfolio and expertise commonly remains limited to mining and physically beneficiating the minerals. Therefore, the mining firm relies on the chemical separator and customer (metal maker) to confirm the proposed risk relationship of the exploration firm.

For the chemical separator in the EU, the risk object is access to REE-ores under tight regulation in China, and the object at risk is its business activity of separating REE-minerals into individual REE products. The action that was taken in response to this risk relationship was the establishment of plants in China, where major REE-demand originates. This took the form of, e.g., joint ventures with local firms (see [33]).

The tolling station concept would provide input from different REE-mineral deposits, and here, the chemical separator would see the risk object as the properties of the minerals fed into the separation process, with the object at risk being the cost structure of its operation, and thus, of its final product, the individual REE elements. This argument rests on the significance of the correct choice of the solvent for a cost-effective separation, followed by the selected technology and the number and fixed sequence of REE to be individually separated.

The risk relationship portrayed by the exploration firm is unlikely to be confirmed by the chemical separator who has already mitigated against the risk relationship with plants in China which also represents a major growth market. Further, the separator appears to perceive the risk relationship for the tolling station as unstable, framing the risk relationship differently to the exploration firm, in the context of REE-industry dynamics in which China continues to play a dominant role and where undocumented production accounts significantly distorts of REE market prices and affects the willingness to invest.

The customer of the individual REE products in the EU, i.e., a metal producer, perceives the risk object as the limited supply channels outside China from which individual REE products can be sourced and the object at risk as its continuous supply of high-quality REE products at stable prices.

In response to this defined risk relationship, the user has taken steps to relocate manufacturing activities to China, in addition to engaging in in-process recycling of REE-materials with its customer, i.e., a magnet manufacturer (see next empirical case). Thus, while the customer shares a common risk object and object at risk with the junior exploration firm, the customer appears to have taken measures to address this risk relationship. 
With regards to the proposed tolling station, the customer sees the risk object as the adaptation of the separation process required to accommodate REE-mineral types, and the object at risk as its standards of high purity for the individual REE products. Lab scale tests of the adaptation of the chemical separation process, or new technologies tested at lab scale are unlikely to provide sufficient assurance that the risk is sufficiently addressed.

While the definition of risk object and object at risk by the exploration firm would have in principle approval from the various actors, the differing conceptualizations of the elements of risk by the same actors and their mitigating actions, a common risk object cannot be defined. Thus, the communication of risk is unsuccessful. This may explain why the push for a tolling station has stalled.

\subsection{Case 2: Pre-Consumer REE-Magnet Recycling}

At the magnet manufacturing segment three actors come together: The magnet manufacturer who purchases a REE-magnet alloy, the metal and alloy producer, and the customer who purchases the REE-magnets. Between the former two the governance form that arises is modular in that the specifications for the metal required are easily codified, including by standards that incorporate material performance qualities. Nonetheless, the complexity of the transaction is high since many performance criteria need to be met. In the context of a very capable supplier, the metal producer, the complexity of the transaction can be handled without problems, as the metal producer possesses the knowledge that enables the codified transaction $[94,95]$.

In contrast, when it comes to closing material loops, the ability to codify the transaction of scrap magnet metal, a byproduct of shaping the magnets into the form desired by the customer, is low. The complexity of the transaction between the magnet manufacturer and the metal maker is high, as the highest possible level of detailed information must be exchanged between the two actors in the transaction. This includes for instance confirmation that only sintered magnet material is being returned, as bonded magnet material includes epoxy that poses a contamination risk for the material streams of the metal producer. Further information on the type of magnet alloy, i.e., the composition of the alloy including REE content, is useful in the exchange. The capability of the supplier is high in as far as the magnet manufacturer is a competent partner in the transaction who understands how the magnet alloy should be handled and what type of information facilitates a successful transaction that will deliver new REE-containing metal alloys in return. These characteristics of the transaction suggest a relational governance form in which coordination between the transactional partners is required although they are still relatively independent from each other. However, there has been a clear change in the type of governance structure from the first, conventional linear transaction under modular governance, to that of closing the loop with pre-consumer recycling and relational governance due to increasing coordination needs. The characteristics are summarized in Table 2.

Table 2. Case study 2: Transactional characteristics between the metal making and magnet manufacturing segments.

\begin{tabular}{cccccc}
\hline Transactional Partners & $\begin{array}{c}\text { Ability to Codify } \\
\text { the Transaction }\end{array}$ & $\begin{array}{c}\text { Complexity of the } \\
\text { Transaction }\end{array}$ & $\begin{array}{c}\text { Capability of the } \\
\text { Supplier }\end{array}$ & $\begin{array}{c}\text { Governance } \\
\text { Form }\end{array}$ \\
\hline $\begin{array}{c}\text { Transaction between the metal maker } \\
\text { and the magnet manufacturer }\end{array}$ & High & High & High & Modular \\
\hline $\begin{array}{c}\text { Transaction between the magnet } \\
\text { manufacturer and the metal maker }\end{array}$ & Low & High & High & Relational \\
\hline
\end{tabular}

For the magnet manufacturer, the risk object is the availability of a high-purity REE-metal alloy and the object at risk is the accessibility and stability of the price of this alloy over time. For the supplier of the metal-alloy, the risk object is as described in the previous section, the limited supply channels outside China from which individual REE products can be sourced, and the object at risk is its continuous supply of high-quality REE products at stable prices to the buyer. 
To mitigate the established and agreed risk relationship by the magnet manufacturer and alloy producer, the latter communicates the risk to the magnet manufacturer who loses material in the manufacturing process from out-of-spec magnets or from shaping the magnet. The REE-magnet manufacturer provides REE-material for reprocessing to the REE metal producer. This REE-material is solid sintered material and re-melts well and cleanly. The REE-metal producer reprocesses it in batches of material belonging to a particular REE-magnet manufacturer and, while it may be of different compositions, a first-stage melt is conducted to understand the composition (and adjust it accordingly, if needed) and then blend it with $70 \%$ of virgin material to produce a new metal alloy for the magnet manufacturer.

The REE-magnet purchasing customer frames its risk object as the REE-alloy used in, and the manufacturing process itself, of the magnet, and the object at risk as the accessibility, price and performance according to magnetic standards of the magnet purchased.

\subsection{Case 3: REE Recycling of End-of-Life Lamps}

While REE are found in many End-of-Life (EoL) electronics, commercial recycling of REE from this source has so far only been technically and economically feasible for a select number of product groups, including fluorescent lamps. However, before EoL lamps can be processed for recovery of REE, lamps must first be collected. Collecting and environmentally sound recycling of lamps is a net cost for recyclers, making it unlikely that this will happen beyond small-scale voluntary initiatives without legislation [46]. Extended producer responsibility (EPR) schemes in EU countries is mandated by Waste Electrical and Electronic Equipment (WEEE) legislation, which requires collection and recycling infrastructure for EoL lamps (fluorescent and LEDs) and specifies at least $80 \%$ of collected mercury lamps must be recycled and mercury removed. EPR schemes involve multiple actors including national authorities, local municipalities, producers, retailers, local waste management companies, specialized recyclers, and consumers who engage in multiple transactions enabling the physical, financial, and informational flows that underpin EPR schemes (see [47] for an overview of actors and transactions in EPR systems for lamps in the Nordic countries).

While collection of EoL products is a necessary precondition to recycling of REE from these products, the focus in this case is on the decision to recycle REE from lamps, not on the collection decisions. The main actors influential in this decision are lamp recyclers who process the initial EoL lamp waste, chemical separators of REE, and producers of products using REE, who are the customers buying the recycled REE. Due to the net costs involved in lamp recycling, recyclers operate in mandatory and voluntary schemes with a focus on sound environmental management of the mercury in the lamps and in keeping recycling costs low. Mandatory WEEE legislation in the EU (as well as voluntary standards for mercury containing lamp recycling) require special processes for removal of the mercury, most of which is generally contained in the phosphor powder fraction along with the majority of REE. Recycling processes also aim to recover glass, metal, and plastic fractions though it can be challenging to find markets for recycled fractions (other than metal) [46].

The treatment of EoL phosphors for recovery of REE typically involves two main steps (as well as several specific technical process steps): (1) removal of mercury, glass and other impurities from the powder, yielding a REE-rich mixture; and (2) separation of REE mixture into individual REO. Both steps can be performed by the same firm (e.g., Solvay-Rhodia operated a commercial process until the end of 2017, with Step 1 in their Saint-Fons plant and then sent the mixture to their La Rochelle plant) or by two different firms (e.g., there are several pilot projects now performing Step 1 and looking for customers for the REE mixture as is or Step 2 chemical separators). While there can be markets for REE mixtures from Step 1, these have lower market value than individual REOs, however chemical separators able to perform individual REE separation are limited and there are no longer options for heavy REE found in lighting phosphors available in the EU with the closing of the Solvay-Rhodia operation [96]. 
The recycled phosphor powder fraction comprises $2-3 \%$ of the volume by weight of the total recovered material from the lamp recycling process. If disposing of the phosphor powders, lamp recyclers face costs depending on the mercury content of the phosphor powder and the specific hazardous waste requirements for landfilling or permanent storage (e.g., in salt mines in Germany). These costs are driven by disposal costs in the jurisdiction and can be easily quantified and anticipated, and can be characterized as a market governance form. By contrast, the processing the phosphor powder depends on changing this business practice, finding a chemical separator, and negotiating prices with Step 1 chemical processors (also different lamp recycling processes and input waste yield different phosphor powder mixes, some of which may not be compatible with processes for REE recovery [97]). The lamp phosphor waste represents a new source of REE with its own characteristics requiring refining processes (Step 1) to be specifically designed. At the same time, the supply is dependent on collection of the EoL lamps and is also influenced by product technology change. Thus, there are several challenges to codifying, such as uncertainties about the capabilities of the supplier and high complexity, indicative of a hierarchical governance form.

The ability of chemical processors to operate, in turn, depends on customers and market values for the REE mixtures and REOs, both of which have been dynamic and unpredictable in recent years. While large established chemical separators have the capability to perform Steps 1 and 2 of the chemical separation for lamp phosphors, some smaller operators only perform Step 1 and attempt to sell the refined REE mixture or carbonates to end customers or Step 2 refiners. Even so, the transaction can be codified and the supplier is capable, though the transaction is still complex, indicative of a modular governance form, see Table 3 .

Table 3. Case study 3: Transactional characteristics between the lamp recycling and the chemical separation, and the landfill/permanent storage segments.

\begin{tabular}{ccccc}
\hline Transactional Partners & $\begin{array}{c}\text { Ability to Codify } \\
\text { the Transaction }\end{array}$ & $\begin{array}{c}\text { Complexity of the } \\
\text { Transaction }\end{array}$ & $\begin{array}{c}\text { Capability of the } \\
\text { Supplier }\end{array}$ & $\begin{array}{c}\text { Governance } \\
\text { Form }\end{array}$ \\
\hline $\begin{array}{c}\text { Transaction between the recycler and } \\
\text { landfill/permanent storage operators } \\
\text { for EoL lamp phosphors }\end{array}$ & High & Low & Migh & Low \\
\hline $\begin{array}{c}\text { Transaction between the recycler } \\
\text { and the chemical separator for EoL } \\
\text { lamp phosphors }\end{array}$ & Low & High & Hierarchy \\
\hline $\begin{array}{c}\text { Transaction between the chemical } \\
\text { separator and customers }\end{array}$ & Med-High & High & Med-High & Modular \\
\hline
\end{tabular}

A key actor in the decision of whether to recover REE from phosphor powders is the lamp recycler who first manages the treatment of the waste after collection. However, lamp recyclers are contracted by producers who are fulfilling EPR obligations, municipalities, or actors behind voluntary initiatives. The value for these actors is to soundly manage the waste, particularly the mercury which is often pursuant to mandatory obligations and treatment requirements. Recycling of fluorescent lamps is not economically viable based on material value of the recycled materials alone, so the environmental and health benefits of treating the mercury drive voluntary initiatives as well as mandatory EPR legislation [40]. The risk object for the government in recycling lamps is the mercury in energy efficient lamps, while the public health and the environment comprise the main object at risk. Lamp products utilize mercury in the design in order to dramatically increase the energy efficiency of the product, in comparison to incandescent lamps, and result in lower overall emissions of mercury when considering the entire lifecycle of the product (due to decreased energy needed, which in turn have associated mercury emissions if there is any coal in the mix of energy used to produce or use the product). To manage the risk of mercury, the WEEE directive specifies that mercury must be removed in the recycling process, and, since 2011, there has been an export ban and disposal obligation for mercury. 
Though closing material loops is an explicitly stated aim of EPR legislation in the EU, the legislation does not require the recovery or use of the REE material and thus the decision to send material for further recycling depends on the motivation of the recycler to send the phosphor powder on to a chemical separator. However, to keep the cost of treatment low (to retain contracts for the recycling), the recycler is also incentivized to do this at the least cost while still complying with the legislation as another risk object for the recycler is the cost of treatment in order to preserve competitiveness. The recycler compares the cost of disposing of the waste lamp phosphor powder with sending the phosphor powder to a chemical separator. Some recyclers also investigated refining the phosphors themselves but had little capacity and found there was no business case for small batches, thus necessitating a transaction with a larger chemical separator. The recycler's decision is also final for the fate of the REE content as a common method of disposal of mercury waste, including waste phosphors, is as mercury sulfide in permanent storage, e.g., in salt mines in Germany or in controlled landfills, depending on mercury content and legislation. Once waste phosphors are stored in this manner their potential as a source of REE is lost [98].

While some Producer Responsibility Organizations (PROs) who contract the recyclers also indicated that additional value around closing material loops could add to the recycler's competitiveness, not all PROs interviewed identified this value or expectation in their recyclers. Thus the decision for recyclers to recycle or dispose of waste lamp phosphors can be best framed as dependent on the cost of disposal in controlled landfill or permanent hazardous waste storage (depending on the mercury content of the powder and specific rules in the jurisdiction) compared to the cost of sending this powder to a chemical separation process.

Transactions between lamp recyclers and chemical separators capable of further treating lamp waste phosphors are in turn dependent on the salability of REE recovered from the chemical separation processes (i.e., the object of risk). The risk object is the unpredictable REE market, which in the case of lamp phosphors, reflects not only the uncertainties about supply in the context of price fluctuations in response to the dominant production share of China, its control measures and a significant undocumented/illegal market, but also large uncertainties about demand for rare earths as the lighting market shifts from fluorescent to LED lighting technology. The effect of this technology shift is twofold: (1) it decreases the future supply of REE available for recycling from EoL lamp products as LEDs have substantially smaller amounts of REE; and (2) it decreases demand for some phosphor REE, such as Europium (Eu), due to the fact that phosphors currently dominate the demand for this type of REE. In essence, the loop itself is shrinking unless other sectors increase the demand for the REE used in lamp phosphors.

While this could be viewed positively in that recycled Eu could then more easily satisfy the more limited demand of Eu for lighting producers [38], this is further complicated by the fact that Eu mining is also driven by demand for other rare earths found in the same deposits (i.e., as a by-product, reflecting the balance problem described by [35]. As industry faces supply risks, recycling represents one mitigation strategy, but also represents complex transactions between multiple actors and can represent an increased cost. Thus, the value of recycling REE is compared to the value of primary mining and substitution, as these are other strategies for industry to manage such risks. In addition, more focus is needed on the losses of other elements in a REE recycling process [38].

However, mitigation of the described risks through recycling from anthropogenic sources can also provide environmental benefits through avoiding primary mining [99-104]. It was clear from Solvay-Rhodia's communication of its commercial lamp phosphor REE recycling process that the value of recycling REE from phosphors in the EU was beyond pure economic considerations. A respondent from Solvay was quoted characterizing the value for the company for its sustainability and corporate social responsibility agenda, stating that "This project is driven by our sustainable development approach" [105]. Validation of the process entailed a $€ 2$ million investment in a two-year project during 2012-2014 (after investment in development of the process itself), half of this coming from EU Life+ funding (a financial instrument supporting environmental projects). 
The assistance from the EU in terms of Life+ funding again reflects the perception that Chinese dominance of the REE market was perceived as a risk, not only by industry actors such as Solvay-Rhodia, but also by the government actors at the EU level. The recycling of REE in the EU was perceived as socioeconomic value including by enabling a domestic/EU source of REE, 30-40 direct new jobs in the EU, and capacity building in urban mining in the EU [106]. The project report further declared that recycling REE from lamp phosphors would "increase the independence of Europe as regards to REE. It will also help conserve natural resources and reduce the use of environmentally damaging processes in their transformation. This will ensure Europe has access to a sustainable provision of these elements without the risk of shortage that could have dramatic social and economic effects." (p. 11).

However, the closure of the Solvay-Rhodia process, which cited poor economics due to decreased REE prices and decreased demand for the REE in the lighting market [107], and the continued struggle of pilot technology-ready recycling processes to find markets for their products reflects that the risks and values of REE recycling from waste lamp phosphors are perceived differently by industry in comparison to governments. It is clear in this case that industrial actors, while they may be aware of the environmental and societal values that recycling could bring (as evidenced by the framing of the process by Solvay-Rhodia), in reality have risk-value constructions that do not reflect environmental and societal values beyond the framing of waste as a hazard to be managed. Even then, this risk-value is most often underpinned by legislation. Addressing such risks and capturing value to society and the environment in closing material loops then suggests a role for governments as well as business.

\section{Discussion}

Our comparison of the three case studies highlights some of the key factors that influence loop closure. Firstly, we observed that industrial actors are more prone to realize the value of closing REE loops when they operate at adjoining segments, as they already have a transaction established, such as on the case of REE-metal pre-consumer recycling. This is opposed to post-consumer recycling where the relevant transactions span longer communicational distances between a myriad of actors, such as from a consumer and its EoL product, e.g., a REE-phosphor containing lamp, to collecting it and risk-value constructions by all the actors that affect whether the material is permanently stored/landfilled or sent for reprocessing of its material content.

\subsection{Governance Structures}

We observed distinct patterns around the influence of governance structures. It appeared that hierarchy governance is not conducive to closing REE loops, especially when the alternative route to REE-product accessibility is through a market governance structure. This was the case both for the conceptualized centralized facility, the tolling station, and for the EoL REE-phosphor containing powder recycling through chemical separation. The extensive need for information in post-consumer recycling gives rise to a hierarchy governance structure that impedes the closure of REE loops. When, diverging and unstable risk-value constructions emerge among actors involved at the particular segments in combination with hierarchical governance structures in transactions of data and information, disincentives result. Alternatives to hierarchy are required in which the involvement of the actors to the transaction is more balanced.

In contrast, where the supplier-buyer relationship appears modular in the conventional transaction between the metal producing supplier and the metal alloy buying magnet manufacturer, a relational governance structure formed at the pre-consumer recycling stage as the buyer of the metal alloy for magnet enters into a transaction of data and information with the supplier of the alloy. This case of the metal-magnet transaction showed how value was perceived and a stable risk relationship constructed by the relevant actors at these segments so that pre-consumer recycling could take effect. Here, supply of scrap material exists and demand is constructed by making a compelling case of a risk relationship upon which buyer and supplier agree.

Please refer to Table 4 for a summary of the mapped relationships of risk discussed in this paper. 


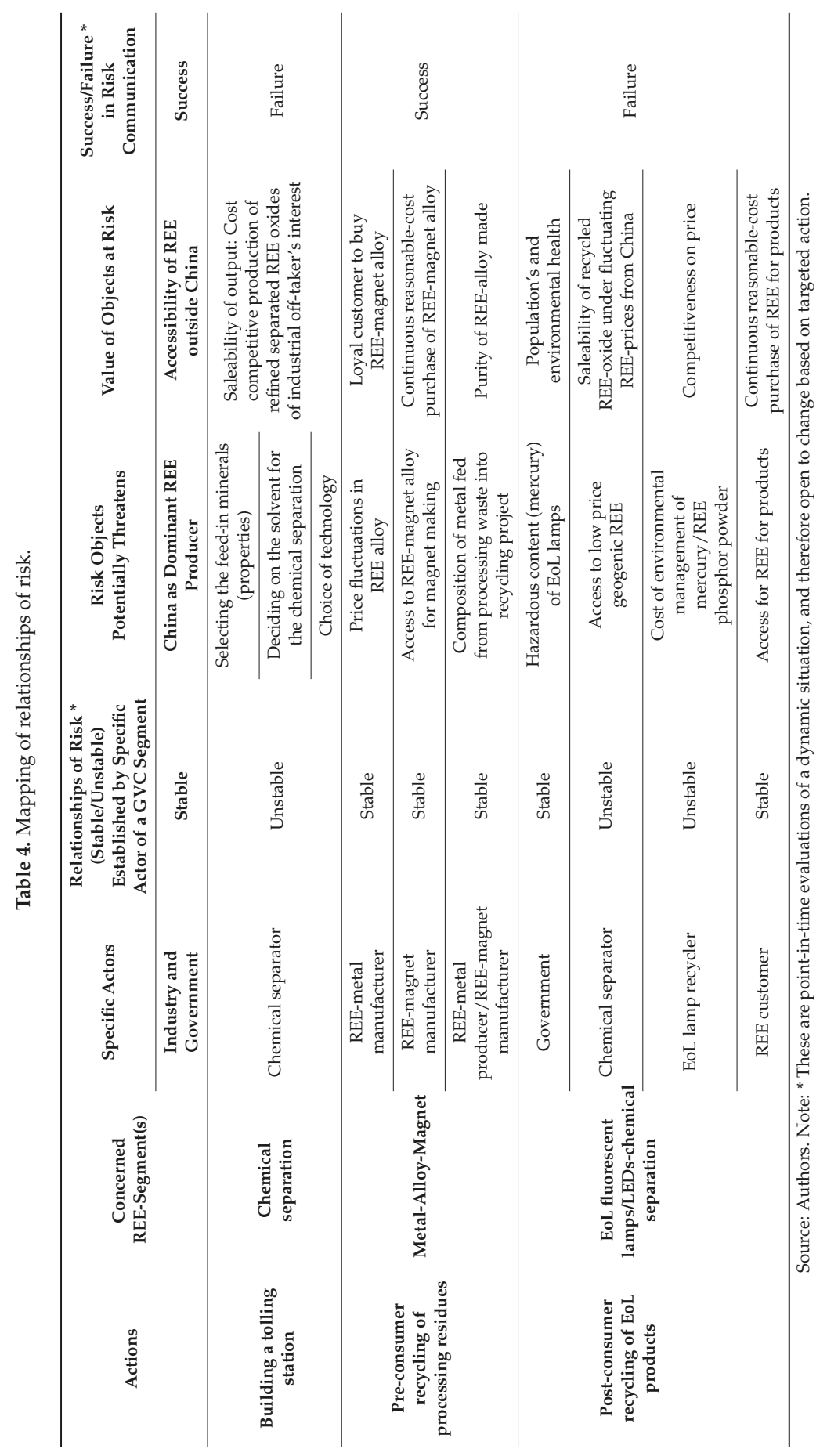


From that case, new roles emerge that challenge the conceptualization of GVC governance structures [31]: The metal buying magnet manufacturer becomes a magnet scrap metal supplier to the metal maker. The latter, however, does not turn into a buyer, but simply a service providing supplier. This speaks to the different dynamics in anthropogenic material flows [53], namely that supply does not follow demand but exists where the scrap material emerges from processing. An interaction between the buyer and supplier is needed to initiate a transaction of data and information to rethink their existing supply-buy relationship for closing the loop by pre-consumer recycling. This is an explicit call for the scholarly and research community to conceptualize in a systematic way the patterns observed in both existing and new empirically evidenced supplier-buyer-service provider relationships. This paper thus points to the limits of the way GVC governance structures are currently conceived of in the literature as framed around one transactional stage rather than two. The first set of transactions involves data and information which provide the foundation for the second transaction of materials or services based on price and accompanying information if required.

\subsection{Risk-Value Constructions}

The risk-value construction of private sector actors (i.e., the industrial actors) diverges significantly from that of public sector actors (i.e., government agencies) as each has different agendas and motivations. Private actors are concerned with the interests of equity holding individuals of a private firm or of shareholding investors of a stock market listed firm operating at the local-regional-global scale. Public actors are motivated to safeguard the interests of nation-wide economic development while ensuring the protection of environmental and human health for the well-being of citizens who are embedded in a global economy. It should not be assumed that either actor will protect the other's values unless a stable risk-value construction is formed between them.

\subsection{Role of Government}

This motivational discrepancy arising from diverging risk-value constructions that seemingly impede the closure of loops supports the argument of Hagelüken [26] that in times of low raw material prices, including of the REE, it is the role of the government to engage with strong leadership and bring measures into place that frame the risk-value construction so that the closure of loops is incentivized. This has been observed in initiatives for other forms of materials recycling. In a study of urban stormwater recycling initiatives, Lane et al. [108] highlighted this need for top down approaches to risk allocation while pointing to significance of clarity around the definition of risk and allocation of risk management responsibilities. Porter and Kramer [68] have pointed to the need for a constructive policy design by government that enables industry to be innovative and find solutions to reaching legislative targets including for recycling. Further accounting for some of the complexities highlighted by the risk-value constructions along GVCs, we argue that the role of government is to "bridge" the risk-value conceptualizations among actors at the pre- and, specifically, post-consumer recycling segments by means of facilitating the flow of information. This should incentivize a transition from a hierarchy governance structure to a relational or modular governance structure in which information is more easily available and codifiable. Possible approaches could include the elaboration of international standards, imprinting barcodes on components that indicate their materials and, as in the EoL lamp case, through legislation. On the latter, Binnemans [36] noted the necessity of fine-tuning regulations to delineate the importance of the minor metals including of REEs, where currently weight percentages cast a shadow over these.

With a view to standards, work on the elaboration of international product and process standards for REE is already in its early stages under the ISO/Technical Committee 298 [109] since late 2016. The drafting of standards is thematically divided into rare earth terms and definitions (minerals, oxides and other compounds in part 1, and rare earth metals and their alloys, in part 2), as well as into rare earth elements recycling (communication formats for providing recycling information on rare earth elements in by-products and industrial wastes; measurement method of REE in by-products 
and industrial wastes; method for the exchange of information of REE in by-products and industrial wastes). This paper speaks to the communication formats and methods for the exchange of information that facilitate recycling.

The bar-coding option is likely to be accompanied with numerous policy-regulatory challenges, in particular with a view to the protection of the intellectual property rights of firms. Rather than prescribing a particular way of bar-coding, policy-discussions may need to center on how the information is to accompany the material in the best possible way. While we note the challenges attached to this option, we encourage industry and policy-makers to jointly discuss and find suitable approaches.

\section{Conclusions}

A transition to a Circular Economy involves identifying and addressing barriers to loop closure, particularly for critical materials such as REE. In this paper, we argue that it is essential to gain an understanding of the transactional dynamics of data and information between a buyer and a supplier in which governance forms arise and risk-value constructions are made that precede pricing and material or service transactions. This supports explanations of how (segments of) rather complex material loops are currently closed or how they might be. Through a focus on REE, we draw attention to how key critical minerals are framed in these discourses, which are complex due to their geological occurrence, processing specifics and industrial uses.

We bring the relational theory of risk into conversation with the governance structures of the GVC framework to assess existing governance structures and explore how risk-value relationships are constructed by the various actors that have interests at specific GVC segments, with implications for why REE loops are closed or not. We observed different governance structures for closing material loops at the pre- and post-consumer recycling stages, with some more likely to enable loop closure than others. Such findings give relevant background information for policymakers and researchers further investigating policy measures to support closing loops.

By drawing on the relational theory of risk, which understands value and risk as intrinsically linked, we take a constructivist angle. The risk-value construction depends on what type of value is being considered and who is assessing it, i.e., the perspective of the actor. A broader notion of value that includes environmental and social values as well as economic ones highlights the difficulty in weighing and assessing value objectively. A clear starting point for policymakers pursing circular economy aims of closing material loops is to identify what values are perceived, and by whom. From the delineated governance forms of the empirical cases, we argue that the government needs to play a pivotal role in closing material loops when the risk-value construction of industrial actors is at odds with the societal values such as public and environmental health which governments are obliged to protect. The role of government, arguably, is to put measures into place that augment transparency of material qualities at a given segment to facilitate data and information availability for transactions, and, thus, foster the formation of closed loops. Along these lines, we recommended specific measures such as the elaboration of standards to qualify materials for re-entry into material processing, which could then be communicated through bar-coding of materials. These measures could be accompanied by appropriate regulatory amendments.

Finally, we encourage more empirical scholarship that systematically maps transactions and reveals governance forms in which risk-value constructions occur that affect loop closure, a significant element of the circular economy. While we have suggested roles for government and policy approaches to address specific issues, further research with a focus on these issues specifically is still needed. With this paper, we hope to initiate a lively, interdisciplinary discourse on this subject and invite scholars with cross-cutting research interests to participate. 
Acknowledgments: The authors gratefully acknowledge the technical assistance with Figure 5 by Susanne Rømer, GEUS. Erika Machacek gratefully acknowledges the Geocenter Denmark (Grant 04/2012) for funding the research which stimulated ideas for this article. Jessika Luth Richter and Ruth Lane have not received specific funding for this article. The funds for covering the costs to publish in open access are covered jointly by the institutions of all contributing authors.

Author Contributions: E.M. conceived the idea for this paper, and, in collaboration with J.L.R. and R.L., designed the analytical framework; E.M. collected and analyzed data for the chemical separation and the metal and magnet loop closure cases; J.L.R. collected and analyzed data for the EoL lamp case; R.L. contributed with literature, comments and supervision; all three authors participated in several rounds of conceptual discussions; and E.M. and J.L.R. wrote the paper.

Conflicts of Interest: The authors declare no conflict of interest.

\section{References}

1. Allwood, J.M.; Ashby, M.F.; Gutowski, T.G.; Worrell, E. Material efficiency: A white paper. Resour. Conserv. Recycl. 2011, 55, 362-381. [CrossRef]

2. Prior, T.; Giurco, D.; Mudd, G.; Mason, L.; Behrisch, J. Resource depletion, peak minerals and the implications for sustainable resource management. Glob. Environ. Chang. 2012, 22, 577-587. [CrossRef]

3. Grædel, T.E.; Harper, E.M.; Nassar, N.T.; Reck, B.K. On the materials basis of modern society. Proc. Natl. Acad. Sci. USA 2015, 112, 6295-6300. [CrossRef] [PubMed]

4. Pearce, D.W.; Turner, R.K. Economics of Natural Resources and the Environment; Harvester Wheatsheaf: London, UK, 1990.

5. McDonough, W.; Braungart, M. Towards a Sustaining Architecture for the 21st Century: The Promise of Cradle-to-Cradle Design. UNEP Indus. Environ. 2003, 26, 13-16.

6. Meadows, D.H. Thinking in Systems; Chelsea Green Publishing: London, UK, 2008; 218p.

7. Stahel, W.R.; Reday, G. The Potential for Substituting Manpower for Energy, Report to the Commission of the European Communities; European Commission: Brussels, Belgium, 1976.

8. Bocken, N.M.P.; Olivetti, E.A.; Cullen, J.M.; Potting, J.; Lifset, R. Taking the Circularity to the Next Level: A Special Issue on the Circular Economy. J. Ind. Ecol. 2017, 21, 476-482. [CrossRef]

9. Geissdoerfer, M.; Savaget, P.; Bocken, N.M.P.; Hultink, E.J. The Circular Economy-A new sustainability paradigm? J. Clean. Prod. 2017, 143, 757-768. [CrossRef]

10. Gregson, N.; Crang, M.; Fuller, S.; Holmes, H. Interrogating the circular economy: The moral economy of resource recovery in the EU. Econ. Soc. 2015, 44, 218-243. [CrossRef]

11. Ellen MacArthur Foundation. Towards the Circular Economy Vol. 1: An economic and business rationale for an accelerated transition. 2012. Available online: https:/ /www.ellenmacarthurfoundation.org/publications/ towards-the-circular-economy-vol-1-an-economic-and-business-rationale-for-an-accelerated-transition (accessed on 5 May 2017).

12. McKinsey and Company. Moving toward a Circular Economy. 2014. Available online: https:/ /www.mckinsey.com/business-functions/sustainability-and-resource-productivity/our-insights / moving-toward-a-circular-economy (accessed on 31 July 2017).

13. European Commission. Growth. Industry. Sustainability and Circular Economy. Circular Economy. 2017. Available online: https:/ / ec.europa.eu/growth/industry/sustainability/circular-economy_en (accessed on 22 October 2017).

14. Gaustad, G.; Krystofik, M.; Bustamante, M.; Badami, K. Circular economy strategies for mitigating critical material supply issues. Resour. Conserv. Recycl. 2017, in press. [CrossRef]

15. EC (2017b) European Commission. Environment. Circular Economy. Implementation of the Circular Economy Action Plan. Available online: http:/ / ec.europa.eu (accessed on 31 July 2017).

16. European Commission. Critical Raw Materials for the EU-Report of the Ad-Hoc Working Group on Defining Critical Raw Materials; EC: Brussels, Belgium, 2010.

17. US DOE. Critical Materials Strategy; US DOE: Washington, DC, USA, 2011.

18. Peck, D.; Kandachar, P.; Tempelman, E. Critical materials from a product design perspective. Mater. Des. (1980-2015) 2015, 65, 147-159. [CrossRef]

19. European Commission. Report on Critical Raw Materials for the EU-Report of the Ad-Hoc Working Group on Defining Critical Raw Materials; EC: Brussels, Belgium, 2014. 
20. ERECON. Strengthening the European Rare Earths Supply Chain: Challenges and Policy Options; Kooroshy, J., Tiess, G., Tukker, A., Walton, A., Eds.; ERECON: Brussels, Belgium, 2014; Available online: http:/ / reinhardbuetikofer.eu/ wp-content/uploads/2015/03/ERECON_Report_v05.pdf (accessed on 31 July 2017).

21. MSP-REFRAM. Multi-Stakeholder Platform for a Secure Supply of Refractory Metals in Europe. 2017. Available online: http://cordis.europa.eu/project/rcn/199884_en.html (accessed on 18 July 2017).

22. Ghisellini, P.; Cialani, C.; Ulgiati, S. A review on circular economy: The expected transition to a balanced interplay of environmental and economic systems. J. Clean. Prod. 2016, 114, 11-32. [CrossRef]

23. Moreau, V.; Sahakian, M.; van Griethuysen, P.; Vuille, F. Coming Full Circle: Why Social and Institutional Dimensions Matter for the Circular Economy. J. Ind. Ecol. 2017, 21, 497-506. [CrossRef]

24. Reck, B.K.; Graedel, T.E. Challenges in Metal Recycling. Science 2012, 337, 690-695. [CrossRef] [PubMed]

25. UNEP. Metal Recycling: Opportunities, Limits, Infrastructure. A Report of the Working Group on the Global Metal Flows to the International Resource Panel; Reuter, M.A., Hudson, C., van Schaik, A., Heiskanen, K., Meskers, C., Hagelüken, C., Eds.; UNEP: Nairobi, Kenya, 2013; ISBN 978-92-807-3267-2.

26. Hagelüken, C. Bedeutung des EU Kreislaufwirtschaftspakets für das Metallrecycling. Chem. Ing. Tech. 2017, 89, 17-28. [CrossRef]

27. Coe, N.; Dicken, P.; Hess, M. Global Production Networks: Realizing the Potential. J. Econ. Geogr. 2008, 8, 271-295. [CrossRef]

28. Blomsma, F.; Brennan, G. The Emergence of Circular Economy: A New Framing Around Prolonging Resource Productivity: The Emergence of Circular Economy. J. Ind. Ecol. 2017, 21, 603-614. [CrossRef]

29. Santos, D.; Lane, R. A material lens on socio-technical transitions: The case of steel in Australian buildings. Geoforum 2017, 82, 40-50. [CrossRef]

30. Lepawsky, J.; Billah, M. Making chains that (un)make things: Waste-value relations and the Bangladeshi rubbish electronics industry. Geografiska Annaler Ser. B 2011, 93, 121-139. [CrossRef]

31. Gereffi, G.; Humphrey, J.; Sturgeon, T. The governance of global value chains. Rev. Int. Political Econ. 2005, 12, 78-104. [CrossRef]

32. Boholm, Å.; Corvellec, H. A relational theory of risk. J. Risk Res. 2011, 14, 175-190. [CrossRef]

33. Machacek, E.; Fold, N. Alternative value chains for rare earths: The Anglo-deposit developers. Res. Pol. 2014, 42, 53-64. [CrossRef]

34. Balomenos, E. Points for discussion: A roadmap for the European REE industry. In Proceedings of the 2nd Conference on European Rare Earth Resources (ERES2017), Santorini, Greece, 28-31 May 2017.

35. Binnemans, K.; Jones, P.T.; Acker, K.; Blanpain, B.; Mishra, B.; Apelian, D. Rare-Earth Economics: The Balance Problem. JOM 2013, 65, 846-848. [CrossRef]

36. Binnemans, K. Policy Brief EREAN, REDMUD and DEMETER: Importance of Training and Research to the Supply of Critical Raw Materials in Europe; KU Leuven: Leuven, Belgium, 2016; p. 12.

37. Binnemans, K.; Jones, P.T.; Blanpain, B.; Van Gerven, T.; Yang, Y.; Walton, A.; Buchert, M. Recycling of rare earths: A critical review. J. Clean. Prod. 2013, 51, 1-22. [CrossRef]

38. Machacek, E.; Richter, J.L.; Habib, K.; Klossek, P. Recycling of rare earths from fluorescent lamps: Value analysis of closing-the-loop under demand and supply uncertainties. Resour. Conserv. Recycl. 2015, 104, 76-93. [CrossRef]

39. Mueller, S.R.; Wäger, P.A.; Widmer, R.; Williams, I.D. A geological reconnaissance of electrical and electronic waste as a source for rare earth metals. Waste Manag. 2015, 45, 226-234. [CrossRef] [PubMed]

40. Eggert, R.; Wadia, C.; Anderson, C.; Bauer, D.; Fields, F.; Meinert, L.; Taylor, P. Rare Earths: Market Disruption, Innovation, and Global Supply Chains. Annu. Rev. Environ. Resour. 2016, 41, 199-222. [CrossRef]

41. Binnemans, K.; Jones, P.T.; Blanpain, B.; Van Gerven, T.; Pontikes, Y. Towards zero-waste valorisation of rare-earth containing industrial process residues: A critical review. J. Clean. Prod. 2015, 99, 17-38. [CrossRef]

42. Rademaker, J.H.; Kleijn, R.; Yang, Y. Recycling as a Strategy against Rare Earth Element Criticality: A Systemic Evaluation of the Potential Yield of NdFeB Magnet Recycling. Environ. Sci. Technol. 2013, 47, 10129-10136. [CrossRef] [PubMed]

43. Lane, R. Understanding the Dynamic Character of Value in Recycling Metals from Australia. Resources 2014, 3, 416-431. [CrossRef]

44. Mueller, S.R.; Wäger, P.A.; Turner, D.A.; Shaw, P.J.; Williams, I.D. A framework for evaluating the accessibility of raw materials from end-of-life products and the Earth's crust. Waste Manag. 2017, 68, 534-546. [CrossRef] [PubMed] 
45. Richter, J.L. The complexity of value: Considerations for WEEE, experience from lighting products, and implications for policy. In Proceedings of the Electronics Goes Green 2016+ Conference, Berlin, Germany, 6-9 September 2016.

46. Richter, J.L. Extended Producer Responsibility for Closing Material Loops. Lessons from Energy-Efficient Lighting Products. Ph.D. Thesis, Licentiate Dissertation. IIIEE, Lund University, Lund, Sweden, 2016.

47. Richter, J.L.; Koppejan, R. Extended producer responsibility for lamps in Nordic countries: Best practices and challenges in closing material loops. J. Clean. Prod. 2016, 123, 167-179. [CrossRef]

48. Pauliuk, S.; Majeau-Bettez, G.; Müller, D.B. A General System Structure and Accounting Framework for Socioeconomic Metabolism. J. Ind. Ecol. 2015, 20, 728-741. [CrossRef]

49. Giljum, S.; Hubacek, K. Conceptual Foundations and Applications of Physical Input-Output Tables. In Handbook of Input-Output Economics in Industrial Ecology; Giljum, S., Hubacek, K., Tukker, A., Sangwon, S., Eds.; Springer: Dordrecht, The Netherlands, 2009; 882p.

50. Brunner, P.H.; Rechberger, H. Practical Handbook of Material Flow Analysis. 2004. Available online: http://iwr.tuwien.ac.at/fileadmin/mediapool-ressourcen/MFA_Handbook/solutions.pdf (accessed on 28 July 2017).

51. Bair, J. Global Capitalism and Commodity Chains: Looking Back, Going Forward. Compet. Chang. 2005, 9, 153-180. [CrossRef]

52. Lepawsky, J. The changing geography of global trade in electronic discards: Time to rethink the e-waste problem. Geogr. J. 2015, 181, 147-159. [CrossRef]

53. Ponte, S.; Sturgeon, T. Explaining governance in global value chains: A modular theory-building effort. Rev. Int. Political Econ. 2014, 21, 195-223. [CrossRef]

54. Crang, M.A.; Hughes, A.; Gregson, N.; Norris, L.; Ahamed, F.U. Rethinking governance and value in commodity chains through global recycling networks. TIBG 2013, 38, 12-24. [CrossRef]

55. Humphrey, J.; Schmitz, H. Governance in Global Value Chains. IDS Bull. 2001, 32, 19-29. [CrossRef]

56. Hilgartner, S. The Social Construction of Risk Objects: Or, How to Pry Open Networks of Risk. Organizations, Uncertainties, and Risk; Westview Press: Boulder, CO, USA, 1992.

57. Rescher, N. Risk: A Philosophical Introduction to the Theory of Risk Evaluation and Management; University Press of America: Lanham, MD, USA, 1983.

58. Rosa, E. Metatheoretical foundations for post-normal risk. J. Risk Res. 1998, 1, 15-44. [CrossRef]

59. Boholm, A. The cultural nature of risk: Can there be an anthropology of uncertainty? Ethnos J. Anthropol. 2003, 68, 159-179. [CrossRef]

60. Corvellec, H. Organizational risk as it derives from what managers value: A practice-based approach to risk assessment. J. Conting. Crisis Manag. 2010, 18, 145-154. [CrossRef]

61. Renn, O. Risk Governance: Coping with Uncertainty in a Complex World; Earthscan: London, UK, 2008.

62. Luhmann, N. The Cognitive Program of Constructivism and a Reality that Remains Unknown. In Selforganization; Sociology of the Sciences Book Series; Springer: Dordrecht, The Netherlands, 1990; Volume 14, pp. 64-85.

63. Howes, M. Chapter 2: The origins of risk and modern governance. In Politics and the Environment: Risk and the Role of Government and Industry; Allen \& Unwin: Sydney, Australia, 2005; pp. 25-39.

64. Bocken, N.; Short, S.; Rana, P.; Evans, S. A value mapping tool for sustainable business modelling. Corp. Gov. 2013, 13, 482-497. [CrossRef]

65. Dalhammar, C. The Setting of Ecodesign Standards to Promote Improved Waste Recycling. Conference Paper. 2014. Available online: https://www.jstage.jst.go.jp/article/jsmcwm/25/0/25_605/_pdf (accessed on 27 July 2017).

66. Tojo, N.; Lindhqvist, T.; Dalhammar, C. Extended producer responsibility as a driver for product chain improvements. In Governance of Integrated Product Policy: In Search of Sustainable Production and Consumption; Scheer, D., Rubik, F., Eds.; Greenleaf Publishing: London, UK, 2006.

67. Lindhqvist, T. Extended Producer Responsibility in Cleaner Production. Ph.D. Thesis, IIIEE Dissertations. IIIEE, Lund University, Lund, Sweden, 2000.

68. Porter, M.E.; Kramer, M.R. Creating shared value. Harv. Bus. Rev. 2011, 89, 62-77.

69. Gereffi, G.; Korzeniewicz, M. Commodity Chains and Global Capitalism; Præger: Westport, CT, USA, 1994.

70. Porter, M.E. Competitive Advantage: Creating and Sustaining Superior Performance; The Free Press: New York, NY, USA, 1985. 
71. Crane, A.; Palazzo, G.; Spence, L.J.; Matten, D. Contesting the Value of 'Creating Shared Value'. Calif. Manag. Rev. 2014, 56, 130-153. [CrossRef]

72. Hultman, J.; Corvellec, H. The European Waste Hierarchy: From the Sociomateriality of Waste to a Politics of Consumption. Environ. Plan. A 2012, 44, 2413-2427. [CrossRef]

73. Van Loon, J. Risk and Technological Culture: Towards a Sociology of Virulence; Routledge: London, UK, 2002.

74. Wenger, E. Communities of practice: Learning as a Social System. Systems Thinker, 1998. Available online: https:/ / moo27pilot.eduhk.hk/ (accessed on 14 June 2017).

75. Nicolini, D.; Gherardi, S.; Yanow, D. Introduction: Toward a Practice-Based View of Knowing and Learning in Organizations. In Knowing in Organizations: A Practice-based Approach; Nicolini, D., Gherardi, S., Yanow, D., Eds.; M.E. Sharpe: Armonk, NY, USA; London, UK, 2003.

76. Savigny, E.; Knorr-Cetina, K.; Schatzki, T.R. The Practice Turn in Contemporary Theory; Routledge: London, UK, 2001.

77. EREAN. EU FP7 Marie-Curie Initial Training Network. 2017. Available online: erean.eu (accessed on 31 July 2017).

78. NERC. EURARE Project. Development of a Sustainable Exploitation Scheme for Europe's Rare Earth Ore Deposits; Machacek, E., Kalvig, P., Eds.; Market Report; European Commission: Brussels, Belgium, 2017. Available online: www.eurare.eu/docs/T1.1.2_Report-final-280217.pdf (accessed on 28 July 2017).

79. Balomenos, E.; Davris, P.; Deady, E.; Yang, J.; Panias, D.; Friedrich, B.; Binnemans, K.; Seisenbaeva, G.; Dittrich, C.; Kalvig, P.; et al. The EURARE Project: Development of a Sustainable Exploitation Scheme for Europe's Rare Earth Ore Deposits. Johns. Matthey Technol. Rev. 2017, 61, 142. [CrossRef]

80. REE4EU. Rare Earth Recycling for Europe. 2017. Available online: www.ree4eu.eu (accessed on 28 July 2017).

81. REEcover. Recovery of Rare Earth Elements from Magnetic Waste in the WEEE Recycling Industry and Tailings from the Iron Ore Industry. 2015. Available online: www.reecover.eu (accessed on 28 July 2017).

82. REMANENCE. Rare Earth Magnet Recovery for Environmental \& Resource Protection. 2017. Available online: www.project-remanence.eu (accessed on 28 July 2017).

83. Bast, U. Recycling von Komponenten und strategischen Metallen aus elektrischen Fahrantrieben: MORE (Motor Recycling). Final Research Report. 2014. Available online: http://edok01.tib.uni-hannover.de/ edoks/e01fb15/826920594.pdf (accessed on 8 May 2016).

84. Walachowicz, F.; March, A.; Fiedler, S.; Buchert, M.; Sutte, J.; Merz, C. Recycling von Elektromotoren-MORE: Oekobilanz der Recyclingverfahren. Final Report, Berlin. 2014. Available online: http://de.slideshare.net/ AndrewMarch/morelcaendberichtfinal17okt2014 (accessed on 8 May 2016).

85. Tanaka, M.; Oki, T.; Koyama, K.; Narita, H.; Oishi, T. Recycling of rare earths from scrap. In Handbook on the Physics and Chemistry of Rare Earths; Jean-Claude, G.B., Vitalij, K.P., Eds.; Elsevier: Amsterdam, The Netherlands, 2013.

86. Takeda, O.; Okabe, T.H. Current status on resource and recycling technology for rare earths. Metall. Mater. Trans. E 2014, 1, 160-173. [CrossRef]

87. Yang, Y.; Walton, A.; Sheridan, R.; Güth, K.; Gauss, R.; Gutfleisch, O.; Buchert, M.; Steenari, B.-M.; Van Gerven, T.; Jones, P.T.; et al. REE Recovery from End-of-Life NdFeB Permanent Magnet Scrap: A Critical Review. J. Sustain. Metall. 2017, 3, 122-149. [CrossRef]

88. Bandara, H.M.D.; Darcy, J.W.; Apelian, D.; Emmert, M.H. Value analysis of neodymium content in shredder feed: Towards enabling the feasibility of rare earth magnet recycling. Environ. Sci. Technol. 2014, 48, 6553-6560. [CrossRef] [PubMed]

89. Firdaus, M.; Rhamdhani, M.A.; Durandet, Y.; Rankin, W.J.; McGregor, K. Review of high-temperature recovery of rare earth (Nd/Dy) from magnet waste. J. Sustain. Metall. 2016, 2, 276-295. [CrossRef]

90. Leveque, A. Extraction and separation of rare earths. Presented at the Summer School on Rare Earth Technologies, Leuven University, Leuven, Belgium, 12 August 2014.

91. Hatch, G.P. Recent Dynamics in the Global Rare-Earths Market. In Proceedings of the Magnetic Materials in Electrical Machine Applications, Pori, Finland, 13-15 June 2012.

92. Paulick, H.; Machacek, E. The global rare earth element exploration boom: An analysis of resources outside of China and discussion of development perspectives. Res. Pol. 2017, 52, 134-153. [CrossRef]

93. Golev, A.; Scott, M.; Erskine, P.D.; Ali, S.H.; Ballantyne, G.R. Rare earth supply chains: Current status, constraints and opportunities. Res. Pol. 2014, 41, 52-59. [CrossRef] 
94. Respondent A (Metal producer, Ellesmere Port, UK). Personal conversation, 2017.

95. Respondent B (Metal producer, Ellesmere Port, UK). Personal conversation, 2017.

96. Interview A (Head of R\&D, Relight Italia). Personal conversation, 2017.

97. Interview B (Sales group manager for Ekokem Corporation, Finland). Personal communication, 2015.

98. Interview C (Rare Earth Consultant, formerly Solvay Technology Development Manager, Leuven, Belgium). Personal communication, 2017.

99. Ali, S.H. Social and Environmental Impact of the Rare Earth Industries. Resources 2014, 3, 123-134. [CrossRef]

100. Haque, N.; Hughes, A.; Lim, S.; Vernon, C. Rare Earth Elements: Overview of Mining, Mineralogy, Uses, Sustainability and Environmental Impact. Resources 2014, 3, 614-635. [CrossRef]

101. Leal Filho, W. Chapter 17-An Analysis of the Environmental Impacts of the Exploitation of Rare Earth Metals. In Rare Earths Industry; Elsevier: Boston, MA, USA, 2016; pp. 269-277.

102. Lee, J.C.K.; Wen, Z. Rare Earths from Mines to Metals: Comparing Environmental Impacts from China's Main Production Pathways. J. Ind. Ecol. 2016. [CrossRef]

103. Packey, D.J.; Kingsnorth, D. The impact of unregulated ionic clay rare earth mining in China. Res. Pol. 2016, 48, 112-116. [CrossRef]

104. Vahidi, E.; Navarro, J.; Zhao, F. An initial life cycle assessment of rare earth oxides production from ion-adsorption clays. Resour. Conserv. Recycl. 2016, 113, 1-11. [CrossRef]

105. Walter, P. Rhodia recovers rare earths. Chemistry \& Industry. 7 February 2011, p. 6. Available online: http: //www.soci.org/Chemistry-and-Industry/CnI-Data/2011/3/Rhodia-recovers-rare-earths (accessed on 20 June 2017).

106. Solvay. Layman's Report-Projekt «LOOP»LIFE11/ENV/FR/00744. 2014. Available online: http://www. solvay.com/en/binaries/Solvay\%20Loop\%20De_En\%20NUM-197436.pdf (accessed on 14 July 2017).

107. Leoty, X. La Rochelle: Fermeture de l'atelier de recyclage des terres rares de Solvay d'ici fin 2016. SudOuest, 15 January 2016. Available online: http:/ / www.sudouest.fr (accessed on 15 July 2017).

108. Lane, R.; Bettini, Y.; McCallum, T.; Head, B.W. The interaction of risk allocation and governance arrangements in innovative urban stormwater and recycling projects. Landsc. Urban Plan. 2017, 164, 37-48. [CrossRef]

109. Standardization Administration of China. Rare earth. ISO/TC 298. Available online: https://www.iso.org (accessed on 25 July 2017).

(C) 2017 by the authors. Licensee MDPI, Basel, Switzerland. This article is an open access article distributed under the terms and conditions of the Creative Commons Attribution (CC BY) license (http:/ / creativecommons.org/licenses/by/4.0/). 
MDPI

St. Alban-Anlage 66

4052 Basel

Switzerland

Tel. +41616837734

Fax +41 613028918

www.mdpi.com

Resources Editorial Office

E-mail: resources@mdpi.com

www.mdpi.com/journal/resources

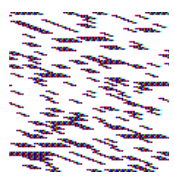



MDPI

St. Alban-Anlage 66

4052 Basel

Switzerland

Tel: +41 616837734

Fax: +41 613028918 